\title{
Evaluating and Ranking Threats to the Long-Term Persistence of Polar Bears
}

Open-File Report 2014-1254

U.S. Department of the Interior

U.S. Geological Survey 
Cover: A family group of polar bears composed of an adult female and two yearlings, along the coast of northern Alaska, autumn 2009. Photograph taken by Mike Lockhart, volunteer with the U.S. Geological Survey's Polar Bear Program. 


\section{Evaluating and Ranking Threats to the Long-Term Persistence of Polar Bears}

By Todd C. Atwood, Bruce G. Marcot, David C. Douglas, Steven C. Amstrup, Karyn D. Rode, George M. Durner, and Jeffrey F. Bromaghin

Open-File Report 2014-1254

U.S. Department of the Interior

U.S. Geological Survey 


\section{U.S. Department of the Interior \\ SALLY JEWELL, Secretary}

\section{U.S. Geological Survey \\ Suzette M. Kimball, Acting Director}

U.S. Geological Survey, Reston, Virginia: 2015

For more information on the USGS-the Federal source for science about the Earth,

its natural and living resources, natural hazards, and the environment-visit

http://www.usgs.gov or call 1-888-ASK-USGS (1-888-275-8747)

For an overview of USGS information products, including maps, imagery, and publications, visit http://www.usgs.gov/pubprod

To order this and other USGS information products, visit http://store.usgs.gov

Any use of trade, firm, or product names is for descriptive purposes only and does not imply endorsement by the U.S. Government.

Although this information product, for the most part, is in the public domain, it also may contain copyrighted materials as noted in the text. Permission to reproduce copyrighted items must be secured from the copyright owner.

Suggested citation:

Atwood, T.C., Marcot, B.G., Douglas, D.C., Amstrup, S.C., Rode, K.D., Durner, G.M., and Bromaghin, J.F., 2015, Evaluating and ranking threats to the long-term persistence of polar bears: U.S. Geological Survey Open-File Report 2014-1254, 114 p., http://dx.doi.org/10.3133/ofr20141254.

ISSN 2331-1258 (online) 


\section{Contents}

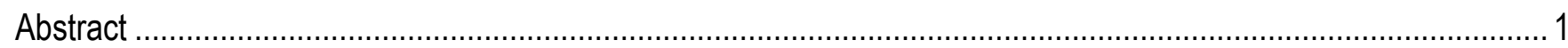

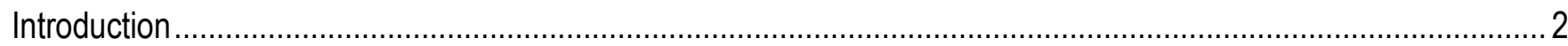

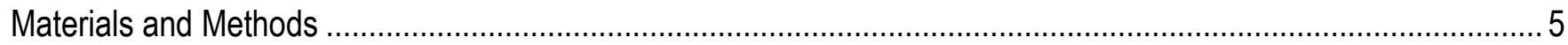

Revision of the First Generation Model .................................................................................................

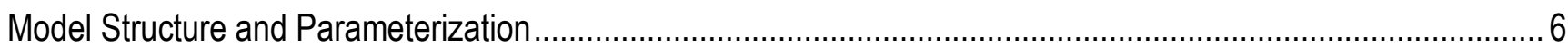

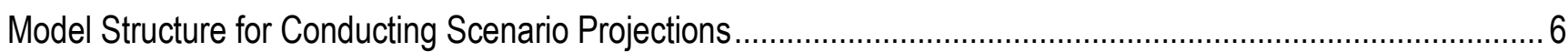

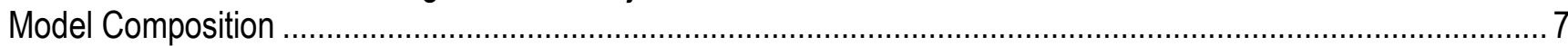

Sensitivity Analysis and Influence Runs ............................................................................................ 14

Comparison of Polar Bear Ecoregion Outcomes under Stabilized and Unabated GHG Emissions Pathways...... 15

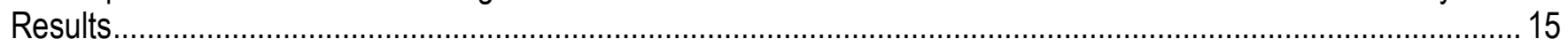

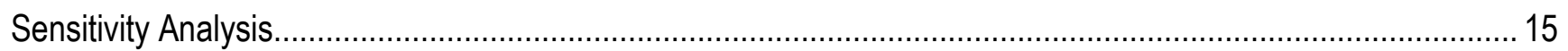

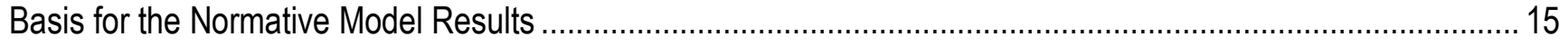

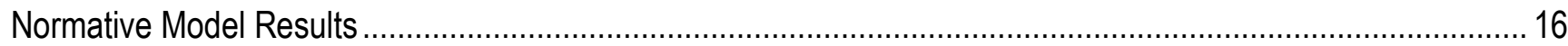

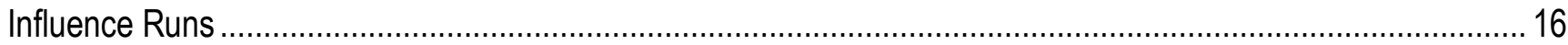

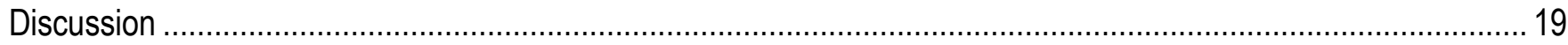

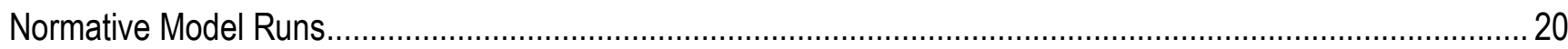

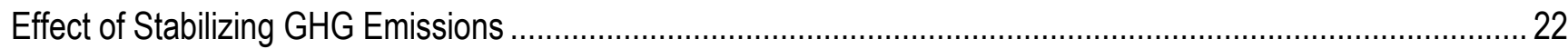

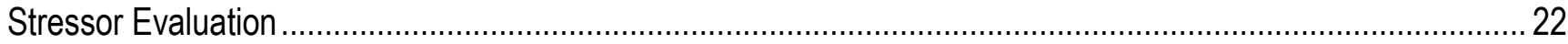

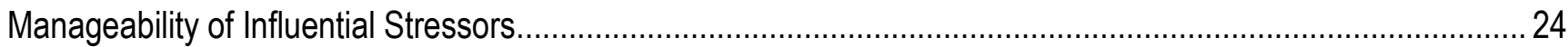

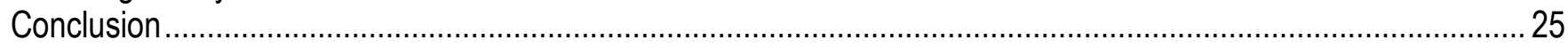

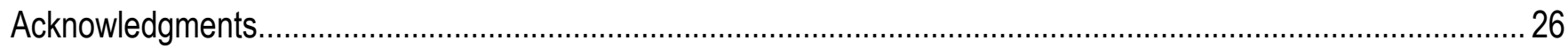

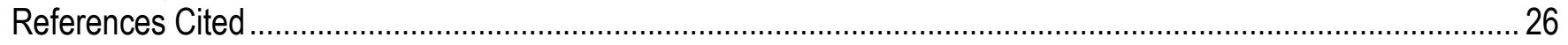

Appendix A. Name, Job Title, Area of Expertise, and Professional Affiliation for Each Subject Matter Expert .........50

Appendix B. Additional Information on the Process Used to Develop and Parameterize the Model.........................51

Appendix C. Description (Including Key Assumptions) of All Nodes in the Second Generation Model......................53

Appendix D. Normative Scenarios (Using Expected Values of Input Conditions) Run on the

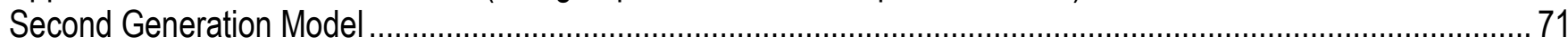

Appendix E. Conditional Probability Tables for Each Summary (i.e., Intermediate) Node in the

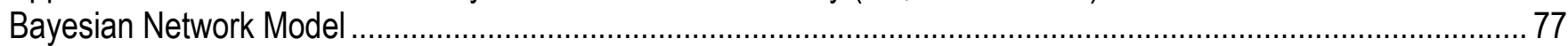

Appendix F. Influence Run Results for RCP 4.5 and 8.5 by Ecoregion ........................................................... 99 


\section{Figures}

Figure 1. Map of the four polar bear ecoregions as defined by Amstrup and others (2008)................................. 36

Figure 2. General structure of the second generation model showing the relationships

among the 10 submodels

Figure 3. The second generation model used to evaluate the relative influence of stressors on future polar bear population outcomes

Figure 4. Changes in sea ice extent as simulated by CMIP5 models over the second half of the 20th century and the entire 21st century under RCP2.6, RCP4.5, RCP6.0, and RCP8.5 for the Northern Hemisphere, September (number of models available for each RCP is given in the explanation). 39

Figure 5. Sensitivity of the final outcome node "relative influence on population trend" to all 24 input (parentless) model nodes.

Figure 6. Polar bear outcomes from the second generation model.

Figure 7. Influence of "overall sea ice conditions" (a, b) and "marine prey base" (c, d) on the probability of a "greatly decreased" outcome for polar bears from the Polar Basin Divergent Ecoregion at four future time periods using RCP 4.5 and 8.5

Figure 8. Influence of "overall sea ice conditions" ( $a, b)$ and "marine prey base" (c, d) on the probability of a "greatly decreased" outcome for polar bears from the Polar Basin Convergent Ecoregion at four future time periods using RCP 4.5 and 8.5 .

Figure 9. Influence of "overall sea ice conditions" (a, b) and "marine prey base" (c, d) on the probability of a "greatly decreased" outcome for polar bears from the Seasonal Ice Ecoregion at four future time periods using RCP 4.5 and 8.5 .

Figure 10. Influence of "overall sea ice conditions" (a, b) and "marine prey base" (c, d) on the probability of a "greatly decreased" outcome for polar bears from the Archipelago Ecoregion at four future time periods using RCP 4.5 and 8.5 .

\section{Table}

Table 1. The 13 general circulation models (GCM) used in this study, and the models' country and institute of origin 


\section{Conversion Factors}

\begin{tabular}{lll}
\hline \multicolumn{1}{c}{ Multiply } & \multicolumn{1}{c}{ By } & \multicolumn{1}{c}{ To obtain } \\
\hline Length & \\
\hline kilometer $(\mathrm{km})$ & 0.6214 & mile $(\mathrm{mi})$ \\
square kilometer & 0.3861 & square mile $\left(\mathrm{mi}^{2}\right)$ \\
meter $(\mathrm{m})$ & 3.281 & foot $(\mathrm{ft})$ \\
meter $(\mathrm{m})$ & 1.094 & yard $(\mathrm{yd})$ \\
\hline
\end{tabular}

\section{Abbreviations, Acronyms, and Symbols}

\begin{tabular}{ll}
\hline \multicolumn{1}{c}{ Abbreviations, Acronyms, and } & \multicolumn{1}{c}{ Meaning } \\
Symbols & Archipelago Ecoregion \\
AE & Bayesian network model \\
CMIP5 & Coupled model intercomparison project phase 5 \\
$\mathrm{CO}_{2}$ & Carbon dioxide \\
CPT & Conditional probability table \\
DLP & Defense of Life and Property \\
ESA & Endangered Species Act \\
GCM & General circulation model \\
GHG & Greenhouse gas \\
NSIDC & National Snow and Ice Data Center \\
PBCE & Polar Basin Convergent Ecoregion \\
PBDE & Polar Basin Divergent Ecoregion \\
RCP & Representative concentration pathway \\
RSF & Resource selection function \\
SIE & Seasonal Ice Ecoregion \\
SRES & Special Report on Emissions Scenarios \\
\hline
\end{tabular}


This page left intentionally blank 


\title{
Evaluating and Ranking Threats to the Long-Term Persistence of Polar Bears
}

\author{
By Todd C. Atwood ${ }^{1}$, Bruce G. Marcot², David C. Douglas', Steven C. Amstrup ${ }^{3}$, Karyn D. Rode 1 , George M. \\ Durner ${ }^{1}$, and Jeffrey F. Bromaghin ${ }^{1}$
}

\begin{abstract}
The polar bear (Ursus maritimus) was listed as a globally threatened species under the U.S. Endangered Species Act (ESA) in 2008, mostly due to the significant threat to their future population viability from rapidly declining Arctic sea ice. A core mandate of the ESA is the development of a recovery plan that identifies steps to maintain viable populations of a listed species. A substantive evaluation of the relative influence of putative threats to population persistence is helpful to recovery planning. Because management actions must often be taken in the face of substantial information gaps, a formalized evaluation hypothesizing potential stressors and their relationships with population persistence can improve identification of relevant conservation actions. To this end, we updated a Bayesian network model previously used to forecast the future status of polar bears worldwide. We used new information on actual and predicted sea ice loss and polar bear responses to evaluate the relative influence of plausible threats and their mitigation through management actions on the persistence of polar bears in four ecoregions. We found that polar bear outcomes worsened over time through the end of the century under both stabilized and unabated greenhouse gas (GHG) emission pathways. Under the unabated pathway (i.e., RCP 8.5), the time it took for polar bear populations in two of four ecoregions to reach a dominant probability of greatly decreased was hastened by about 25 years. Under the stabilized GHG emission pathway (i.e., RCP 4.5), where GHG emissions peak around the year 2040, the polar bear population in the Archipelago Ecoregion of High Arctic Canada never reached a dominant probability of greatly decreased, reinforcing earlier suggestions of this ecoregion's potential to serve as a long-term refugium. The most influential drivers of adverse polar bear outcomes were declines to overall sea ice conditions and to the marine prey base. Improved sea ice conditions substantively lowered the probability of a decreased or greatly decreased outcome, while an elevated marine prey base was slightly less influential in lowering the probability of a decreased or greatly decreased outcome. Stressors associated with in situ human activities exerted considerably less influence on population outcomes. Reduced mortality from hunting and defense of life and property interactions resulted in
\end{abstract}

\footnotetext{
${ }^{1}$ U.S. Geological Survey.

${ }^{2}$ U.S. Forest Service.

${ }^{3}$ Polar Bears International.
} 
modest declines in the probability of a decreased or greatly decreased population outcome. Minimizing other stressors such as trans-Arctic shipping, oil and gas exploration, and point-source pollution had negligible effects on polar bear outcomes, but that could be attributed to uncertainties in the ecological relevance of those specific stressors. Our findings suggest adverse consequences of loss of sea ice habitat become more pronounced as the summer ice-free period lengthens beyond 4 months, which could occur in portions of the Arctic by the middle of this century under the unabated pathway. The long-term persistence of polar bears may be achieved through ameliorating the loss of sea ice habitat, which will likely require stabilizing $\mathrm{CO}_{2}$ emissions at or below the ceiling represented by RCP 4.5. Management of other stressors may serve to slow the transition of polar bear populations to progressively worsened outcomes, and improve the prospects of persistence, pending GHG mitigation.

\section{Introduction}

The aims of the U.S. Endangered Species Act (ESA) include protecting imperiled species from extinction and recovering and maintaining viable populations by mitigating threats to survival. As a means toward that goal, the ESA requires the development of a recovery plan that contains objective and measurable criteria (i.e., recovery criteria) that address the factors that led to the species being listed as threatened or endangered (16 U.S.C. $\$ 1533$ [f][1][B][ii]). Conceptually, the development of recovery criteria follows a two-step process. The first step requires the identification of stressors (i.e., any environmental or anthropogenic influence that has the potential to exert a positive or negative effect; Bedoya and others, 2011) that are likely to influence population viability, such as changing habitat conditions, certain forms of anthropogenic activity (e.g., pollution, industrial development), overutilization, disease, and inadequacy of existing regulatory mechanisms. The second step is to determine which stressors can be mitigated to achieve a favorable conservation outcome. A critical aspect of this approach is explicitly linking stressors to demographic responses (Clark and others, 2002). This is a challenging task and recovery plans may be aided by a formal evaluation of the relative value that alleviating or mitigating specific stressors may have on recovery goals (Lawler and others, 2002; Schultz and Gerber, 2002).

In 2008, the polar bear (Ursus maritimus) was listed as globally threatened under the ESA. The decision to list polar bears was informed by the body of research suggesting that observed and projected reductions in sea ice habitat as affected by a warming climate, along with other lesser stressors from environmental conditions and anthropogenic activities, collectively, presented a challenge to the persistence of polar bears over the foreseeable future (U.S. Fish and Wildlife Service, 2008). The Arctic marine "ice cap" may have been in place for more than 5 million years (Polyak and others, 2010), and provides critical habitat for 11 ice-adapted marine mammals, including polar bears (Kovacs and others, 2011). Over the last two decades, increased ambient air temperature (Lindsay and Zhang, 2005), advection of warm water into the Arctic Ocean (Shimada and others, 2006), and advection of sea ice out of the Arctic Ocean through Fram Strait (Serreze and others, 2007) have driven a decline in the extent and thickness of first- and multi-year sea ice, particularly in summer (Arrigo and others, 2008; Wang and Overland, 2009; Kovacs and others, 2011). From 2002 to 2013, the extent of summer sea ice decreased at a rate of 14 percent per decade (Stroeve and others, 2014). According to the most recent predictions, the Arctic may be functionally ice-free (i.e., $<1.0 \mathrm{M} \mathrm{km}^{2}$ ) in summer within 10-15 years, and perhaps sooner (Overland and Wang, 2013). The climate-driven changes to the Arctic marine ecosystem generally are believed to be negative for ice-adapted species such as polar bears (e.g., Stirling and Derocher, 1993; Stirling and Derocher, 2012; Derocher and others, 2013). 
Primary foraging habitat for polar bears is annual sea ice that occurs over the biologically productive continental shelf and other shallow water areas (Durner and others, 2009). Sea ice serves as a substrate that provides access to ringed (Phoca hispida) and bearded (Erignathus barbatus) seals, the preferred prey of polar bears (Thiemann and others, 2008). Declines in the extent, connectivity, and temporal availability of sea ice over the shelf equates to a loss of functional habitat (Sahanatien and Derocher, 2012). Indeed, reduced temporal availability of sea ice, which occurs between ice break-up in the spring and freeze-up in the autumn, is perhaps the most pressing concern as it directly constrains foraging opportunities. Throughout the Arctic, the period of reduced ice availability (hereafter referred to as the open water season) has lengthened - there has been a trend toward an earlier mean date of break-up and, in some cases, a trend in later freeze-up (Stroeve and others, 2014). The lengthening open water season has been linked to declines in polar bear body condition (Stirling and others, 1999; Obbard and others, 2006; Rode and others, 2010), reproductive indices (Stirling and Parkinson, 2006), and survival (Regehr and others, 2007). According to energy budget models, a 30-day increase in the length of the open water season could lead to a significant increase in reproductive failure and starvation for some populations (Molnar and others, 2010; Robbins and others, 2012). In portions of the Arctic, the open water season has already increased by 21 days over a 30-year period (Gagnon and Gough, 2005).

Although some polar bear populations have already experienced sea ice loss and measurable negative effects on body condition, reproduction, and survival have been documented, there is geographic variation in the rate and extent of declines in sea ice habitat and population responses. For example, the Davis Strait polar bear population increased during a time period when the duration of seasonal ice declined (Peacock and others, 2013). This effect was largely attributed to an increase in availability of new prey, harp seals (Pagophilus groenlandicus), and polar bear population size is believed to have stabilized in apparent response to density dependent effects after a period of population growth. In the northern Beaufort Sea, sea ice also has declined but thus far the population appears to be stable (Stirling and others, 2011). Similarly, body condition and reproduction appears stable in the Chukchi Sea population after a period of substantial sea ice decline. The latter may be a result of the high biological productivity of the region and the continued availability of sea ice over shallow, productive, continental shelf waters even during the annual sea ice minimum (Rode and others, 2014). These studies emphasize that geographic variation, ecological conditions, and ecosystem productivity in addition to stressors other than declining sea ice also can be important in affecting polar bear population dynamics.

Although the loss of sea ice habitat can have a direct effect on polar bear persistence, other factors associated with climate change have the potential to adversely affect populations. In most parts of their range, polar bears, with the exception of pregnant denning females, have typically spent most of their annual life cycle on the sea ice. In recent years, polar bears are increasingly spending time onshore where they interact more with humans and infrastructure, including local residents, tourists, and industrial activities. Being onshore increases the potential for lethal outcomes for polar bears. Further, historically, sea ice has acted as a structural barrier to anthropogenic activities in the Arctic Ocean. Continued declines in the extent of summer sea ice and lengthening of the open water season are predicted to result in increased exposure of polar bears to industrial and commercial activities such as the exploration and extraction of oil and gas and trans-Arctic shipping (Gautier and others, 2009; Rogers and others, 2013; Smith and Stephenson, 2013; Stephenson and others, 2013; Miller and Ruiz, 2014). 
Attendant risks of increased anthropogenic activities include exposure to oil spills (Amstrup and others, 2006b), industrial chemicals and effluents (Amstrup and others, 1989; Derocher and Stirling, 1991; Smit and others, 2008), and human-bear conflict. Similarly, extensive sea ice cover may have functioned as a physical barrier to disease agents by limiting contact between polar bears and vectors. Currently, exposure to disease and parasites is believed to not represent a threat to polar bears (Vongraven and others, 2012). Climate change is predicted to alter host-pathogen associations, transmission dynamics, and pathogen resistance (Burek and others, 2008), which is cause for concern given that polar bears have a naïve immune system (Weber and others, 2013) that may make them more vulnerable to emerging infectious agents. The relative effects on population persistence of these stressors and others, such as harvest and availability of terrestrial habitat, are therefore also important to consider.

Assessing diverse stressors affecting population persistence requires the development of a stressor evaluation model that takes as input the magnitudes of the various stressors and produces as output the projected population responses. Importantly for polar bears, such a model needs to be able to incorporate ecological complexity exhibited across the species' range. Probability-based models, in particular Bayesian network (BN) models, have the capacity to integrate environmental, ecological, and anthropogenic processes, along with an explicit representation of uncertainties, into a unified analytical risk-assessment framework (Marcot and others, 2001; Jensen and Nielsen, 2007; Barton and others, 2012). These models also allow for the incorporation of hypothesized relationships where specific data defining relationships between environmental or abiotic stressors are lacking. Uncertainty in relationships can be explicitly incorporated by spreading the resultant probability across positive, negligible, and negative outcomes. Amstrup and others (2008) developed a BN model (hereafter the first generation model), representing the relationships of sea ice habitat and a select group of stressors with polar bear demography, to project the future worldwide status of polar bears. A central conclusion was that aggressively mitigating greenhouse gas (GHG) emissions, along with managing anthropogenic activities, could result in the maintenance of polar bear numbers at reduced but sustainable levels throughout the 21st century (Amstrup and others, 2010). Here, we have adapted this evaluation framework to focus on better understanding the relationships between different stressors with the potential to affect polar bear populations. This framework can be used to identify where focused management may be most beneficial to polar bears by finding the combinations of mitigation for influential stressors that could result in improved population outcomes (Runge and others, 2007).

Our goal was to identify the most influential environmental, ecological, and anthropogenic stressors affecting polar bear population persistence and the degree to which mitigation of those influential stressors could affect their circumpolar persistence. Because quantitative relationships between most stressors and polar bear population dynamics are lacking yet management decisions are needed to promote polar bear conservation, this formalization is an improvement on making decisions where there is not an explicit integration of existing knowledge and hypothesized relationships. This analysis provides a tool that can be used to inform decisions regarding the short- and long-term management of polar bears. Specifically, we (1) updated the structure and content of the first generation BN model using new information available after the model was developed in 2007, (2) identified which stressors have the greatest influence on future population outcomes, and (3) identified the form and management implications of uncertainties in forecasting the response of polar bears to various stressors and their potential mitigations. 


\section{Materials and Methods}

Our study area encompassed the circumpolar range of polar bears, which is comprised of the 19 subpopulations recognized by the Polar Bear Specialists Group of the International Union for the Conservation of Nature (Aars and others, 2006). Because polar bears move between subpopulation boundaries (e.g., Taylor and others, 2001; Amstrup and others, 2004), Amstrup and others (2008) grouped them into four ecoregions based on observed and forecasted future patterns of sea ice dynamics and polar bear life history (fig. 1). Two of the ecoregions - the Polar Basin Convergent Ice (PBCE; three subpopulations) and Archipelago (AE; six subpopulations) ecoregions - have been characterized by persistent multi-year ice that has allowed polar bears to remain on the ice year-round (e.g., Ferguson and others, 2000). The Polar Basin Divergent Ice Ecoregion (PBDE; five subpopulations) historically has been characterized by mixed annual and perennial ice that advects toward the central polar basin (and aggregates in the PBCE) during summer (Durner and others, 2009). For the most part, bears in the PBDE have stayed on the sea ice year-round, although recently, in the southern Beaufort Sea and Chukchi Sea subpopulations, some bears come ashore during summer (Schliebe and others, 2008; Ovsyanikov and Menyushina, 2010). Lastly, the Seasonal Ice Ecoregion (SIE; five subpopulations) is characterized by annual sea ice that melts almost entirely each summer (Derocher and Stirling, 1990). During the functionally ice-free season, which can begin as early as July and continue through October, bears in the SIE come ashore and experience an extended period of food deprivation while waiting for sea ice to reform in the autumn (Stirling and Archibald, 1977).

\section{Revision of the First Generation Model}

We used the first generation model developed by Amstrup and others (2008) as the foundation for the second generation model. The first generation model was used to project the probability of persistence of the circumpolar polar bear population through the 21 st century relative to the influence of climate change, environmental conditions, and anthropogenic stressors. The purpose of the model was associated with a need at the time to inform the ESA listing process by projecting polar bear population outcomes within the foreseeable future using the best available scientific information. Our focus in developing the second generation model was to characterize the potential influence of specific stressors to explore normative (most-expected based on best estimates of likely input values) outcomes under combinations of ecoregions, time periods, and climate change scenarios, and to evaluate potential influences of emissions pathways. The current model incorporates new information since 2007 and restructured the first generation model to reflect current understanding of the dynamics of polar bear population outcomes.

In creating the second generation model, we followed guidelines for developing BN models (Marcot and others, 2006). First, we established a team of subject matter experts (appendix A) to evaluate the first generation influence diagram in light of personal research experience and publications that had become available since the first generation model was constructed. The influence diagram is a graphical model that depicts the causal web of stressors influencing the outcome of interest (Marcot and others, 2006). Following the team's evaluation, we revised the influence diagram accordingly to specify additional stressors and to reflect the current understanding of relationships among stressors that mediate population outcomes. The revised influence diagram reflected both new understanding from recent research and a desire to provide greater detail in the model about specific influences (e.g., various types of potential oil or hydrocarbon spills and pollution associated with energy development activities). 
We updated the sea ice variables based on outputs from current climate models that have been improved since the first generation model was developed. We provide details on the process used to develop and parameterize the model in appendix B.

\section{Model Structure and Parameterization}

The model consisted of input, intermediate, and outcome nodes, with the former two organized into environmental and other stressor submodels (fig. 2). Input nodes are considered "parentless" because their values are not informed by other nodes, and their states are parameterized by unconditional, prior probability values. By contrast, both intermediate and outcome nodes are conditioned on the preceding nodes (or "parent nodes") to which they are linked, which can be both input and other intermediate nodes (Jay and others, 2011). The states of intermediate and outcome nodes are parameterized by conditional probability values. Our input nodes consisted of calculated environmental (e.g., sea ice metrics) and summary anthropogenic (e.g., shipping, hunting, resource extraction) stressors. Ecoregion-specific inputs for parentless sea ice metrics were derived from general circulation models (GCM) as described below in section, "Model Composition," while ecoregionspecific inputs for other parentless nodes were derived through synthesis of available literature and expert knowledge. Intermediate nodes consisted of summaries of stressors, environmental characteristics, and polar bear demographic processes. The outcome node represented the cumulative effect of the input and intermediate nodes, expressed as conditional probabilities of relative influence on polar bear population trend.

The model structure was informed by several important aspects of BN models. First, summary nodes were used to ensure that no more than 3-4 input nodes informed any one intermediate node. Because the combined effects of all inputs at an intermediate node must be estimated, having too many inputs results in large numbers of input combinations which, in turn, makes assigning probabilities very difficult. Secondly, the effect of a stressor is affected by its proximity to the outcome node. Therefore, the model structure had to be designed to ensure that nodes of similar influence were within similar proximity to the outcome node.

Probabilities were assigned at each intermediate and summary node to reflect the range of possible outcomes from each combination of input stressors. Available data from the literature were used to prescribe the likelihood of each outcome. Where data were lacking, expert judgment was used to estimate the range of likely outcomes as well as the degree of certainty. Uncertainty was incorporated by prescribing a more uniform distribution of probabilities across all possible outcomes. Where outcomes had greater certainty as a result of existing data and well-understood relationships, probabilities across outcomes were prescribed more narrowly.

\section{Model Structure for Conducting Scenario Projections}

We conducted separate model runs for combinations of the four ecoregions detailed above, and six time periods, including one historical, one recent, and four future periods extending to the end of the 21st century. A 1985-1995 period represented historical relationships and a 2007-2012 period represented current conditions. Four future periods (2020-2030, 2045-2055, 2070-2080, 2090-2100) represented projected conditions through the end of the century. We evaluated decadal time periods, rather than single years or individual-year time series, to focus on the long-term trends rather than the natural interannual variation in the environmental inputs to the model (Jay and others, 2011). For each of the future time-period model runs, we also evaluated two pathways of GHG forcing (RCP 4.5 and RCP 8.5; see section, "Sea Ice Submodel” below), including two approaches for pooling multi-model 
projections (ensemble means and frequency distributions), and three subsets of GCMs based on published recommendations of the models' ability to simulate observed sea ice conditions. By taking an ecoregion- and time period-specific approach, we were able to represent geographic and temporal variation in stressor effects, GHG emission influences, and uncertainties. A detailed description of model nodes, including definitions of node states and key assumptions, is available in appendix $\mathrm{C}$ and section, "Model Composition." In total, we ran 204 combinations of ecoregion, time period, GHG emission pathway, and GCM subset, on expected (hereafter "normative") conditions (appendix D). Additional "influence runs" were conducted by varying individual input values to determine their specific influence on outcomes; see section, "Sensitivity Analysis and Influence Runs" for details. Conditional probability tables for all intermediate nodes are documented in appendix E.

\section{Model Composition}

The second generation BN model included 10 interlinked submodels (fig. 2). Each submodel is described below and detailed in figure 3.

1. Analysis scenario submodel.-The first submodel pertains to the analysis scenario combinations of ecoregion, time period, GHG emission pathway, and GCM subset. Instead of unduly complicating the model structure by showing explicit linkages from ecoregion, time period, climate change pathway, and GCM set, to every input variable, the linkages were implicit in providing an input "case file" database specifying values of all input variables for each such combination. That is, in the input database, each record was a unique combination of ecoregion, time period, emission pathway, and GCM subset.

2. Sea ice submodel.-Historical and model-projected data were used to parameterize the sea ice input nodes. Historical data consisted of satellite observations of monthly sea ice concentration, obtained from the National Snow and Ice Data Center (NSIDC) archives for 1985-2012 (Cavalieri and others, 1996). These data were distributed in a gridded polar stereographic map projection with 25 $\mathrm{km}$ pixel resolution. For the four future time periods, we used GCM projections of monthly sea ice concentration, obtained from the World Climate Research Programme's Coupled Model Intercomparison Project phase 5 (CMIP5) archive (Taylor and others, 2012) at http://cmippcmdi.llnl.gov/ (accessed May 2013). We acquired sea ice concentration outputs from 13 GCMs (table 1), 2006-2100, that were produced by each of two CMIP5 GHG forcing experiments: Representative Concentration Pathway (RCP) 4.5 and RCP 8.5 (van Vuuren and others, 2011). RCP 8.5 represents a future characterized by an unabated continuation of current rates of increases in anthropogenic components contributing to global warming, and RCP 4.5 reflects a future where anthropogenic contributions stabilize near the year 2040. We also obtained hindcasts of monthly sea ice concentration, 1996-2005, for each of the 13 GCMs from the CMIP5 'historical' forcing experiment. The hindcasts were added to each of the two RCP time series to extend their temporal domain into the latter part of the 20th century. We acquired a single realization (run-1) for each GCM and forcing combination. All GCM outputs were transformed and resampled (nearest neighbor) to a $25-\mathrm{km}$-resolution polar stereographic grid that was congruent to the NSIDC grid of sea ice observations. 
We chose the 13 GCMs (table 1) from among dozens in the CMIP5 archive based on studies by Massonnet and others (2012), Wang and Overland (2013a) and updated in Wang and Overland (2013b). Both studies identified subsets of the CMIP5 models based on their ability to simulate the observed record of sea ice dynamics. Wang and Overland (2013b) found that 12 models simulated means and seasonal cycles in ice extent to within 20 percent of observations, although Massonnet and others (2012) identified six models based also on comparisons with means and seasonal cycles, as well as metrics about ice volume and September trend. Together, the two studies identified 15 unique models, but we excluded 2 lower-resolution models (IPSL-CM5A-LR and MPI-ESM-LR) because their medium-resolution counterparts (IPSL-CM5A-MR and MPI-ESM-MR) were represented. We also excluded five models for analyses in the Archipelago Ecoregion (table 1) because their spatial resolutions did not adequately resolve the region's channels and fjords.

Three quantitative sea ice habitat metrics (i.e., nodes), identical to those used by Amstrup and others (2008), were calculated for each year and ecoregion in both the modeled and observed time series of monthly sea ice concentration maps (appendix C).

- $\quad$ Total ice habitat.-For the two polar basin ecoregions, the PBDE and PBCE, we calculated an annual metric of total ice habitat, depicted by the node "foraging sea ice area," by calculating the 12-month sum of monthly optimal habitat area as defined by Durner and others (2009). Monthly maps of optimal sea ice habitat for the PBDE and PBCE were derived by applying Durner and others (2009) resource selection functions (RSF) to covariates extracted from the respective monthly ice concentration maps. Because the RSF models were not developed for the AE and SIE, we derived an annual metric of total ice habitat for those ecoregions as the annual 12-month sum of monthly sea ice extent, where ice extent was defined as the aerial cover $\left(\mathrm{km}^{2}\right)$ of all pixels with $\geq 50$ percent ice concentration.

- Ice absence.-We calculated the number of reduced-ice months per year over shelf waters from each GCM time series and from observations, and used the node "foraging sea ice $<50$ percent absence" to quantify information about duration of the summer melt period from the preferred continental shelf foraging areas (Durner and others, 2009). A reduced-ice month was defined in a respective ecoregion as a month when $<50$ percent of the area over the continental shelf ( $<300 \mathrm{~m}$ depth) was covered by sea ice of $\geq 50$ percent concentration. Because deep water is uncommon in the AE and SIE, we considered those ecoregions to be entirely comprised of shelf waters.

- $\quad$ Sea ice shelf distance.--Recognizing the potential importance of how far the ice retreats away from the preferred continental shelf foraging areas each year, we calculated a shelf-ice distance metric during the month of minimum (but non-zero) ice extent as the mean distance from every shelf pixel in the respective ecoregion to the nearest pack-ice pixel. The pack ice was defined as the largest contiguous region of ice with $>50$ percent concentration. The shelf-to-ice distance metric, depicted using the node "sea ice shelf distance change," was not calculated for the SIE and AE because we considered all sea ice in those ecoregions to be over shelf waters. 
We used the node "foraging sea ice quality" to express a subjective assessment of the quality of sea ice for foraging by polar bears over time. Recent observations of the changes in sea ice characteristics in several Arctic seas and regions (e.g., southern Beaufort and Chukchi Seas [Mahoney and others, 2012], Hudson Bay [Gagnon and Gough, 2005; Sahanatien and Derocher, 2012]) suggest that changes in sea ice phenology have resulted in thinner ice that more easily deforms and more frequently rafts over itself. In the model, we incorporated the potential for these changes to reduce the quality of sea ice as a foraging substrate in the PBDE and SIE, because extensive ice deformation can limit access to prey (Stirling and others, 2008). Conversely, we incorporated the potential for thinning of thick, multi-year ice in the AE and portions of the PBCE to increase foraging opportunities in the early- and mid-century periods, and reduced foraging opportunities in the late century periods. In both of these cases, due to uncertainty about how sea ice characteristics might affect foraging habitat quality, we allowed for a range of negative, negligible, and positive impacts that varied with sea ice conditions and ecoregion. We used the intermediate node "foraging sea ice distribution" to express how the spatiotemporal retreat of sea ice may affect availability of continental shelf habitats. Similarly, we used the intermediate node "overall sea ice conditions" to characterize the combination of the quantitative and qualitative ways the retreat of sea ice may affect use of continental shelf habitats by polar bears.

As noted above, we focused our GCM analyses on four future decadal periods and our observationbased analyses on two contemporary periods. Observation-based analyses incorporated all available data on known relationships and effects, and also used expert knowledge where data were not available. Ice metrics from observations and the individual GCMs were respectively averaged within each decadal period to smooth the Arctic's intrinsic interannual sea ice variability, and improve detection of the GHG forced trend. Next, the decadal metrics were expressed in units of change from a baseline decade (1996-2006) to lessen the influence of inherent biases among individual models (Knutti, 2008). With respect to the baseline decade, total ice habitat was expressed as a percent change, ice absence as a change in months, and shelf-ice distance as a change in kilometers. In preparation for entry into the model, these continuous variables describing change were assigned to categories (bins) defined by the structure of the respective input node. Our input nodes for all three metrics of sea ice change were structured similar to those of Amstrup and others (2008), with a comparable range of values but partitioned into slightly more bins. One exception, however, was that we scaled the bins in the "foraging sea ice $<50$ percent absence" node (change in the number of ice-free months) over a broader range of months to accommodate the RCP 8.5 GHG forcing that projects a warmer world with longer ice-free summers compared to the Special Report on Emissions Scenarios (SRES) A1B forcing scenario evaluated by Amstrup and others (2008).

As described above, we prepared six different variants of the sea ice metrics to determine whether different GCM ensembles and data summaries qualitatively affected the final BN outcomes. We considered each of three different GCM ensembles: (1) the 5 models selected by Massonnet and others (2012); (2) the 11 models selected by Wang and Overland (2013b); and (3) the 13-model union of the aforementioned (hereafter called GCM-05, GCM-11, and GCM-13). Second, for each ensemble, we considered two methods of treating a metric's multi-model variance: (1) pool the variance into a multi-model average; and (2) represent the multi-model variance as a frequency distribution across all bins of the respective input node. In total, our analytical framework described above evaluated the 204 unique BN runs as defined by the combinations of five factors: four ecoregions (PBDE, PBCE, SIE, and AE); two GCM forcing pathways (RCP4.5 and RCP8.5); four future decades (historical, early century, mid-century, late century, and end century); three GCM ensembles (GCM05, GCM11, and GCM13); and two treatments of multi-model variance (average 
and frequency distribution); plus 12 observation-based BN runs that combined three contemporary decades across four ecoregions. We hereafter refer to these combinations of factors and their respective BN runs as the 'normative scenarios' (appendix D).

3. Marine prey and conditions submodel. - We used the "secondary and new prey abundance" node to express changes in the abundance of alternative marine mammal prey, and to allow range expansion into Arctic waters by novel prey species, as sea ice extent declines and ice phenology and characteristics change over time. Changing sea ice conditions may adversely affect the abundance of primary prey thus making secondary prey more important. For example, spotted (Phoca largha) and ribbon seals (Histriophoca fasciata) are mostly distributed in the sub-Arctic waters of the Bering Sea, although part of their range extends into the Chukchi Sea. As pack ice becomes less available in the Bering Sea, ribbon seal range will likely expand northward to maintain access to pack ice during the birthing period (Lowry and Boveng, 2009). Spotted seals regularly haul out on shore and are less reliant on sea ice. As a result, the range of spotted seals may expand northward as summer ice cover declines (Kovacs and others, 2012). Last, ribbon, harp (Pagophilus groenlandicus), and hooded seals (Cystophora cristata) can spend long periods pelagically in areas without ice (Kovacs and others, 2012), likely making them somewhat resilient to loss of sea ice habitat. The prey abundance input nodes do not consider availability because availability to prey was accounted for under nodes related to sea ice conditions. We acknowledge that seals may occupy areas that make them less available to polar bears even if seals are still relatively abundant.

We used three input nodes to characterize the abundance of primary and secondary prey. The "ringed seal abundance" and "bearded seal abundance" nodes were used to express the probability that changes in abundance of primary prey are likely to occur as sea ice cover declines and its character changes. For example, we incorporated evidence that earlier spring break-up of sea ice in western Hudson Bay is related to declining pup survival (Ferguson and others, 2005). Declining sea ice may reduce the availability of birthing and haul-out habitat for seals, and earlier break-up may also adversely impact pup survival by interrupting the lactation period (Kelly and others, 2010). Ringed seals have the longest lactation period of the Phocidae and need stable ice as well as sufficient snow for lairs until neonates are weaned (Lydersen and Kovacs, 1999). We incorporated the potential that in some areas, declines in sea ice may improve biological productivity of the ocean, which may benefit seals in the near-term. However, we also considered evidence that increased primary productivity will be greatest during summer (after break-up) and benefits may be mitigated by reduced biomass in coastal/shelf areas due to increased river run-off and associated changes in turbidity and salinity (e.g., Bluhm and Gradinger, 2008). In the model, we assumed that only in the northern part of the ice convergent zone of the Polar Basin and in portions of the Archipelago are conditions likely to improve for ringed seal availability_particularly if biomass is reduced in coastal/shelf waters but increases elsewhere. However, such improvements are likely to be transient perhaps through mid-century.

Ringed and bearded seal abundance nodes were linked to the "marine prey base quality" intermediate node to express cumulative primary and secondary prey abundance. As with the ringed seal and bearded seal abundance nodes, the conditional probability table (CPT) for "marine prey base quality" was based on expert judgment because little information was available to suggest how the prey base quality is likely to change in the future. In developing the conditional probabilities for this node, we gave primary prey slightly greater weight than secondary prey. We did this because the importance of primary prey has been established in the literature, while there is relatively little information available on the likelihood/importance of prey switching. However, we did recognize 
evidence (e.g., Peacock and others, 2013) that increased abundance of alternate prey in some areas could compensate for losses of ringed or bearded seals and may even result in transient improvements of polar bear survival.

4. Terrestrial food/prey and conditions submodel.-Use of terrestrial habitat is a significant aspect of the life-history of polar bears residing in the SIE and parts of the PBDE (e.g., Schliebe and others, 2008). We expected that use of terrestrial habitat would increase over time. Accordingly, we created three input nodes to describe the use of terrestrial refugia habitat and food resources. "Humanprovisioned food abundance" was used to express the availability of human-harvested marine mammals and other prey to polar bears in terrestrial habitats. The availability of human-provisioned food is most pertinent during the late summer and early autumn when sea ice reaches its minimum extent. This node is mostly relevant to a part of the PBDE where bears come ashore during the late summer to exploit bowhead whale (Balaena mysticetus) carcass sites (Herreman and Peacock, 2013). The "terrestrial and marine prey access" node expressed the availability of terrestrial prey and other terrestrial food resources (e.g., Derocher and others, 1993; Smith and others, 2010). We used the intermediate node "overall terrestrial prey/food" to characterize the availability of food resources relative to requirements of bears during their stay on shore, while noting that the availability of human-provisioned food is mostly relevant to portions of the PBDE and SIE. We used the node "bears on shore" to express the length of time each year that bears may spend on shore exploiting terrestrial habitat as influenced by changes in overall sea ice conditions, terrestrial prey, and ecoregion. "Terrestrial habitat quality" was used to characterize stability in habitat structure and extent of human and natural disturbance over time. The node "overall terrestrial conditions" was used to depict changes in onshore habitat suitability as a function of habitat quality and the length of time bears spend on shore. Last, the nodes representing overall marine and terrestrial conditions were used to inform "overall habitat suitability," where greater importance was attributed to "overall marine conditions" because polar bears spend the majority of the year on sea ice foraging on marine mammals.

5. Overall habitat suitability submodel.-This single-node submodel combines overall marine conditions with overall terrestrial conditions into a summary of overall habitat suitability which, in turn, directly affects polar bear demographic conditions.

6. Event-driven mortality submodel.-We depicted mortality as a function of specific known and hypothesized lethal stressors including harvest and take resulting from human-bear conflict (i.e., defense of life and property; DLP). Polar bears are legally harvested in the U.S., Canada, and Greenland; harvest is illegal in Russia and Norway. Historical harvest levels were well-documented (e.g., Obbard and others, 2010), but future levels are entirely speculative. In parameterizing the harvest node, we assumed that future harvest would scale to habitat carrying capacity in an attempt to maintain sustainability. The harvest input node has three states and we considered "same as recent" and "reduced" to represent harvest at or below sustainable levels; "increased" represented harvest above a level considered sustainable. In parameterizing the input node representing DLP take resulting from human-bear conflict, historical patterns also were well-documented (e.g., U.S. Fish and Wildlife Service, unpub. data; Towns and others, 2009). We assumed that future levels of DLP take would increase as sea ice extent declines and forces bears to come ashore in greater numbers for increasing lengths of time. Harvest and DLP input nodes were summarized by an intermediate node, "event-driven mortality." 
Additional input nodes used to depict mortality risks included oil spills due to small and large exploration and extraction operations, and a catch-all node encompassing multiple risks such as those resulting from management and research activities and catastrophic storm events. These nodes had three states (increased, baseline, and reduced). Historical conditions were documented to the extent possible, and we assumed future conditions might be related to sea ice extent and duration of the ice-reduced period. For example, we incorporated within the outcome probabilities a possibility that declines in sea ice extent and a longer open-water season would facilitate increased oil extraction activity and elevate the risk of accidental oil spills (Amstrup and others, 2006a). We also considered the potential for these stressors to have no effect on future conditions. These additional mortality risk input nodes were summarized by an intermediate node termed "other mortality or removal events," and linked to the "event-driven mortality" node. Event-driven mortality was then used to inform adult and subadult survival nodes.

7. Anthropogenic stressors submodel. - We included several input nodes that allowed for potential effects of sub-lethal stressors and pollutants associated with different forms of anthropogenic activities. Sub-lethal stressors, such as "human-bear sub-lethal interactions," "oil, gas, and mining activity," "shipping," and "tourism" might cause bears to be displaced from foraging and refugia habitat. Historically, offshore resource extraction, commercial shipping, and recreational activities have been limited by sea-ice extent, but will likely increase as sea ice extent declines (Ebinger and Zambetakis, 2009; Peters and others, 2011; Smith and Stephenson, 2013). Likewise, increased levels of anthropogenic activity might result in increased human-bear interactions. The effect of these stressors was summarized using the "sub-lethal human disturbance" intermediate node.

We used two nodes, "hydrocarbon/oil spill" and "contaminants," to characterize potential patterns of exposure to specific point-source (e.g., associated with drilling operations and shipping) and transported (e.g., organic compounds) pollutants. For the latter, a large body of literature details historical patterns of polar bear exposure to persistent organic pollutants (POP; e.g., Sonne and others, 2012). For some populations, the concentrations of contaminants in polar bear adipose tissue have declined in recent years (e.g., McKinney and others, 2010). However, there are many populations for which no information is available and documented population-level effects of contaminants are limited. There is concern that extensive melting of multi-year sea ice will release sequestered POPs (Ma and others, 2011) that will then increase risk of exposure to bears and other marine mammals. We used the "pollution (sub-lethal)" intermediate node to summarize the effects of exposure to hydrocarbons and contaminants. Probabilities of outcomes were distributed broadly to reflect uncertainty in the potential effects of changes in these stressors over time. We used the "anthropogenic stressors" node to summarize the potential cumulative effects of sub-lethal human disturbance and pollution, and then linked it to "adult female body condition" given the potential for cumulative stress effects to adversely affect fitness (Love and others, 2013; Sheriff and Love, 2013).

8. Other biotic stressors submodel.-Historically, exposure to disease and parasites has not represented a threat to the persistence of polar bears. However, climate change may alter hostpathogen associations, transmission dynamics, and host and pathogen resistance (Burek and others, 2008), which might make polar bears increasingly vulnerable to new pathogens over time. Similarly, intraspecific predation is believed to be rare (Lunn and Stenhouse, 1985; Derocher and Wiig, 1999; Amstrup and others, 2006b), but may increase as bears spend more time on shore and competition for food resources intensifies. We summarized the probabilities of potential effects of disease and parasites and intraspecific predation with an intermediate node ("other biotic stressors"), which was linked to subadult survival. We also linked parasites and disease to an intermediate node 
characterizing adult female body condition, based on the documented relationship between the two for other species (e.g., Møller and others, 2003; Irvine and others, 2006). Because of a lack of documented population-level effects of disease and predation, we incorporated substantial uncertainty when defining probabilities of outcomes associated with these nodes.

9. Demographic submodel.-The demographic submodel was used to represent the cumulative influence of stressors on polar bear vital rates and, ultimately, the relative influence on population trend. The "adult survival" node represented the sum of effects on survival as influenced by "overall habitat suitability," "disease and parasites," and "event-driven mortality." Based on the link between sea ice habitat, body condition, and survival (Regehr and others, 2007, 2010; Rode and others, 2010), we assumed that declines in habitat suitability would adversely affect condition and survival. Likewise, we acknowledged the supposition that sublethal stressors (e.g., disease and parasites, pollution, human disturbance) are likely to increase as the Arctic continues to warm (Moore and Huntington, 2008), and adversely affect female body condition. Because there is no information to establish a direct relationship between sublethal effects and disease to polar bear body condition, we relied on literature from other species (e.g., Pioz and others, 2008; Sheriff and others, 2009) to inform the influence of these effects in the conditional probability table for "adult female body condition."

We used the "recruitment" node to reflect the effect of stressors on the ability of females to reach traditional denning areas and on numbers of cubs produced. There is a well-documented link between adult female body condition and recruitment for polar bears (e.g., Derocher and Stirling, 1995; Rode and others, 2010) and other ursids (Robbins and others, 2012), as well as information reflecting the importance of terrestrial denning habitat for polar bears in multiple ecoregions (Richardson and others, 2005; Fischbach and others, 2007; Andersen and others, 2012). In some areas, reduced sea ice conditions have led to a reduction in access to and use of traditional denning areas (Derocher and others, 2011). In developing the probability table for this node, we considered that lengthening of the ice-minimum season could have adverse effects on adult female body condition and access to terrestrial denning habitat. However, probabilities were spread to also allow for a lack of effect of declining sea ice on female body condition as has been reported from some studies (Rode and others, 2014).

10. Polar bear persistence submodel.-The outcome node "relative influence on population trend" represented the hypothesized potential for population viability given the strength of individual and cumulative threats deemed likely to affect polar bears. The node was informed by adult survival, subadult survival, and recruitment, and in creating the conditional probability table, we attributed the greatest weight to adult survival because it is the most important factor affecting population trend and also the least sensitive to change (Wielgus and others, 2008). This node has four response states, which we defined as follows:

- increased: polar bears occur in numbers that are increased compared to the recent period and distribution is at least the same, although stressors may cause local variation in abundance and distribution;

- same as recent: polar bears occur in numbers and have a distribution that is similar to the recent period. Although stressors may cause local variation in abundance and distribution, they are not expected to induce an increasing or decreasing trend.

- decreased: polar bears occur in numbers and have a distribution that is decreased compared to the recent period, and the reduced numbers and distribution are likely to make the population susceptible to stressors that may cause further declines in abundance and/or occupancy; and 
- greatly decreased: polar bears occur in numbers and have a distribution that makes them difficult to detect, and the reduced numbers make the population vulnerable to stressors that may lead to further declines in abundance and polar bears being restricted to a fraction of their historical range.

We chose to simplify the model outcome node by not including a state "greatly increased". Based on prior modeling and much if not all of the polar bear literature on global and ecoregional conditions and trends, and on the future climate-change and stressor conditions specified in the modeled scenarios, we would never expect future conditions to provide for a "greatly increased" relative influence on population trend at the ecoregional scale. Accordingly, a "greatly increased" state would remain at zero probability under all projected scenarios, thus adding no information to the model outcomes.

We compared the probabilities of the response states among each analysis scenario to identify potential differences in the cumulative effect of stressors on population trend. Similar to Jay and others (2011), we considered these results to be normative outcomes based on modeled best estimates of the response of polar bears to stressor combinations. That is, normative outcomes are expected results given our current understanding of the effects of managed and unmanaged stressors on polar bear populations.

\section{Sensitivity Analysis and Influence Runs}

We conducted sensitivity analysis and influence runs with the modeling shell Netica ${ }^{\circledR}$ using methods and interpretations described in Marcot (2006; 2012) and Jay and others (2011). Sensitivity analyses were used to determine which model nodes were key drivers of outcomes, and to provide information on the inherent underlying conditional probability structure of the model (Morgan and Henrion, 1990; Darwiche, 2009).We used influence runs (for both RCP 4.5 and 8.5)-also termed joint parametric analysis by Morgan and Henrion (1990) - to examine the effect that mitigation of select stressors may have on relative population trend, and to rank stressors in order of their importance. Influence runs entail setting specified input variables to their extreme states while holding other inputs to their normative scenario values. This helps determine best- and worst-case outcomes, and in particular is useful for ascertaining the potential benefits (or detriments) of mitigation of those inputs that are potentially controllable by management, including much of event-driven mortality and anthropogenic stressors. For individual anthropogenic and biotic stressors, such as trans-Arctic shipping, tourism, resource extraction activities, and parasites and disease, we assigned select input nodes best- and worst-case scenarios (e.g., reduced activity versus increased activity) and compared outcomes between the two cases. We took a similar approach for evaluating the influence of stressors comprising the event-driven mortality submodel. Additionally, we conducted group-based influence runs on the disparate stressors that comprised the event-driven mortality submodel. This allowed us to compare the potential influence of reduction in intentional take (through legal harvest and DLP killing) versus a reduction in other lethal stressors (e.g., oiling events, catastrophic weather, illegal killing). We then qualitatively compared the outcomes of influence runs to the normative model outcomes to determine the relative influence that managing the strength of select stressors may have on model outcomes. 


\section{Comparison of Polar Bear Ecoregion Outcomes under Stabilized and Unabated GHG Emissions Pathways}

To examine the effect of GHG emission levels on potential population trend, we compared outcomes between RCP 4.5 and RCP 8.5, while holding all other input nodes to their original values for future periods. RCP 4.5 and 8.5 represent two possible future GHG emission pathways. RCP 4.5 corresponds to a stable end-of-century net radiative forcing of $+4.5 \mathrm{~W} / \mathrm{m}^{-2}$ above preindustrial levels, while RCP 8.5 corresponds to an increasing (unstabilized) net forcing of $+8.5 \mathrm{~W} / \mathrm{m}^{-2}$ at the end of the century. For RCP 4.5, $\mathrm{CO}_{2}$ emissions slowly increase until mid-century and then decrease to the last quarter of the century where they stabilize at approximately 50 percent of 2000 levels; atmospheric $\mathrm{CO}_{2}$ concentration stabilizes at slightly more than $500 \mathrm{ppm}$. For RCP 8.5, $\mathrm{CO}_{2}$ emissions quickly rise through mid-century and continue to rise through the end of the century; atmospheric $\mathrm{CO}_{2}$ concentration also increases through the century reaching well over three times the current level (Meinshausen and others, 2011; van Vuuren and others, 2011). Projected northern hemisphere September sea ice extent for both RCPs is similar during the early part of this century, but significantly diverges by mid-century and beyond (fig. 4).

\section{Results}

\section{Sensitivity Analysis}

The final outcome node (i.e., "relative influence on population trend") was most sensitive to nodes pertaining directly to sea ice, marine prey (ringed seal abundance), and differences among ecoregions (fig. 5). The availability and distribution of sea ice is directly influenced by climate change, while the link between marine prey conditions and climate may be direct or indirect, depending on the species. The AE and SIE are considered to be entirely comprised of shelf waters and foraging sea ice area and change is more gradual than in the PBDE and PBCE, where there is a sharply defined shelfbreak.

\section{Basis for the Normative Model Results}

Outcome probabilities among the four final outcome node states (increased, same, decreased, and greatly decreased) were qualitatively similar regardless if sea ice input metrics were derived from the 5-model ensemble identified by Massonnet and others (2012), or the 11-model ensemble identified by Wang and Overland (2013b). When the multimodel variance for each sea ice metric was represented as a frequency distribution, the average absolute difference across all outcome states between the 5model and 11-model ensembles (for all but the AE) was less than 1 percent (mean difference $=1.05$ percent $\pm 1.69 \mathrm{sd}, \max =9.94$ percent, 95 th percentile $=3.78$ percent, $\mathrm{n}=96)$. The sample size $(96)$ equates to the product of 4 outcome states, 4 decades, 2 forcing pathways, and 3 ecoregions. The AE was excluded because only two of the five models identified by Massonnet and others (2012) had adequate spatial resolution within the Archipelago (table 1). Similarly, when the ice metrics were input as ensemble means, the average absolute difference among all outcome probabilities between the 5model and 11-model ensembles also was small (mean difference $=1.05$ percent $\pm 1.92 \mathrm{sd}, \max =9.40$ percent, 95 th percentile $=5.61$ percent, $\mathrm{n}=96$ ). Given the similarity between the outcome probabilities 
by the 5-model and 11-model ensembles, we henceforth present results derived exclusively with ice metrics from the 13-model union of the two ensembles (i.e., all models in table 1). We opted to use the larger union of models afforded by the two subsets to broaden the representation of climate model constructs in our analysis (Knutti and others, 2010).

Regardless of whether the sea ice variance among the 13 models was represented as a frequency distribution or as an ensemble average, we again found little qualitative absolute difference between the resulting outcome probabilities (mean difference $=1.06$ percent $\pm 1.27 \mathrm{sd}$, $\max =6.83$ percent, 95 th percentile $=3.53$ percent, $\mathrm{n}=128$ ). Consequently, we chose to report results based solely on the 13 model ensemble in which the multimodel variance for each ice metric was represented as a frequency distribution of prior probabilities. We refer to the Bayesian model runs that used these sea ice metrics as 'normative runs,' applied once using ice inputs from each of the two GHG forcing pathways: RCP 4.5 and RCP 8.5.

\section{Normative Model Results}

For the normative model runs, polar bear outcomes from the historical (1985-1995) and recent observation periods (2007-2012) were similar for the AE, SIE, and PBCE, with each of the three ecoregions having dominant probabilities of either "increased" or "same as recent" (fig. 6). In contrast, the PBDE transitioned from a dominant outcome of "increased" during the historical period (1985-1995) to "greatly decreased" during the recent (2007-2012) time period. There was considerable uncertainty in the PBDE outcome for the recent time period, with probabilities closely distributed among "same as recent," "decreased," and "greatly decreased." For future outcomes, the other ecoregions reached dominant probabilities of "decreased" and "greatly decreased" at different time periods (fig. 6). The PBDE maintained a dominant probability of "greatly decreased" in all future time periods under both RCP 4.5 and 8.5. The PBCE transitioned to dominant probabilities of "decreased" in the early century (2020-2030) and to "greatly decreased" at mid-century (2045-2055) under both RCPs. Similarly, the SIE shifted to a dominant probability of "decreased" in the early century and to "greatly decreased" at mid-century under both RCPs. The AE reached a dominant probability of "decreased" by the late century (2070-2080) under RCP 4.5 and remained in that state through the end of the century (2090-2100). Under RCP 8.5, the AE reached a dominant probability of "decreased" by the mid-century time period, and "greatly decreased" by the end of the century.

Uncertainty among normative outcome states decreased monotonically over time, as evidenced by the decreasing spread of probabilities among the outcome states (fig. 6). In general, probabilities of "increased" and "same as recent" states declined, while probabilities of "decreased" and "greatly decreased" states rose. As a result, uncertainty among future model outcomes was mostly distributed across those latter two states, with the exception of the AE where uncertainty also was distributed among "same as recent." Overall, uncertainty in polar bear outcomes was greatest for the AE, and least for the PBDE.

\section{Influence Runs}

"Overall sea ice conditions" and "marine prey base" consistently had the greatest influence on polar bear ecoregion outcomes, followed by "event-driven mortality," "hunting," and "defense of life and property (DLP; lethal)" (appendix F). Other potential stressors, such as "pollution," "shipping," "tourism," and "oil and gas extraction activities" had minimal influence on polar bear outcomes given the far greater influence from sea ice and marine prey conditions. Below we examine the specifics by ecoregion. 
PBDE.-For the PBDE, maximizing (individually) the stressors "overall sea ice conditions" or "marine prey base" (by setting states to minimal values) caused "probabilities of decreased or greatly decreased" to rise by 5-11 percent for "overall sea ice conditions" and by 3-8 percent for "marine prey base" through the end of the century compared to the normative value. By contrast, minimizing those stressors (by setting the states to maximal values) lowered the projected "probabilities of decreased or greatly decreased" by about 57 percent (for "overall sea ice conditions") or about 15 percent (for "marine prey base") through the end of the century. Minimizing those stressors had a more pronounced effect on the "probability of greatly decreased," which lowered the projected probabilities of "greatly decreased" by 40-75 percent ("overall sea ice conditions") and 10-20 percent ("marine prey base") (fig. 7a-d). The lowest levels of "harvest" or "DLP" caused "probabilities of decreased or greatly decreased" to decline by 1-3 percent through the end of the century. Setting the "harvest" state to the maximal value resulted in an increase of "probabilities of decreased or greatly decreased" of 2-5 percent. Setting the "DLP" state to the maximal value had a negligible effect on outcomes.

We also considered cumulative stressor effects by assessing the influence on outcomes of bestand worst-case scenarios for "event driven mortality" and "anthropogenic stressors" nodes. For the former, which summarizes the combined influence of "harvest," "DLP," and "other mortality or removal events" (which includes potential mortality from oil spills), setting the node state to the bestcase scenario (minimal value) lowered "probabilities of decreased or greatly decreased" by 2-6 percent through the end of the century. By comparison, the best-case scenario for "anthropogenic stressors" lowered probabilities of decreased or greatly decreased" by $<3$ percent through the end of the century. The worst-case scenarios for "event-driven mortality" and "anthropogenic stressors" raised "probabilities of decreased or greatly decreased" by 5 and 1 percent, respectively, through the end of the century. Last, we conducted a "maximum management" influence run by simultaneously minimizing all manageable (i.e., shipping, tourism, oil and gas extraction, human-polar bear interactions [sub-lethal], exposure to pollutants, and event-driven mortality) stressors on population outcomes, which lowered probabilities of "decreased or greatly decreased" by about 5 percent.

PBCE.-For the PBCE, "overall sea ice conditions" was the most influential stressor followed closely by "marine prey base" for all time periods. As with the PBDE, "event-driven mortality," "hunting," and "DLP" exerted some influence on polar bear outcomes. The "pollution," "shipping," "tourism," and "oil and gas extraction activities" nodes had a negligible influence on outcomes. Maximizing "overall sea ice conditions" and "marine prey base" caused "probabilities of decreased or greatly decreased" to increase by 7-35 percent through the end of the century. Minimizing "overall sea ice conditions" lowered "probabilities of decreased or greatly decreased" by about 32-56 percent. Similarly, minimizing "marine prey base" lowered "probabilities of decreased or greatly decreased" by about 13 percent. Alternatively, maximizing "overall sea ice conditions" caused "probabilities of decreased or greatly decreased" to rise by 6-35 percent. Minimizing "overall sea ice conditions" and "marine prey base" lowered the projected "probability of greatly decreased" by 20-40 percent (fig. 8a-d).

Minimizing "harvest" caused "probabilities of decreased or greatly decreased" to decrease by 2-5 percent through the end of the century, while maximizing "harvest" resulted in an increase of "probabilities of decreased or greatly decreased" of 2-8 percent. Setting the "DLP" state to maximal and minimal values had a negligible effect on "probabilities of decreased or greatly decreased." Minimizing the level of "event-driven mortality" lowered "probabilities of decreased or greatly decreased" by about 3-5 percent, while maximizing the level increased "probabilities of decreased or 
greatly decreased" by 3-9 percent. By contrast, minimizing or maximizing the level of "anthropogenic stressors" had little influence (i.e., < 1 percent) on lowering or increasing "probabilities of decreased or greatly decreased". The combined worst-case scenarios for "event-driven mortality" and "anthropogenic stressors" raised the projected "probabilities of decreased or greatly decreased" by 4-10 percent. The "best management practices" influence run lowered "probabilities of decreased or greatly decreased" by 5 percent.

SIE.-For the SIE, "overall sea ice conditions" was the most influential stressor followed closely by "marine prey base" for all time periods. As with the PBDE and PBCE, "event-driven mortality," "hunting," and "DLP" exerted some influence on polar bear outcomes, while "pollution," "shipping," "tourism," and "oil and gas extraction activities" nodes had little influence. Maximizing "overall sea ice conditions" and "marine prey base" caused "probabilities of decreased or greatly decreased" to increase by 8-23 percent through the end of the century. Minimizing "overall sea ice conditions" lowered "probabilities of decreased or greatly decreased" by about 32-56 percent, while minimizing "marine prey base" lowered "probabilities of decreased or greatly decreased" by about 13 percent. Maximizing "overall sea ice conditions" caused "probabilities of decreased or greatly decreased" to rise by 6-35 percent, and minimizing "overall sea ice conditions" and "marine prey base" lowered the projected "probability of greatly decreased" by 5-17 percent (fig. 9a-d).

Minimizing "harvest" caused "probabilities of decreased or greatly decreased" to decrease by 2-5 percent, while maximizing "harvest" resulted in an increase of "probabilities of decreased or greatly decreased" of 2-8 percent. Maximal and minimal values of DLP had a negligible effect on "probabilities of decreased or greatly decreased." Minimizing the level of "event-driven mortality" lowered "probabilities of decreased or greatly decreased" by about 3-5 percent, while maximizing the level increased "probabilities of decreased or greatly decreased" by 3-9 percent. Changing the level of "anthropogenic stressors" had little influence (i.e., $<1$ percent) on lowering or increasing "probabilities of decreased or greatly decreased". The combined worst-case scenarios for "event-driven mortality" and "anthropogenic stressors" raised the projected "probabilities of decreased or greatly decreased" by about 1 percent. The "best management practices" influence run lowered "probabilities of decreased or greatly decreased" by 5 percent.

AE.-For the AE, "overall sea ice conditions" and "marine prey base" were the most influential stressors, followed by "event-driven mortality," "hunting," and "DLP." Other evaluated stressors had minimal influence on polar bear outcomes. Minimizing "overall sea ice conditions" lowered "probabilities of decreased or greatly decreased" by 17-30 percent through the end of the century, while maximizing the value of that node increased "probabilities of decreased or greatly decreased" by 30-51 percent (fig. 10a-b). Minimizing "marine prey base" lowered "probabilities of decreased or greatly decreased" by about 18 percent, while maximizing the value caused "probabilities of decreased or greatly decreased" to increase by 17-32 percent. Minimizing "overall sea ice conditions" and "marine prey base" lowered the projected "probabilities of greatly decreased" by 20-40 percent and 5-17 percent, respectively (fig. 10a-d). The relative influence of "harvest" and "DLP" was similar to other ecoregions. Minimizing the level of "harvest" lowered "probabilities of decreased or greatly decreased" by 3-5 percent, while maximizing the level of "harvest" increased "probabilities of decreased or greatly decreased" by 5-7 percent. Minimizing the level of "DLP" lowered "probabilities of decreased or greatly decreased" by 1-2 percent, while maximizing the level of "harvest" resulted in an increase by a similar amount. 
Minimizing the level of "event driven mortality" lowered "probabilities of decreased or greatly decreased" for the AE by about 6 percent, while maximizing the level increased "probabilities of decreased or greatly decreased" by 8-11 percent. Minimizing or maximizing the level of "anthropogenic stressors" had little influence (i.e., $<1$ percent) on lowering or increasing "probabilities of decreased or greatly decreased." The combined worst-case scenarios for "event-driven mortality" and "anthropogenic stressors" raised "probabilities of decreased or greatly decreased" by 10-12 percent, while combined best-case scenarios lowered "probabilities of decreased" or greatly decreased" by 6-9 percent. Implementing "best management practices" lowered "probabilities of decreased or greatly decreased" by about 7 percent.

\section{Discussion}

We created a second generation model to identify which stressors were likely to have the greatest influence on polar bear persistence in four ecoregions, and to characterize the implications of uncertainties in the future strength of stressors relative to those outcomes. We found that polar bear ecoregion outcomes were likely to worsen over time through the end of the century, and be accompanied by decreased uncertainty among the "increased" and "same as recent" states. Management interventions to mitigate stressors had the greatest positive impact on population outcomes when made in the early and mid-century periods; the potential benefits of such interventions declined over time. However, it is important to consider model projections within the context of uncertainties we attempted to characterize. Uncertainty in our outcomes can arise from a limited understanding of the ecological and physical system, how we represent that system in the model, and uncertainty in predictions of abundance and distribution (Amstrup and others, 2008).

Our model comprised elements representing climate-mediated sea ice dynamics, suites of biotic and abiotic stressors, and key polar bear population vital rates. The complexity of the system required us to incorporate a wide breadth of information regarding the response of polar bears to environmental change, including empirical data, model-projected data, and expert judgment, which is a key advantage of using a BN approach (Marcot and others, 2006; Marcot, 2007; Pollino and others, 2007). Because we were able to leverage the architecture of the first generation BN model (by using that model as a starting point in developing the second generation model), our current effort represented a further verification, and in some cases refinement, of our understanding of the polar bear's ecosystem and how to structure it in a model framework.

We also, to the extent practicable, represented uncertainty in the estimation of probabilities associated with model nodes. For example, we used GCM outputs, which generally have wide margins of uncertainty (Murphy and others, 2004), to prescribe sea ice metrics. To represent the spread of uncertainty that accompanies those metrics, we used three different GCM ensembles (GCM05 based on models selected by Massonnet and others [2012]; GCM11 based on models selected by Wang and Overland [2013b]; and the 13-model union of GCM05 and GCM11), and portrayed variance as both a multi-model average and a frequency distribution (e.g., Jay and others, 2011). We reflected uncertainty (including potential for interactions between stressors) in other model nodes by spreading probabilities among outcome states more uniformly in the input and conditional probability tables. The spread of probabilities in non-sea ice nodes, which was based on expert judgment and derived iteratively through a repeated group consultation process, conveys important information about our current and future understanding of the strength of stressors we evaluated. Our modeling did not explicitly consider threshold or "tipping point" effects of rapid reductions in polar bear population trend outcome given progressively incremental increases in the various stressors (see Drake and Griffen, 2010, and 
Guntenspergen, 2014, for examples in other ecosystems and theoretical discussions). Although such potential threshold effects on polar bears have been postulated by others (Derocher and others, 2013; Dai and others, 2012; but see Amstrup and others, 2010), we chose not to explicitly include those speculative effects because (1) we lack empirical data or understanding of how such effects would be structured (and thus parameterized) and (2) the purpose of our modeling was to provide a description of the potential for multiple stressors to affect polar bear populations rather than to determine potential thresholds or tipping points in stressor effects.

\section{Normative Model Runs}

Polar bear populations in each ecoregion evidenced a progressively greater probability of a declining trend through future time periods. These results are qualitatively similar to the findings of Amstrup and others (2008), despite fairly significant differences in key aspects of the modeling approach. First, the second generation model was developed primarily to assess the relative influence of stressors on population outcomes, while the first generation model was developed to project future population numerical and distribution responses. Thus for the second generation model, we incorporated a broader complement of known and putative stressors of polar bear populations, some of which are well documented while others are not. As a result, we introduced greater uncertainty into the second generation model, so the outcomes should be viewed as hypotheses about how future stressor conditions may influence ecoregion outcomes. Other key differences between the two efforts include the use of GCM ensembles from the CMIP5 archive (Taylor and others, 2012), as opposed to CMIP3 (Meehl and others, 2007) used for the first generation model, a larger pool of experts with more diverse experience and knowledge, and different outcome states.

Based on normative model runs, polar bear population status in the PBDE, PBCE, and SIE were most likely to experience worsening outcomes through the end of the century. Future outcomes were most dire for the PBDE, which transitioned to a dominant probability of "greatly decreased" in the early century (2020-2030), regardless of the RCP used. By contrast, the PBCE transitioned to dominant probabilities of "greatly decreased" by mid-century (2045-2055) regardless of RCP, while the SIE reached a dominant probability of "greatly decreased" by early century for RCP 8.5 and by mid-century for RCP 4.5 Ecoregion outcomes were highly sensitive to sea ice metrics, most notably "foraging sea ice area," which expressed the proportional change in area of foraging sea ice habitat (as determined in Durner and others, 2009) over time (appendix C). The Arctic-wide sea ice melt season (i.e., period between the onset of sea ice melting in summer and freeze-up in autumn) has increased at a rate of about 5 days per decade since 1979 (Stroeve and others, 2014). The lengthening melt season has been driven primarily by later autumn freeze-up dates in the southern Beaufort, Chukchi, Kara, and Laptev Seas (Perovich and others, 2011; Stroeve and others, 2014), all of which are included within the PBDE. Polar bears are reliant on sea ice as a substrate to access marine mammal prey, and major changes in the availability of sea ice foraging habitat have been linked to declines in body condition, recruitment, survival, and abundance in the southern Beaufort Sea (Regehr and others, 2006; Rode and others, 2010). Thus the finding of worsening population outcomes through time is consistent with historical observations, although we note there is little data available from the Chukchi, Kara, and Laptev Seas subpopulations (Obbard and others, 2010). Recent data from the Chukchi Sea suggest that polar bears have maintained body condition and reproduction in response to initial levels of sea ice loss. Although we considered these data and included potential stability of female body condition in response to sea ice loss (30 percent probability of maintained body condition) over the long-term, the model outcomes suggested that polar bears in the PBDE will be the most sensitive to continued sea ice loss. 
The SIE also has experienced a trend of lengthening melt season (Gagnon and Gough, 2005). For example, polar bears in western Hudson Bay have been accustomed to spending upwards of 4 months on shore fasting each summer/autumn, when annual sea ice melts completely (Derocher and Stirling, 1990). However, over the last three decades the length of the melt season has increased by approximately 3 weeks and, similar to findings from the southern Beaufort Sea, there is evidence of adverse effects on polar bears (e.g., Rode and others, 2011). For example, reduced availability of sea ice in western Hudson Bay has been linked to observed declines in polar bear body mass, body condition, and survival (Stirling and others, 1999; Regehr and others, 2007). Further, energetic modeling predicted that 16 percent of adult males and females could die of starvation if the onshore fasting period lasts upwards of 5 months (Robbins and others, 2012). However, SIE future outcomes are characterized by greater uncertainty than PBDE outcomes. For example, in the Davis Strait subpopulation of the SIE there has been a marked increase in the abundance of harp seals concomitant with declines in sea ice availability (Department of Fisheries and Oceans, 2010), which has been posited as a factor contributing to an increase in the size of the subpopulation (Peacock, 2009). Thus, uncertainty in SIE outcomes might be attributed to the ameliorating effects of increased secondary prey availability in some areas as melt season lengthens.

Polar bear outcomes for the PBCE were similar to those from the SIE in terms of trend, but uncertainty of outcomes was slightly higher. This is most likely due to more modest projected changes in sea ice metrics and the lack of data on polar bears from this region. The PBCE region is characterized by heavy multi-year ice that accumulates via advection from the PBDE (Holland and others, 2006; Serreze and others, 2007). Advected ice tends to aggregate along coastlines (Stirling and others, 2011), which then provides functional connectivity between sea ice and terrestrial denning habitat, unlike in the PBDE. The maintenance of connectivity between sea ice and terrestrial habitat may contribute to the less dire trend in outcomes. The PBCE is comprised of the East Greenland, Queen Elizabeth, and northern Beaufort Sea subpopulations; survival and abundance data are available only for a portion of the northern Beaufort Sea subpopulation, where abundance through 2006 was considered to be stable (Stirling and others, 2011). The paucity of population and stressor data available from this ecoregion is reflected in the level of uncertainty in polar bear outcomes.

Normative outcomes for the AE were the most optimistic among the ecoregions, although also marked by the greatest amount of uncertainty. The AE, like the PBCE, is characterized by heavy multiyear ice that remains in the region year-round (Amstrup and others, 2008). As a result, projected changes to sea ice metrics are the most modest, and it is possible that, in the near term, thinning of the dense ice may actually improve the quality of foraging sea ice habitat (Arrigo and others, 2008). However, like the PBCE, there is relatively little data available on polar bear vital rates and stressors from the AE. Moreover, we only used $8 \mathrm{GCM}$ models to estimate future sea ice for the AE, which increased uncertainty in estimates of sea ice metrics. Nevertheless, the AE appeared to be the most resilient to changing environmental conditions and resisted transitioning to a dominant probability of "greatly decreased" until the end of the century and only under RCP 8.5. Our findings support those of Amstrup and others (2008) and Peacock and others (2015) that the AE is likely to serve as a long-term refugium for polar bears. 


\section{Effect of Stabilizing GHG Emissions}

Under RCP 8.5, the decline in all three sea ice metrics of importance to polar bears (total ice habitat, ice absence, and shelf distance) was hastened. Perhaps most importantly, this unabated emission pathway lengthened the duration of the melt season beyond the point (i.e., 5-6 months) at which extended fasting is predicted to lead to increased reproductive failure and starvation in polar bears (Molnar and others, 2011, 2014; Robbins and others, 2012). Not surprisingly, polar bear outcomes were more dire under RCP 8.5, with outcomes in three (PBDE, SIE, and PBCE) of the four ecoregions reaching a dominant state of "greatly decreased" by the early or mid-century mark. Stabilizing GHG emissions, by adhering to RCP 4.5 , generally decreased the probability that a given ecoregion transitioned into the "decreased" or "greatly decreased" outcome state by 8-11 percent. However, the PBDE, SIE, and PBCE still reached dominant probabilities of "greatly decreased" by the early or midcentury time periods under RCP 4.5.

Polar bear outcomes benefited most from keeping future GHG emissions consistent with those reflected in RCP 4.5. Amstrup and others (2010) came to a similar conclusion with the first generation model when comparing "aggressively mitigated" and "business as usual" emission scenarios derived from the CMIP3 GCM model set. That effort indicated that reduced radiative forcing with GHG mitigation resulted in greater retention of sea ice and less change to polar bear habitat, which increased the probability that polar bears could persist through the end of the century for all ecoregions. Our comparison between RCP 4.5 and 8.5 is conceptually similar-although RCP 4.5 is considered to represent a stabilization rather than abatement pathway because $\mathrm{CO}_{2}$ emissions plateau around 2040; RCP 8.5 represents a worst-case unabated pathway (Moss and others, 2010). While there are important differences in the approaches and data used in the first and second generation polar bear BN models (as described directly above and elsewhere), our qualitatively similar findings reinforce the importance of stabilizing atmospheric concentrations of $\mathrm{CO}_{2}$ to the long-term persistence of polar bears.

\section{Stressor Evaluation}

Ideally, influential stressors would have some degree of independence from climate-mediated changes to the environment, so that climate change is not always the ultimate cause of the interaction between polar bears and the stressors. Without some degree of decoupling, actions taken to mitigate those stressors are likely to prove ineffective because of the policy, social, and economic implications inherent to addressing rising GHG emissions. We do recognize that some stressors are likely somehow correlated or even causally linked, such as reduction in summer sea ice leading to increased shipping, tourism, and other marine-related anthropogenic stressors. Thus, our influence run analyses focused on stressors, individually and in reasonable combinations, that are of greatest concern to managers and span a spectrum from those that are relatively easy to manage (e.g., DLP kills) to those that are difficult or impossible to manage (e.g., overall sea ice conditions). None of the known and putative stressors we assessed appear to be independent from environmental change, thus potentially limiting the efficacy of mitigating anthropogenic stressors without mitigating GHG emissions.

Ice and Prey availability - "Overall sea ice conditions" exerted the most influence on polar bear population outcomes. Excepting the AE, sea ice projections under RCP 4.5 indicated that for the remaining ecoregions ice-free conditions were likely to exist for $2-6$ months by mid-century, and 5-9 months by the end of the century. Under RCP 8.5 , mid-century and end of century ice-free conditions were likely to last 3.5-7.5 and 7-11 months, respectively. In the model, the increasing duration of the ice-free period is most conspicuously manifested as a decline in overall sea ice conditions and habitat suitability. However, the most serious consequence of the lengthened ice-free period is the reduced 
availability of marine mammal prey. Changes in the ice-free duration may or may not be accompanied by changes in the abundance of marine prey. However, without the sea ice substrate, prey will be largely unavailable to bears (Stirling and Derocher, 1993). The energetic consequences of restricted prey access are not fully known, but observational and model-based estimates suggest that increased fasting will lead to declines in body condition, adult female and male mass, reproductive potential, and survival (e.g., Atkinson and Ramsay, 1995; Derocher and Stirling, 1995; Molnar and others, 2011; Robbins and others, 2012). These adverse consequences become more dire as the ice-free period lengthens beyond 4 months which, according to sea ice projections, is likely to occur for the majority of Arctic by midcentury (2045-2055) under RCP 8.5 and by late century (2070-2080) under RCP 4.5.

A secondary concern of the lengthening ice-free period is the resulting increase in the length of time bears spend on shore. Polar bears appear able to forage effectively over sea ice until ice concentration values dip below a threshold ranging from 30 to 50 percent (Stirling and others, 1999; Sahanatien and Derocher, 2012; Cherry and others, 2013). Below that threshold range, polar bears displace to alternative habitats, which can be sea ice, if available, or terrestrial habitat including barrier islands and the mainland. The primary concern with increased use of terrestrial habitat revolves around the potential for increased or prolonged exposure to anthropogenic stressors, including stressors that bears would not be exposed to if on the sea ice. For example, increased time spent on shore may increase the potential for human-polar bear interactions, which could then lead to conflict and an increased likelihood of mortality from "DLP" kills (Stirling and Derocher, 2012). Likewise, time spent on shore could serve to mediate exposure to industrial pollutants and infectious agents and parasites that bears would not be exposed to in a marine environment (Stirling and Derocher, 2012). Indeed, the hypothesized nexus between climate-mediated changes in sea ice characteristics and exposure to a greater array of stressors is a key consideration when attempting to identify which management actions are likely to be most effective.

Like "overall sea ice conditions," "marine prey base" was a highly influential stressor. Under a best-case scenario (i.e., where prey base conditions were maximized), elevated "marine prey base" resulted in a substantial reduction (as high as 51 percent) in the probability that a given ecoregion transitioned to a future state of decreased or greatly decreased. However, we note that while "marine prey base" is decoupled from sea ice metrics in our model, that does not reflect reality. In developing the conditional probability table for this node, we recognized that changes in primary and secondary prey abundance, as well as availability, were likely to occur as sea ice cover declines and physical characteristics change (e.g., Lydersen and Kovacs, 1999; Bluhm and Gradinger, 2008; Iacozza and Ferguson, 2014). At this time, available information is insufficient to quantify the linkage between sea ice conditions and polar bear prey abundance.

Other stressors - "Harvest" and "DLP" had influence on polar bear outcomes, although considerably less than "overall sea ice conditions" and "marine prey base." Minimizing the effect of harvest resulted in a 2-5 percent reduction in the probability of transitioning to decreased or greatly decreased states, while minimizing DLP resulted in a 1-3 percent reduction. There was no indication from the model of an additive effect of these two stressors. The influence run result from the best- and worst-case scenario for "event-driven mortality," which is informed by "harvest" and "DLP," resulted in a 3-6 percent reduction in the probabilities of decreased or greatly decreased outcome states. This finding, of no clear additive effect of different forms of mortality, could be due to several reasons. First, some polar bear harvest is opportunistic and may result from a DLP encounter. For example in the United States, polar bears killed as a result of DLP interactions are treated as harvested bears in the sense that they are considered a take to be counted against quota allotments (Schliebe, 1986). Second, there is very little information on the cause-specific mortality of polar bears. Amstrup and Durner 
(1995) found that 85 percent of the documented deaths of adult females were attributable to hunting, while 90 percent of documented losses of dependent young were attributable to sources other than hunting. Given the generally low survival of dependent young compared to subadults and adults (e.g., Regehr and others, 2006), we may be underestimating the extent to which other forms of mortality contribute to "event-driven mortality." More information on cause-specific mortality, particularly for dependent young, will be needed to know if that mortality is mostly driven by natural (e.g., starvation or extreme weather events) or anthropogenic stressors, and thus susceptible to management intervention.

The remaining stressors had little influence on polar bear outcomes at the ecoregional scale of our assessment (although they may play more salient roles locally). For example, minimizing the effect of pollutants (e.g., hydrocarbons and other persistent organic compounds) resulted in $\leq 2$ percent reduction in the probability of a decreased or greatly decreased outcome. Similarly, stressors that have the potential to result in sub-lethal disturbances, such as non-lethal human-polar bear interaction, resource extraction and exploration activity, shipping, and tourism had an even lesser influence on polar bear outcomes ( $<1$ percent). In both cases, the finding of minimal influence is likely due to a lack of information on population-level effects. Although there is substantial information characterizing exposure of polar bears to pollutants (e.g., Sonne and others, 2012), there is little information linking exposure to population vital rates. Also, sub-lethal stressor effects can be cumulative (Holmstrup and others, 2010) and given that some of these stressors are relatively new to the Arctic (e.g., shipping and tourism) they may not have reached a level of intensity that elicits a measurable response from polar bears. Conversely, some of those stressors may not actually affect polar bears. Clearly better information is needed to determine the influence these putative stressors are likely to have on polar bear populations, and the little resulting influence in our model in part is due to the current uncertainty in the extent and effects of such stressors.

\section{Manageability of Influential Stressors}

The most substantive positive effect on polar bear population outcomes resulted from improvement in the condition of sea ice habitat resulting from stabilized GHG emissions, followed by improved availability and accessibility of marine mammal prey. Improved sea ice habitat, alone, could reduce by about 50 percent the probability of polar bear population status in a given ecoregion reaching a state of decreased or greatly decreased. However, managing for improvements in sea ice habitat and marine mammal prey quality is a daunting challenge that will require a global policy solution and likely be years in the making. Because $\mathrm{CO}_{2}$ emissions accumulate over time, there will be a lag, likely on the order of several decades, between mitigation of emissions and meaningful stabilization of sea ice habitat loss (sensu Allen and Stocker, 2013).

By contrast, other stressors had substantially less influence on polar bear outcomes, but would be inherently more tractable to manage. We found no single stressor that can be targeted with the expectation of achieving an improvement in population outcomes comparable to improving sea ice conditions or marine prey availability. As evidenced by our wholistic "best management practices" influence runs, the best outcomes were reached when all non-sea ice stressor values were set to their minimum levels. However, implementing "best management practices" only reduced by about 10 percent the probability of an ecoregion reaching the decreased or greatly decreased state. Nevertheless, there is a fair amount of uncertainty in our population outcomes, and a 10 percent reduction in the likelihood of a population becoming decreased or greatly decreased may buy time to achieve mitigation of GHG emissions and arrest further sea ice habitat losses. 
The most influential stressors to polar bear populations were "overall sea ice conditions," "marine prey base," "hunting," and "DLP kills." Other stressors, such as "shipping," "tourism," and "oil and gas extraction activities" appeared to have little influence on population outcomes, mainly because of the paucity of information linking those factors to adverse effects on polar bears. As a result, we depicted considerable uncertainty in the probabilities of those stressor nodes. This highlights an important value of the BN approach: explicit representation of uncertainty (Marcot, 2012), which can then be used to direct further research efforts. Accordingly, research investigating the potential for lethal and sub-lethal effects of increased anthropogenic activity on polar bears would reduce uncertainty. Because such activities are fairly new to the Arctic, simulation-based approaches could be used until adequate field data exist to develop empirical models.

\section{Conclusion}

We developed a second generation model to evaluate which stressors were most likely to measurably affect future polar bear population outcomes. As in the first generation model, model outcomes, when projecting sea ice conditions using an ensemble of GCMs and holding other stressors unchanged, revealed a trend of progressively greater probabilities of polar bear population outcomes becoming decreased or greatly decreased by the end of the century. Although outcome uncertainty varied among ecoregions, we found that emissions under the unabated RCP 8.5 caused polar bears in most ecoregions to reach a dominant probability of decreased or greatly decreased about 25 years earlier than they would under the stabilized RCP 4.5.

Influence runs showed that model outcomes were driven primarily by changes to sea ice habitat and, to a lesser degree, by changes in prey abundance. These stressors are inherently difficult to manage because ultimately those changes are modulated by GHG emissions. Minimizing harvest and DLP kills had a comparatively small, but not trivial, effect. Because these stressors can be managed in situ, they are considerably more tractable from a management perspective. Minimizing other stressors offered little to modest improvement over minimizing just harvest and DLP. However, the effects of other stressors on polar bear vital rates are poorly understood, and we had to reflect that with relatively high degrees of uncertainty when parameterizing those input nodes. Thus, the low influence of those stressors could be attributed, in part, to our uncertainty about when they might be expressed and their impact on polar bear populations. Also, stressors with low influence outcomes in our model at the ecoregional scale may still have high influence more locally.

The long-term persistence of polar bears will require stabilizing the projected loss of sea ice habitat, which can best be achieved by maintaining GHG emissions consistent with or below the RCP 4.5 trajectory. By most estimates, it will take several decades for the effects of GHG mitigation to be realized via the recovery of sea ice habitat. In those intervening decades, the management of key stressors may serve to slow (but not halt or reverse) the transition of polar bear ecoregions to progressively more dire outcome states. Doing so could improve the prospects of their persistence until sea ice habitat is stable. 


\section{Acknowledgments}

This analysis is part of the U.S. Geological Survey’s Changing Arctic Ecosystems Initiative, supported by the Ecosystems Mission Area, with additional in-kind contributions from the U.S. Forest Service. Additional support was provided by the U.S. Fish and Wildlife Service, Region 7, Marine Mammals Management Office. We thank K. Laidre for providing expertise on polar bear ecology and for valuable insight throughout the course of this study. We thank the members of the U.S. Polar Bear Recovery Team, Science and Traditional Ecological Knowledge Working Group that provided feedback on model influence diagrams and structure. We are grateful for the helpful comments and suggestions from T. DeBruyn, J. Wilder, M. Runge, and D. Pierce-Williams at various stages in the development of this work. K. Oakley, S. Ban, and G. Wilhere provided comments on an earlier version of this manuscript that improved this final version.

\section{References Cited}

Aars, J., Lunn, N.J., and Derocher, A.E., eds., 2006, Polar bears-Proceedings of the 14th working Meeting of the IUCN/SSC Polar Bear Specialist Group, 20-24 June 2005, Seattle, Washington, USA: Gland, Switzerland, International Union for Conservation of Nature and Natural Resources, $189 \mathrm{p}$.

Allen, M.R., and Stocker, T.F., 2013, Impact of delay in reducing carbon dioxide emissions: Nature Climate Change, v. 4, p. 23-26, dio:10.1038/NCLIMATE2077.

Amstrup, S.C., Gardner, C., Meyers, K.C., and Oehme, F.W., 1989, Ethylene glycol (antifreeze) poisoning of a free-ranging polar bear: Veterinary and Human Toxicology, v. 3, p. 317-319.

Amstrup, S.C., and Durner, G.M., 1995, Survival rates of radio-collared female polar bears and their dependent young: Canadian Journal of Zoology, v. 73, p. 1,312-1,322.

Amstrup, S.C., McDonald, T.L., and Durner, G.M., 2004, Using satellite radiotelemetry data to delineate and manage wildlife populations, Wildlife Society Bulletin, v. 32, p. 661-679.

Amstrup, S.C., Durner, G.M., McDonald, T.L., and Johnson, W.R., 2006a, Estimating potential effects of hypothetical oil spills on polar bears: U.S. Geological Survey Open-File Report 2006-1337, 20 p.

Amstrup, S.C., Stirling, I., Smith, T.S., Perham, C., and Thiemann, G.W., 2006b, Recent observations of intraspecific predation and cannibalism among polar bears in the southern Beaufort Sea: Polar Biology, v. 29, p. 997-1,002.

Amstrup, S.C., Marcot, B.G., and Douglas, D.C., 2008, A Bayesian network modeling approach to forecasting the 21 st century worldwide status of polar bears, in DeWeaver, E.T., Bitz, C.M., and Tremblay, L-B., eds., Arctic sea ice decline-Observations, projections, mechanisms, and implications: Washington, D.C., American Geophysical Union Geophysical Monograph No. 180.

Amstrup, S.C., DeWeaver, E.T., Douglas, D.C., Marcot, B.G., Durner, G.M., Bitz, C.M., and Bailey, D.A., 2010, Greenhouse gas mitigation can reduce sea ice loss and increase polar bear persistence: Nature, v. 468, 955-960.

Andersen, M., Derocher, A.E., Wiig, Ø., and Aars, J., 2012, Polar bear (Ursus maritimus) maternity den distribution in Svalbard, Norway: Polar Biology, v. 35, p. 499-508.

Arrigo, K.R., van Dijken, G., and Pabi, S., 2008, Impact of a shrinking Arctic ice cover on marine prey primary production: Geophysical Research Letters, v. 35, doi:10.1029/2008GL035028.

Atkinson, S.N., and Ramsay, M.A., 1995, The effect of prolonged fasting on the body composition and reproductive success of female polar bears (Ursus maritimus): Functional Ecology, v. 9, p. 559-567. 
Barton, D.N., Kuikka, S., Varis, O., Uusitalo, L., Henriksen, H.J., Borsuk, M., de la Hera, A., Farmani, R., Johnson, S., and Linnell, J.D.C., 2012, Bayesian networks in environmental and resource management: Integrated Environmental Assessment and Management, v. 8, p. 418-429.

Bedoya, D., Manolakos, E.S., and Novotny, V., 2011, Characterization of biological responses under different environmental conditions-A hierarchical modeling approach: Ecological Modelling, v. 222, p. $532-545$.

Bluhm, B.A., and Gradinger, R., 2008, Regional variability in food availability for Arctic marine mammals: Ecological Applications, v. 18, S77-S96.

Born, E.W., Heilmann, A., Holm, L.K., and Laidre, K.L., 2011, Polar bears in Northwest Greenland: An interview survey about the catch and the climate: Copenhagen, Museum Tusculanum Press, $232 \mathrm{p}$.

Burek, K.A., Gulland, F.M.D., and O'Hara, T.M., 2008, Effects of climate change on Arctic marine mammal health: Ecological Applications, v. 18, S126-S134.

Cavalieri, D.J., Parkinson, C.L., Gloersen, P., and Zwally, H., 1996 (updated yearly), Sea ice concentrations from Nimbus-7 SMMR and DMSP SSM/I-SSMIS passive microwave data, northern hemisphere: Boulder, Colo., National Aeronautics and Space Administration Distributed Active Archive Center at the National Snow and Ice Data Center.

Cherry, S.G., Derocher, A., Thiemann, G.W., and Lunn, N.J., 2013, Migration phenology and seasonal fidelity of an Arctic marine predator in relation to sea ice dynamics: Journal of Animal Ecology, $\mathrm{v}$. 82, p. 912-921.

Clark, J.A., Hoekstra, J.M., Boersma, P.D., and Kareiva, P., 2002, Improving US Endangered Species Act recovery plans-Key findings and recommendations of the SCB recovery plan project: Conservation Biology, v. 16, p. 1,510-1,519.

Collins, M., Knutti, R., Arblaster, J., Dufresne, J.-L., Fichefet, T., Friedlingstein, P., Gao, X., Gutowski, W.J., Johns, T., Krinner, G., Shongwe, M., Tebaldi, C., Weaver, A.J., and Wehner, M., 2013, Longterm climate change-Projections, commitments and irreversibility, in Stocker, T.F., Qin, D., Plattner, G.-K., Tignor, M., Allen, S.K., Boschung, J., Nauels, A., Xia, Y., Bex, V., and Midgley, P.M., eds., Climate change 2013 - The Physical Science Basis. Contribution of Working Group I to the Fifth Assessment Report of the Intergovernmental Panel on Climate Change, Cambridge, United Kingdom and New York, Cambridge University Press.

Comiso, J.C., and Nishio, F., 2008, Trends in sea ice cover using enhanced and compatible AMSR-E, SSM/I, and SMMR data: Journal of Geophysical Research: Oceans, v. 113, p. 1,978-2,012.

Dai, L., Vorselen, D., Korolev, K.S., and Gore, J., 2012, Generic indicators for loss of resilience before a tipping point leading to population collapse: Science, v. 336, p. 1,175-1,177.

Darwiche, A., 2009, Modeling and reasoning with Bayesian networks: New York, Cambridge University Press, $560 \mathrm{p}$.

Department of Fisheries and Oceans, 2010, Current status of northwest Atlantic harp seals, Pagophilus groenlandicus: Ottawa, Canada, DFO Canadian Scientific Advisory Secretariat Science Advisory Report 2009/074, 15 p.

Derocher, A.E., and Stirling, I., 1990, Distribution of polar bears (Ursus maritimus) during the ice-free period in western Hudson Bay: Canadian Journal of Zoology, v. 68, p. 1,395-1,403.

Derocher, A.E., and Stirling, I., 1991, Oil contamination of polar bears: Polar Record, v. 27, p. 56-57.

Derocher, A.E., Andriashek, D., and Stirling, I., 1993, Terrestrial foraging by polar bears during the icefree period in western Hudson Bay: Arctic, v. 46, p. 251-254.

Derocher, A.E., and Stirling, I., 1995, Temporal variation in reproduction and body mass of polar bears in western Hudson Bay: Canadian Journal of Zoology, v. 73, p. 1,657-1,665. 
Derocher, A.E., and Wiig, Ø., 1999, Infanticide and cannibalism of juvenile polar bears (Ursus maritimus) in Svalbard: Arctic, v. 52, p. 307-310.

Derocher, A.E., Andersen, M., Wiig, Ø., Aars, J., Hansen, E., and Biuw, M., 2011, Sea ice and polar bear den ecology at Hopen Island, Svalbard: Marine Ecology Press Series, v. 441, p. 273-279.

Derocher, A.E., Aars, J., Amstrup, S.C., Cutting, A., Lunn, N.J., Molnár, P.K., Obbard, M.E., Stirling, I., Thiemann, G.W., Vongraven, D., Wiig, Ø., and York, G., 2013, Rapid ecosystem change and polar bear conservation: Conservation Letters, v. 6, p. 368-375.

Drake, J. M., and Griffen, B.D., 2010, Early warning signals of extinction in deteriorating environments: Nature, v. 467, p. 456-459.

Durner, G.M., Douglas, D.C., Nielson, R.M., Amstrup, S.C., McDonald, T.L., Stirling, I., Mauritzen, M., Born, E.W., Wiig, O., DeWeaver, E., Serreze, M.C., Belikov, S., Holland, M., Maslanik, J.A., Aars, J., Bailey, D.A., and Derocher, A.E., 2009, Predicting 21st-century polar bear habitat distribution from global climate models: Ecological Monograph, v. 79, p. 25-58.

Ebinger, C.K., and Zambetakis, E., 2009, The geopolitics of Arctic melt: International Affairs, v. 85, p. 1,215-1,232.

Ferguson, S.H., Stirling, I., and McLoughlin, P., 2005, Climate change and ringed seal (Phoca hispida) recruitment in western Hudson Bay: Marine Mammal Science, v. 21, p. 121-135.

Ferguson, S.H., Taylor, M.K., and Messier, F., 2000, Influence of sea ice dynamics on habitat selection by polar bears: Ecology, v. 81, p. 761-772.

Fischbach, A.S., Amstrup, S.C., and Douglas, D.C., 2007, Landward and eastward shift of Alaskan polar bear denning associated with recent sea ice changes: Polar Biology, v. 30, 1,395-1,405.

Gagnon, A.S., and Gough, W.A., 2005, Trends in the dates of ice freeze-up and breakup over Hudson Bay, Canada: Arctic, v. 58, p. 370-382.

Gautier, D.L., Bird, K.J., Charpentier, R.R., Grantz, A., Houseknecht, D.W., Klett, T.R., Moore, T.E., Pitman, J.K., Schenk, C.J., Schuenemeyer, J.H., Sorensen, K., Tennyson, M.E., Valin, Z.C., and Wandrey, C.J., 2009, Assessment of undiscovered oil and gas in the arctic: Science, v. 324, p. 1,1751,179 .

Guntenspergen, G.R., ed., 2014, Application of threshold concepts in natural resource decision making: New York, Springer, 324 p.

Herreman, J., and Peacock, E, 2013, Polar bear use of a persistent food subsidy_-Insights from noninvasive genetic sampling in Alaska: Ursus, v. 24, p. 148-163.

Holland, M.M., Bitz, C.M., and Tremblay, B., 2006, Future abrupt reductions in the summer Arctic sea ice: Geophysical Research Letters, v. 33, L23503, doi:10.1029/2006GL028024.

Holmstrup, M., Bindesbøl, A.M., Oostingh, G.J., Duschl, A., Scheil, V., Köhler, H.R., Loureiro, S., Soares, A.M.V.M., Ferreira, A.L.G., Keinle, C., Gerhardt, A., Laskowski, R., Kramarz, P.E., Bayley, M., Svendsen, C., and Spurgeon, D.J., 2010, Interactions between effects of environmental chemicals and natural stressors - A review: Science of the Total Environment, v. 408, p. 3,746-3,762.

Iacozza, J., and Ferguson, S.H., 2014, Spatio-temporal variability of snow over sea ice in western Hudson Bay, with reference to ringed seal pup survival: Polar Biology, v. 37, p. 817-832.

Irvine R.J., Corbishley, H., Pilkington, J.G., and Albon, S.D., 2006, Low-level parasitic worm burdens may reduce body condition in free-ranging red deer (Cervus elaphus): Parasitology, v. 133, p. 465475.

Iverson, S.A., Gilchrsit, H.G., Smith, P.A., Gaston, A.J., and Forbes, M.R., 2014, Longer ice-free seasons increase the risk of nest predation by polar bears for colonial breeding birds in the Canadian Arctic: Proceedings of the Royal Society B: Biological Sciences, v. 281, doi:10.1098/rspb2013.3128. 
Jay, C.V., Marcot, B.G., and Douglas, D.C., 2011, Projected status of the Pacific walrus (Odobenus rosmarus divergens) in the twenty-first century: Polar Biology, v. 34, p. 1,065-1,084.

Jensen F.V., and Nielsen, T.D., 2007, Bayesian networks and decision graphs (information science and statistics): New York, Springer, 448 p.

Johnson S., Marker, L., Mengersen, K., Gordon, C.H., Melzheimer, J., Schmidt-Kunzel, A., Nghikembua, M., Fabiano, E., Henghali, J., and Wachter, B., 2013, Modeling the viability of the freeranging cheetah population in Namibia-An object-oriented Bayesian network approach: Ecosphere, v. 4, p. 90, http://dx.doi.org/10.1890/ES12-00357.1.

Kelly, B.P., Bengtson, J.L., Boveng, P.L., Cameron, M.F., Dahle, S.P., Jansen, J.K., Logerwell, E.A., Overland, J.E., Sabine, C.L., Waring, G.T., and Wilder, J.M., 2010, Status review of the ringed seal (Phoca hispida): National Oceanic Atmospheric Administration Technical Memo, NMFS-AFSC-212, $250 \mathrm{p}$.

Kirk, C.M., Amstrup, S., Swor, R., Holcomb, D., and O’Hara, T.M., 2011, Morbillivirus and Toxoplasma exposure and association with hematological parameters for southern Beaufort Sea polar bears: potential response to infectious agents in a sentinel species: EcoHealth, v. 7, p. 321-331.

Kovacs, K.M., Lydersen, C., Overland, J.E., and Moore, S.E., 2011, Impacts of changing sea-ice conditions on Arctic marine mammals: Marine Biodiversity, v. 41, p. 181-194.

Kovacs, K.M., Aguilar, A., Aurioles, D., Burkanov, V., Campagna, C., Gales, N., Gelatt, T., Goldsworthy, S.D., Goodman, S.J., Hofmeyr, G.J.G., Harkonen, T., Lowry, L., Lydersen, C., Schipper, J., Sipilia, T., Southwell, C., Stuart, S., Thompson, D., and Trillmich, F., 2012, Global threats to pinnipeds: Marine Mammal Science, v. 28, p. 414-436.

Knutti, R., 2008, Should we believe model predictions of future climate change?: Philosophical Transactions of the Royal Society A, v. 366, p. 4,647-4,664.

Knutti, R., Furrer, R., Tebaldi, C., Cermak, J., and Meehl, G.A., 2010, Challenges in combining projections from multiple climate models: Journal Climate, v. 23, p. 2,739-2,758.

Lawler, J.J., Campbell, S.P., Guerry, A.D., Kolozsvary, M.B., O’Connor, R.J., and Seward, L.C.N., 2002, The scope and treatment of threats in endangered species recovery plans: Ecological Applications, v. 12, p. 663-667.

Lindsay, R.W., and Zhang, J., 2005, The thinning of Arctic sea ice, 1988-2003-Have we passed a tipping point?: Journal of Climate, v. 18, p. 4,879-4,894.

Love, O.P., McGowan, P.O., and Sheriff, M.J., 2013, Maternal adversity and ecological stressors in natural populations - The role of stress axis programming in individuals, with implications for populations and communities: Functional Ecology, v. 27, p. 81-92.

Lowry, L., and Boveng, P., 2009, Ribbon seal, in Perrin, W.F., Wursig, B., and Thewissen, J.G.M., eds., Encyclopedia of marine mammals (2nd ed.): San Diego, Academic Press, p. 955-958.

Lunn, N.J., and Stenhouse, G.B., 1985, An observation of possible cannibalism by polar bears (Ursus maritimus): Canadian Journal of Zoology, v. 63, p. 1,516-1,517.

Lydersen, C., and Kovacs, K.M., 1999, Behaviour and energetics of ice-breeding, North Atlantic phocid seals during the lactation period: Marine Ecology Progress Series, v. 187, p. 265-281.

Ma, J., Hung, H., Tian, C., and Kallenborn, R., 2011, Revolatilization of persistent organic pollutants in the Arctic induced by climate change: Nature Climate Change, v. 1, p. 255-260.

Mahoney, A.R., Eicken, H., Shapiro, L.H., Gens, R., Heinrichs, T., Meyer, F.J., and Gaylord, A.G., 2012, Mapping and characterization of recurring spring leads and landfast ice in the Beaufort and Chukchi Seas: Anchorage, Alaska, U.S. Bureau of Ocean Energy Management, Alaska Region, OCS Study BOEM 2012-067, p. 179. 
Marcot, B.G., Holthausen, R.S., Raphael, M.G., Rowland, M.M., and Wisdom, M.J., 2001, Using Bayesian belief networks to evaluate fish and wildlife population viability under land management alternatives from an environmental impact statement: Forest Ecology and Management, v. 153, p. 2942.

Marcot, B.G., Steventon, J.D., Sutherland, G.D., and McCann, R.K., 2006, Guidelines for developing and updating Bayesian belief networks applied to ecological modeling and conservation: Canadian Journal of Forest Research, v. 36, p. 3,063-3,074.

Marcot, B.G., 2007, Biodiversity and the lexicon zoo: Forest ecology and management, v. 246, p. 4-13. Marcot, B.G., 2012, Metrics for evaluating performance and uncertainty of Bayesian network models: Ecological Modelling, v. 230, p. 50-62.

Martin, T.G., Burgman, M.A., Filder, F., Kuhnert, P.M., Low-Choy, S., McBride, M., and Mengersen, K., 2012, Eliciting expert knowledge in conservation science: Conservation Biology, v. 26, p. 29-38. Massonnet, F., Fichefet, T., Goosse, H., Bitz, C., Philippon-Berthier, G., Holland, M., and Barriat, P.-Y, 2012, Constraining projections of summer Arctic sea ice: The Cryosphere, v. 6, p. 1,383-1,394.

McKinney, M.A., Stirling, I., Lunn, N.J., Peacock, E., and Letcher, R.J., 2010, The role of diet on longterm concentration and pattern trends of brominated and chlorinated contaminants in western Hudson Bay polar bears, 1991-2007: Science of the Total Environment, v. 408, p. 6,210-6,222.

Meehl, G.A., Covey, C., Delworth, T., Latif, M., McAvaney, B., Mitchell, J.F.B., Stouffer, R.J., and Taylor, K.E., 2007, The WCRP CMIP3 multimodel dataset-A new era in climate change research: Bulletin of the American Meteorological Society, v. 88, p. 1,383-1,394.

Meinshausen, M., Smith, S.J., Clavin, K., Daniel, J.S., Kainuma, M.L.T., Lamarque, J.-F., Matsumoto, K., Montzka, S.A., Raper, S.C.B., Riahi, K., Thomson, A., Velders, G.J.M., and van Vuuren, D.P.P., 2011, The RCP greenhouse gas concentrations and their extensions from 1765 to 2300: Climatic Change, v. 109, p. 213-241.

Miller, A.W., and Ruiz, G.M., 2014, Arctic shipping and marine invaders: Nature Climate Change, v. 4, p. 413-416.

Møller, A.P., Erritzøe, J., and Saino, N., 2003, Seasonal changes in immune response and parasite impact on hosts: The American Naturalist, v. 161, p. 657-671.

Molnar, P.K., Derocher, A.E., Klanjscek, T., and Lewis, M.A., 2011, Predicting climate change impacts on polar bear litter size: Nature Communications, v. 2, p. 186.

Molnár, P.K., Derocher, A.E., Thiemann, G.W., and Lewis, M.A., 2010, Predicting survival, reproduction and abundance of polar bears under climate change: Biological Conservation, v. 143, p. $1,612-1,622$.

Molnár, P.K., Derocher, A.E., Thiemann, G.W., and Lewis, M.A., 2014, Corrigendum to "Predicting survival, reproduction and abundance of polar bears under climate change" (Biological Conservation 143, [2010] 1612-1622): Biological Conservation, v. 177, p. 230-231, http://dx.doi.org/10.1016/j.biocon.2014.07.001.

Morgan, M.G., and Henrion, M., 1990, Uncertainty-A guide to dealing with uncertainty in quantitative risk and policy analysis: New York, Cambridge University Press, 344 p.

Moore, S.E., and Huntington, H.P., 2008, Arctic marine mammals and climate change-Impacts and resilience: Ecological Applications, v. 18, S157-S165.

Moss, R.H., Edmonds, J.A., Hibbard, K.A., Manning, M.R., Rose, S.K., van Vurren, D.P., Carter, T.R., Emori, S., Kainuma, M., Kram, T., Meehl, G.A., Mitchell, J.F.B., Nakicenovic, M., Riahi, K., Smith, S.J., Stouffer, R.J., Thomson, A.M., Weyant, J.P., and Wilbanks, T.J., 2010, The next generation of scenarios for climate change research and assessment: Nature, v. 463, p. 747-756. 
Murphy, J.M., Sexton, D.M., Barnett, D.N., Jones, G.S., Webb, M.J., Collins, M., and Stainforth, D.A., 2004, Quantification of modelling uncertainties in a large ensemble of climate change simulations: Nature, v. 430, p. 768-772.

Obbard, M.E., Cattet, M.R., Moody, T., Walton, L.R., Potter, D., Inglis, J., and Chenier, C., 2006, Temporal trends in the body condition of southern Hudson Bay polar bears: Ontario Ministry of Natural Resources, Applied Research and Development Branch, Sault Ste. Marie, Canada, Climate Change Research Information Note 3, p. 1-8.

Obbard, M.E., Thiemann, G.W., Peacock, E., and DeBruyn, T.D., eds., 2010, Polar bears-Proceedings of the 15th working meeting of the IUCN/SSC Polar Bear Specialist Group, Copenhagen, Denmark, 29 June-3 July 2009 (Occasional Paper of the IUCN Species Survival Commission): Gland,

Switzerland, International Union for Conservation of Nature and Natural Resources, $235 \mathrm{p}$.

Overland, J.E., and Wang, M., 2013, When will the Arctic be nearly sea ice free? Geophysical Research Letters, v. 40, p. 2,097-2,101.

Ovsyanikov, N.G., and Menyushina, I.E., 2010, Number, condition, and activity of polar bears on Wrangel Island during ice free autumn seasons of 2005-2009, Proceedings of the Marine Mammals of the Holarctic, 445-450.

Peacock, E., 2009, Davis Strait polar bear population inventory-Final report: Government of Igloolik, Nunavut, Canada, Department of Environment Report.

Peacock, E., Taylor, M.K., Laake, J., and Stirling, I., 2013, Population ecology of polar bears in Davis Strait, Canada and Greenland: Journal of Wildlife Management, v. 77, p. 463-476.

Peacock, E., Sonthsagen, S.A., Obbard, M.E., Boltunov, A., Regehr, E.V., Ovsyanikov, O., Aars, J., Atkinson, S.A., Sage, G.K., Hope, A.G., Zeyl, E., Bachmann, L., Ehrich, D., Scribner, K.T., Amstrup, S.C., Belikov, S., Born, E., Derocher, A.E., Stirling, I., Taylor, M.K., Wiig, Ø., Paetkau, D., and Talbot, S.L., 2015, Implications of the circumpolar genetic structure of polar bears for their ecology, evolution and conservation in a rapidly warming Arctic, PLoS One.

Perovich, D.K., Jones, K.F., Light, B., Eicken, H., Markus, T., Stroeve, J., and Lindsay, R., 2011, Solar partitioning in a changing Arctic sea-ice cover: Annals of Glaciology, v. 52, p. 192-196.

Peters, G.P., Nilssen, T.B., Lindholt, L., Eide, M.S., Glomsrød, S., Eide, L.I., and Fuglestvedt, J.S., 2011, Future emissions from shipping and petroleum activities in the Arctic: Atmospheric Chemistry and Physics, v. 11, p. 5,305-5,320.

Peterson, C.H., Rice, S.D., Short, J.W., Esler, D., Bodkin, J.L., Ballachey, B.E., and Irons, D.B., 2003, Long-term ecosystem response to the Exxon Valdez oil spill, Science, 320, 2082-2086.

Pilfold, N.W., Derocher, A.E., Stirling, I., Richardson, E., and Andriashek, D., 2012, Age and sex composition of seals killed by polar bears in the eastern Beaufort Sea: PLoS One, doi:10.1371/journal.pone.0041429.

Pioz, M., Loison, A., Gauthier, D., Gibert, P., Jullien, J. M., Artois, M., and Gilot-Fromont, E., 2008, Diseases and reproductive success in a wild mammal-Example in the alpine chamois: Oecologia, v. 155, p. 691-704.

Pollino, C.A., Woodberry, O., Nicholson, A., Korb, K., and Hart, B.T., 2007, Parameterisation and evaluation of a Bayesian network for use in an ecological risk assessment: Environmental Modelling and Software, v. 22, p. 1,140-1,152.

Polyak, L., Alley, R.B., Andrews, J.T., Brigham-Grette, J., Cronin, T.M., Darby, D.A., Dyke, A.S., Fitzpatrick, J.J., Funder, S., Holland, M., Jennings, A.E., Miller, G.H., O’Regan, M., Savelle, J., Serreze, M., St. John, K., White, J.W.C., and Wolff, E., 2010, History of sea ice in the Arctic: Quaternary Science Reviews, v. 29, p. 1,757-1,778. 
Rah, H., Chomel, B.B., Follman, E.H., Kasten, R.W., Hew, C.H., Farver, T.B., Garner, G.W., and Amstrup, S.C., 2005, Serosurvey of selected zoonotic agents in polar bears (Ursus maritimus): Veterinary Record, v. 156, p. 7-13.

Regehr, E.V., Amstrup, S.C., and Stirling, I., 2006, Polar bear population status in the southern Beaufort Sea: U.S. Geological Survey Open-File Report 2006-1337, 20 p.

Regehr, E.V., Lunn, N.J., Amstrup, S.C., and Stirling, I., 2007, Effects of earlier sea ice breakup on survival and population size of polar bears in western Hudson Bay: The Journal of Wildlife Management, v. 71, p. 2,673-2,683.

Regehr, E.V., Hunter, C.M., Caswell, H., Amstrup, S.C., and Stirling, I., 2010, Survival and breeding of polar bears in the southern Beaufort Sea in relation to sea ice: Journal of Animal Ecology, v. 79, p. 117-127.

Richardson, E., Stirling, I., and Hik, D.S., 2005, Polar bear (Ursus maritimus) maternity denning habitat in western Hudson Bay-A bottom-up approach to resource selection functions: Canadian Journal of Zoology, v. 83, p. 860-870.

Robbins, C.T., Lopez-Alfaro, C., Rode, K.D., Tøien, Ø., and Nelson, L.O., 2012, Hibernation and seasonal fasting in bears - The energetic costs and consequences for polar bears: Journal of Mammalogy, v. 93, p. 1,493-1,503.

Rode, K.D., Amstrup, S.C., and Regehr, E.V., 2010, Reduced body size and cub recruitment in polar bears associated with sea ice decline: Ecological Applications, v. 20, p. 768-782.

Rode, K.D., Peacock, E., Taylor, M., Stirling, I., Born, E.W., Laidre, K.L., and Wiig, Ø., 2011, A tale of two polar bear populations: ice habitat, harvest, and body condition: Population Ecology, v. 54, no. 1, doi:10.1007/s10144-011-0299-9.

Rode, K.D., Regehr, E.V., Douglas, D.C., Durner, G., Derocher, A.E., Thiemann, G.W., and Budge, S.M., 2014, Variation in the response of an Arctic top predator experiencing habitat loss: feeding and reproductive ecology of two polar bear populations: Global Change Biology, v. 20, no. 1, p. 76-88, doi:10.1111/gcb.12339.

Rogers, T.S., Walsh, J.E., Rupp, T.S., Brigham, L.W., and Sfraga, M., 2013, Future Arctic marine access-Analysis and evaluation of observations, models, and projections of sea ice: The Cryosphere, v. 7, p. 321-332.

Runge, M.C., Sanders-Reed, C.A., Langtimm, C.A., and Fonnesbeck, C.J., 2007, A quantitative threats analysis for the Florida manatee (Trichechus manatus latirostris): U.S. Geological Survey Open-File Report 2007-1086, 34 p.

Sahanatien, V., and Derocher, A.E., 2012, Monitoring sea ice habitat fragmentation for polar bear conservation: Animal Conservation, v. 15, p. 397-406.

Schliebe, S.L., 1986, Alaska polar bear native subsistence harvest, in Proceedings of the Ninth Working Meeting of the IUCN/SSC Polar Bear Specialist Group, Gland, Switzerland: Gland, Switzerland, International Union for Conservation of Nature and Natural Resources, p. 117-131.

Schliebe, S., Rode, K.D., Gleason, J.S., Wilder, J., Proffitt, K., Evans, T.J., and Miller, S., 2008, Effects of sea ice extent and food availability on spatial and temporal distribution of polar bears during the fall open-water period in the Southern Beaufort Sea: Polar Biology, v. 31, p. 999-1,010.

Schultz, C.B., and Gerber, L.R., 2002, Are recovery plans improving with practice?: Ecological Applications, v. 12, p. 641-647.

Serreze, M.C., Holland, M.M., and Stroeve, J. 2007, Perspectives on the Arctic's shrinking sea-ice cover: Science, v. 315, p. 1,533-1,536.

Sheriff, M.J., Krebs, C.J., and Boonstra, R., 2009, The sensitive hare: sublethal effects of predator stress on reproduction in snowshoe hares: Journal of Animal Ecology, v. 78, p. 1,249-1,258. 
Sheriff, M.J., and Love, O.P., 2013, Determining the adaptive potential of maternal stress: Ecology Letters, v. 16, p. 271-280.

Shimada, K., Kamoshida, T., Itoh, M., Nishino, S., Carmack, E., McLaughlin, F., Zimmerman, S., and Proshutinsky, A., 2006, Pacific Ocean inflow-Influence on catastrophic reduction of sea ice cover in the Arctic Ocean: Geophysical Research Letters, v. 33, doi:10.1029/2005GL025624.

Smit, M.G., Jak, R.G., Rye, H., Frost, T.K., Singsaas, I., and Karman, C.C., 2008, Assessment of environmental risks from toxic and nontoxic stressors-A proposed concept for a risk-based management tool for offshore drilling discharges: Integrated Environmental Assessment and Management, v. 4, p. 177-183.

Smith, L.C., and Stephenson, S.R., 2013, New Trans-Arctic shipping routes navigable by midcentury: Proceedings of the National Academy of Sciences, v. 110, p. 4,871-4,872.

Smith, P.A., Elliott, K.H., Gaston, A.J., and Gilchrist, H.G., 2010, Has early ice clearance increased predation on breeding birds by polar bears?: Polar Biology, v. 33, p. 1,149-1,153.

Sonne, C., Letcher, R.J., Bechshøft, T.Ø., Rigét, F.F., Muir, D.C., Leifsson, P.S., Born, E.W., Hyldstrup, L., Basu, N., Kirkegaard, M., and Dietz, R., 2012, Two decades of biomonitoring polar bear health in Greenland-A review: Acta Veterinaria Scandinavica, v. 54, S15.

Stephenson, S.R., Smith, L.C., Brigham, L.W., and Agnew, J.A., 2013, Projected 21st-century changes to Arctic marine access: Climatic Change, v. 118, p. 885-899.

Stirling, I., and Archibald, W.R., 1977, Aspects of predation of seals by polar bears: Journal of the Fisheries Board of Canada, v. 34, p. 1,126-1,129.

Stirling, I., and Derocher, A.E., 1993, Possible impacts of climatic warming on polar bears: Arctic, v. 46, p. 240-245.

Stirling, I., and Derocher, A.E., 2012, Effects of climate warming on polar bears-A review of the evidence: Global Change Biology, v. 18, p. 2,694-2,706.

Stirling, I., Lunn, N.J., and Iacozza, J., 1999, Long-term trends in the population ecology of polar bears in western Hudson Bay in relation to climatic change: Arctic, v. 52, p. 294-306.

Stirling, I., McDonald, T.L., Richardson, E.S., Regehr, E.V., and Amstrup, S.C., 2011, Polar bear population status in the northern Beaufort Sea, Canada, 1971-2006: Ecological Applications, v. 21, p. 859-876.

Stirling, I., and Parkinson, C.L., 2006, Possible effects of climate warming on selected populations of polar bears (Ursus maritimus) in the Canadian Arctic: Arctic, v. 59, p. 261-275.

Stirling, I., Richardson, E., Thiemann, G.W., and Derocher, A.E., 2008, Unusual predation attempts of polar bears on ringed seals in the southern Beaufort Sea: possible significance of changing spring ice conditions: Arctic, v. 61, p. 14-22.

Stroeve, J.C., Markus, T., Boisvert, L., Miller, J., and Barrett, A., 2014, Changes in Arctic melt season and implications for sea ice loss: Geophysical Research Letters, v. 41, p. 1,216-1,225.

Taylor, M.K., Akeeagok, S., Andriashek, D., Barbour, W., Born, E.W., Calvert, W., Cluff, H.D., Ferguson, S., Laake, J., Rosing-Asvid, A., Stirling, I., and Messier, F., 2001, Delineating Canadian and Greenland polar bear (Ursus maritimus) populations by cluster analysis of movements: Canadian Journal of Zoology, v. 79, p. 690-709.

Taylor, K.E., Stouffer, R.J., and Meehl, G.A., 2012, An overview of CMIP5 and the experiment design: Bulletin of the American Meteorological Society, v. 93, p. 485-498, doi:10.1175/BAMS-D11-00094.1.

Thiemann, G.W., Iverson, S.J., and Stirling, I., 2008, Polar bear diets and arctic marine food websInsights from fatty acid analysis: Ecological Monographs, v. 78, p. 591-613. 
Towns, L., Derocher, A.E., Stirling, I., Lunn, N.J., and Hedman, D., 2009, Spatial and temporal patterns of problem polar bears in Churchill, Manitoba: Polar Biology, v. 32, p. 1,529-1,537.

U.S. Fish and Wildlife Service, 2008, Endangered and threatened wildlife and plants-12-month petition finding and proposed rule to list the polar bear (Ursus maritimus) as threatened throughout its range: Federal Register, v. 72, p. 1,064-1,099.

van Vuuren, D.P., Edmonds, J., Kainuma, M., Riahi, K., Thomson, A., Hibbard, K., Hurtt, G.C., Kram, T., Krey, V., Lamarque, J.-F., Masui, T., Meinshausen, M., Nakicenovic, N., Smith, S.J., and Rose, S.K., 2011, The representative concentration pathways-An overview: Climatic Change, v. 109, p. 531, doi:10.1007/s10584-011-0148-z.

Vongraven, D., Aars, J., Amstrup, S., Atkinson, S.N., Belikov, S., Born, E.W., DeBruyn, T.D., Dreocher, A.E., Durner, G., Gill, M., Lunn, N., Obbard, M.E., Omelak, J., Peacock, E., Richardson, E., Sahanatien, V., and Wiig, Ø., 2012, A circumpolar monitoring framework for polar bears: Ursus, v. 23(sp2), p. 1-66.

Wang, M., and Overland, J.E., 2009, A sea ice free summer Arctic within 30 years?: Geophysical Research Letters, v. 36, doi:10.1029/2009GL037820.

Wang, M., and Overland, J.E., 2013a, Sea ice characteristics as simulated by CMIP5 models, Abstract GC43D-1078, presented at 2013 Fall Meeting, American Geophysical Union, San Francisco, California, December 9-13, 2013.

Wang, M., and Overland, J.E., 2013b, A sea ice free summer Arctic within 30 years-An update from CMIP5 models: Geophysical Research Letters, v. 39, doi:10.1029/2012GL052868.

Weber, D.S., Van Coeverden De Groot, P.J., Peacock, E., Schrenzel, M., Perez, D.A., Thomas, S., Shelton, J.M., Else, C.K., Darby, L.L., Acosta, L., Harris, C., Youngblood, J., Boag, P., and Desalle, R., 2013, Low MHC variation in the polar bear-Implications in the face of Arctic warming?: Animal Conservation, v. 16, p. 671-683.

Wielgus J., Gonzalez-Suarez, M., Aurioles-Gamboa, D., and Gerber, L.R., 2008, A noninvasive demographic assessment of sea lions based on stage-specific abundances: Ecological Applications, v. 18 , p. $1,287-1,296$. 
Table 1. The 13 general circulation models (GCM) used in this study, and the models' country and institute of origin.

[The 13 models were selected from among all CMIP5 models based on recommendations by Wang and Overland (2013a, 2013b) and Massonnet and others (2012); denoted with "W" or "M", respectively. Only 8 models had sufficient spatial resolution for analyses in the Archipelago Ecoregion ("Y")]

\begin{tabular}{lllll}
\hline \multicolumn{1}{c}{ Model } & \multicolumn{1}{c}{ Country } & \multicolumn{1}{c}{ Institute } & Selection & Archipelago \\
\hline ACCESS1.0 & Australia & ${ }^{1}$ CISRO-BOM & $\mathrm{W}, \mathrm{M}$ & \\
ACCESS1.3 & Australia & CISRO-BOM & $\mathrm{W}, \mathrm{M}$ & \\
CCSM4 & USA & ${ }^{2}$ NCAR & $\mathrm{W}$ & $\mathrm{Y}$ \\
CESM1-CAM5.1 & USA & ${ }^{3}$ NSF-DOE-NCAR & $\mathrm{W}$ & $\mathrm{Y}$ \\
EC-EARTH & European Center & ${ }^{4}$ EC-Earth Consortium & $\mathrm{W}$ & $\mathrm{Y}$ \\
GFDL-CM3 & USA & ${ }^{5}$ NOAA GFDL & $\mathrm{M}$ & $\mathrm{Y}$ \\
HadGEM2-AO & UK & ${ }^{6}$ MOHC & $\mathrm{W}$ & $\mathrm{Y}$ \\
HadGEM2-CC & UK & MOHC & $\mathrm{W}$ & $\mathrm{Y}$ \\
HadGEM2-ES & UK & MOHC & $\mathrm{W}$ & $\mathrm{Y}$ \\
IPSL-CM5A-MR & France & ${ }^{7}$ IPSL & $\mathrm{M}$ & \\
MIROC-ESM & Japan & ${ }^{8}$ AORI-NIES-JAMSTEC & $\mathrm{W}$ & \\
MIROC-ESM-CHEM & Japan & AORI-NIES-JAMSTEC & $\mathrm{W}$ & \\
MPI-ESM-MR & Germany & ${ }^{9}$ MPI & $\mathrm{W}, \mathrm{M}$ & $\mathrm{Y}$ \\
\hline
\end{tabular}

${ }^{1}$ Commonweath Scientific and Industrial Research Organization-Bureau of Meteorology.

${ }^{2}$ National Center for Atmospheric Research.

${ }^{3}$ National Science Foundation-Department of Energy-National Center for Atmospheric Research.

${ }^{4}$ European Center-Earth Consortium.

${ }^{5}$ National Oceanic and Atmospheric Administration-Geophysical Fluid Dynamics Laboratory.

${ }^{6}$ Met Office Hadley Center.

${ }^{7}$ Institut Pierre Simon LaPlace.

${ }^{8}$ Atmosphere and Ocean Research Institute (University of Toyko)-National Institute for Environmental Studies-Japan Agency for MarineEarth Science and Technology.

${ }^{9}$ Max Planck Institute. 


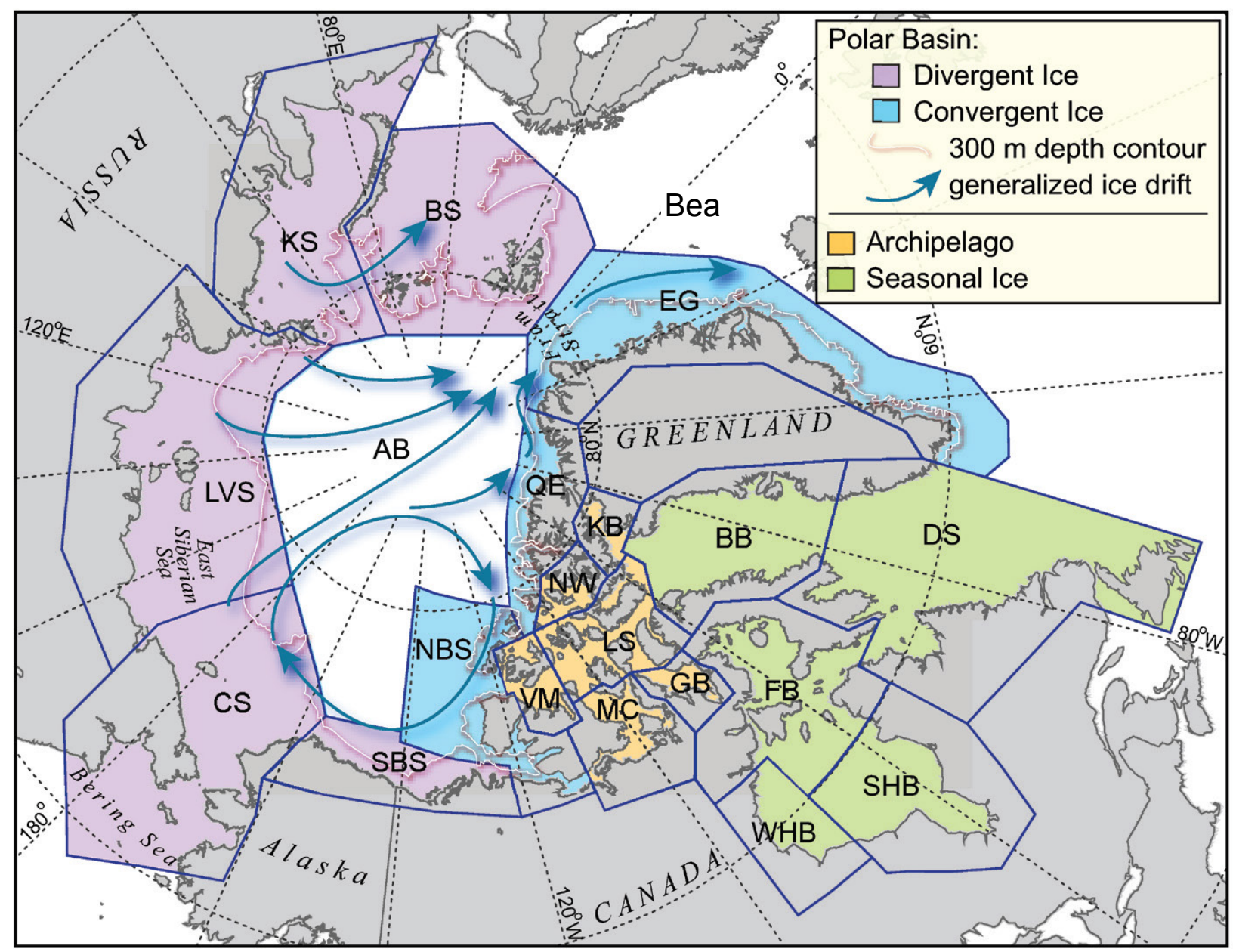

Figure 1. Map of the four polar bear ecoregions as defined by Amstrup and others (2008). The map includes a 300 $\mathrm{m}$ bathymetry contour denoting where the break in the continental shelf occurs, and a depiction of seasonal patterns of ice motion and distribution. The map also shows the boundaries for polar bear subpopulations as defined by the IUCN Polar Bear Specialists Group. Polar bear subpopulations comprising the Polar Basin Divergent Ecoregion (PBDE) include southern Beaufort Sea (SBS), Chukchi Sea (CS), Laptev Sea (LVS), Kara Sea (KS), and the Barents Sea (BS). The Polar Basin Convergent Ecoregion (PBCE) includes East Greenland (EG), Queen Elizabeth (QE), and Northern Beaufort Sea (NBS) populations. The Seasonal Ice Ecoregion (SIE) is comprised of southern Hudson Bay (SHB), western Hudson Bay (WHB), Foxe Basin (FB), Davis Strait (DS), and Baffin Bay (BB) populations. The Archipelago Ecoregion (AE) includes populations from the Gulf of Boothia (GB), M'Clintock Channel (MC), Lancaster Sound (LS), Viscount-Melville Sound (VM), Norwegian Bay (NW), and Kane Basin (KB). 


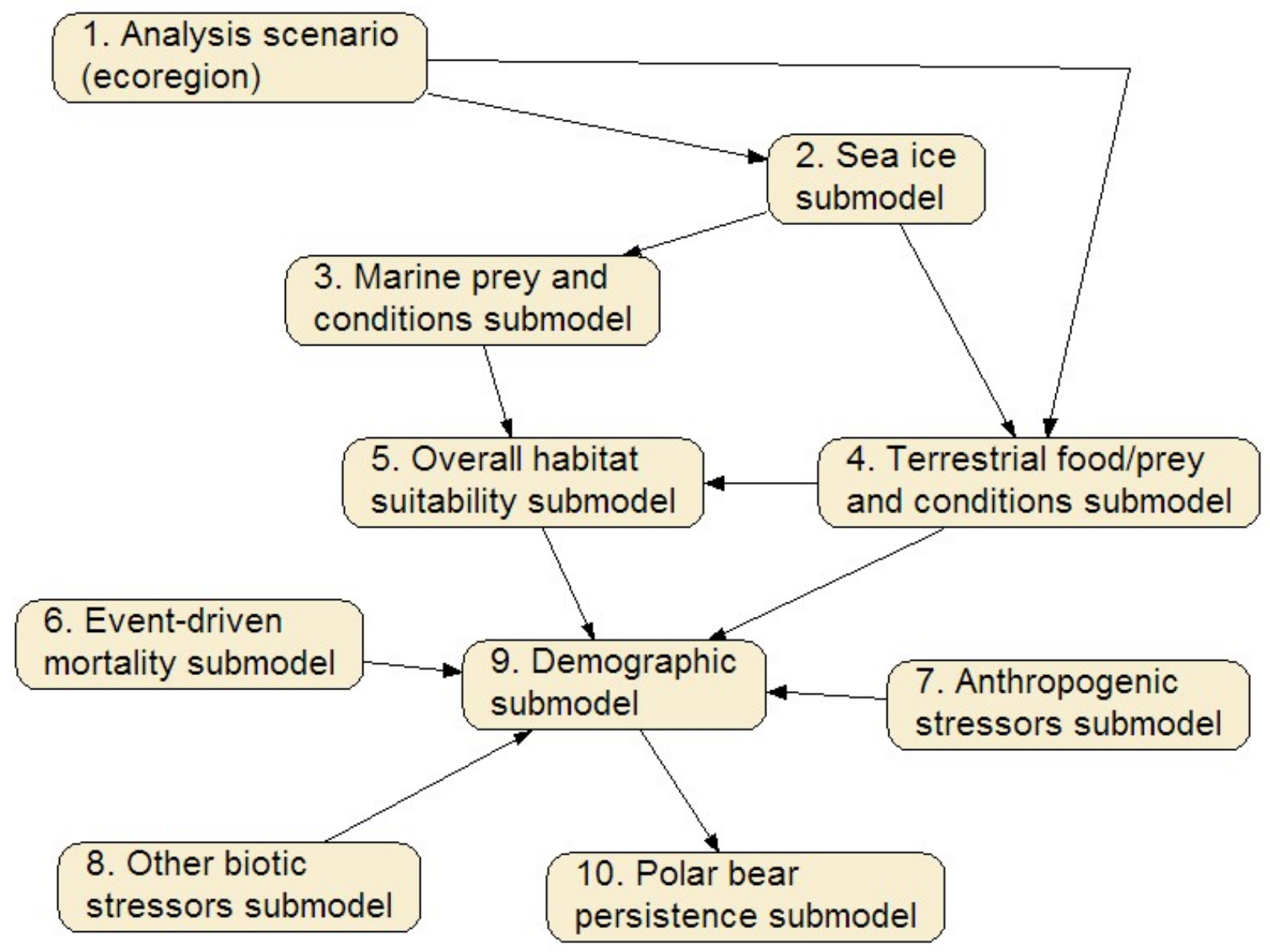

Figure 2. General structure of the second generation model showing the relationships among the 10 submodels. See section "Model Composition" in text for submodel descriptions. 


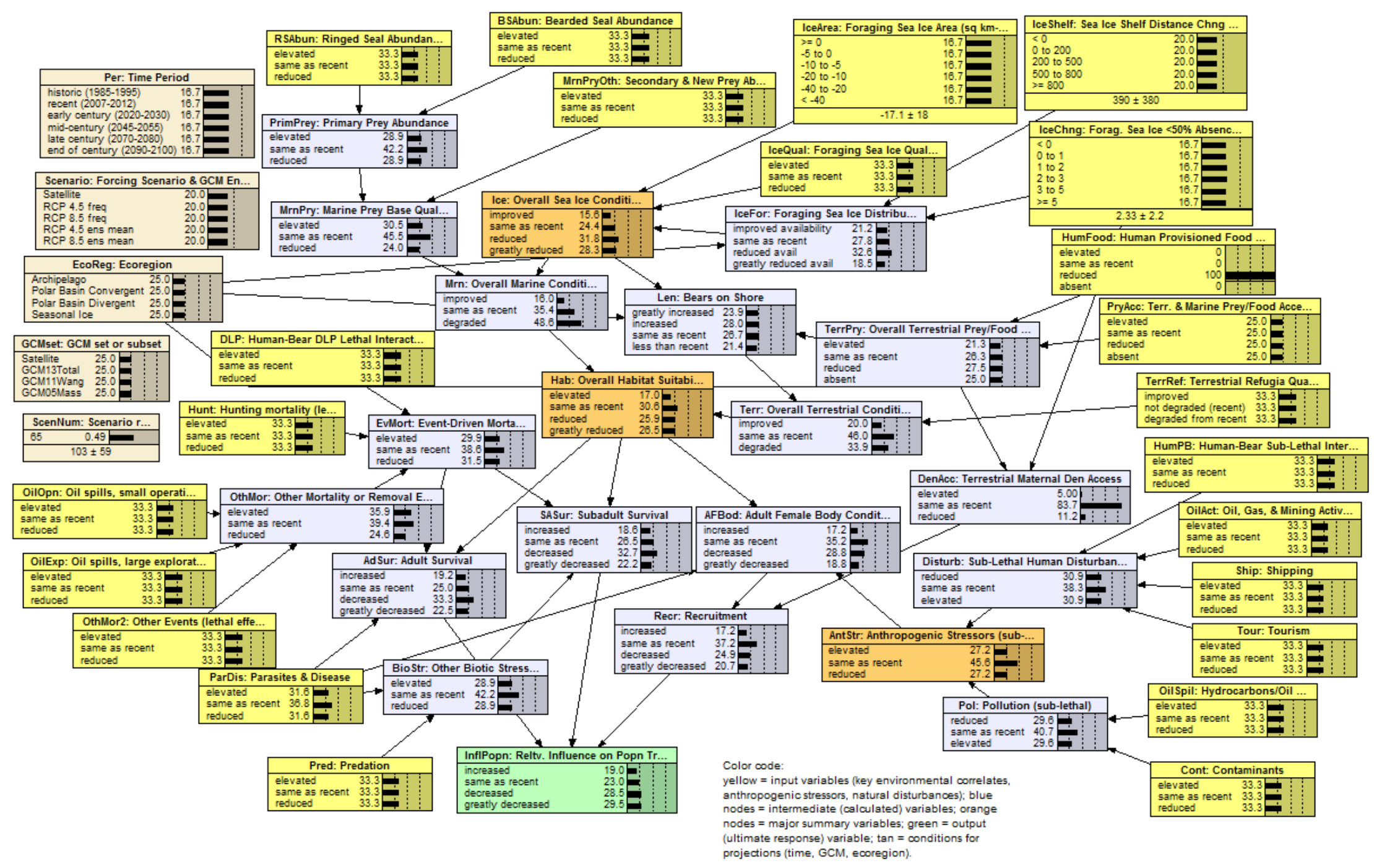

Figure 3. The second generation model used to evaluate the relative influence of stressors on future polar bear population outcomes. 


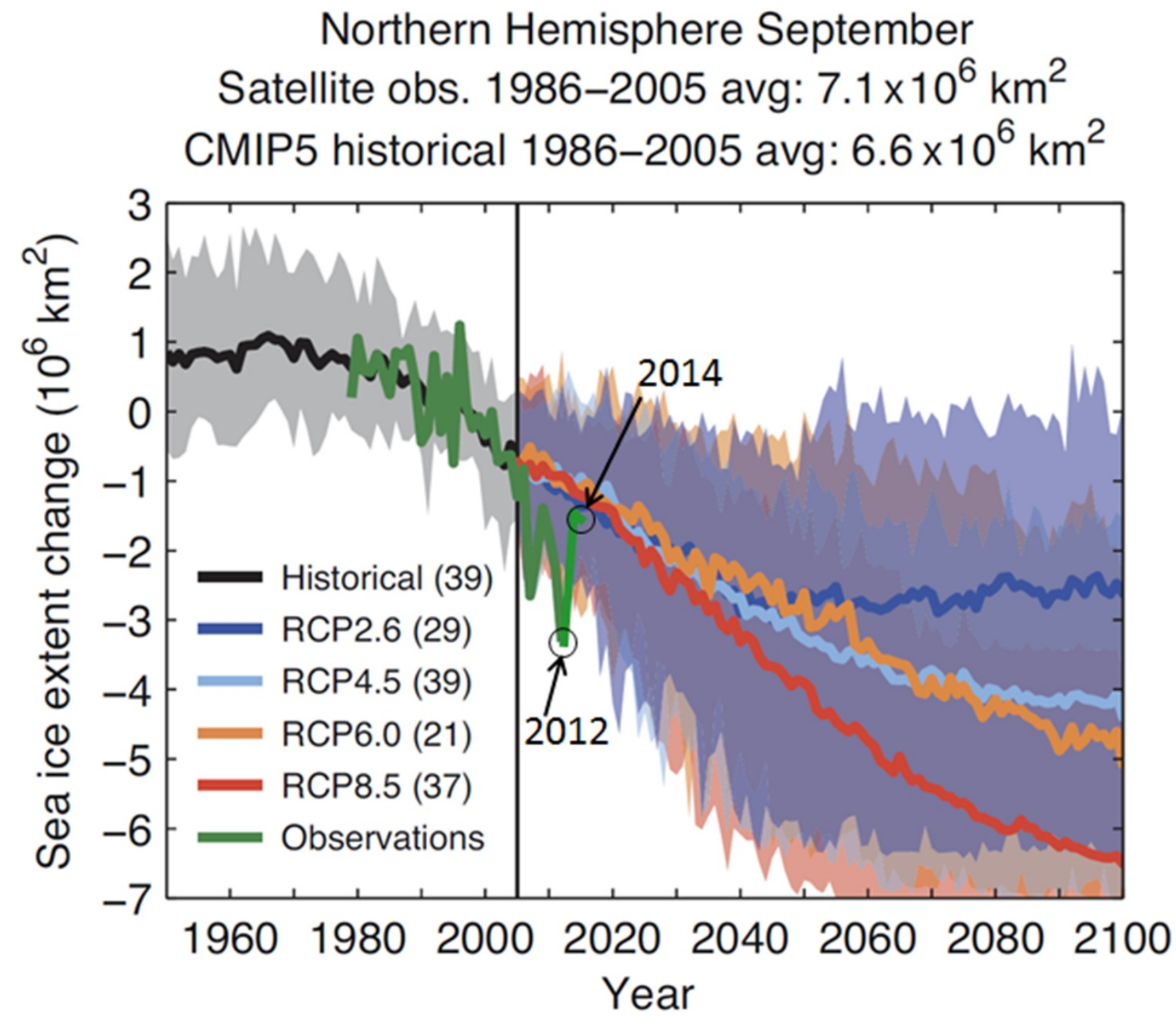

Figure 4. Changes in sea ice extent as simulated by CMIP5 models over the second half of the 20th century and the entire 21st century under RCP2.6, RCP4.5, RCP6.0, and RCP8.5 for the Northern Hemisphere, September (number of models available for each RCP is given in the explanation). The colored lines show the multi-model means, the shading denotes the 5 to 95-percent range of the ensemble, and the vertical line marks the end of CMIP5 historical climate change simulations. Sea ice extent is defined as the total ocean area where sea ice concentration exceeds 15 percent and is calculated on the original model grids, and change is expressed relative to the reference period of 1986-2005. Satellite data of Comiso and Nishio (2008, updated 2012) over 1979-2012, and updates for 2013 and 2014 using data from NSIDC also are plotted (solid green curves). This figure was modified from Collins and others (2013). 


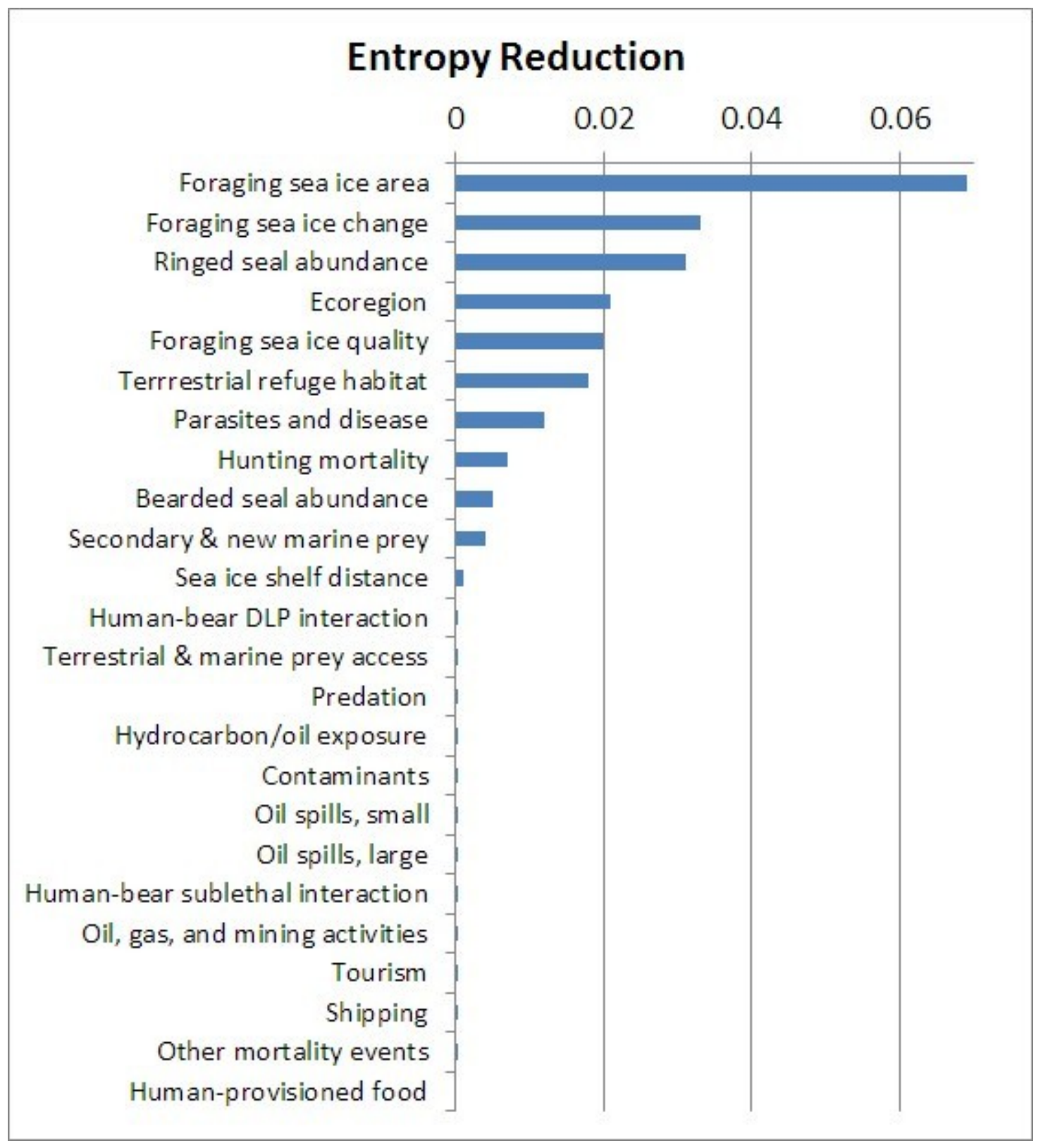

Figure 5. Sensitivity of the final outcome node "relative influence on population trend" to all 24 input (parentless) model nodes. Sensitivity is measured as entropy reduction (also called mutual information), which denotes the degree to which polar bear outcome probabilities are sensitive to (that is, their information content is increased by) a given model input node. The units on the horizontal axis measure the amount of expected reduction in mutual information of the outcome node from a finding for a given input node. 

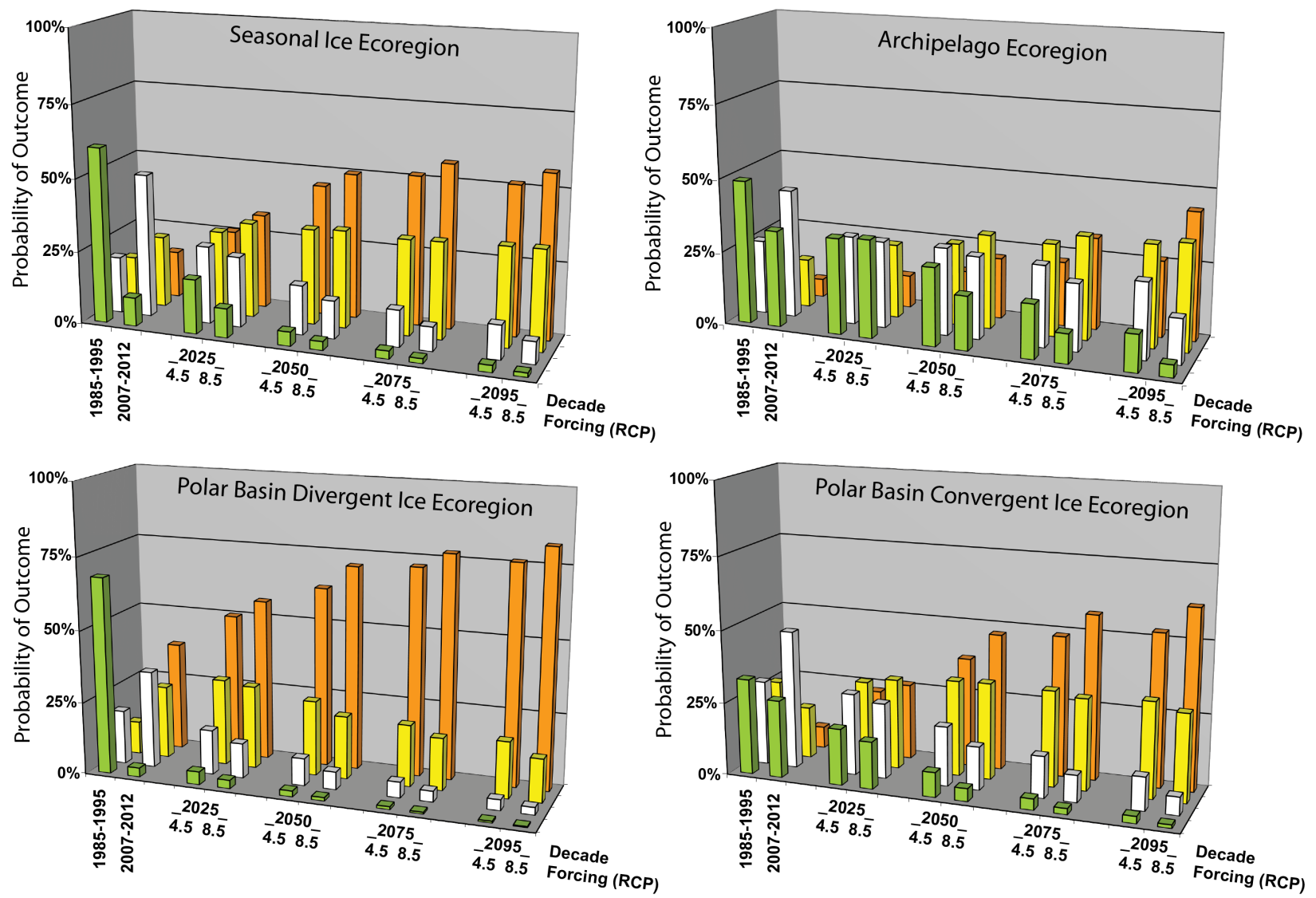

Bayesian Network Model Outcome $\square$ Increased $\square$ Same $\square$ Decreased $\square$ Greatly decreased

Figure 6. Polar bear outcomes from the second generation model. Results are from normative model runs for four ecoregions at one historical, one recent and four future time periods. Historical and recent sea ice conditions were based on observed data. Future sea ice conditions were derived from 13 GCMs using RCP 4.5 and 8.5 . 


\section{Polar Basin Divergent Ice Ecoregion, RCP 4.5}

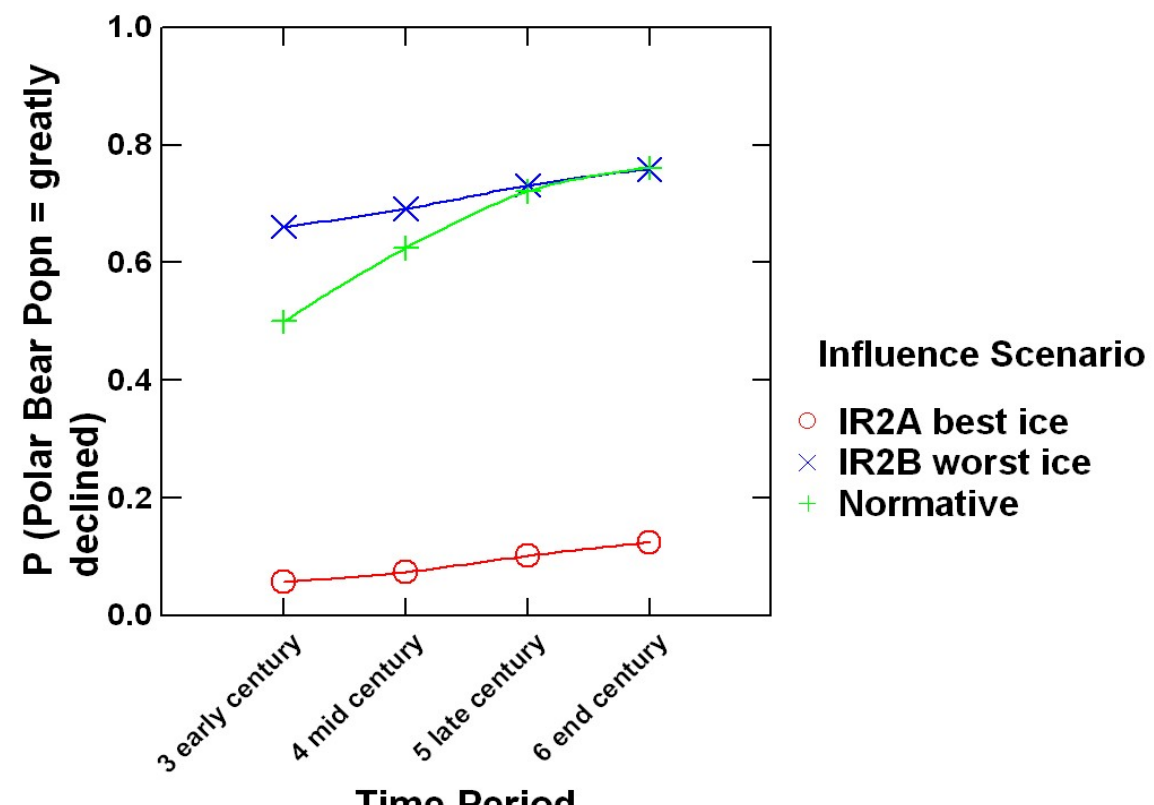

a.

\section{Polar Basin Divergent Ice Ecoregion, RCP 8.5}

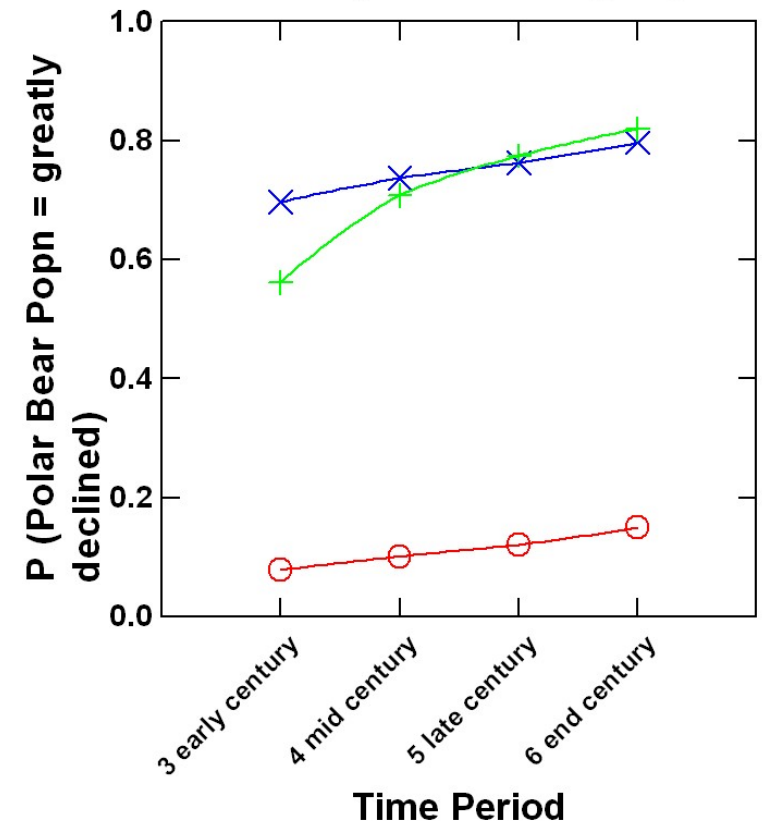

Influence Scenario

IR2A best ice

IR2B worst ice

Normative

b.

Figure 7. Influence of "overall sea ice conditions" $(a, b)$ and "marine prey base" (c, d) on the probability of a "greatly decreased" outcome for polar bears from the Polar Basin Divergent Ecoregion at four future time periods using RCP 4.5 and 8.5. Time periods are 2020-2030 (early century), 2045-2055 (midcentury), 2070-2080 (late century), and 2090-2100 (end of century). 
Polar Basin Divergent Ice Ecoregion, RCP 4.5

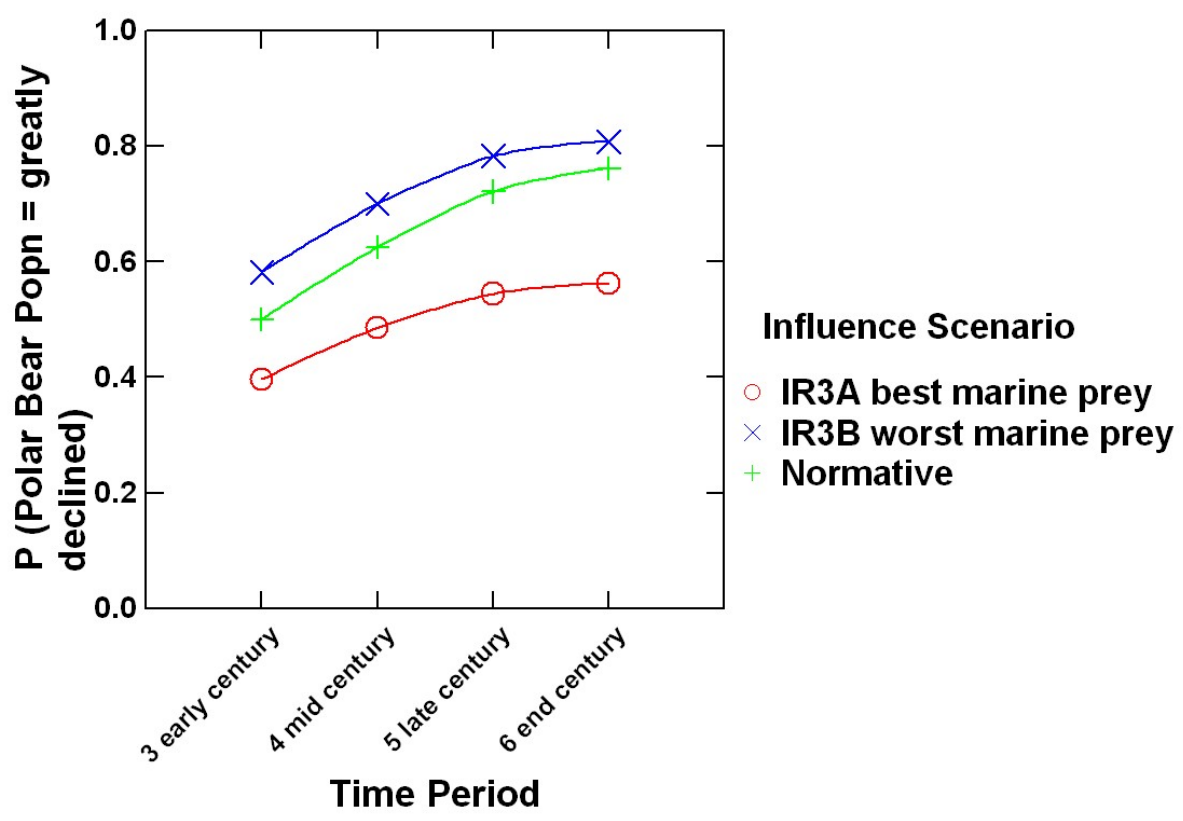

c.

Polar Basin Divergent Ice Ecoregion, RCP 8.5

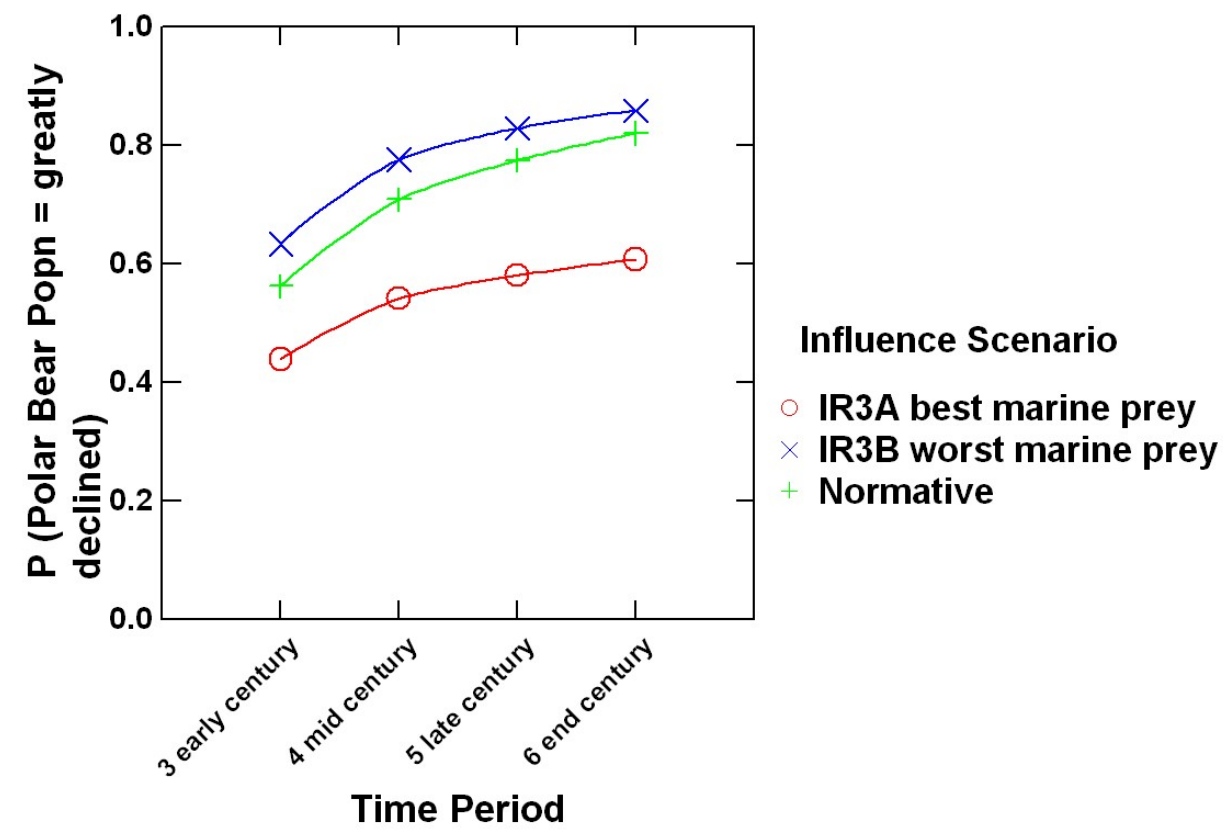

d.

Figure 7. - Continued 


\section{Polar Basin Convergent Ice Ecoregion, RCP 4.5}

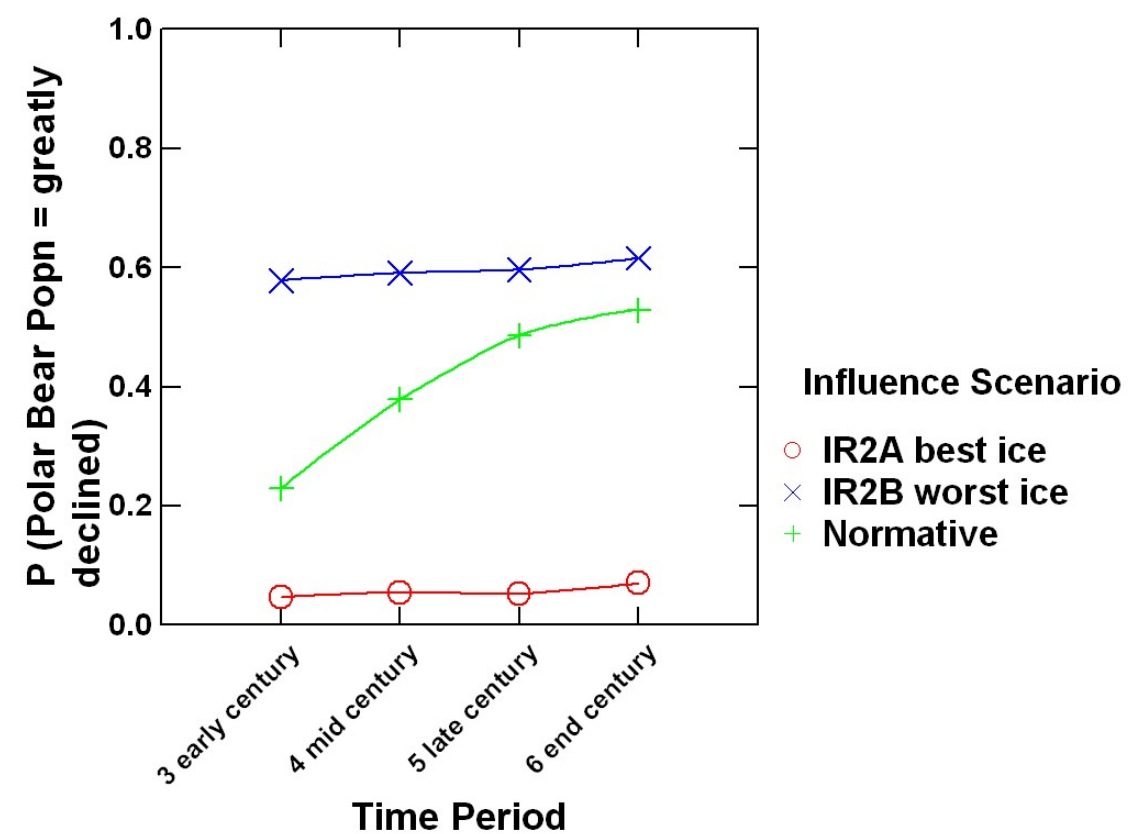

a.

Polar Basin Convergent Ice Ecoregion, RCP 8.5

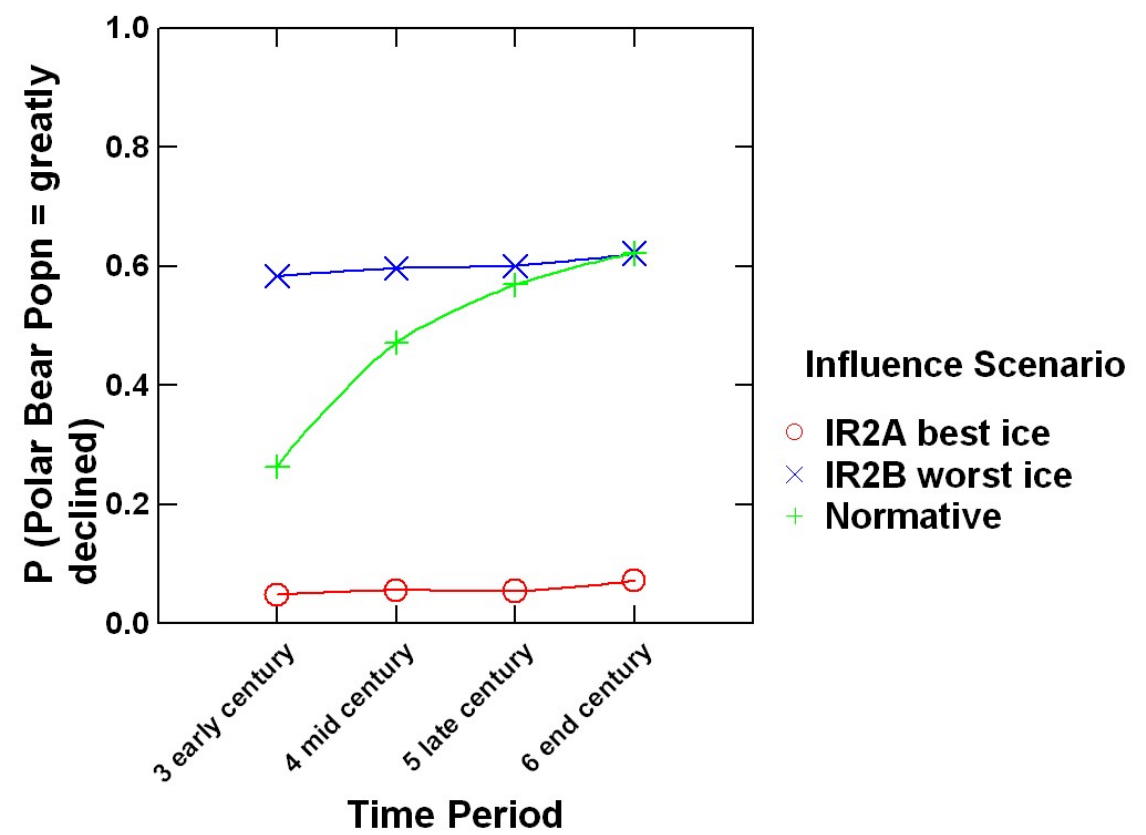

b.

Figure 8. Influence of "overall sea ice conditions" (a, b) and "marine prey base" (c, d) on the probability of a "greatly decreased" outcome for polar bears from the Polar Basin Convergent Ecoregion at four future time periods using RCP 4.5 and 8.5 . 


\section{Polar Basin Convergent Ice Ecoregion, RCP 4.5}

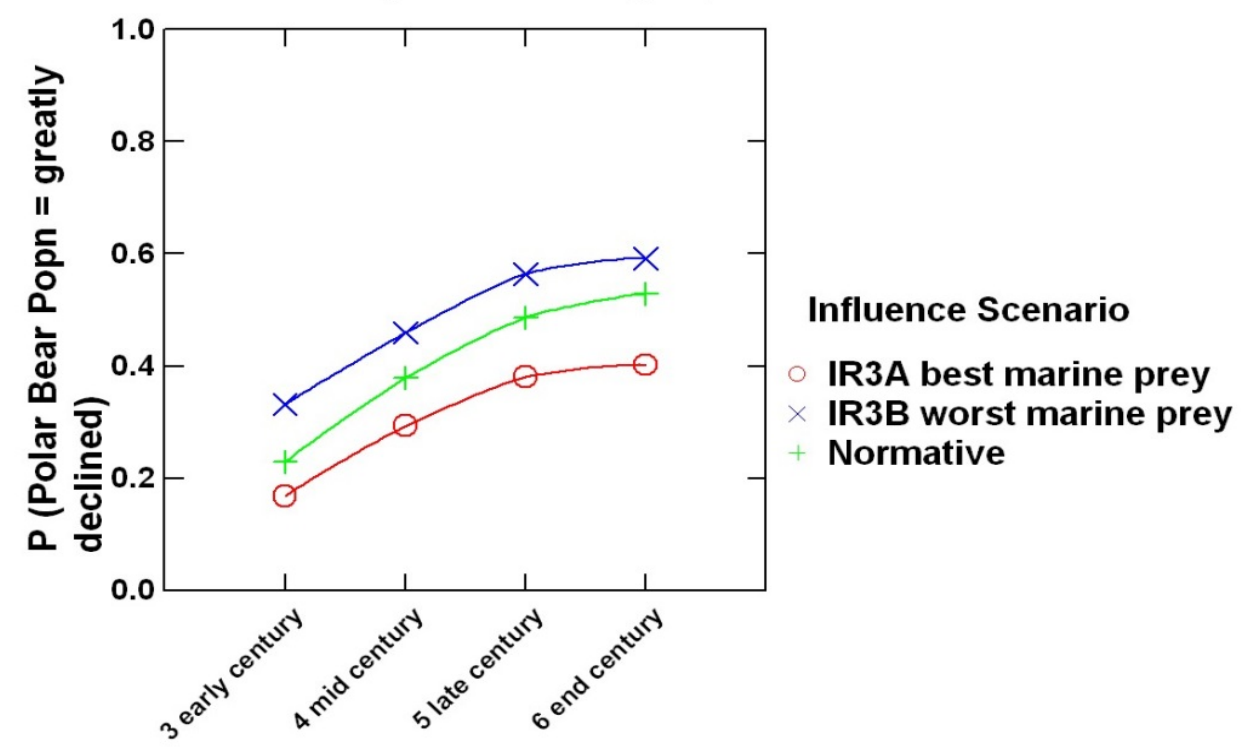

c.

Time Period

Polar Basin Convergent Ice Ecoregion, RCP 8.5

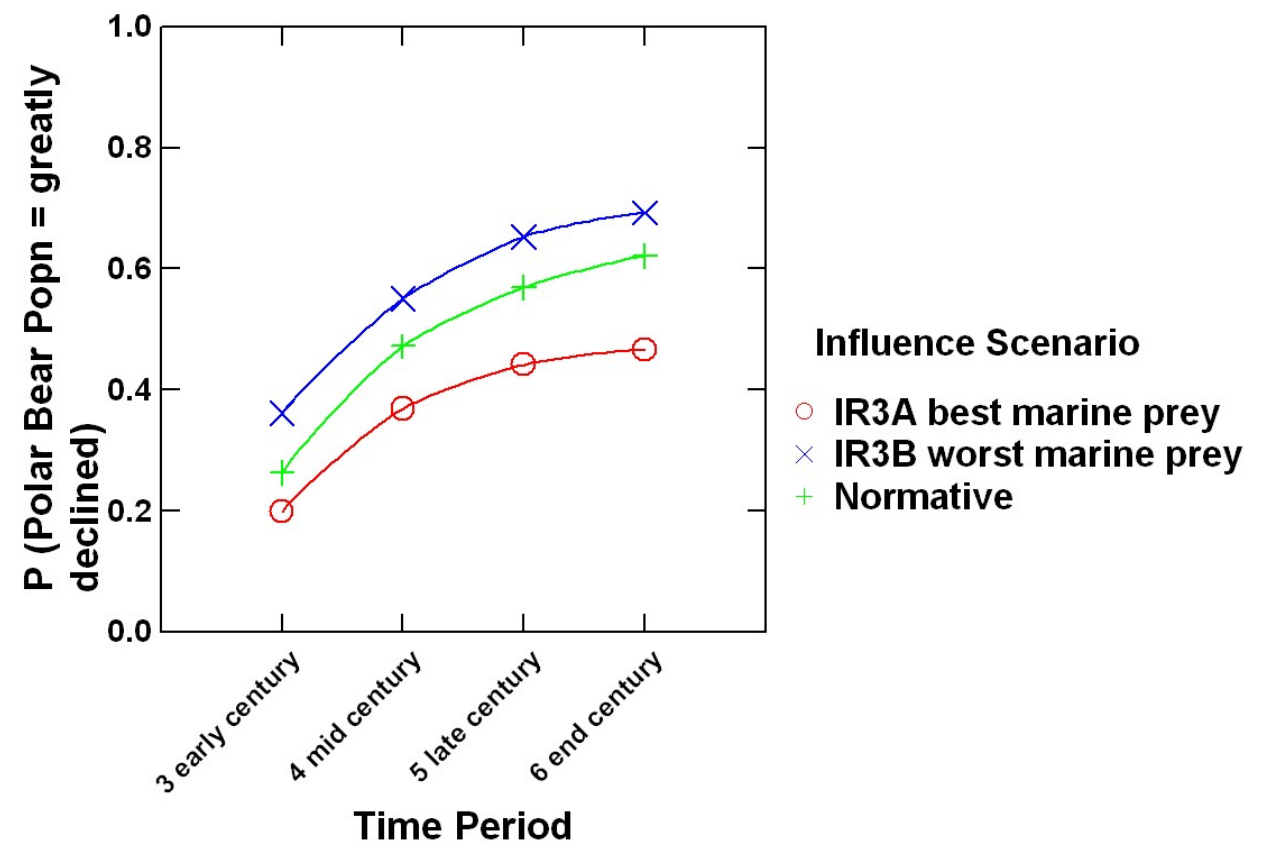

d.

Figure 8.-Continued 


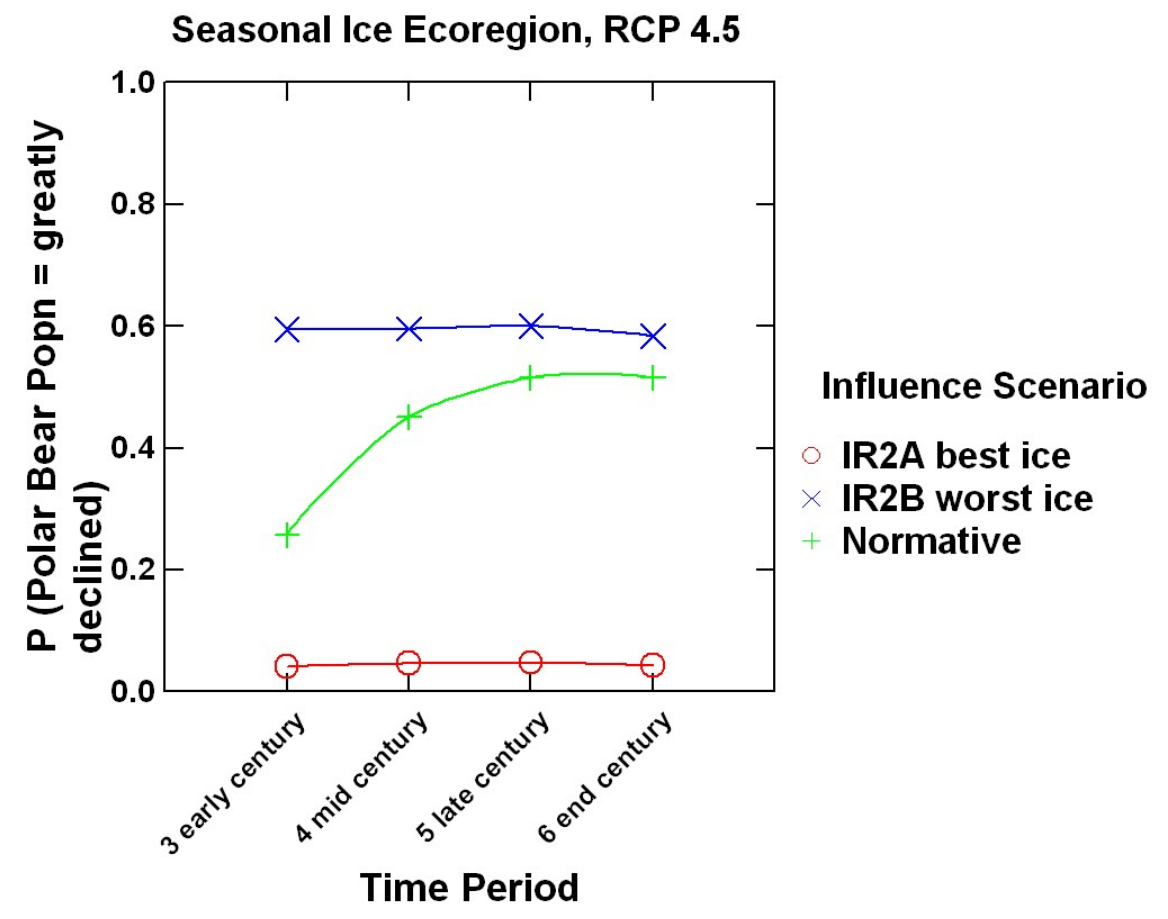

a.

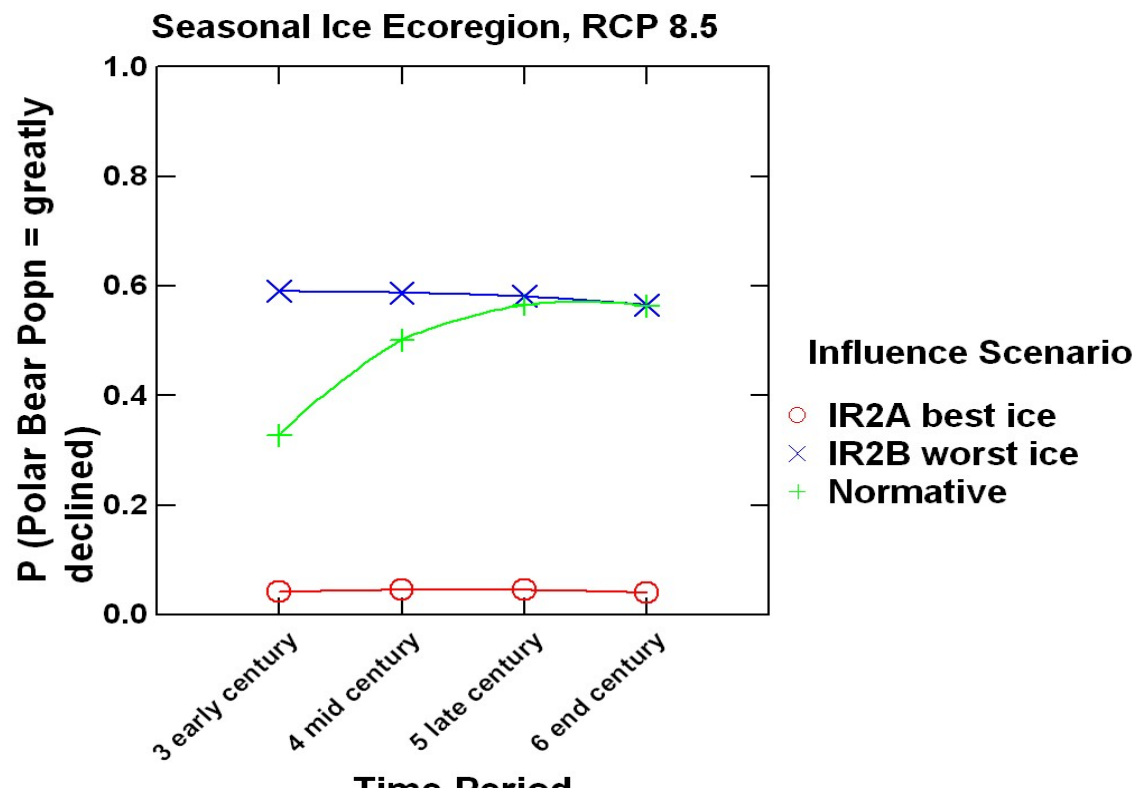

b.

Figure 9. Influence of "overall sea ice conditions" $(a, b)$ and "marine prey base" (c, d) on the probability of a "greatly decreased" outcome for polar bears from the Seasonal Ice Ecoregion at four future time periods using RCP 4.5 and 8.5 . 


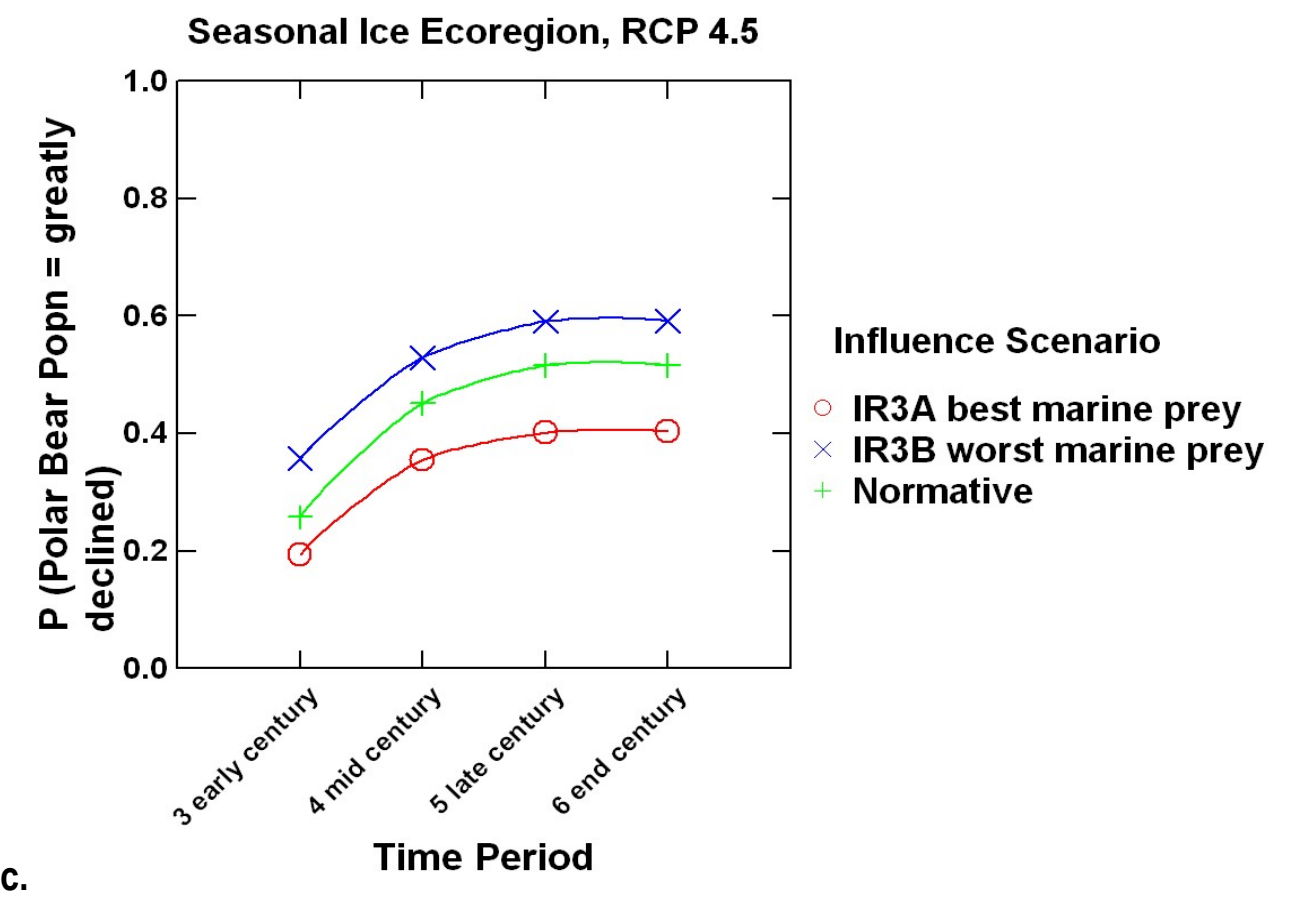

\section{Seasonal Ice Ecoregion, RCP 8.5}

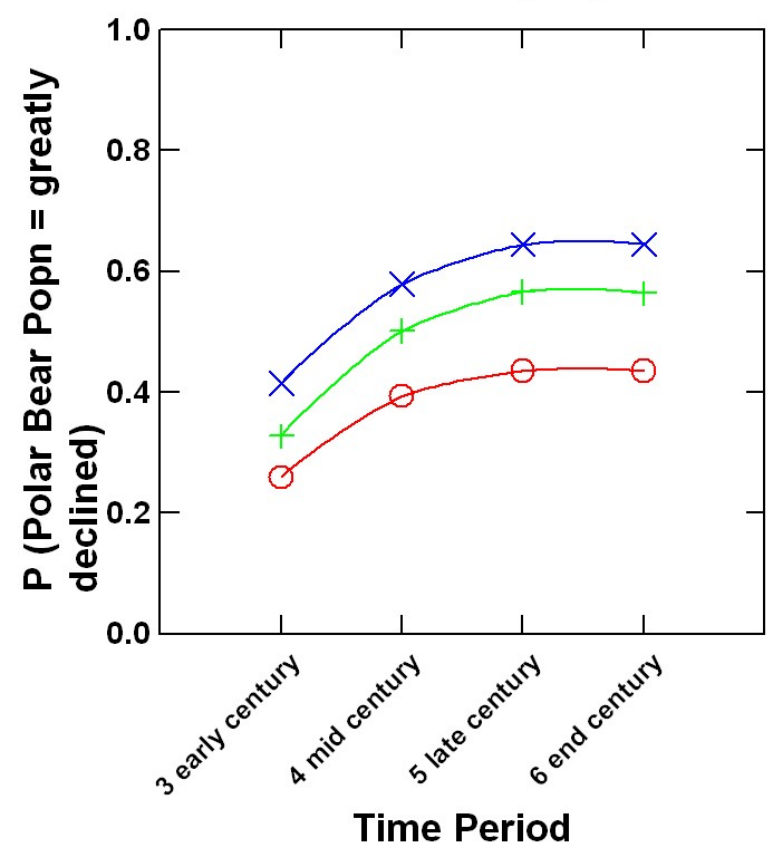

Influence Scenario

IR3A best marine prey

IR3B worst marine prey

Normative

d.

Figure 9. -Continued 


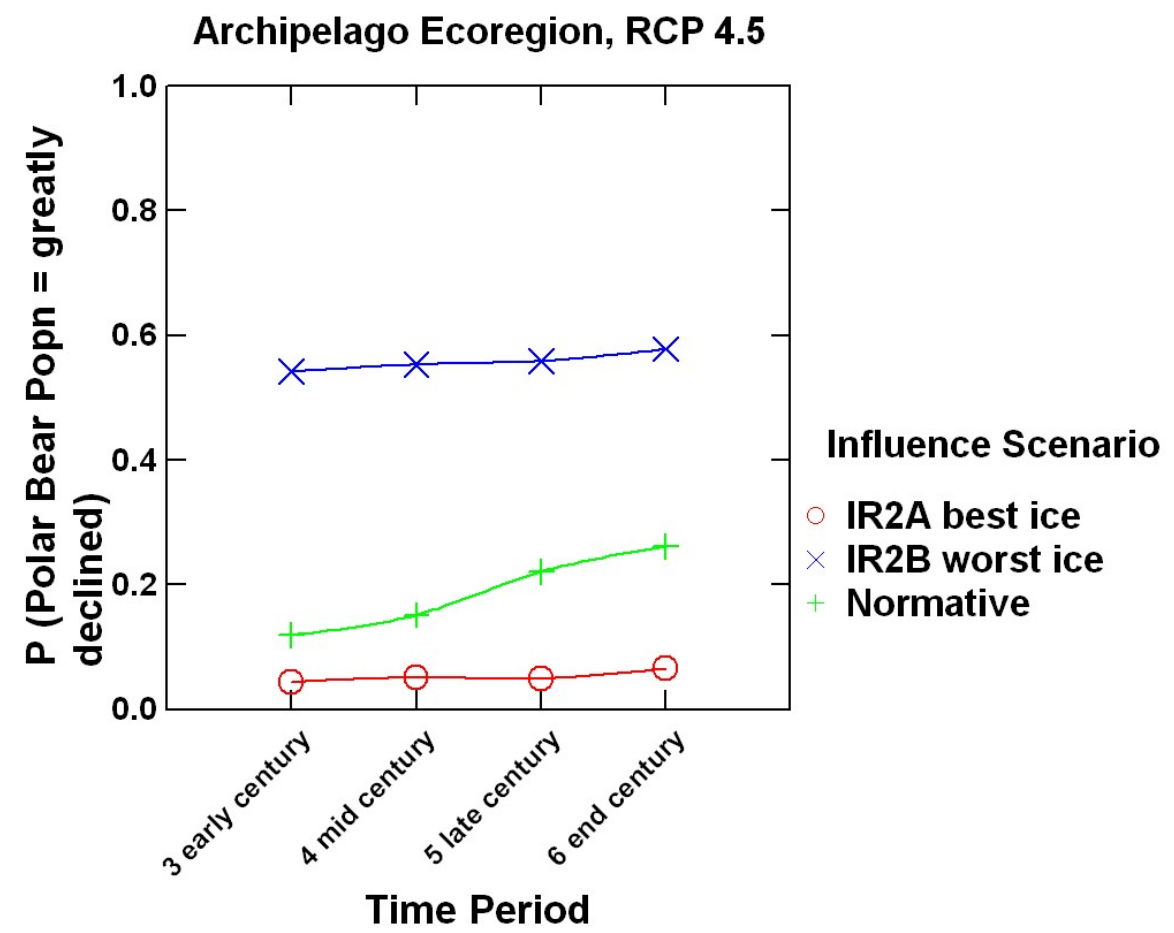

a.

Archipelago Ecoregion, RCP 8.5

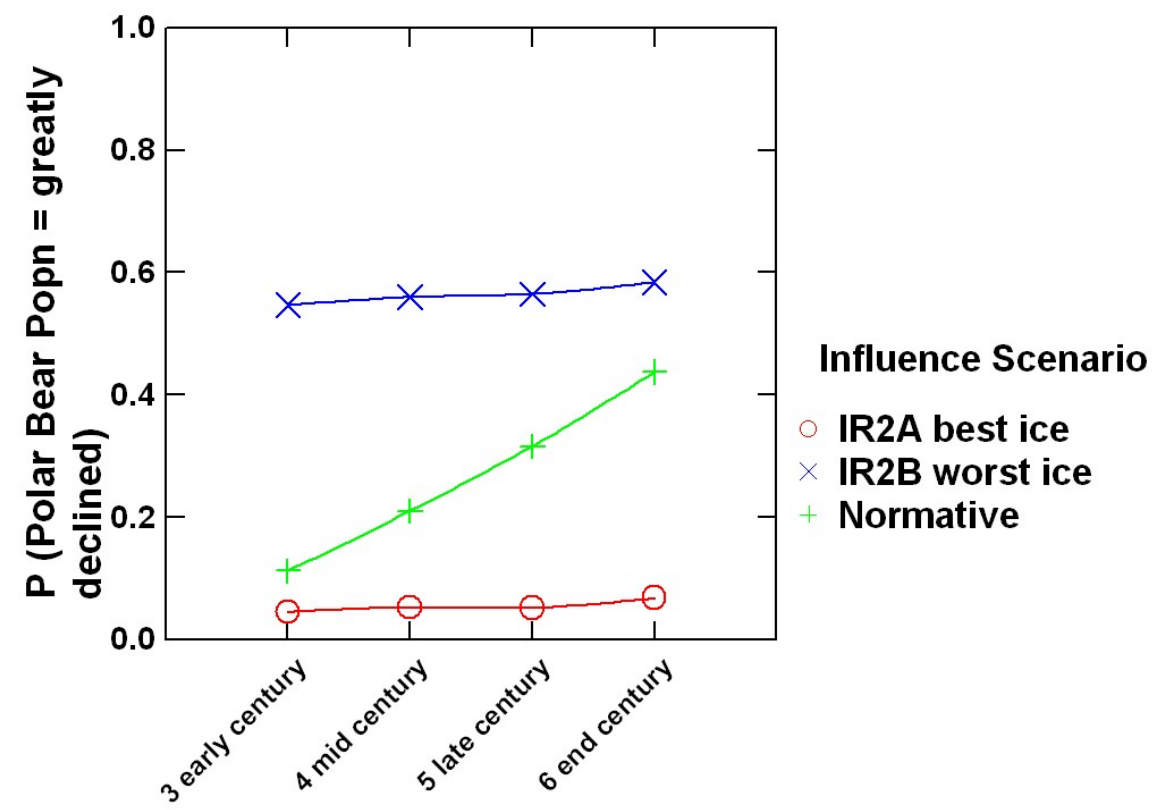

Time Period

b.

Figure 10. Influence of "overall sea ice conditions" $(a, b)$ and "marine prey base" $(c, d)$ on the probability of a "greatly decreased" outcome for polar bears from the Archipelago Ecoregion at four future time periods using RCP 4.5 and 8.5 . 


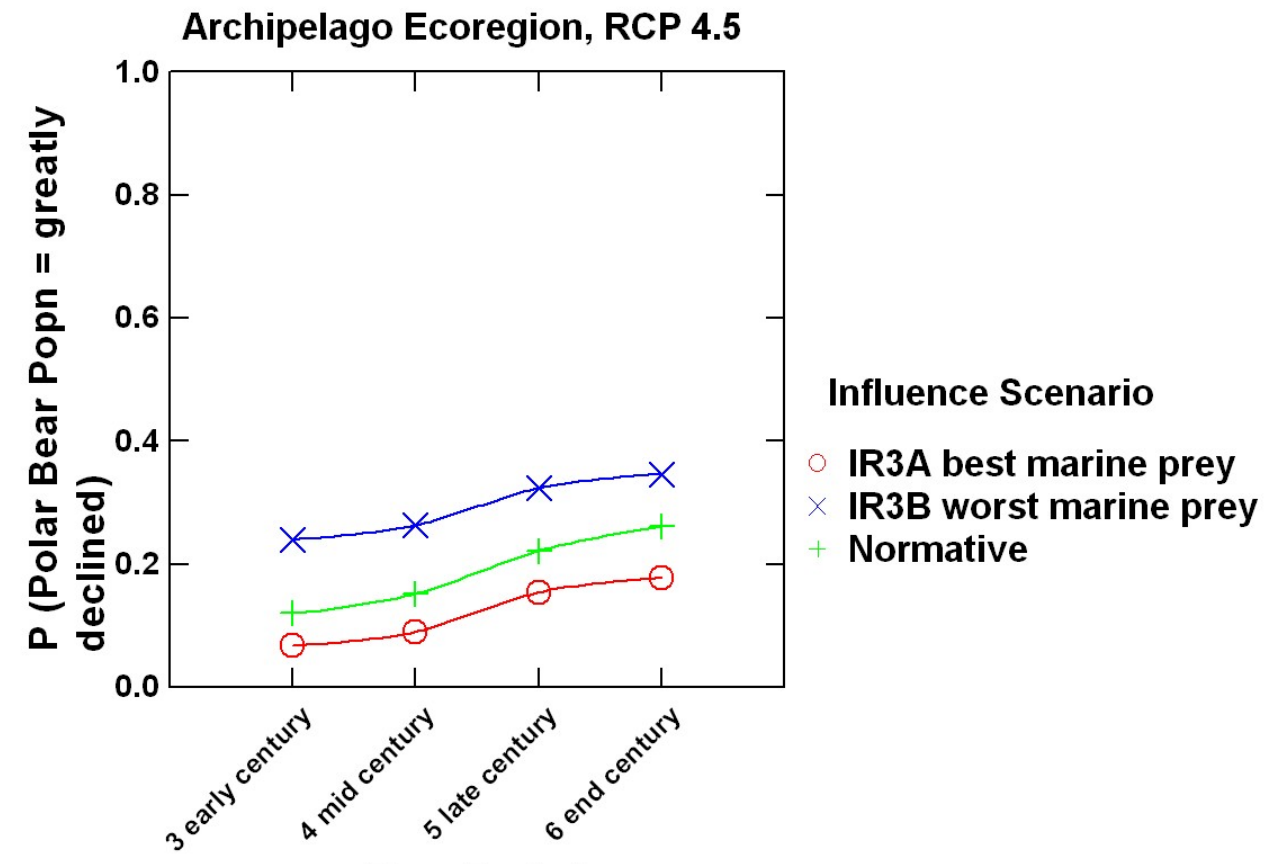

Time Period

c.

Archipelago Ecoregion, RCP 8.5

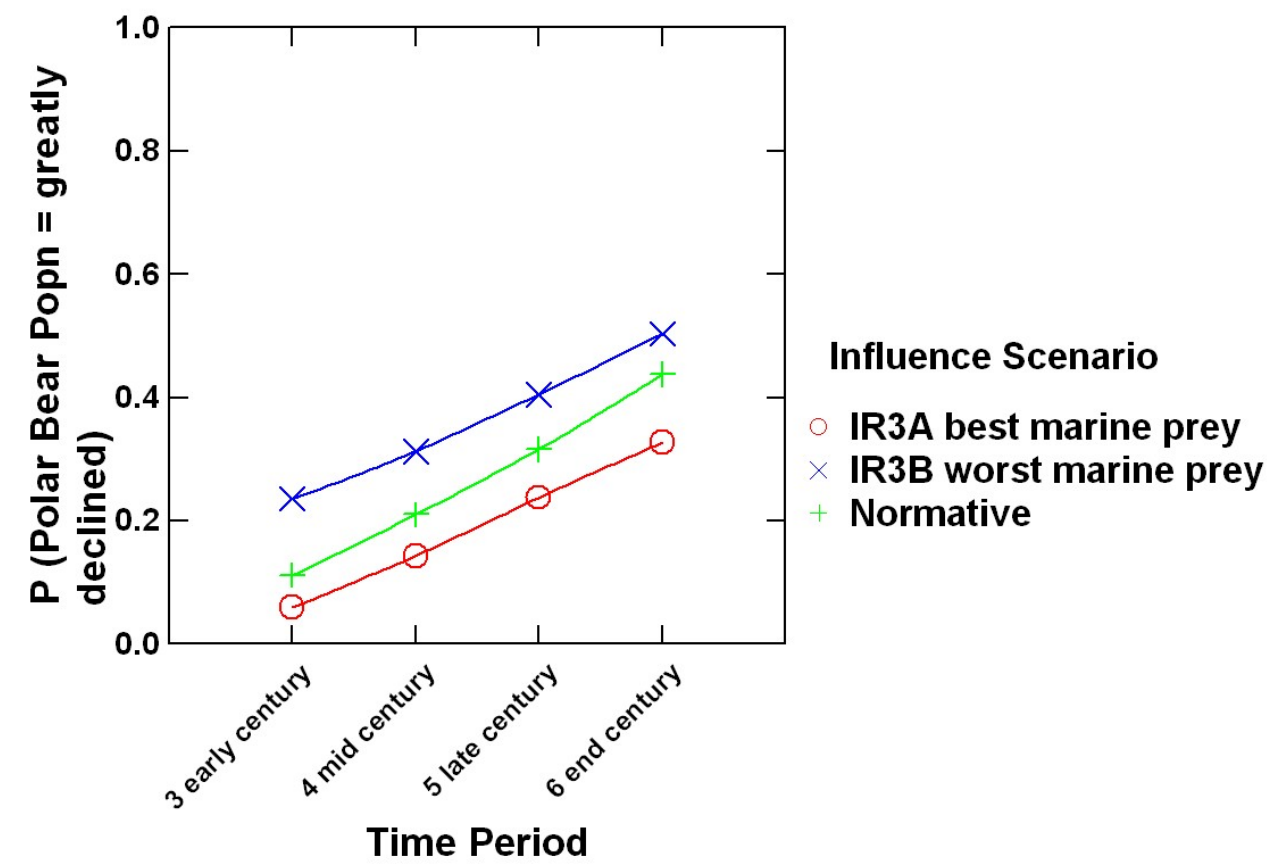

d.

Figure 10.-Continued 


\section{Appendix A. Name, Job Title, Area of Expertise, and Professional Affiliation for Each Subject Matter Expert}

We brought together a team representing expertise in different areas of polar bear life history and representing different geographic regions. Practical limitations also shaped the development of this team. First, because much of the model development occurred in face-to-face meetings, we had to have a team that could meet regularly for extended periods. Secondly, a tractable group size can promote extended discussions of individual estimates and facilitate achieving a consensus (Martin and others, 2012). The team involved in this study, however, was larger than the team used to generate the first generation model and represented a broader range of expertise.

\begin{tabular}{|l|l|l|l|}
\hline \multicolumn{1}{|c|}{ Name } & \multicolumn{1}{|c|}{ Title } & \multicolumn{1}{c|}{ Area of expertise } & \multicolumn{1}{c|}{ Professional affiliation } \\
\hline Bruce Marcot & $\begin{array}{l}\text { Research Wildlife } \\
\text { Biologist }\end{array}$ & $\begin{array}{l}\text { Bayesian network } \\
\text { modeling, biodiversity } \\
\text { assessment }\end{array}$ & U.S. Forest Service \\
\hline David Douglas & $\begin{array}{l}\text { Research Wildlife } \\
\text { Biologist }\end{array}$ & $\begin{array}{l}\text { Movement ecology, sea } \\
\text { ice modeling }\end{array}$ & U.S. Geological Survey \\
\hline Kristin Laidre & $\begin{array}{l}\text { Research Scientist } \\
\text { and Assistant } \\
\text { Professor }\end{array}$ & $\begin{array}{l}\text { Polar bear ecology, } \\
\text { Arctic marine mammal } \\
\text { ecology }\end{array}$ & University of Washington \\
\hline Karyn Rode & $\begin{array}{l}\text { Research Wildlife } \\
\text { Biologist }\end{array}$ & $\begin{array}{l}\text { Polar bear ecology, } \\
\text { physiological ecology }\end{array}$ & U.S. Geological Survey \\
\hline George Durner & Research Zoologist & $\begin{array}{l}\text { Polar bear ecology; } \\
\text { movement ecology }\end{array}$ & U.S. Geological Survey \\
\hline Jeffrey Bromaghin & Research Statistician & $\begin{array}{l}\text { Population ecology, } \\
\text { statistics }\end{array}$ & U.S. Geological Survey \\
\hline Steven Amstrup & Chief Scientist & $\begin{array}{l}\text { Polar bear ecology, } \\
\text { Arctic ecology }\end{array}$ & Polar Bears International \\
\hline Todd Atwood & $\begin{array}{l}\text { Research Wildlife } \\
\text { Biologist }\end{array}$ & $\begin{array}{l}\text { Polar bear ecology; } \\
\text { disease ecology }\end{array}$ & U.S. Geological Survey \\
\hline
\end{tabular}




\section{Appendix B. Additional Information on the Process Used to Develop and Parameterize the Model}

We followed published guidelines for developing BN models (Marcot and others, 2006). We began by establishing a team of subject matter experts (appendix A). We reviewed post-2007 publications from relevant subject areas and then evaluated the structure of the first generation influence diagram. We met as a team to discuss findings, specify the inclusion of new stressors, revise the influence diagram accordingly to reflect the current understanding of relationships among stressors that may affect how they mediate population outcomes.

Next, we specified an adequate set of discrete states for each variable (node). In doing so, all states within each node were intended to be mutually exclusive and collectively exhaustive. Then, we parameterized the influence diagram with conditional probabilities for each node as informed by published literature, empirical and projected data, and expert knowledge. We specified the probability values as follows.

1. First, we met as a team and reviewed the entire model structure, making adjustments in definitions of some nodes and their states and in the connections between nodes, as we collectively viewed the model as a causal web of affector and effector variables.

2. Second, we developed a spreadsheet displaying the framework for each node's conditional probability table. The spreadsheet was sent to each team member who was instructed to provide a first draft of conditional probability values for tables corresponding to variables pertaining to their individual areas of research and expertise. The entire spreadsheet, once compiled and completed from all team members' contributions, was then routed throughout the team in a "round-robin" fashion, to elicit any suggested edits to any of the conditional probability values. Several round-robin team reviews were conducted until the team reached consensus on the probability values, which, being based mostly on expert judgment, were specified to a precision of no more than 5 percent increments. At the same time, the probability tables were entered into the model and the model performance - as a whole or by subsections - was evaluated for consistency with literature and personal research experience. We also used sensitivity analysis on subsections of the model and the entire model to adjust or confirm probability values for realistic behavior (e.g., as conducted by Jay and others, 2011). All sensitivity analyses were conducted by setting the input variables to their default, uniform, prior probability distributions. Sensitivity analysis with categorical variables such as found in our model is expressed as entropy reduction or mutual information, and reflects the degree to which information in an outcome node is increased (entropy or uncertainty is reduced) by an input node.

3. Third, the final set of conditional probability values were entered into the model. Then, after an initial set of runs specifying input conditions by ecoregion, time period, and climate projection pathways, minor adjustments were made to a few probability values to eliminate any anomalous behaviors, such as multi-modal or non-monotonic posterior probability distributions and responses, where clearly uni-modal distributions and monotonic responses would be logical outcomes. Such anomalous behaviors were few and minor, not affecting final outcomes qualitatively. These few instances seemed to have occurred in the model because of differences in the number of states among linked, intermediate nodes. 
Following published model-development protocols, we also invited and incorporated, external peer reviews (e.g., members of the U.S. Polar Bear Recovery Team, Science and Traditional Ecological Knowledge Working Group) at various stages of model development.

Calibration of the model consisted of specifying the model structure and probability values to match the team's collective knowledge and judgment. Validation consisted of adjusting the model based on review comments, and conducting "hindcast" model runs for historical and recent time periods for which sea ice and polar bear conditions have been mostly known or suspected. We then compared modes of model results to those known, earlier conditions, ensuring that the model performed correctly. Because our model is projecting future conditions, "hindcast" validation is the only option available. 


\section{Appendix C. Description (Including Key Assumptions) of All Nodes in the Second Generation Model}

Nodes are listed here by categories of input nodes, intermediate nodes, outcome node, and scenario nodes. Under each node name, the number of the submodel to which it belongs is shown in square brackets. (Submodels are listed in a footnote below this table and described in section, "Model Composition" in the text.)

\begin{tabular}{|c|c|c|c|}
\hline $\begin{array}{l}\text { Node } \\
\text { Name }\end{array}$ & Node Title & Node Description & States \\
\hline \multicolumn{4}{|l|}{ Input Nodes } \\
\hline $\begin{array}{l}\text { RSAbun } \\
{[3]}\end{array}$ & $\begin{array}{l}\text { Ringed Seal } \\
\text { Abundance }\end{array}$ & $\begin{array}{l}\text { This node expresses the observed and expected relationship } \\
\text { between sea ice coverage and phenology and seal } \\
\text { abundance. For example, evidence suggests that earlier } \\
\text { spring break-up of sea ice in western Hudson Bay was } \\
\text { related to declining pup survival (Ferguson and others, } \\
\text { 2005). Declining sea ice likely will directly reduce the } \\
\text { availability of birthing and haul-out habitat for seals. } \\
\text { Earlier break-up also may adversely impact pup survival by } \\
\text { interrupting the lactation period. Ringed seals have the } \\
\text { longest lactation period of the Phocidae and need stable ice } \\
\text { until neonates are weaned (Lydersen and Kovacs, 1999). } \\
\text { In some areas, declines in sea ice may improve biological } \\
\text { productivity, which may benefit seals in the near-term. } \\
\text { However, increased primary productivity will be greatest } \\
\text { during summer (after break-up) and benefits may be } \\
\text { mitigated by reduced biomass in coastal/shelf area due to } \\
\text { increased river runoff and associated changes in turbidity } \\
\text { and salinity (e.g., Bluhm and Gradinger, 2008). }\end{array}$ & $\begin{array}{l}\text { Elevated } \\
\text { Same as } \\
\text { Recent } \\
\text { Reduced }\end{array}$ \\
\hline $\begin{array}{l}\text { BSAbun } \\
\text { [3] }\end{array}$ & $\begin{array}{l}\text { Bearded Seal } \\
\text { Abundance }\end{array}$ & $\begin{array}{l}\text { This node expresses changes in bearded seal abundance } \\
\text { that are likely to occur as sea ice cover declines and its } \\
\text { character changes. Bearded seals are believed to have a } \\
\text { patchy distribution throughout their range. Because of this, } \\
\text { encounter rates with polar bears likely are lower than for } \\
\text { ringed seals. However, bearded seals are considerably } \\
\text { larger than ringed seals, so biomass consumed by polar } \\
\text { bears is likely similar (e.g., Pilfold and others, } 2012 \text {. } \\
\text { Bearded seals prefer drifting pack ice over shallow } \\
\text { water/coastal areas. Because of this, they may be more } \\
\text { vulnerable to reductions in biomass in coastal areas due to } \\
\text { increased river runoff and associated changes in turbidity } \\
\text { and salinity (e.g., Bluhm and Gradinger, 2008). }\end{array}$ & $\begin{array}{l}\text { Elevated } \\
\text { Same as } \\
\text { Recent } \\
\text { Reduced }\end{array}$ \\
\hline $\begin{array}{l}\text { MrnPryOth } \\
\text { [3] }\end{array}$ & $\begin{array}{l}\text { Secondary and } \\
\text { New Prey } \\
\text { Abundance }\end{array}$ & $\begin{array}{l}\text { This node expresses changes in the abundance of secondary } \\
\text { prey that are likely to occur as sea ice cover declines and its } \\
\text { physical character changes. Secondary prey can include } \\
\text { beluga whales (Delphinapterus leucas), harp seals, hooded } \\
\text { seals, spotted seals, ribbon seals, and other marine }\end{array}$ & $\begin{array}{l}\text { Elevated } \\
\text { Same as } \\
\text { Recent } \\
\text { Reduced }\end{array}$ \\
\hline
\end{tabular}




\begin{tabular}{|c|c|c|c|}
\hline $\begin{array}{l}\text { Node } \\
\text { Name }\end{array}$ & Node Title & Node Description & States \\
\hline & & $\begin{array}{l}\text { mammals (e.g., Pacific walrus). For example, as pack ice } \\
\text { becomes less available in the Bering Sea, ribbon seal range } \\
\text { likely will expand northward to maintain access to pack ice } \\
\text { during the birthing period (Lowry and Boveng, 2009). } \\
\text { Likewise, spotted seals regularly haul out on shore and are } \\
\text { less reliant on sea ice, and may expand northward as } \\
\text { summer ice cover declines (Kovacs and others, 2011). Last, } \\
\text { ribbon, harp, and hooded seals can spend long periods } \\
\text { pelagically in areas without ice (Kovacs and others, 2011, } \\
\text { making them somewhat resilient to loss of sea ice habitat. } \\
\text { As the ice retreats into the AE, it is reasonable to expect } \\
\text { that prey species may penetrate deeper into that region and } \\
\text { provide at least a transient improvement in alternate prey. It } \\
\text { is unclear, however, that such changes could persist as } \\
\text { bears are forced onto smaller and smaller areas of ice. }\end{array}$ & \\
\hline $\begin{array}{l}\text { IceArea } \\
{[2]}\end{array}$ & $\begin{array}{l}\text { Foraging Sea } \\
\text { Ice Area }\end{array}$ & $\begin{array}{l}\text { This node expresses the proportional change in the area of } \\
\text { polar bear habitat over time, and is derived from the } \\
\text { satellite passive microwave record for the observational } \\
\text { period, and from GCM outputs of sea ice for the 1996- } \\
2006 \text { baseline (historical forcing) and future periods } \\
\text { (RCP4.5 and RCP8.5 forcing). Habitat is expressed as the } \\
\text { number of square kilometer months of optimal habitat } \\
\text { (Durner and others, 2009) in the two polar basin } \\
\text { ecoregions, and as square kilometer months of ice over } \\
\text { continental shelf in the other ecoregions (AE and SIE). } \\
\text { Because the AE and SIE are almost entirely shallow water } \\
\text { areas, the 'optimal' habitat in those areas equates to } \\
\text { essentially the ice extent months for each region. We } \\
\text { further expressed this as the average percent change in } \\
\text { quantity of these ice habitats, from the 1996-2006 baseline } \\
\text { period to the projected future period of interest. } \\
\text { Interpreting the percent difference must take into account } \\
\text { that a given percent change may not be directly comparable } \\
\text { between ecoregions. The absolute change in the AE, for } \\
\text { example may be very small, but because it is measured } \\
\text { from essentially 0, it may seem like a great percentage. }\end{array}$ & $\begin{array}{l}>=0 \\
-5 \text { to } 0 \\
-10 \text { to }-5 \\
-20 \text { to }-10 \\
-40 \text { to }-20 \\
<-40 \\
\text { (proportional } \\
\text { change) }\end{array}$ \\
\hline $\begin{array}{l}\text { IceQual } \\
\text { [2] }\end{array}$ & $\begin{array}{l}\text { Foraging Sea } \\
\text { Ice Quality }\end{array}$ & $\begin{array}{l}\text { This node expresses a subjective assessment of the quality } \\
\text { of sea ice for foraging by polar bears. Recent observations } \\
\text { of the changes in sea ice characteristics in several Arctic } \\
\text { seas and regions (e.g., southern Beaufort and Chukchi Seas } \\
\text { [Mahoney and others, 2012], Hudson Bay [Gagnon and } \\
\text { Gough, 2005; Sahanatien and Derocher, 2012]) suggest that } \\
\text { the later freeze up, warmer winters, and earlier ice retreat in } \\
\text { summer have resulted in thinner ice that more easily } \\
\text { deforms and more frequently rafts over itself. These } \\
\text { changes have reduced the quality of ice as a denning } \\
\text { substrate, and may have reduced its quality as a foraging }\end{array}$ & $\begin{array}{l}\text { Elevated } \\
\text { Same as } \\
\text { Recent } \\
\text { Reduced }\end{array}$ \\
\hline
\end{tabular}




\begin{tabular}{|c|c|c|c|}
\hline $\begin{array}{l}\text { Node } \\
\text { Name }\end{array}$ & Node Title & Node Description & States \\
\hline & & $\begin{array}{l}\text { substrate because the extensive ice deformation can result } \\
\text { in ice covered refugia for ringed seals, which are less likely } \\
\text { for polar bears to get into. } \\
\text { However, very thick and dense ice in the AE and the } \\
\text { northern part of the PBCE may have limited access to prey, } \\
\text { and foraging ice quality might first improve with global } \\
\text { warming and then decline. }\end{array}$ & \\
\hline $\begin{array}{l}\text { IceShelf } \\
\text { [2] }\end{array}$ & $\begin{array}{l}\text { Sea Ice Shelf } \\
\text { Distance } \\
\text { Change }\end{array}$ & $\begin{array}{l}\text { This metric expresses the distance (in kilometers) that the } \\
\text { summer ice retreats from traditional autumn/winter } \\
\text { foraging areas, which are over the continental shelves and } \\
\text { other shallow water areas within the polar basin. It was } \\
\text { calculated by extracting the largest contiguous expanse of } \\
\text { pack ice whose pixels have }>50 \text { percent concentration and } \\
\text { calculating the mean of the linear distances between all } \\
\text { pixels in the shelf waters to the nearest pack ice during the } \\
\text { month of minimum non-zero ice extent. It was expressed as } \\
\text { the difference between this mean distance averaged for the } \\
\text { period } 1996-2006 \text { and the average distance as calculated } \\
\text { for other time periods of interest. This metric was derived } \\
\text { from the satellite passive microwave record for the } \\
\text { observational period, and from GCM outputs of sea ice for } \\
\text { the } 1996 \text {-2006 baseline (historical forcing) and future } \\
\text { periods (RCP4.5 and RCP8.5 forcing). } \\
\text { The metric was derived only for the polar basin regions } \\
\text { (PBDE and PBCE) because polar bears in the AE and SIE } \\
\text { typically go to shore when the summer ice retreats, as } \\
\text { opposed to retreating with the ice as bears in the polar basin } \\
\text { tend to do. The distance that summer ice retreats away } \\
\text { from shelf water areas, where polar bears traditionally } \\
\text { forage in autumn/winter, lends information to the question } \\
\text { of can or will bears make round-trips between traditional } \\
\text { denning/foraging areas and remnant summer pack ice. } \\
\text { States are discretized ranges of the continuous variable, } \\
\text { measured as kilometers. }\end{array}$ & $\begin{array}{l}<0 \\
0 \text { to } 200 \\
200 \text { to } 500 \\
500 \text { to } 800 \\
>=800 \\
\text { (kilometers) }\end{array}$ \\
\hline $\begin{array}{l}\text { IceChng } \\
\text { [2] }\end{array}$ & $\begin{array}{l}\text { Foraging Sea } \\
\text { Ice }<50 \% \\
\text { Absence }\end{array}$ & $\begin{array}{l}\text { This node expresses the length in months of ice absence } \\
\text { from the continental shelf regions historically preferred by } \\
\text { polar bears. The metric was the number of months during } \\
\text { which the continental shelf was ice free, where ice free was } \\
\text { defined as fewer than } 50 \text { percent of the pixels over the shelf } \\
\text { having less than } 50 \text { percent ice cover. The metric expresses } \\
\text { the difference in months between the forecasted number of } \\
\text { ice free months for future time periods and the number of } \\
\text { ice free months for the baseline, which was defined as the } \\
\text { GCM model outputs for the period } 1996-2006 \text {. This } \\
\text { metric was derived from the satellite passive microwave } \\
\text { record for the observational period, and from GCM outputs } \\
\text { of sea ice for the 1996-2006 baseline (historical forcing) }\end{array}$ & $\begin{array}{l}<0 \\
0 \text { to } 1 \\
1 \text { to } 2 \\
2 \text { to } 3 \\
3 \text { to } 5 \\
>=5 \\
\text { (months) }\end{array}$ \\
\hline
\end{tabular}




\begin{tabular}{|c|c|c|c|}
\hline $\begin{array}{l}\text { Node } \\
\text { Name }\end{array}$ & Node Title & Node Description & States \\
\hline & & $\begin{array}{l}\text { and future periods (RCP } 4.5 \text { and RCP } 8.5 \text { forcing). } \\
\text { Polar bears in some regions already experience ice free } \\
\text { periods. The impact of the length of the ice free period is } \\
\text { dependent mainly on the productivity of the environment } \\
\text { and the availability of refugia habitat (such as terrestrial } \\
\text { habitat) and alternative food resources, and has a different } \\
\text { impact in the Beaufort Sea, for example, than it does in the } \\
\text { seasonal ice region, which is relatively productive. The } \\
\text { length in months of ice absence expressed in the } \\
\text { conditional probability table must be interpreted with } \\
\text { regard to the fact that in large parts of these areas even at a } \\
\text { mean } 1-3 \text { months of increased ice absence, actual absence } \\
\text { in some parts of these regions would still be } 0 \text {. An absence } \\
\text { difference of }>3 \text { months means a mean absence of } 4 \text { or } 5+ \\
\text { months in the PBDE, and } 7,8 \text {, or } 9+\text { months in the SIE, but } \\
\text { only } 3+\text { months in portions of the AE or PBCE. }\end{array}$ & \\
\hline $\begin{array}{l}\text { HumFood } \\
{[4]}\end{array}$ & $\begin{array}{l}\text { Human } \\
\text { Provisioned } \\
\text { Food } \\
\text { Abundance }\end{array}$ & $\begin{array}{l}\text { This node expresses the availability of human-provisioned } \\
\text { food and can include remains from harvest of whales, other } \\
\text { marine mammals, and other game. This node also can refer } \\
\text { to other organic refuse or food sources for polar bears. The } \\
\text { availability of human-provisioned food is most pertinent } \\
\text { during autumn months, as that is likely when the biggest } \\
\text { nutritional contribution is realized (Herreman and Peacock, } \\
2013 \text { ). However, there is some evidence that polar bears } \\
\text { will visit bone piles throughout the winter. That said, it is } \\
\text { not expected that they get a substantial nutritional input } \\
\text { from those winter visitations. This node is mostly relevant } \\
\text { to the PBDE and the SIE. }\end{array}$ & $\begin{array}{l}\text { Elevated } \\
\text { Same as } \\
\text { Recent } \\
\text { Reduced } \\
\text { Absent }\end{array}$ \\
\hline $\begin{array}{l}\text { PryAcc } \\
{[4]}\end{array}$ & $\begin{array}{l}\text { Terrestrial and } \\
\text { Marine Prey } \\
\text { and Food } \\
\text { Accessibility }\end{array}$ & $\begin{array}{l}\text { This node expresses the availability of terrestrial prey and } \\
\text { other food resources, including scavenge subsidies (other } \\
\text { than human-provisioned) on land or in proximity to land } \\
\text { (e.g., consolidated glacial ice). Food resources could } \\
\text { include Arctic char (Salvelinus alpinus), bird colonies, } \\
\text { berries, vegetation, seaweed, caribou, geese, ice seals on } \\
\text { glacial ice, beach cast of marine prey (e.g., seal carcasses } \\
\text { that wash ashore). There is evidence in the literature that } \\
\text { polar bears have historically exploited terrestrial-based } \\
\text { foods. There also is some evidence that use of terrestrial- } \\
\text { based food is increasing in some ecoregions (e.g., Born and } \\
\text { others, 2011; Iverson and others, 2014). In general, we } \\
\text { believe that the availability of terrestrial food may facilitate } \\
\text { use of terrestrial habitat when sea ice habitat is unavailable. } \\
\text { However, we note that in most cases, terrestrial food is not } \\
\text { available in sufficient quantity or nutrient content to } \\
\text { mitigate declines in body condition associated with bears } \\
\text { foregoing foraging on marine mammal prey. }\end{array}$ & $\begin{array}{l}\text { Elevated } \\
\text { Same as } \\
\text { Recent } \\
\text { Reduced } \\
\text { Absent }\end{array}$ \\
\hline $\begin{array}{l}\text { TerrRef } \\
{[4]}\end{array}$ & $\begin{array}{l}\text { Terrestrial } \\
\text { Refugia Quality }\end{array}$ & $\begin{array}{l}\text { This node characterizes stability in structure and freedom } \\
\text { from human and natural disturbance of a place where polar }\end{array}$ & $\begin{array}{l}\text { Improved } \\
\text { Not Degraded }\end{array}$ \\
\hline
\end{tabular}




\begin{tabular}{|c|c|c|c|}
\hline $\begin{array}{l}\text { Node } \\
\text { Name }\end{array}$ & Node Title & $\begin{array}{c}\text { Node Description } \\
\end{array}$ & States \\
\hline & & $\begin{array}{l}\text { bears can wait out the ice-minimum period, avoiding } \\
\text { excessive expenditure of energy. The characterization } \\
\text { includes quality of sites used for terrestrial non-maternal } \\
\text { denning, summertime denning, resting, and unobstructed } \\
\text { movement. Refugia quality can be compromised by } \\
\text { erosion, rock slides, fire (e.g., peat ridges adjacent to } \\
\text { Hudson Bay), reduction in consolidated glacial ice or } \\
\text { retraction of glaciers, and the presence of anthropogenic } \\
\text { infrastructure that inhibits movement and/or use of an area. } \\
\text { We note that terrestrial refuge is most important for the } \\
\text { SIE, where use of terrestrial habitat has long been a life } \\
\text { history characteristic, and the PBDE, where use of } \\
\text { terrestrial habitat is becoming more common. Degradation } \\
\text { of refugia quality by coastal erosion is a threat for the } \\
\text { PBDE, as is the presence of anthropogenic infrastructure. } \\
\text { Reduction of consolidated glacial ice and/or glacial } \\
\text { retraction is a threat in parts of the SIE, and possibly the } \\
\text { AE. }\end{array}$ & Degraded \\
\hline $\begin{array}{l}\text { HumPB } \\
{[7]}\end{array}$ & $\begin{array}{l}\text { Human-Bear } \\
\text { Sublethal } \\
\text { Interaction }\end{array}$ & $\begin{array}{l}\text { This includes sublethal disturbance that may increase as a } \\
\text { result of increased human-bear interactions due to food } \\
\text { stressed bears more frequently entering Arctic communities } \\
\text { (e.g., Born and others, 2011). Such takes can displace bears } \\
\text { from their preferred locations and reduce habitat quality. } \\
\text { This was separate from the similar interactions that may } \\
\text { occur around oil and gas or other industrial sites, which } \\
\text { also can displace bears and lower habitat quality. We } \\
\text { believe that bear-human interactions will increase as long } \\
\text { as the ice-minimum season increases. }\end{array}$ & $\begin{array}{l}\text { Elevated } \\
\text { Same as } \\
\text { Recent } \\
\text { Reduced }\end{array}$ \\
\hline $\begin{array}{l}\text { OilAcct } \\
{[7]}\end{array}$ & $\begin{array}{l}\text { Oil, Gas, and } \\
\text { Mining Activity }\end{array}$ & $\begin{array}{l}\text { This node characterizes the potential for oil, gas and } \\
\text { mining activity to influence the distribution of polar bears. } \\
\text { Specifically, it refers to activities and infrastructure that } \\
\text { may physically displace bears from habitat that was } \\
\text { formally available to them. Industry plans and agency } \\
\text { permitting activities indicate that oil and gas extraction and } \\
\text { exploration activity will increase in the polar basin region } \\
\text { through mid-century and then decline because resources } \\
\text { will have been tapped. We may see some increase in } \\
\text { exploration and development in the Archipelago, however, } \\
\text { as it becomes increasingly accessible. Industrial activity is } \\
\text { expected to be greatest for the near-shore region and along } \\
\text { coastlines. }\end{array}$ & $\begin{array}{l}\text { Elevated } \\
\text { Same as } \\
\text { Recent } \\
\text { Reduced }\end{array}$ \\
\hline $\begin{array}{l}\text { Ship } \\
\text { [7] }\end{array}$ & Shipping & $\begin{array}{l}\text { As sea ice extent declines spatially and temporally it is } \\
\text { predicted that shipping in Arctic regions will increase. } \\
\text { Increased shipping could lead to direct disturbances of } \\
\text { polar bears as well as to increased levels of contamination. } \\
\text { The best information available to assess the potential for } \\
\text { increased shipping activity relies on climate model } \\
\text { projections to determine potential navigability and season }\end{array}$ & $\begin{array}{l}\text { Elevated } \\
\text { Same as } \\
\text { Recent } \\
\text { Reduced }\end{array}$ \\
\hline
\end{tabular}




\begin{tabular}{|c|c|c|c|}
\hline $\begin{array}{l}\text { Node } \\
\text { Name }\end{array}$ & Node Title & $\begin{array}{c}\text { Node Description } \\
\end{array}$ & States \\
\hline & & $\begin{array}{l}\text { duration (e.g., Smith and Stephenson, 2013). It is predicted } \\
\text { that by mid-century, changing sea ice conditions will } \\
\text { enable expanded September navigability for common open- } \\
\text { water ships crossing the Arctic along the Northern Sea } \\
\text { Route, robust new routes for ice-strengthened ships, and } \\
\text { new routes through the Northwest Passage. As a result, } \\
\text { shipping activity is likely to affect a portion of all } \\
\text { ecoregions. Here, we address only the physical presence of } \\
\text { more vessel traffic. Contamination (e.g., bilge, oil, } \\
\text { wastewater), and biological effects from introduced } \\
\text { organisms that may compete with residents of the food web } \\
\text { or cause disease are covered under the nodes for } \\
\text { contamination and parasites and disease. } \\
\text { We note that shipping likely will increase in the foreseeable } \\
\text { future. That said, there may be variability in the distribution } \\
\text { of shipping activity based on route availability and } \\
\text { efficiencies made as trans-Arctic shipping becomes more } \\
\text { common. For example, even if international shipping does } \\
\text { not increase, local shipping will because barges and vessels } \\
\text { are more efficient ways to move fuel and freight into } \\
\text { remote Arctic locations than aircraft. }\end{array}$ & \\
\hline $\begin{array}{l}\text { Tour } \\
\text { [7] }\end{array}$ & Tourism & $\begin{array}{l}\text { As sea ice extent declines spatially and temporally, access } \\
\text { and opportunities for Arctic tourism also will increase. We } \\
\text { define tourism as including activities centered on polar } \\
\text { bears, such as recreational viewing, as well as general } \\
\text { recreational travel throughout polar bear habitat. Increased } \\
\text { tourism could lead to direct disturbances of polar bears as } \\
\text { well as to increased levels of contamination. Here, we } \\
\text { address only the physical presence of more tourism and the } \\
\text { conveyances used by tourists (vessels, land vehicles, } \\
\text { aircraft). We believe that tourism will increase in all areas } \\
\text { of the Arctic through the foreseeable future. }\end{array}$ & $\begin{array}{l}\text { Elevated } \\
\text { Same as } \\
\text { Recent } \\
\text { Reduced }\end{array}$ \\
\hline $\begin{array}{l}\text { OilSpill } \\
{[7]}\end{array}$ & $\begin{array}{l}\text { Hydrocarbons, } \\
\text { Oil Spill }\end{array}$ & $\begin{array}{l}\text { This node refers to the release of oil or oil related products } \\
\text { into polar bear habitat, defined here only as nonlethal and } \\
\text { displacement effects, including mortality of prey. Hence, it } \\
\text { has ramifications for both habitat quality and population } \\
\text { dynamics directly. Hydrocarbon exploration and } \\
\text { development are expanding and proposed to expand further } \\
\text { in the Arctic. Greater levels of such activity are most likely } \\
\text { to increase the probability of oil spills. Increased shipping } \\
\text { may result in higher levels of hydrocarbons released into } \\
\text { Arctic waters. }\end{array}$ & $\begin{array}{l}\text { Elevated } \\
\text { Same as } \\
\text { Recent } \\
\text { Reduced }\end{array}$ \\
\hline $\begin{array}{l}\text { Cont } \\
{[7]}\end{array}$ & Contaminants & $\begin{array}{l}\text { This node reflects the possible increase or decrease of } \\
\text { contamination in the Arctic as a result of modified } \\
\text { pathways. Contaminants can act to make habitat less } \\
\text { suitable and directly affect survival and reproduction. } \\
\text { Increased precipitation and glacial melt have recently } \\
\text { resulted in greater influx of contaminants into the Arctic }\end{array}$ & $\begin{array}{l}\text { Elevated } \\
\text { Same as } \\
\text { Recent } \\
\text { Reduced }\end{array}$ \\
\hline
\end{tabular}




\begin{tabular}{|c|c|c|c|}
\hline $\begin{array}{l}\text { Node } \\
\text { Name }\end{array}$ & Node Title & Node Description & States \\
\hline & & $\begin{array}{l}\text { region from the interior of Eurasia through large northward } \\
\text { flowing rivers. Melting of multi-year ice has released } \\
\text { previously bound contaminants into the environment (Ma } \\
\text { and others, 2011). Similarly, differing atmospheric } \\
\text { circulation patterns have altered potential pathways for } \\
\text { contaminants from lower latitudes. The record of reduction } \\
\text { and the persistence of many of these chemicals in the } \\
\text { environment suggests the greatest likelihood is for elevated } \\
\text { levels in the short to medium term with some probability of } \\
\text { stability or even declines far in the future. }\end{array}$ & \\
\hline $\begin{array}{l}D L P \\
{[7]}\end{array}$ & $\begin{array}{l}\text { Human-Bear } \\
\text { DLP Lethal } \\
\text { Interactions }\end{array}$ & $\begin{array}{l}\text { This node expresses change in the occurrence of human- } \\
\text { bear DLP (defense of life and property) interactions over } \\
\text { time. These interactions result in death, as when problem } \\
\text { bears are shot in defense of life and property. Human-bear } \\
\text { DLP interactions are a concern throughout the polar bear's } \\
\text { range and we believe that bear-human interactions will } \\
\text { increase as summer sea ice extent declines and until such } \\
\text { time that either areas are devoid of bears or climate cools } \\
\text { and ice returns. }\end{array}$ & $\begin{array}{l}\text { Elevated } \\
\text { Same as } \\
\text { Recent } \\
\text { Reduced }\end{array}$ \\
\hline $\begin{array}{l}\text { Hunt } \\
{[6]}\end{array}$ & $\begin{array}{l}\text { Hunting } \\
\text { Mortality }\end{array}$ & $\begin{array}{l}\text { This node represents direct mortality from legal hunting } \\
\text { alone, and includes subsistence use. These sources of } \\
\text { mortality are controllable by regulation. We expect hunting } \\
\text { mortality to occur for the foreseeable future across polar } \\
\text { bear range where hunting is legal. This is based on } \\
\text { importance of subsistence harvest to native communities } \\
\text { and the recognition by many management authorities that it } \\
\text { is important to maintain subsistence harvest as long as } \\
\text { possible. }\end{array}$ & $\begin{array}{l}\text { Elevated } \\
\text { Same as } \\
\text { Recent } \\
\text { Reduced }\end{array}$ \\
\hline $\begin{array}{l}\text { OilOpn } \\
{[6]}\end{array}$ & $\begin{array}{l}\text { Oil Spills, } \\
\text { Small } \\
\text { Operational }\end{array}$ & $\begin{array}{l}\text { This node refers to the occurrence of oil spills from small } \\
\text { extraction operations that would result in mortality of bears } \\
\text { directly affected by oiling. There is some indication that } \\
\text { activity by smaller operators is increasing in parts of the } \\
\text { PBDE. Spills from small operations are expected to be } \\
\text { relatively small in volume (e.g., }<6,000 \text { barrels; Amstrup } \\
\text { and others, 2006a) and limited in spatial scale and present a } \\
\text { risk at the scale of a proportion of a subpopulation. Polar } \\
\text { bears are often distributed over the continental shelf and } \\
\text { other shallow waters, areas that overlap oil extraction } \\
\text { activities. Because of this overlap, polar bears are at risk of } \\
\text { being exposed to oil spills. } \\
\text { Although this node primarily considers immediate, acute } \\
\text { lethal effects on polar bears, we also acknowledge that the } \\
\text { effects of an oil spill could persist for an extended period } \\
\text { (i.e., multiple years, given the ice formation-thaw cycle). } \\
\text { We also note that exposure to oil and related products } \\
\text { could have sublethal effects, which are accounted for in a } \\
\text { separate node. }\end{array}$ & $\begin{array}{l}\text { Elevated } \\
\text { Same as } \\
\text { Recent } \\
\text { Reduced }\end{array}$ \\
\hline OilExp & Oil Spill, Large & This node refers to the occurrence of oil spills from large & Elevated \\
\hline
\end{tabular}




\begin{tabular}{|c|c|c|c|}
\hline $\begin{array}{c}\text { Node } \\
\text { Name }\end{array}$ & Node Title & Node Description & States \\
\hline [6] & Exploratory & $\begin{array}{l}\text { exploration operations. Spills from these operations have } \\
\text { the potential to be large in spatial scale and although the } \\
\text { risk of a spill is diminished from that of small-scale } \\
\text { operators, if a spill were to occur, it could be catastrophic. } \\
\text { A catastrophic spill would present a risk at the scale of } \geq 1 \\
\text { subpopulation. } \\
\text { As with the "small operation" node, this node specifically } \\
\text { considers the risk of the release of oil or oil related } \\
\text { products into polar bear habitat that would result in } \\
\text { mortality of bears directly affected by oiling. Alhtough this } \\
\text { node primarily considers immediate, acute lethal effects on } \\
\text { polar bears, we also acknowledge that the effects of an oil } \\
\text { spill could persist for an extended period (i.e., multiple } \\
\text { years, given the ice formation-thaw cycle). We also note } \\
\text { that exposure to oil and related products could have } \\
\text { sublethal effects, which are accounted for in a separate } \\
\text { node. For a large spill, such effects are expected to persist } \\
\text { for decades, similar to the Exxon Valdez (Peterson and } \\
\text { others, } 2003 \text { ). We assumed that a catastrophic spill could } \\
\text { oil a significant proportion of one or more subpopulations } \\
\text { and have persistent (i.e., multi-year) lethal effects due to oil } \\
\text { being bound and re-released as part of the freeze-thaw } \\
\text { cycle of sea ice. }\end{array}$ & $\begin{array}{l}\text { Same as } \\
\text { Recent } \\
\text { Reduced }\end{array}$ \\
\hline $\begin{array}{l}\text { OthMor2 } \\
{[6]}\end{array}$ & $\begin{array}{l}\text { Other Events } \\
\text { (Lethal Effects) }\end{array}$ & $\begin{array}{l}\text { This node refers to the likelihood of mortality from various } \\
\text { sources, including illegal killing, drowning, den failure, and } \\
\text { management and research activities. Because there is little } \\
\text { data on cause-specific mortality of polar bears, the } \\
\text { probabilities for this node were developed based on expert } \\
\text { understandings of polar bears and their ecosystem. }\end{array}$ & $\begin{array}{l}\text { Elevated } \\
\text { Same as } \\
\text { Recent } \\
\text { Reduced }\end{array}$ \\
\hline $\begin{array}{l}\text { ParDis } \\
{[8]}\end{array}$ & $\begin{array}{l}\text { Parasites and } \\
\text { Disease }\end{array}$ & $\begin{array}{l}\text { This node reflects possible change in exposure to disease } \\
\text { and parasites that may result from changing environmental } \\
\text { conditions. As the climate warms, regions of the Arctic are } \\
\text { likely to become more hospitable to endemic and emerging } \\
\text { parasites and disease agents. It is believed that polar bears } \\
\text { have been free of most disease and parasite agents, but } \\
\text { comprehensive surveillance has been lacking. There is } \\
\text { evidence suggesting that polar bears are now exposed to a } \\
\text { variety of zoonotic agents and parasites including Brucella } \\
\text { abortus, Toxoplasma gondii, Coxiella burnettii, rabies, and } \\
\text { trichinella (e.g., Rah and others, 2005; Kirk and others, } \\
\text { 2011). It is also known that polar bears have a relatively } \\
\text { naive immune system (Weber and others, 2013), which } \\
\text { may make them vulnerable to invading pathogens. Changes } \\
\text { in other species' disease vulnerability suggest that similar } \\
\text { changes could occur in polar bears so that they could move } \\
\text { from a position where parasites and disease are not } \\
\text { influential on a population level to where they are } \\
\text { influential. }\end{array}$ & $\begin{array}{l}\text { Elevated } \\
\text { Same as } \\
\text { Recent } \\
\text { Reduced }\end{array}$ \\
\hline
\end{tabular}




\begin{tabular}{|c|c|c|c|}
\hline $\begin{array}{c}\text { Node } \\
\text { Name }\end{array}$ & Node Title & Node Description & States \\
\hline $\begin{array}{l}\text { Pred } \\
{[8]}\end{array}$ & Predation & $\begin{array}{l}\text { This node characterizes the likelihood of intra- and } \\
\text { interspecific predation over time and relative to changing } \\
\text { environmental conditions. Predation on polar bears by } \\
\text { other species is very uncommon partly because bears spend } \\
\text { almost all of their time on the ice. With more time on land, } \\
\text { polar bears, especially young will be subject to increased } \\
\text { levels of predation from other polar bears, wolves, and } \\
\text { perhaps grizzly bears. Increased use of land during } \\
\text { summer, and a growing reliance on scavenging beach-cast } \\
\text { and aggregated marine mammals, may put younger bears at } \\
\text { greater risk of lethal encounters with adults. Local } \\
\text { ecological knowledge suggests that most cases of predation } \\
\text { involve adult males killing cubs of the year (e.g., Born and } \\
\text { others, 2011). } \\
\text { Recent observations of predation on other bears by large } \\
\text { males, in regions where it has not been observed before, are } \\
\text { consistent with the hypothesis that this sort of behavior } \\
\text { may increase in frequency if polar bears are nutritionally } \\
\text { stressed. At present, intraspecific predation is not thought } \\
\text { to be influential at the population level anywhere in the } \\
\text { polar bear range, though it appears that the frequency of } \\
\text { such events may be increasing. }\end{array}$ & $\begin{array}{l}\text { Elevated } \\
\text { Same as } \\
\text { Recent } \\
\text { Reduced }\end{array}$ \\
\hline \multicolumn{4}{|l|}{$\begin{array}{l}\text { Intermediate } \\
\text { Nodes }\end{array}$} \\
\hline $\begin{array}{l}\text { PrimPrey } \\
{[3]}\end{array}$ & $\begin{array}{l}\text { Primary Prey } \\
\text { Abundance }\end{array}$ & $\begin{array}{l}\text { This node is informed by the "ringed seal abundance" and } \\
\text { "bearded seal abundance" nodes. Ringed and bearded seals are } \\
\text { considered primary prey for polar bears based on the findings } \\
\text { of numerous studies of diet composition (e.g., Thiemann and } \\
\text { others, 2008) and prey selection (Pilfold and others, 2012). } \\
\text { This node expresses changes in primary prey abundance that } \\
\text { are likely to occur as sea ice cover declines and its physical } \\
\text { character changes. This is largely expert opinion because there } \\
\text { is little information available regarding the potential for future } \\
\text { changes in the prey base. However, recent work (e.g., Iacozza } \\
\text { and Ferguson, 2014) suggests that decreased future snow } \\
\text { depth over ice may have significant consequences to ringed } \\
\text { seal abundance through reduced pup survival. Such an } \\
\text { outcome is most likely for the SIE and PBDE. As ice thins in } \\
\text { the AE, it is reasonable to expect a transient increase in the } \\
\text { abundance of primary prey, perhaps until the mid-century } \\
\text { mark, followed by a decline as sea ice cover once again } \\
\text { becomes limiting. } \\
\text { Based on the literature, we weighted the relative importance } \\
\text { of ringed and bearded seals in developing the probabilities for } \\
\text { this table. Given that ringed seals usually represent a greater } \\
\text { proportion of polar bear diet (e.g., Born and others, 2011), and } \\
\text { are likely more available to all age and sex classes than } \\
\text { bearded seals, it received a greater weight (0.6). }\end{array}$ & $\begin{array}{l}\text { Elevated } \\
\text { Same as } \\
\text { Recent } \\
\text { Reduced }\end{array}$ \\
\hline
\end{tabular}




\begin{tabular}{|c|c|c|c|}
\hline $\begin{array}{r}\text { Node } \\
\text { Name }\end{array}$ & Node Title & Node Description & States \\
\hline $\begin{array}{l}\text { MrnPry } \\
{[3]}\end{array}$ & $\begin{array}{l}\text { Marine Prey } \\
\text { Base Quality }\end{array}$ & $\begin{array}{l}\text { This node expresses changes in primary and secondary } \\
\text { prey abundance that are likely to occur as sea ice cover } \\
\text { declines and its physical character changes. As with the } \\
\text { prey nodes, the probabilities for this node are largely based } \\
\text { on expert opinion because there is little information } \\
\text { available to suggest how the prey base is likely to change in } \\
\text { the future. In developing the probabilities for this node, } \\
\text { primary prey was given slightly greater weight than } \\
\text { secondary prey because the importance of primary prey has } \\
\text { been established in the literature, although there is } \\
\text { relatively little information available on the } \\
\text { likelihood/importance of prey switching. However, there is } \\
\text { evidence (e.g., Peacock and others, 2013) to suggest that } \\
\text { increased abundance of alternate prey may elevate total } \\
\text { survival of polar bears. }\end{array}$ & $\begin{array}{l}\text { Elevated } \\
\text { Same as } \\
\text { Recent } \\
\text { Reduced }\end{array}$ \\
\hline $\begin{array}{l}\text { Ice } \\
{[2]}\end{array}$ & $\begin{array}{l}\text { Overall Sea Ice } \\
\text { Conditions }\end{array}$ & $\begin{array}{l}\text { This node expresses the combination of the quantitative } \\
\text { and qualitative ways the retreat of sea ice may affect use of } \\
\text { continental shelf habitats. Analyses indicate that, in } \\
\text { addition to reductions of total ice extent (expressed under } \\
\text { IceArea), we will see seasonal retreats of the sea ice } \\
\text { (IceFor) away from coastal areas now preferred by polar } \\
\text { bears, and these retreats (or ice free periods) are projected } \\
\text { to progressively become longer. These changes will affect } \\
\text { polar bears by reducing the total availability of ice } \\
\text { substrate, altering the spatial distribution of foraging } \\
\text { patches, and making ice unavailable for extended periods in } \\
\text { many regions year-round. These changes may lead to a } \\
\text { shift from year-round to seasonal occupancy in affected } \\
\text { areas. We defined "greatly reduced" overall sea ice } \\
\text { conditions as when "foraging sea ice area" was }<-40 \text { square } \\
\text { kilometer months and the availability of "foraging sea ice } \\
\text { distribution" was greatly reduced. } \\
\text { Note that because the PBCE includes populations that have } \\
\text { different starting values for overall sea ice conditions, the } \\
\text { values in the CPT express an average- similar to the } \\
\text { approach taken for this area when estimating values for } \\
\text { IceFor. Similarly, in the SIE, there is a difference between } \\
\text { several populations, so table values are an average. }\end{array}$ & $\begin{array}{l}\text { Improved } \\
\text { Same as } \\
\text { Recent } \\
\text { Reduced } \\
\text { Greatly } \\
\text { Reduced }\end{array}$ \\
\hline $\begin{array}{l}\text { IceFor } \\
{[2]}\end{array}$ & $\begin{array}{l}\text { Foraging Sea } \\
\text { Ice Distribution }\end{array}$ & $\begin{array}{l}\text { This node combines the influence of Sea Ice Shelf Distance } \\
\text { Change (IceShelf), Foraging Sea Ice }<50 \text { percent Absence } \\
\text { Change (IceChng), and Ecoregion (EcoReg), expressing } \\
\text { how the spatiotemporal retreat of sea ice may affect use of } \\
\text { continental shelf habitats. Our analyses indicate we will see } \\
\text { seasonal retreats of the sea ice farther away from coastal } \\
\text { areas now preferred by polar bears, and these retreats (or } \\
\text { ice free periods) are projected to progressively become } \\
\text { longer. These changes will make ice unavailable for } \\
\text { extended periods in many regions bears now occur year }\end{array}$ & $\begin{array}{l}\text { Improved } \\
\text { Same as } \\
\text { Recent } \\
\text { Reduced } \\
\text { Greatly } \\
\text { Reduced }\end{array}$ \\
\hline
\end{tabular}




\begin{tabular}{|c|c|c|c|}
\hline $\begin{array}{l}\text { Node } \\
\text { Name }\end{array}$ & Node Title & Node Description & States \\
\hline & & $\begin{array}{l}\text { round. This will result in the opportunity for seasonal } \\
\text { occupancy but not the year-round occupancy bears have } \\
\text { had in the past. } \\
\text { In addition, we assumed that if parent node IceShelf is } \\
>=800 \mathrm{~km} \text { then IceChng would almost always be greater } \\
\text { than } 1 \text { month and probably much more (regardless of the } \\
\text { distribution of patches) and perhaps in the neighborhood of } \\
\geq 3 \text { months. Thus, when IceShelf is }>=800 \mathrm{~km} \text {, there is a } \\
\text { good chance that sea ice phenology will be altered over } \\
\text { shelf regions and the distribution of foraging sea ice will be } \\
\text { greatly reduced. However, even if IceChng is }<3 \text { months, } \\
\text { the arrangement/juxtaposition of ice patches would be so } \\
\text { dynamic that patch availability would likely be greatly } \\
\text { reduced. Sahanatien and Derocher ( } 2012) \text { provide a good } \\
\text { assessment of how changing ice phenology and increased } \\
\text { fragmentation are likely to adversely affect access to } \\
\text { foraging habitat. }\end{array}$ & \\
\hline $\begin{array}{l}\text { Mrn } \\
{[3]}\end{array}$ & $\begin{array}{l}\text { Overall Marine } \\
\text { Conditions }\end{array}$ & $\begin{array}{l}\text { This node expresses how quantitative changes in sea ice } \\
\text { and qualitative changes in prey base quality act in } \\
\text { combination to determine overall conditions in the marine } \\
\text { ecosystem. In developing the CPT for this node, we gave } \\
\text { greater weight of importance to "overall sea ice conditions" } \\
\text { because sea ice coverage influences access to prey. } \\
\text { Evidence suggests that polar bears prefer sea ice habitats } \\
\text { over or adjacent to coastal areas (e.g., Ferguson and others, } \\
\text { 2000, Durner and others, 2009). Seasonal retreat of sea ice } \\
\text { away from coastal areas reduces access to prey. The ice- } \\
\text { minimum period is projected to become longer through } \\
\text { time, which will further reduce access to prey present in } \\
\text { productive shallow waters. Thus, even though prey } \\
\text { abundance may remain stable, access to prey will decline in } \\
\text { response to declining seasonal sea ice extent. As access to } \\
\text { prey declines, so will overall marine conditions. }\end{array}$ & $\begin{array}{l}\text { Improved } \\
\text { Same as } \\
\text { Recent } \\
\text { Reduced }\end{array}$ \\
\hline $\begin{array}{l}\text { Len } \\
{[4]}\end{array}$ & Bears on Shore & $\begin{array}{l}\text { This node expresses the length of time each year that bears } \\
\text { may spend on shore exploiting terrestrial habitat. As overall } \\
\text { sea ice conditions decline, we expect greater use of onshore } \\
\text { habitat by bears as posited by Schliebe and others (2008). } \\
\text { Moreover, the likelihood of bears using onshore habitat } \\
\text { increases when the availability of terrestrial food resources } \\
\text { increases. However, using the SIE as evidence, we believe } \\
\text { the primary driver of onshore occurrence is the } \\
\text { absence/reduced availability of summer sea ice. We } \\
\text { defined "greatly increased" as a condition where the } \\
\text { majority of bears in a given ecoregion spend the majority } \\
\text { of the annual period on shore. } \\
\text { Characterization of the use of onshore habitat is } \\
\text { particularly important for the SIE, where use of onshore }\end{array}$ & $\begin{array}{l}\text { Greatly } \\
\text { Increased } \\
\text { Increased } \\
\text { Same as } \\
\text { Recent } \\
\text { Less than } \\
\text { Recent }\end{array}$ \\
\hline
\end{tabular}




\begin{tabular}{|c|c|c|c|}
\hline $\begin{array}{l}\text { Node } \\
\text { Name }\end{array}$ & Node Title & Node Description & States \\
\hline & & $\begin{array}{l}\text { habitat has long been a part of bear life history. This node } \\
\text { also may be important for other ecoregions over time. For } \\
\text { example, in parts of the PBDE, bears are spending more } \\
\text { time on shore during the ice-minimum season. We expect } \\
\text { base conditions to vary by ecoregion. }\end{array}$ & \\
\hline $\begin{array}{l}\text { TerrPry } \\
{[4]}\end{array}$ & $\begin{array}{l}\text { Overall } \\
\text { Terrestrial } \\
\text { Prey/Food } \\
\text { Availability }\end{array}$ & $\begin{array}{l}\text { This node characterizes the availability of food resources } \\
\text { relative to requirements of bears during their stay on shore. } \\
\text { The node is informed by "human-provisioned food } \\
\text { availability" and "terrestrial and marine prey access" and, } \\
\text { in turn, influences the length of time bears may spend on } \\
\text { shore during the ice-minimum season. In developing the } \\
\text { CPT for this node, we relied on expert knowledge and put } \\
\text { equal weight on both informing nodes. We noted that } \\
\text { "human provisioned food availability" is mostly relevant to } \\
\text { the PBDE and SIE. }\end{array}$ & $\begin{array}{l}\text { Elevated } \\
\text { Same as } \\
\text { Recent } \\
\text { Reduced } \\
\text { Absent }\end{array}$ \\
\hline $\begin{array}{l}\text { Hunt } \\
\text { [6] }\end{array}$ & $\begin{array}{l}\text { Hunting } \\
\text { Mortality } \\
\text { (legal) }\end{array}$ & $\begin{array}{l}\text { This node represents direct mortality from legal hunting } \\
\text { alone, and includes subsistence use. These sources of } \\
\text { mortality are controllable by regulation. We expect hunting } \\
\text { mortality to occur for the foreseeable future across polar } \\
\text { bear range where hunting is legal. This is based on } \\
\text { importance of subsistence harvest to native communities } \\
\text { and the recognition by many management authorities that it } \\
\text { is important to maintain subsistence harvest as long as } \\
\text { possible. }\end{array}$ & $\begin{array}{l}\text { Elevated } \\
\text { Same as base } \\
\text { Reduced }\end{array}$ \\
\hline $\begin{array}{l}\text { EvMort } \\
{[6]}\end{array}$ & $\begin{array}{l}\text { Event-Driven } \\
\text { Mortality }\end{array}$ & $\begin{array}{l}\text { This node expresses the combination of different forms of } \\
\text { mortality polar bears may be exposed to through time. } \\
\text { There was little information available on cause-specific } \\
\text { mortality of polar bears, so in developing the conditional } \\
\text { probability table we relied on expert knowledge to base } \\
\text { table entries on the relative importance of the different } \\
\text { forms of mortality. }\end{array}$ & $\begin{array}{l}\text { Elevated } \\
\text { Same as } \\
\text { Recent } \\
\text { Reduced }\end{array}$ \\
\hline $\begin{array}{l}\mathrm{Hab} \\
{[5]}\end{array}$ & $\begin{array}{l}\text { Overall Habitat } \\
\text { Suitability }\end{array}$ & $\begin{array}{l}\text { This node expresses overall habitat suitability as a } \\
\text { combination of the quality of marine and terrestrial habitats } \\
\text { used by polar bears. In developing the conditional } \\
\text { probability table for this node, greater importance was } \\
\text { given to "overall marine conditions" because polar bears } \\
\text { spend the majority of the year on sea ice foraging on } \\
\text { marine mammals. However, we note that over time, the use } \\
\text { of terrestrial habitat is likely to increase. The "greatly } \\
\text { reduced" state was defined as occurring when both overall } \\
\text { marine and terrestrial conditions were "degraded." } \\
\text { Based on projections of sea ice extent, we believe overall } \\
\text { sea ice conditions will degrade over time. One near-term } \\
\text { exception may be the AE, where climate-mediated } \\
\text { reductions in sea ice volume (through thinning of multi- } \\
\text { year ice) may result in a temporary improvement of } \\
\text { "overall marine conditions." We believe overall terrestrial } \\
\text { conditions are likely to change through time and further }\end{array}$ & $\begin{array}{l}\text { Elevated } \\
\text { Same as } \\
\text { Recent } \\
\text { Reduced } \\
\text { Greatly } \\
\text { Reduced }\end{array}$ \\
\hline
\end{tabular}




\begin{tabular}{|c|c|c|c|}
\hline $\begin{array}{l}\text { Node } \\
\text { Name }\end{array}$ & Node Title & Node Description & States \\
\hline & & $\begin{array}{l}\text { impact overall habitat suitability. There is some evidence to } \\
\text { suggest that polar bears may have the ability to forage } \\
\text { adaptively (e.g., Iverson and others, 2014), but it is unclear } \\
\text { if such foraging behavior can constitute a meaningful } \\
\text { energetic benefit. In the absence of such data, we } \\
\text { considered the contribution of "overall terrestrial } \\
\text { conditions" to be secondary to that of "overall marine } \\
\text { conditions." }\end{array}$ & \\
\hline $\begin{array}{l}\text { Terr } \\
{[4]}\end{array}$ & $\begin{array}{l}\text { Overall } \\
\text { Terrestrial } \\
\text { Conditions }\end{array}$ & $\begin{array}{l}\text { This node expresses change in overall terrestrial conditions } \\
\text { as a function of refugia quality and the length of time bears } \\
\text { spend on shore. Refugia quality expresses the ability of } \\
\text { bears to stay on shore and be free of disturbance. As } \\
\text { disturbance increases, refugia quality declines, which then } \\
\text { degrades overall terrestrial conditions. The length of time } \\
\text { spent on shore also influences overall terrestrial } \\
\text { conditions - the longer bears spend on shore, the more } \\
\text { likely that terrestrial conditions become degraded (e.g., } \\
\text { resource scarcity). The conditional probability table for this } \\
\text { node was populated based on expert knowledge, as there } \\
\text { are no data reflecting the relationship between refugia } \\
\text { quality, time spent on shore, and overall terrestrial } \\
\text { conditions. }\end{array}$ & $\begin{array}{l}\text { Improved } \\
\text { Same as } \\
\text { Recent } \\
\text { Degraded }\end{array}$ \\
\hline $\begin{array}{l}\text { OthMor } \\
{[6]}\end{array}$ & $\begin{array}{l}\text { Other Mortality } \\
\text { or Removal } \\
\text { Events }\end{array}$ & $\begin{array}{l}\text { This node refers to mortality from small- and large-scale oil } \\
\text { operations, and from a "catch-all" node of other mortality } \\
\text { event. The "other events" includes (but is not limited to) } \\
\text { drowning, illegal killing, den failure, and management and } \\
\text { research actions. } \\
\text { In developing the CPT, we attributed greater importance to } \\
\text { large oil spills given the potential for severe and lingering } \\
\text { lethal effects. }\end{array}$ & $\begin{array}{l}\text { Elevated } \\
\text { Same as } \\
\text { Recent } \\
\text { Reduced }\end{array}$ \\
\hline $\begin{array}{l}\text { AdSur } \\
\text { [9] }\end{array}$ & Adult Survival & $\begin{array}{l}\text { This node represents the sum of trends of adult survival. } \\
\text { This node is influenced by "overall habitat suitability," } \\
\text { "other biotic stressors," and "event-driven mortality." The } \\
\text { causal link between sea ice habitat and subadult survival is } \\
\text { based on the literature, which documents a relationship } \\
\text { between sea ice breakup and survival (Regehr and others, } \\
\text { 2007, 2010). In developing the conditional probability table } \\
\text { for this node, we gave "overall habitat suitability" greater } \\
\text { weight of importance than "event-driven mortality." We } \\
\text { justify the weighting scheme based on the preponderance } \\
\text { of the evidence suggesting that reductions in "overall } \\
\text { habitat suitability" will have the most profound effect on } \\
\text { persistence of polar bears. Although "event-driven } \\
\text { mortality" and "other biotic stressors" also will have } \\
\text { adverse effects, it is not expected to eclipse those of habitat } \\
\text { suitability. The "greatly reduced" state was defined as } \\
\text { occurring when survival was likely to exhibit a sustained } \\
\text { declining trend. }\end{array}$ & $\begin{array}{l}\text { Elevated } \\
\text { Same as } \\
\text { Recent } \\
\text { Reduced } \\
\text { Greatly } \\
\text { Reduced }\end{array}$ \\
\hline
\end{tabular}




\begin{tabular}{|c|c|c|c|}
\hline $\begin{array}{l}\text { Node } \\
\text { Name }\end{array}$ & Node Title & Node Description & States \\
\hline $\begin{array}{l}\text { SaSur } \\
{[9]}\end{array}$ & $\begin{array}{l}\text { Subadult } \\
\text { Survival }\end{array}$ & $\begin{array}{l}\text { This node represents the sum of trends of post-dependent } \\
\text { young (aged 2-4 years) surviving to be recruited into the } \\
\text { "adult" age class. This node is influenced by "overall } \\
\text { habitat suitability," "other biotic stressors," and "event- } \\
\text { driven mortality." As with "adult survival," the causal link } \\
\text { between sea ice habitat and subadult survival is based on } \\
\text { the literature, which documents a relationship between sea } \\
\text { ice breakup and survival (Regehr and others, 2007, 2010). } \\
\text { In developing the conditional probability table for this } \\
\text { node, we gave "overall habitat suitability" greater weight of } \\
\text { importance than "event-driven mortality." We justify the } \\
\text { weighting scheme based on the preponderance of the } \\
\text { evidence suggesting that reductions in "overall habitat } \\
\text { suitability" will have the most profound effect on } \\
\text { persistence of polar bears. Although "event-driven } \\
\text { mortality" and "other biotic stressors" also will have } \\
\text { adverse effects, those effects are not expected to eclipse } \\
\text { that of habitat suitability. The "greatly reduced" state was } \\
\text { defined as occurring when subadult survival was likely to } \\
\text { exhibit a sustained declining trend. }\end{array}$ & $\begin{array}{l}\text { Elevated } \\
\text { Same as } \\
\text { Recent } \\
\text { Reduced } \\
\text { Greatly } \\
\text { Reduced }\end{array}$ \\
\hline $\begin{array}{l}\text { AFBod } \\
{[9]}\end{array}$ & $\begin{array}{l}\text { Adult Female } \\
\text { Body Condition }\end{array}$ & $\begin{array}{l}\text { This node expresses how habitat conditions, sublethal } \\
\text { stressors, and some biotic stressors can influence the body } \\
\text { condition of adult females. In developing the conditional } \\
\text { probability table for this node, we gave "overall habitat } \\
\text { suitability" the greatest weight, acknowledging that } \\
\text { empirical evidence supports the link between declines in } \\
\text { sea ice habitat with declines in adult female body condition } \\
\text { (e.g., Rode and others, 2010). There is no information } \\
\text { available establishing a relationship between sublethal } \\
\text { effects or parasites and disease to polar bear body } \\
\text { condition. However, there is information for other species } \\
\text { (e.g., Pioz and others, 2008; Sheriff and others, 2009), and } \\
\text { we relied on that for guidance in completing the CPT. We } \\
\text { defined "greatly decreased" body condition as occurring } \\
\text { when declines in condition could lead to reproductive } \\
\text { failure. } \\
\text { We believe that sea ice projections support the notion that } \\
\text { "overall habitat suitability" is likely to decline through time } \\
\text { and thus adversely influence adult female body condition. } \\
\text { Likewise, there is supposition that exposure to parasites } \\
\text { and disease agents and other sublethal stressors is likely to } \\
\text { increase as the Arctic warms (e.g., Moore and Huntington, } \\
\text { 2008). Given that, we believe that adult female body } \\
\text { condition likely will decline in the future unless significant } \\
\text { mitigation measures to reduce GHGs are taken. }\end{array}$ & $\begin{array}{l}\text { Increased } \\
\text { Same as } \\
\text { Recent } \\
\text { Decreased } \\
\text { Greatly } \\
\text { Decreased }\end{array}$ \\
\hline $\begin{array}{l}\operatorname{DenAcc} \\
{[4]}\end{array}$ & $\begin{array}{l}\text { Terrestrial } \\
\text { Maternal Den } \\
\text { Access }\end{array}$ & $\begin{array}{l}\text { This node expresses change in maternal den access as a } \\
\text { function of changes to foraging sea ice absence. The } \\
\text { highest quality foraging sea ice is over and adjacent to }\end{array}$ & $\begin{array}{l}\text { Elevated } \\
\text { Same as } \\
\text { Recent }\end{array}$ \\
\hline
\end{tabular}




\begin{tabular}{|c|c|c|c|}
\hline $\begin{array}{l}\text { Node } \\
\text { Name } \\
\end{array}$ & Node Title & Node Description & States \\
\hline & & $\begin{array}{l}\text { productive shallow waters (i.e., continental shelf water). } \\
\text { These areas are generally close to coastal habitat and } \\
\text { provide easy access to terrestrial maternity dens. However, } \\
\text { climate warming has led to an increase in the length of the } \\
\text { ice-minimum season and an increase in the distance } \\
\text { between foraging sea ice and most coastal regions - the } \\
\text { exception being the Archipelago. If the distance between } \\
\text { foraging ice and the coast increases-as it is projected to- } \\
\text { then access to maternal dens may become restricted as } \\
\text { bears would have to cross expanses of open water to reach } \\
\text { onshore denning habitat. } \\
\text { Based on projections of sea ice extent and duration of the } \\
\text { ice-minimum season, we believe that access to terrestrial } \\
\text { denning habitat may become compromised in the future. } \\
\text { This is a more pressing concern for the PBDE than for } \\
\text { other areas, given the pattern of ice recession. }\end{array}$ & Reduced \\
\hline $\begin{array}{l}\text { Disturb } \\
{[7]}\end{array}$ & $\begin{array}{l}\text { Sub-lethal } \\
\text { Human } \\
\text { Disturbance }\end{array}$ & $\begin{array}{l}\text { This node expresses the combination of the changes in non- } \\
\text { lethal human disturbances to polar bears. Specifically, it } \\
\text { covers the direct bear-human interactions that can occur in } \\
\text { association with industrial development, tourism, and } \\
\text { shipping. We assumed bear-human interactions to be the } \\
\text { most influential factor. Although shipping and tourism } \\
\text { could become a significant problem, they also are issues } \\
\text { that could be subject to stringent regulations and flexible } \\
\text { management to minimize effects on bears. Similarly, oil } \\
\text { and gas companies can be subjected to appropriate } \\
\text { regulatory responses if bear-human interactions become too } \\
\text { frequent. Encounters in villages and hunting camps, } \\
\text { however, may not be as easily regulated and it seemed } \\
\text { more predictable they would lead to negative effects. } \\
\text { Increasing bear human interactions will result in } \\
\text { conditioned bears; however, direct bear mortality is not } \\
\text { included in this node. } \\
\text { We expect that the magnitude of sub-lethal human } \\
\text { disturbance will vary seasonally and over time, with the } \\
\text { greatest effects occurring during the ice-minimum season, } \\
\text { and increasing as that season lengthens. }\end{array}$ & $\begin{array}{l}\text { Elevated } \\
\text { Same as } \\
\text { Recent } \\
\text { Reduced }\end{array}$ \\
\hline $\begin{array}{l}\text { Recr } \\
{[9]}\end{array}$ & Recruitment & $\begin{array}{l}\text { This node reflects the sum of trends in numbers of cubs } \\
\text { produced and the effect of retreating sea ice on the ability } \\
\text { of females to reach traditional denning areas. There is a } \\
\text { well-documented link between adult female body condition } \\
\text { and recruitment for many species, including polar bears } \\
\text { (e.g., Derocher and Stirling, 1995; Rode and others, 2010). } \\
\text { There also is information documenting the importance of } \\
\text { terrestrial denning habitat for polar bears in multiple } \\
\text { ecoregions (Fischbach and others, 2007; Richardson and } \\
\text { others, 2005; Andersen and others, 2012). "Greatly }\end{array}$ & $\begin{array}{l}\text { Increased } \\
\text { Same as } \\
\text { Recent } \\
\text { Decreased } \\
\text { Greatly } \\
\text { Decreased }\end{array}$ \\
\hline
\end{tabular}




\begin{tabular}{|c|c|c|c|}
\hline $\begin{array}{l}\text { Node } \\
\text { Name }\end{array}$ & Node Title & Node Description & States \\
\hline & & $\begin{array}{l}\text { decreased" was defined as the likelihood that the trend in } \\
\text { the number of cubs exhibited a sustained decline. } \\
\text { In developing the CPT for this node, we put greater weight } \\
\text { on the contribution of adult female body condition in } \\
\text { influencing recruitment. While we note that access to } \\
\text { terrestrial dens has the potential to become reduced over } \\
\text { time, as the ice-minimum season lengthens, we believe that } \\
\text { the increased ice-minimum season will continue to have a } \\
\text { greater adverse effect on adult female body condition. This } \\
\text { position is based on the relationship between sea ice and } \\
\text { condition as outlined by Rode and others }(2010) \text {. }\end{array}$ & \\
\hline $\begin{array}{l}\text { AntStr } \\
{[7]}\end{array}$ & $\begin{array}{l}\text { Anthropogenic } \\
\text { Stressors (Sub- } \\
\text { lethal) }\end{array}$ & $\begin{array}{l}\text { This node combines lethal and non-lethal anthropogenic } \\
\text { stressors. It includes factors (other than the changes in sea } \\
\text { ice quality and quantity), which may affect both habitat } \\
\text { suitability and population dynamics. Although quantitative } \\
\text { information is lacking on the effects of these stressors at } \\
\text { the population level, we know qualitatively of effects on } \\
\text { immune function, gene expression, and physiological } \\
\text { stress. Given that, table entries were based on expert } \\
\text { knowledge. }\end{array}$ & $\begin{array}{l}\text { Elevated } \\
\text { Same as } \\
\text { Recent } \\
\text { Reduced }\end{array}$ \\
\hline $\begin{array}{l}\text { Pol } \\
{[7]}\end{array}$ & $\begin{array}{l}\text { Pollution (Sub- } \\
\text { lethal) }\end{array}$ & $\begin{array}{l}\text { This node is the sum of pollution effects from hydrocarbon } \\
\text { discharges directly into Arctic waters and from other } \\
\text { pollutants brought to the Arctic from other parts of the } \\
\text { world. The U.S. Fish and Wildlife Service listing decision } \\
\text { for polar bears included pollution as one of the "other } \\
\text { factors" along with direct human bear interactions that may } \\
\text { displace bears or otherwise make habitats less satisfactory. } \\
\text { We viewed the main effect of pollution as a potential effect } \\
\text { on population dynamics, as it is likely to manifest as } \\
\text { adverse impacts to immune function, reproductive } \\
\text { performance, and survival. Although there is relatively } \\
\text { little empirical data on the effects of hydrocarbon exposure } \\
\text { on polar bears, information is available for other marine } \\
\text { mammals. There is a large body of literature on the effects } \\
\text { of contaminants on polar bears. Information from the } \\
\text { literature was used to inform table entries for this node. }\end{array}$ & $\begin{array}{l}\text { Elevated } \\
\text { Same as } \\
\text { Recent } \\
\text { Reduced }\end{array}$ \\
\hline $\begin{array}{l}\text { BioStr } \\
{[8]}\end{array}$ & $\begin{array}{l}\text { Other Biotic } \\
\text { Stressors }\end{array}$ & $\begin{array}{l}\text { This node expresses the changing vulnerability of polar } \\
\text { bears to diseases and parasites, and to potential increases of } \\
\text { intra- and interspecific predation. We recognize that } \\
\text { predation/cannibalism is currently rare. We also recognize } \\
\text { that while there is information summarizing exposure to } \\
\text { disease agents, there is little such information relative to } \\
\text { parasites-although there is no information that links these } \\
\text { stressors to effects on vital rates. Given that, the conditional } \\
\text { probability table for this node is based largely on expert } \\
\text { knowledge. }\end{array}$ & $\begin{array}{l}\text { Elevated } \\
\text { Same as } \\
\text { Recent } \\
\text { Reduced }\end{array}$ \\
\hline $\begin{array}{l}\text { Outcome } \\
\text { Node }\end{array}$ & & & \\
\hline
\end{tabular}




\begin{tabular}{|c|c|c|c|}
\hline $\begin{array}{l}\text { Node } \\
\text { Name }\end{array}$ & Node Title & Node Description & States \\
\hline $\begin{array}{l}\text { InflPopn } \\
{[10]}\end{array}$ & $\begin{array}{l}\text { Relative } \\
\text { Influence on } \\
\text { Population } \\
\text { Trend }\end{array}$ & $\begin{array}{l}\text { This node depicts the hypothesized relative influence of } \\
\text { stressors on population trend as referenced by estimated or } \\
\text { observed changes to abundance and distribution. The node } \\
\text { is informed by "adult survival," "subadult survival," and } \\
\text { "recruitment," and we gave the greatest weight to adult } \\
\text { survival because it is the least sensitive to change. As such, } \\
\text { it should take a substantial change in conditions to exert a } \\
\text { meaningful influence on adult survival. The outcome states } \\
\text { are qualitative because there is insufficient empirical data } \\
\text { from a majority of the } 19 \text { polar bear subpopulations (e.g., } \\
\text { Obbard and others, 2010) that would allow us to develop } \\
\text { quantitative thresholds for transitioning from one state to } \\
\text { another. As a result, we estimated the relative influence on } \\
\text { population trend similar to Jay and others (2011), Amstrup } \\
\text { and others (2008, 2010), and Johnson and others (2013) by } \\
\text { using transition thresholds that reflect qualitative changes } \\
\text { in abundance, distribution (i.e., use and selection of } \\
\text { ecosystem elements and features), and strength and } \\
\text { presence of stressors. }\end{array}$ & $\begin{array}{l}\text { Increased } \\
\text { Same as } \\
\text { Recent } \\
\text { Decreased } \\
\text { Greatly } \\
\text { Decreased }\end{array}$ \\
\hline \multicolumn{4}{|l|}{$\begin{array}{l}\text { Scenario } \\
\text { Nodes }\end{array}$} \\
\hline $\begin{array}{l}\mathrm{Per} \\
{[1]}\end{array}$ & Time Period & $\begin{array}{l}\text { The states for this node correspond to years - } 1985-1995 \\
\text { (historical), 2007-2012 (recent), 2020-2030 (early } \\
\text { century), 2045-2055 (mid-century), 2070-2080 (late } \\
\text { century), and 2090-2100 (end of century). }\end{array}$ & $\begin{array}{l}1985-1995 \\
2007-2012 \\
2020-2030 \\
2045-2055 \\
2070-2080 \\
2090-2100\end{array}$ \\
\hline $\begin{array}{l}\text { Scenario } \\
{[1]}\end{array}$ & $\begin{array}{l}\text { Forcing } \\
\text { Pahtway and } \\
\text { GCM Ensemble }\end{array}$ & $\begin{array}{l}\text { The states for this node correspond to the combination of } \\
\text { RCP (RCP } 4.5 \text { and } 8.5 \text {; van Vuuren and others, 2011) and } \\
\text { GCM ensemble. We used sea ice concentration outputs } \\
\text { from } 13 \text { GCMs that were produced by each of two CMIP5 } \\
\text { RCP forcing experiments. Hindcasts of monthly sea ice } \\
\text { concentration were obtained for each of the same } 13 \text { GCMs } \\
\text { from the CMIP5 'historical' forcing experiment. Historical } \\
\text { data consisted of satellite observations of monthly sea ice } \\
\text { concentration for 1985-2012. GCM outputs were } \\
\text { transformed and resampled (nearest neighbor) to a } 25-\mathrm{km}- \\
\text { resolution polar stereographic grid that was congruent to } \\
\text { the grid of sea ice observations. }\end{array}$ & $\begin{array}{l}\text { Satellite } \\
\text { RCP } 4.5 \\
\text { Frequency } \\
\text { RCP } 8.5 \\
\text { Frequency } \\
\text { RCP } 4.5 \\
\text { Mean } \\
\text { RCP } 8.5 \\
\text { Mean }\end{array}$ \\
\hline $\begin{array}{l}\text { Ecoreg } \\
\text { [2] }\end{array}$ & Ecoregion & $\begin{array}{l}\text { The states for this node correspond to the four ecoregions } \\
\text { proposed by Amstrup and others (2008). Ecoregions } \\
\text { represent an intermediate-scale spatial grouping (i.e., } \\
\text { between individual populations and the circumpolar } \\
\text { distribution) of polar bears based on observed and } \\
\text { forecasted patterns of sea ice dynamics and polar bear life } \\
\text { history. }\end{array}$ & $\begin{array}{l}\text { AE } \\
\text { PBCE } \\
\text { PBDE } \\
\text { SIE }\end{array}$ \\
\hline $\begin{array}{l}\text { GCMset } \\
{[1]}\end{array}$ & $\begin{array}{l}\text { GCM Set or } \\
\text { Subset }\end{array}$ & $\begin{array}{l}\text { The states for this node correspond to the CMIP5 GCM } \\
\text { model set or subset used to produce sea ice concentration } \\
\text { outputs. } 13 \text { GCM were chosen from the CMIP5 archive }\end{array}$ & $\begin{array}{l}\text { Satellite } \\
\text { GCM13Total } \\
\text { GCM11Wang }\end{array}$ \\
\hline
\end{tabular}




\begin{tabular}{|c|l|l|l|}
\hline $\begin{array}{c}\text { Node } \\
\text { Name }\end{array}$ & Node Title & \multicolumn{1}{c|}{ Node Description } & States \\
\hline & & $\begin{array}{l}\text { based on evaluations performed by Massonnet and others } \\
(2012) \text { and Wang and Overland (2013b). }\end{array}$ & GCM05Mass \\
\hline
\end{tabular}

Submodels (numbers denoted after each node name in the above table):

[1] Analysis scenario

[2] Sea ice submodel

[3] Marine prey and conditions submodel

[4] Terrestrial food/prey and conditions submodel

[5] Overall habitat suitability submodel

[6] Event-driven mortality submodel

[7] Anthropogenic stressors submodel

[8] Other biotic stressors submodel

[9] Demographic submodel

[10] Polar bear persistence submodel 


\section{Appendix D. Normative Scenarios (Using Expected Values of Input Conditions) Run on the Second Generation Model}

See section "Materials and Methods" in text for descriptions of ecoregions. Satellite, use of empirical satellite data for historical and recent time periods for quantifying sea ice cover; RCP, representative concentration pathway; freq, use of frequency distributions of global circulation model (GCM) outcomes; ens mean, use of ensemble means of GCM outcomes; NA, not applicable; GCM13Total, use of all available GCMs; GCM11Wang, use of GCM model subsets as suggested by Wang and Overland (2013b); GCM05Mass, use of GCM model subsets as suggested by Massonnet and others (2012).

\begin{tabular}{|c|c|c|c|c|}
\hline $\begin{array}{c}\text { Scenario } \\
\text { No. }\end{array}$ & Ecoregion & RCP & Time period & GCM set \\
\hline ScenNum & EcoReg & Scenario & Per & GCMset \\
\hline 1 & Archipelago & Satellite & historical (1985-1995) & NA \\
\hline 2 & Archipelago & Satellite & baseline (1996-2006) & NA \\
\hline 3 & Archipelago & Satellite & recent (2007-2012) & NA \\
\hline 4 & Polar Basin Convergent & Satellite & historical (1985-1995) & NA \\
\hline 5 & Polar Basin Convergent & Satellite & baseline (1996-2006) & NA \\
\hline 6 & Polar Basin Convergent & Satellite & recent (2007-2012) & NA \\
\hline 7 & Polar Basin Divergent & Satellite & historical (1985-1995) & NA \\
\hline 8 & Polar Basin Divergent & Satellite & baseline (1996-2006) & NA \\
\hline 9 & Polar Basin Divergent & Satellite & recent (2007-2012) & NA \\
\hline 10 & Seasonal Ice & Satellite & historical (1985-1995) & NA \\
\hline 11 & Seasonal Ice & Satellite & baseline (1996-2006) & NA \\
\hline 12 & Seasonal Ice & Satellite & recent (2007-2012) & NA \\
\hline 13 & Archipelago & RCP 4.5 freq & early century (2020-2030) & GCM13Total \\
\hline 14 & Archipelago & RCP 4.5 freq & mid-century (2045-2055) & GCM13Total \\
\hline 15 & Archipelago & $\mathrm{RCP} 4.5$ freq & late century (2070-2080) & GCM13Total \\
\hline 16 & Archipelago & RCP 4.5 freq & end of century (2090-2100) & GCM13Total \\
\hline 17 & Archipelago & RCP 8.5 freq & early century (2020-2030) & GCM13Total \\
\hline 18 & Archipelago & RCP 8.5 freq & mid-century (2045-2055) & GCM13Total \\
\hline 19 & Archipelago & RCP 8.5 freq & late century (2070-2080) & GCM13Total \\
\hline 20 & Archipelago & RCP 8.5 freq & end of century (2090-2100) & GCM13Total \\
\hline 21 & Archipelago & RCP 4.5 ens mean & early century (2020-2030) & GCM13Total \\
\hline 22 & Archipelago & RCP 4.5 ens mean & mid-century (2045-2055) & GCM13Total \\
\hline 23 & Archipelago & RCP 4.5 ens mean & late century (2070-2080) & GCM13Total \\
\hline 24 & Archipelago & RCP 4.5 ens mean & end of century (2090-2100) & GCM13Total \\
\hline 25 & Archipelago & RCP 8.5 ens mean & early century (2020-2030) & GCM13Total \\
\hline 26 & Archipelago & RCP 8.5 ens mean & mid-century (2045-2055) & GCM13Total \\
\hline 27 & Archipelago & RCP 8.5 ens mean & late century (2070-2080) & GCM13Total \\
\hline 28 & Archipelago & RCP 8.5 ens mean & end of century (2090-2100) & GCM13Total \\
\hline 29 & Polar Basin Convergent & RCP 4.5 freq & early century (2020-2030) & GCM13Total \\
\hline
\end{tabular}




\begin{tabular}{|c|c|c|c|c|}
\hline $\begin{array}{c}\text { Scenario } \\
\text { No. }\end{array}$ & Ecoregion & RCP & Time period & GCM set \\
\hline ScenNum & EcoReg & Scenario & Per & GCMset \\
\hline 30 & Polar Basin Convergent & RCP 4.5 freq & mid-century (2045-2055) & GCM13Total \\
\hline 31 & Polar Basin Convergent & RCP 4.5 freq & late century (2070-2080) & GCM13Total \\
\hline 32 & Polar Basin Convergent & RCP 4.5 freq & end of century (2090-2100) & GCM13Total \\
\hline 33 & Polar Basin Convergent & RCP 8.5 freq & early century (2020-2030) & GCM13Total \\
\hline 34 & Polar Basin Convergent & RCP 8.5 freq & mid-century (2045-2055) & GCM13Total \\
\hline 35 & Polar Basin Convergent & RCP 8.5 freq & late century (2070-2080) & GCM13Total \\
\hline 36 & Polar Basin Convergent & RCP 8.5 freq & end of century (2090-2100) & GCM13Total \\
\hline 37 & Polar Basin Convergent & RCP 4.5 ens mean & early century (2020-2030) & GCM13Total \\
\hline 38 & Polar Basin Convergent & RCP 4.5 ens mean & mid-century (2045-2055) & GCM13Total \\
\hline 39 & Polar Basin Convergent & RCP 4.5 ens mean & late century (2070-2080) & GCM13Total \\
\hline 40 & Polar Basin Convergent & RCP 4.5 ens mean & end of century (2090-2100) & GCM13Total \\
\hline 41 & Polar Basin Convergent & RCP 8.5 ens mean & early century (2020-2030) & GCM13Total \\
\hline 42 & Polar Basin Convergent & RCP 8.5 ens mean & mid-century (2045-2055) & GCM13Total \\
\hline 43 & Polar Basin Convergent & RCP 8.5 ens mean & late century (2070-2080) & GCM13Total \\
\hline 44 & Polar Basin Convergent & RCP 8.5 ens mean & end of century (2090-2100) & GCM13Total \\
\hline 45 & Polar Basin Divergent & RCP 4.5 freq & early century (2020-2030) & GCM13Total \\
\hline 46 & Polar Basin Divergent & RCP 4.5 freq & mid-century (2045-2055) & GCM13Total \\
\hline 47 & Polar Basin Divergent & RCP 4.5 freq & late century (2070-2080) & GCM13Total \\
\hline 48 & Polar Basin Divergent & RCP 4.5 freq & end of century (2090-2100) & GCM13Total \\
\hline 49 & Polar Basin Divergent & RCP 8.5 freq & early century (2020-2030) & GCM13Total \\
\hline 50 & Polar Basin Divergent & RCP 8.5 freq & mid-century (2045-2055) & GCM13Total \\
\hline 51 & Polar Basin Divergent & RCP 8.5 freq & late century (2070-2080) & GCM13Total \\
\hline 52 & Polar Basin Divergent & RCP 8.5 freq & end of century (2090-2100) & GCM13Total \\
\hline 53 & Polar Basin Divergent & RCP 4.5 ens mean & early century (2020-2030) & GCM13Total \\
\hline 54 & Polar Basin Divergent & RCP 4.5 ens mean & mid-century (2045-2055) & GCM13Total \\
\hline 55 & Polar Basin Divergent & RCP 4.5 ens mean & late century (2070-2080) & GCM13Total \\
\hline 56 & Polar Basin Divergent & RCP 4.5 ens mean & end of century (2090-2100) & GCM13Total \\
\hline 57 & Polar Basin Divergent & RCP 8.5 ens mean & early century (2020-2030) & GCM13Total \\
\hline 58 & Polar Basin Divergent & RCP 8.5 ens mean & mid-century (2045-2055) & GCM13Total \\
\hline 59 & Polar Basin Divergent & RCP 8.5 ens mean & late century (2070-2080) & GCM13Total \\
\hline 60 & Polar Basin Divergent & RCP 8.5 ens mean & end of century (2090-2100) & GCM13Total \\
\hline 61 & Seasonal Ice & RCP 4.5 freq & early century (2020-2030) & GCM13Total \\
\hline 62 & Seasonal Ice & RCP 4.5 freq & mid-century (2045-2055) & GCM13Total \\
\hline 63 & Seasonal Ice & RCP 4.5 freq & late century (2070-2080) & GCM13Total \\
\hline 64 & Seasonal Ice & RCP 4.5 freq & end of century (2090-2100) & GCM13Total \\
\hline 65 & Seasonal Ice & RCP 8.5 freq & early century (2020-2030) & GCM13Total \\
\hline 66 & Seasonal Ice & RCP 8.5 freq & mid-century (2045-2055) & GCM13Total \\
\hline 67 & Seasonal Ice & RCP 8.5 freq & late century (2070-2080) & GCM13Total \\
\hline
\end{tabular}




\begin{tabular}{|c|c|c|c|c|}
\hline $\begin{array}{c}\text { Scenario } \\
\text { No. }\end{array}$ & Ecoregion & RCP & Time period & GCM set \\
\hline ScenNum & EcoReg & Scenario & Per & GCMset \\
\hline 68 & Seasonal Ice & RCP 8.5 freq & end of century (2090-2100) & GCM13Total \\
\hline 69 & Seasonal Ice & RCP 4.5 ens mean & early century (2020-2030) & GCM13Total \\
\hline 70 & Seasonal Ice & RCP 4.5 ens mean & mid-century (2045-2055) & GCM13Total \\
\hline 71 & Seasonal Ice & RCP 4.5 ens mean & late century (2070-2080) & GCM13Total \\
\hline 72 & Seasonal Ice & RCP 4.5 ens mean & end of century (2090-2100) & GCM13Total \\
\hline 73 & Seasonal Ice & RCP 8.5 ens mean & early century (2020-2030) & GCM13Total \\
\hline 74 & Seasonal Ice & RCP 8.5 ens mean & mid-century (2045-2055) & GCM13Total \\
\hline 75 & Seasonal Ice & RCP 8.5 ens mean & late century (2070-2080) & GCM13Total \\
\hline 76 & Seasonal Ice & RCP 8.5 ens mean & end of century (2090-2100) & GCM13Total \\
\hline 77 & Archipelago & $\mathrm{RCP} 4.5$ freq & early century (2020-2030) & GCM11Wang \\
\hline 78 & Archipelago & $\mathrm{RCP} 4.5$ freq & mid-century (2045-2055) & GCM11Wang \\
\hline 79 & Archipelago & RCP 4.5 freq & late century $(2070-2080)$ & GCM11Wang \\
\hline 80 & Archipelago & $\mathrm{RCP} 4.5$ freq & end of century (2090-2100) & GCM11Wang \\
\hline 81 & Archipelago & RCP 8.5 freq & early century (2020-2030) & GCM11Wang \\
\hline 82 & Archipelago & RCP 8.5 freq & mid-century (2045-2055) & GCM11Wang \\
\hline 83 & Archipelago & RCP 8.5 freq & late century (2070-2080) & GCM11Wang \\
\hline 84 & Archipelago & RCP 8.5 freq & end of century (2090-2100) & GCM11Wang \\
\hline 85 & Archipelago & RCP 4.5 ens mean & early century (2020-2030) & GCM11Wang \\
\hline 86 & Archipelago & RCP 4.5 ens mean & mid-century (2045-2055) & GCM11Wang \\
\hline 87 & Archipelago & RCP 4.5 ens mean & late century (2070-2080) & GCM11Wang \\
\hline 88 & Archipelago & RCP 4.5 ens mean & end of century (2090-2100) & GCM11Wang \\
\hline 89 & Archipelago & RCP 8.5 ens mean & early century (2020-2030) & GCM11Wang \\
\hline 90 & Archipelago & RCP 8.5 ens mean & mid-century (2045-2055) & GCM11Wang \\
\hline 91 & Archipelago & RCP 8.5 ens mean & late century (2070-2080) & GCM11Wang \\
\hline 92 & Archipelago & RCP 8.5 ens mean & end of century (2090-2100) & GCM11Wang \\
\hline 93 & Polar Basin Convergent & RCP 4.5 freq & early century (2020-2030) & GCM11Wang \\
\hline 94 & Polar Basin Convergent & $\mathrm{RCP} 4.5$ freq & mid-century (2045-2055) & GCM11Wang \\
\hline 95 & Polar Basin Convergent & RCP 4.5 freq & late century (2070-2080) & GCM11Wang \\
\hline 96 & Polar Basin Convergent & RCP 4.5 freq & end of century (2090-2100) & GCM11Wang \\
\hline 97 & Polar Basin Convergent & RCP 8.5 freq & early century (2020-2030) & GCM11Wang \\
\hline 98 & Polar Basin Convergent & RCP 8.5 freq & mid-century (2045-2055) & GCM11Wang \\
\hline 99 & Polar Basin Convergent & RCP 8.5 freq & late century (2070-2080) & GCM11Wang \\
\hline 100 & Polar Basin Convergent & $\mathrm{RCP} 8.5$ freq & end of century (2090-2100) & GCM11Wang \\
\hline 101 & Polar Basin Convergent & RCP 4.5 ens mean & early century (2020-2030) & GCM11Wang \\
\hline 102 & Polar Basin Convergent & $\mathrm{RCP} 4.5$ ens mean & mid-century (2045-2055) & GCM11Wang \\
\hline 103 & Polar Basin Convergent & RCP 4.5 ens mean & late century (2070-2080) & GCM11Wang \\
\hline 104 & Polar Basin Convergent & RCP 4.5 ens mean & end of century (2090-2100) & GCM11Wang \\
\hline 105 & Polar Basin Convergent & RCP 8.5 ens mean & early century (2020-2030) & GCM11Wang \\
\hline
\end{tabular}




\begin{tabular}{|c|c|c|c|c|}
\hline $\begin{array}{c}\begin{array}{c}\text { Scenario } \\
\text { No. }\end{array} \\
\end{array}$ & Ecoregion & RCP & Time period & GCM set \\
\hline ScenNum & EcoReg & Scenario & Per & GCMset \\
\hline 106 & Polar Basin Convergent & RCP 8.5 ens mean & mid-century (2045-2055) & GCM11Wang \\
\hline 107 & Polar Basin Convergent & RCP 8.5 ens mean & late century (2070-2080) & GCM11Wang \\
\hline 108 & Polar Basin Convergent & RCP 8.5 ens mean & end of century (2090-2100) & GCM11Wang \\
\hline 109 & Polar Basin Divergent & $\mathrm{RCP} 4.5$ freq & early century (2020-2030) & GCM11Wang \\
\hline 110 & Polar Basin Divergent & RCP 4.5 freq & mid-century (2045-2055) & GCM11Wang \\
\hline 111 & Polar Basin Divergent & RCP 4.5 freq & late century (2070-2080) & GCM11Wang \\
\hline 112 & Polar Basin Divergent & RCP 4.5 freq & end of century (2090-2100) & GCM11Wang \\
\hline 113 & Polar Basin Divergent & RCP 8.5 freq & early century (2020-2030) & GCM11Wang \\
\hline 114 & Polar Basin Divergent & RCP 8.5 freq & mid-century (2045-2055) & GCM11Wang \\
\hline 115 & Polar Basin Divergent & RCP 8.5 freq & late century (2070-2080) & GCM11Wang \\
\hline 116 & Polar Basin Divergent & RCP 8.5 freq & end of century (2090-2100) & GCM11Wang \\
\hline 117 & Polar Basin Divergent & RCP 4.5 ens mean & early century (2020-2030) & GCM11Wang \\
\hline 118 & Polar Basin Divergent & RCP 4.5 ens mean & mid-century (2045-2055) & GCM11Wang \\
\hline 119 & Polar Basin Divergent & RCP 4.5 ens mean & late century (2070-2080) & GCM11Wang \\
\hline 120 & Polar Basin Divergent & RCP 4.5 ens mean & end of century (2090-2100) & GCM11Wang \\
\hline 121 & Polar Basin Divergent & RCP 8.5 ens mean & early century (2020-2030) & GCM11Wang \\
\hline 122 & Polar Basin Divergent & RCP 8.5 ens mean & mid-century (2045-2055) & GCM11Wang \\
\hline 123 & Polar Basin Divergent & RCP 8.5 ens mean & late century (2070-2080) & GCM11Wang \\
\hline 124 & Polar Basin Divergent & RCP 8.5 ens mean & end of century (2090-2100) & GCM11Wang \\
\hline 125 & Seasonal Ice & RCP 4.5 freq & early century (2020-2030) & GCM11Wang \\
\hline 126 & Seasonal Ice & RCP 4.5 freq & mid-century (2045-2055) & GCM11Wang \\
\hline 127 & Seasonal Ice & RCP 4.5 freq & late century (2070-2080) & GCM11Wang \\
\hline 128 & Seasonal Ice & RCP 4.5 freq & end of century (2090-2100) & GCM11Wang \\
\hline 129 & Seasonal Ice & RCP 8.5 freq & early century (2020-2030) & GCM11Wang \\
\hline 130 & Seasonal Ice & RCP 8.5 freq & mid-century (2045-2055) & GCM11Wang \\
\hline 131 & Seasonal Ice & RCP 8.5 freq & late century (2070-2080) & GCM11Wang \\
\hline 132 & Seasonal Ice & RCP 8.5 freq & end of century (2090-2100) & GCM11Wang \\
\hline 133 & Seasonal Ice & RCP 4.5 ens mean & early century (2020-2030) & GCM11Wang \\
\hline 134 & Seasonal Ice & RCP 4.5 ens mean & mid-century (2045-2055) & GCM11Wang \\
\hline 135 & Seasonal Ice & RCP 4.5 ens mean & late century (2070-2080) & GCM11Wang \\
\hline 136 & Seasonal Ice & RCP 4.5 ens mean & end of century (2090-2100) & GCM11Wang \\
\hline 137 & Seasonal Ice & RCP 8.5 ens mean & early century (2020-2030) & GCM11Wang \\
\hline 138 & Seasonal Ice & RCP 8.5 ens mean & mid-century (2045-2055) & GCM11Wang \\
\hline 139 & Seasonal Ice & RCP 8.5 ens mean & late century (2070-2080) & GCM11Wang \\
\hline 140 & Seasonal Ice & RCP 8.5 ens mean & end of century (2090-2100) & GCM11Wang \\
\hline 141 & Archipelago & RCP 4.5 freq & early century (2020-2030) & GCM05Mass \\
\hline 142 & Archipelago & RCP 4.5 freq & mid-century (2045-2055) & GCM05Mass \\
\hline 143 & Archipelago & RCP 4.5 freq & late century (2070-2080) & GCM05Mass \\
\hline
\end{tabular}




\begin{tabular}{|c|c|c|c|c|}
\hline $\begin{array}{c}\text { Scenario } \\
\text { No. }\end{array}$ & Ecoregion & RCP & Time period & GCM set \\
\hline ScenNum & EcoReg & Scenario & Per & GCMset \\
\hline 144 & Archipelago & RCP 4.5 freq & end of century (2090-2100) & GCM05Mass \\
\hline 145 & Archipelago & RCP 8.5 freq & early century (2020-2030) & GCM05Mass \\
\hline 146 & Archipelago & RCP 8.5 freq & mid-century (2045-2055) & GCM05Mass \\
\hline 147 & Archipelago & RCP 8.5 freq & late century (2070-2080) & GCM05Mass \\
\hline 148 & Archipelago & RCP 8.5 freq & end of century (2090-2100) & GCM05Mass \\
\hline 149 & Archipelago & RCP 4.5 ens mean & early century (2020-2030) & GCM05Mass \\
\hline 150 & Archipelago & RCP 4.5 ens mean & mid-century (2045-2055) & GCM05Mass \\
\hline 151 & Archipelago & RCP 4.5 ens mean & late century (2070-2080) & GCM05Mass \\
\hline 152 & Archipelago & RCP 4.5 ens mean & end of century (2090-2100) & GCM05Mass \\
\hline 153 & Archipelago & RCP 8.5 ens mean & early century (2020-2030) & GCM05Mass \\
\hline 154 & Archipelago & RCP 8.5 ens mean & mid-century (2045-2055) & GCM05Mass \\
\hline 155 & Archipelago & RCP 8.5 ens mean & late century (2070-2080) & GCM05Mass \\
\hline 156 & Archipelago & RCP 8.5 ens mean & end of century (2090-2100) & GCM05Mass \\
\hline 157 & Polar Basin Convergent & RCP 4.5 freq & early century (2020-2030) & GCM05Mass \\
\hline 158 & Polar Basin Convergent & RCP 4.5 freq & mid-century (2045-2055) & GCM05Mass \\
\hline 159 & Polar Basin Convergent & RCP 4.5 freq & late century (2070-2080) & GCM05Mass \\
\hline 160 & Polar Basin Convergent & RCP 4.5 freq & end of century (2090-2100) & GCM05Mass \\
\hline 161 & Polar Basin Convergent & RCP 8.5 freq & early century (2020-2030) & GCM05Mass \\
\hline 162 & Polar Basin Convergent & RCP 8.5 freq & mid-century (2045-2055) & GCM05Mass \\
\hline 163 & Polar Basin Convergent & RCP 8.5 freq & late century (2070-2080) & GCM05Mass \\
\hline 164 & Polar Basin Convergent & RCP 8.5 freq & end of century (2090-2100) & GCM05Mass \\
\hline 165 & Polar Basin Convergent & RCP 4.5 ens mean & early century (2020-2030) & GCM05Mass \\
\hline 166 & Polar Basin Convergent & RCP 4.5 ens mean & mid-century (2045-2055) & GCM05Mass \\
\hline 167 & Polar Basin Convergent & RCP 4.5 ens mean & late century (2070-2080) & GCM05Mass \\
\hline 168 & Polar Basin Convergent & RCP 4.5 ens mean & end of century (2090-2100) & GCM05Mass \\
\hline 169 & Polar Basin Convergent & RCP 8.5 ens mean & early century (2020-2030) & GCM05Mass \\
\hline 170 & Polar Basin Convergent & RCP 8.5 ens mean & mid-century (2045-2055) & GCM05Mass \\
\hline 171 & Polar Basin Convergent & RCP 8.5 ens mean & late century (2070-2080) & GCM05Mass \\
\hline 172 & Polar Basin Convergent & RCP 8.5 ens mean & end of century (2090-2100) & GCM05Mass \\
\hline 173 & Polar Basin Divergent & RCP 4.5 freq & early century (2020-2030) & GCM05Mass \\
\hline 174 & Polar Basin Divergent & RCP 4.5 freq & mid-century (2045-2055) & GCM05Mass \\
\hline 175 & Polar Basin Divergent & RCP 4.5 freq & late century (2070-2080) & GCM05Mass \\
\hline 176 & Polar Basin Divergent & RCP 4.5 freq & end of century (2090-2100) & GCM05Mass \\
\hline 177 & Polar Basin Divergent & RCP 8.5 freq & early century (2020-2030) & GCM05Mass \\
\hline 178 & Polar Basin Divergent & RCP 8.5 freq & mid-century (2045-2055) & GCM05Mass \\
\hline 179 & Polar Basin Divergent & RCP 8.5 freq & late century (2070-2080) & GCM05Mass \\
\hline 180 & Polar Basin Divergent & RCP 8.5 freq & end of century (2090-2100) & GCM05Mass \\
\hline 181 & Polar Basin Divergent & RCP 4.5 ens mean & early century (2020-2030) & GCM05Mass \\
\hline
\end{tabular}




\begin{tabular}{|c|c|c|c|c|}
\hline $\begin{array}{c}\text { Scenario } \\
\text { No. }\end{array}$ & Ecoregion & RCP & Time period & GCM set \\
\hline ScenNum & EcoReg & Scenario & Per & GCMset \\
\hline 182 & Polar Basin Divergent & RCP 4.5 ens mean & mid-century (2045-2055) & GCM05Mass \\
\hline 183 & Polar Basin Divergent & RCP 4.5 ens mean & late century (2070-2080) & GCM05Mass \\
\hline 184 & Polar Basin Divergent & RCP 4.5 ens mean & end of century (2090-2100) & GCM05Mass \\
\hline 185 & Polar Basin Divergent & RCP 8.5 ens mean & early century (2020-2030) & GCM05Mass \\
\hline 186 & Polar Basin Divergent & RCP 8.5 ens mean & mid-century (2045-2055) & GCM05Mass \\
\hline 187 & Polar Basin Divergent & RCP 8.5 ens mean & late century (2070-2080) & GCM05Mass \\
\hline 188 & Polar Basin Divergent & RCP 8.5 ens mean & end of century (2090-2100) & GCM05Mass \\
\hline 189 & Seasonal Ice & RCP 4.5 freq & early century (2020-2030) & GCM05Mass \\
\hline 190 & Seasonal Ice & RCP 4.5 freq & mid-century (2045-2055) & GCM05Mass \\
\hline 191 & Seasonal Ice & RCP 4.5 freq & late century (2070-2080) & GCM05Mass \\
\hline 192 & Seasonal Ice & RCP 4.5 freq & end of century (2090-2100) & GCM05Mass \\
\hline 193 & Seasonal Ice & RCP 8.5 freq & early century (2020-2030) & GCM05Mass \\
\hline 194 & Seasonal Ice & RCP 8.5 freq & mid-century (2045-2055) & GCM05Mass \\
\hline 195 & Seasonal Ice & RCP 8.5 freq & late century (2070-2080) & GCM05Mass \\
\hline 196 & Seasonal Ice & RCP 8.5 freq & end of century (2090-2100) & GCM05Mass \\
\hline 197 & Seasonal Ice & RCP 4.5 ens mean & early century (2020-2030) & GCM05Mass \\
\hline 198 & Seasonal Ice & RCP 4.5 ens mean & mid-century (2045-2055) & GCM05Mass \\
\hline 199 & Seasonal Ice & RCP 4.5 ens mean & late century (2070-2080) & GCM05Mass \\
\hline 200 & Seasonal Ice & RCP 4.5 ens mean & end of century (2090-2100) & GCM05Mass \\
\hline 201 & Seasonal Ice & RCP 8.5 ens mean & early century (2020-2030) & GCM05Mass \\
\hline 202 & Seasonal Ice & RCP 8.5 ens mean & mid-century (2045-2055) & GCM05Mass \\
\hline 203 & Seasonal Ice & RCP 8.5 ens mean & late century (2070-2080) & GCM05Mass \\
\hline 204 & Seasonal Ice & RCP 8.5 ens mean & end of century (2090-2100) & GCM05Mass \\
\hline
\end{tabular}




\section{Appendix E. Conditional Probability Tables for Each Summary (i.e., Intermediate) Node in the Bayesian Network Model}

Tables E1-E20 are the conditional probability tables for each intermediate node in the Bayesian network model.

E1. Primary Prey Abundance.

\begin{tabular}{|l|l|c|c|c|}
\hline $\begin{array}{c}\text { Ringed Seal } \\
\text { Abundance }\end{array}$ & \multicolumn{1}{|c|}{$\begin{array}{c}\text { Bearded Seal } \\
\text { Abundance }\end{array}$} & Elevated & Same as Recent & Reduced \\
\hline elevated & elevated & 100 & 0 & 0 \\
\hline elevated & same as recent & 70 & 30 & 0 \\
\hline elevated & reduced & 50 & 50 & 0 \\
\hline same as recent & elevated & 40 & 60 & 0 \\
\hline same as recent & same as recent & 0 & 100 & 0 \\
\hline same as recent & reduced & 0 & 60 & 50 \\
\hline reduced & elevated & 0 & 50 & 70 \\
\hline reduced & same as recent & 0 & 30 & 100 \\
\hline reduced & reduced & 0 & 0 & \\
\hline
\end{tabular}

E2. Marine Prey Base Quality.

\begin{tabular}{|l|l|c|c|c|}
\hline $\begin{array}{c}\text { Primary Prey } \\
\text { Abundance }\end{array}$ & $\begin{array}{c}\text { Secondary and New } \\
\text { Prey Abundance }\end{array}$ & Elevated & Same as Recent & Reduced \\
\hline elevated & elevated & 100 & 0 & 0 \\
\hline elevated & same as recent & 90 & 10 & 0 \\
\hline elevated & reduced & 80 & 20 & 0 \\
\hline same as recent & elevated & 25 & 75 & 0 \\
\hline same as recent & same as recent & 0 & 100 & 20 \\
\hline same as recent & reduced & 0 & 80 & 40 \\
\hline reduced & elevated & 10 & 50 & 80 \\
\hline reduced & same as recent & 0 & 20 & 100 \\
\hline reduced & reduced & 0 & 0 & \\
\hline
\end{tabular}

E3. Overall Sea Ice Conditions.

\begin{tabular}{|l|l|l|c|c|c|c|}
\hline $\begin{array}{c}\text { Foraging } \\
\text { Sea Ice Area }\end{array}$ & \multicolumn{1}{|c|}{$\begin{array}{c}\text { Foraging Sea Ice } \\
\text { Distribution }\end{array}$} & $\begin{array}{c}\text { Foraging Sea Ice } \\
\text { Quality }\end{array}$ & Improved & $\begin{array}{c}\text { Same as } \\
\text { Base }\end{array}$ & Reduced & $\begin{array}{c}\text { Greatly } \\
\text { Reduced }\end{array}$ \\
\hline$>=0$ & improved availability & elevated & 100 & 0 & 0 & 0 \\
\hline$>=0$ & improved availability & same as recent & 100 & 0 & 0 & 0 \\
\hline$>=0$ & improved availability & reduced & 80 & 10 & 10 & 0 \\
\hline$>=0$ & same as recent & elevated & 90 & 10 & 0 & 0 \\
\hline$>=0$ & same as recent & same as recent & 60 & 40 & 0 & 0 \\
\hline$>=0$ & same as recent & reduced & 20 & 70 & 10 & 0 \\
\hline$>=0$ & reduced avail & elevated & 40 & 40 & 20 & 0 \\
\hline$>=0$ & reduced avail & same as recent & 20 & 60 & 20 & 0 \\
\hline$>=0$ & reduced avail & reduced & 0 & 20 & 60 & 20 \\
\hline
\end{tabular}




\begin{tabular}{|c|c|c|c|c|c|c|}
\hline $\begin{array}{l}\text { Foraging } \\
\text { Sea Ice Area }\end{array}$ & $\begin{array}{c}\text { Foraging Sea Ice } \\
\text { Distribution }\end{array}$ & $\begin{array}{c}\text { Foraging Sea Ice } \\
\text { Quality }\end{array}$ & Improved & $\begin{array}{l}\text { Same as } \\
\text { Base }\end{array}$ & Reduced & $\begin{array}{c}\text { Greatly } \\
\text { Reduced }\end{array}$ \\
\hline$>=0$ & greatly reduced avail & elevated & 5 & 45 & 30 & 20 \\
\hline$>=0$ & greatly reduced avail & same as recent & 0 & 20 & 30 & 50 \\
\hline$>=0$ & greatly reduced avail & reduced & 0 & 0 & 20 & 80 \\
\hline-5 to 0 & improved availability & elevated & 90 & 10 & 0 & 0 \\
\hline-5 to 0 & improved availability & same as recent & 80 & 20 & 0 & 0 \\
\hline-5 to 0 & improved availability & reduced & 50 & 30 & 20 & 0 \\
\hline-5 to 0 & same as recent & elevated & 20 & 75 & 5 & 0 \\
\hline-5 to 0 & same as recent & same as recent & 0 & 90 & 10 & 0 \\
\hline-5 to 0 & same as recent & reduced & 0 & 60 & 40 & 0 \\
\hline-5 to 0 & reduced avail & elevated & 10 & 50 & 40 & 0 \\
\hline-5 to 0 & reduced avail & same as recent & 0 & 40 & 60 & 0 \\
\hline-5 to 0 & reduced avail & reduced & 0 & 20 & 70 & 10 \\
\hline-5 to 0 & greatly reduced avail & elevated & 0 & 10 & 80 & 10 \\
\hline-5 to 0 & greatly reduced avail & same as recent & 0 & 5 & 65 & 30 \\
\hline-5 to 0 & greatly reduced avail & reduced & 0 & 0 & 40 & 60 \\
\hline-10 to -5 & improved availability & elevated & 90 & 10 & 0 & 0 \\
\hline-10 to -5 & improved availability & same as recent & 60 & 40 & 0 & 0 \\
\hline-10 to -5 & improved availability & reduced & 50 & 40 & 10 & 0 \\
\hline-10 to -5 & same as recent & elevated & 40 & 50 & 10 & 0 \\
\hline-10 to -5 & same as recent & same as recent & 10 & 80 & 10 & 0 \\
\hline-10 to -5 & same as recent & reduced & 0 & 20 & 80 & 0 \\
\hline-10 to -5 & reduced avail & elevated & 10 & 40 & 50 & 0 \\
\hline-10 to -5 & reduced avail & same as recent & 0 & 30 & 60 & 10 \\
\hline-10 to -5 & reduced avail & reduced & 0 & 0 & 70 & 30 \\
\hline-10 to -5 & greatly reduced avail & elevated & 0 & 10 & 60 & 30 \\
\hline-10 to -5 & greatly reduced avail & same as recent & 0 & 5 & 50 & 45 \\
\hline-10 to -5 & greatly reduced avail & reduced & 0 & 0 & 20 & 80 \\
\hline-20 to -10 & improved availability & elevated & 50 & 40 & 10 & 0 \\
\hline-20 to -10 & improved availability & same as recent & 20 & 60 & 20 & 0 \\
\hline-20 to -10 & improved availability & reduced & 10 & 40 & 50 & 0 \\
\hline-20 to -10 & same as recent & elevated & 20 & 60 & 20 & 0 \\
\hline-20 to -10 & same as recent & same as recent & 0 & 40 & 60 & 0 \\
\hline-20 to -10 & same as recent & reduced & 0 & 20 & 60 & 20 \\
\hline-20 to -10 & reduced avail & elevated & 5 & 20 & 50 & 25 \\
\hline-20 to -10 & reduced avail & same as recent & 0 & 10 & 50 & 40 \\
\hline-20 to -10 & reduced avail & reduced & 0 & 0 & 40 & 60 \\
\hline-20 to -10 & greatly reduced avail & elevated & 0 & 10 & 50 & 40 \\
\hline-20 to -10 & greatly reduced avail & same as recent & 0 & 0 & 30 & 70 \\
\hline-20 to -10 & greatly reduced avail & reduced & 0 & 0 & 10 & 90 \\
\hline-40 to -20 & improved availability & elevated & 20 & 60 & 20 & 0 \\
\hline
\end{tabular}




\begin{tabular}{|l|l|l|c|c|c|c|}
\hline $\begin{array}{c}\text { Foraging } \\
\text { Sea Ice Area }\end{array}$ & \multicolumn{1}{|c|}{$\begin{array}{c}\text { Foraging Sea Ice } \\
\text { Distribution }\end{array}$} & $\begin{array}{c}\text { Foraging Sea Ice } \\
\text { Quality }\end{array}$ & Improved & $\begin{array}{c}\text { Same as } \\
\text { Base }\end{array}$ & Reduced & $\begin{array}{c}\text { Greatly } \\
\text { Reduced }\end{array}$ \\
\hline-40 to -20 & improved availability & same as recent & 10 & 60 & 30 & 0 \\
\hline-40 to -20 & improved availability & reduced & 5 & 30 & 45 & 20 \\
\hline-40 to -20 & same as recent & elevated & 10 & 40 & 40 & 10 \\
\hline-40 to -20 & same as recent & same as recent & 0 & 20 & 50 & 30 \\
\hline-40 to -20 & same as recent & reduced & 0 & 5 & 40 & 55 \\
\hline-40 to -20 & reduced avail & elevated & 0 & 10 & 60 & 30 \\
\hline-40 to -20 & reduced avail & same as recent & 0 & 5 & 50 & 45 \\
\hline-40 to -20 & reduced avail & reduced & 0 & 0 & 40 & 60 \\
\hline-40 to -20 & greatly reduced avail & elevated & 0 & 0 & 30 & 70 \\
\hline-40 to -20 & greatly reduced avail & same as recent & 0 & 0 & 10 & 90 \\
\hline-40 to -20 & greatly reduced avail & reduced & 0 & 0 & 0 & 100 \\
\hline$<-40$ & improved availability & elevated & 20 & 60 & 20 & 0 \\
\hline$<-40$ & improved availability & same as recent & 0 & 20 & 60 & 20 \\
\hline$<-40$ & improved availability & reduced & 0 & 0 & 50 & 50 \\
\hline$<-40$ & same as recent & elevated & 0 & 10 & 60 & 30 \\
\hline$<-40$ & same as recent & same as recent & 0 & 0 & 30 & 70 \\
\hline$<-40$ & same as recent & reduced & 0 & 0 & 20 & 80 \\
\hline$<-40$ & reduced avail & elevated & 0 & 10 & 20 & 70 \\
\hline$<-40$ & reduced avail & same as recent & 0 & 0 & 10 & 90 \\
\hline$<-40$ & reduced avail & reduced & 0 & 0 & 0 & 100 \\
\hline$<-40$ & greatly reduced avail & elevated & 0 & 0 & 0 & 100 \\
\hline$<-40$ & greatly reduced avail & same as recent & 0 & 0 & 0 & 100 \\
\hline$<-40$ & greatly reduced avail & reduced & 0 & 0 & 0 & 100 \\
\hline
\end{tabular}

E4.Foraging Sea Ice Distribution.

\begin{tabular}{|l|l|l|c|c|c|c|}
\hline \multicolumn{1}{|c|}{ Ecoregion } & $\begin{array}{c}\text { Forag. Sea } \\
\text { Ice } \mathbf{5 0 \%} \\
\text { Absence } \\
\text { Chng (mon.) }\end{array}$ & $\begin{array}{c}\text { Sea Ice Shelf } \\
\text { Distance } \\
\text { Chng (km) }\end{array}$ & Improved & $\begin{array}{c}\text { Same as } \\
\text { Base }\end{array}$ & Reduced & $\begin{array}{c}\text { Greatly } \\
\text { reduced }\end{array}$ \\
\hline Archipelago & $<0$ & $<0$ & 30 & 70 & 0 & 0 \\
\hline Archipelago & $<0$ & 0 to 200 & 30 & 70 & 0 & 0 \\
\hline Archipelago & $<0$ & 200 to 500 & 30 & 70 & 0 & 0 \\
\hline Archipelago & $<0$ & 500 to 800 & 30 & 70 & 0 & 0 \\
\hline Archipelago & $<0$ & $>=800$ & 30 & 70 & 0 & 0 \\
\hline Archipelago & 0 to 1 & $<0$ & 60 & 30 & 10 & 0 \\
\hline Archipelago & 0 to 1 & 0 to 200 & 60 & 30 & 10 & 0 \\
\hline Archipelago & 0 to 1 & 200 to 500 & 60 & 30 & 10 & 0 \\
\hline Archipelago & 0 to 1 & 500 to 800 & 60 & 30 & 10 & 0 \\
\hline Archipelago & 0 to 1 & $>=800$ & 60 & 30 & 10 & 0 \\
\hline Archipelago & 1 to 2 & $<0$ & 70 & 30 & 0 & 0 \\
\hline
\end{tabular}




\begin{tabular}{|c|c|c|c|c|c|c|}
\hline Ecoregion & $\begin{array}{l}\text { Forag. Sea } \\
\text { Ice }<50 \% \\
\text { Absence } \\
\text { Chng (mon.) }\end{array}$ & $\begin{array}{c}\text { Sea Ice Shelf } \\
\text { Distance } \\
\text { Chng (km) }\end{array}$ & Improved & $\begin{array}{c}\text { Same as } \\
\text { Base }\end{array}$ & Reduced & $\begin{array}{l}\text { Greatly } \\
\text { reduced }\end{array}$ \\
\hline Archipelago & 1 to 2 & 0 to 200 & 70 & 30 & 0 & 0 \\
\hline Archipelago & 1 to 2 & 200 to 500 & 70 & 30 & 0 & 0 \\
\hline Archipelago & 1 to 2 & 500 to 800 & 70 & 30 & 0 & 0 \\
\hline Archipelago & 1 to 2 & $>=800$ & 70 & 30 & 0 & 0 \\
\hline Archipelago & 2 to 3 & $<0$ & 50 & 30 & 20 & 0 \\
\hline Archipelago & 2 to 3 & 0 to 200 & 50 & 30 & 20 & 0 \\
\hline Archipelago & 2 to 3 & 200 to 500 & 50 & 30 & 20 & 0 \\
\hline Archipelago & 2 to 3 & 500 to 800 & 50 & 30 & 20 & 0 \\
\hline Archipelago & 2 to 3 & $>=800$ & 50 & 30 & 20 & 0 \\
\hline Archipelago & 3 to 5 & $<0$ & 30 & 50 & 20 & 0 \\
\hline Archipelago & 3 to 5 & 0 to 200 & 30 & 50 & 20 & 0 \\
\hline Archipelago & 3 to 5 & 200 to 500 & 30 & 50 & 20 & 0 \\
\hline Archipelago & 3 to 5 & 500 to 800 & 30 & 50 & 20 & 0 \\
\hline Archipelago & 3 to 5 & $>=800$ & 30 & 50 & 20 & 0 \\
\hline Archipelago & $>=5$ & $<0$ & 10 & 50 & 40 & 0 \\
\hline Archipelago & $>=5$ & 0 to 200 & 10 & 50 & 40 & 0 \\
\hline Archipelago & $>=5$ & 200 to 500 & 10 & 50 & 40 & 0 \\
\hline Archipelago & $>=5$ & 500 to 800 & 10 & 50 & 40 & 0 \\
\hline Archipelago & $>=5$ & $>=800$ & 10 & 50 & 40 & 0 \\
\hline Polar Basin Convergent & $<0$ & $<0$ & 0 & 50 & 50 & 0 \\
\hline Polar Basin Convergent & $<0$ & 0 to 200 & 0 & 40 & 60 & 0 \\
\hline Polar Basin Convergent & $<0$ & 200 to 500 & 0 & 60 & 40 & 0 \\
\hline Polar Basin Convergent & $<0$ & 500 to 800 & 0 & 70 & 30 & 0 \\
\hline Polar Basin Convergent & $<0$ & $>=800$ & 0 & 80 & 20 & 0 \\
\hline Polar Basin Convergent & 0 to 1 & $<0$ & 40 & 40 & 20 & 0 \\
\hline Polar Basin Convergent & 0 to 1 & 0 to 200 & 50 & 35 & 15 & 0 \\
\hline Polar Basin Convergent & 0 to 1 & 200 to 500 & 35 & 50 & 15 & 0 \\
\hline Polar Basin Convergent & 0 to 1 & 500 to 800 & 25 & 40 & 35 & 0 \\
\hline Polar Basin Convergent & 0 to 1 & $>=800$ & 15 & 40 & 45 & 0 \\
\hline Polar Basin Convergent & 1 to 2 & $<0$ & 40 & 40 & 20 & 0 \\
\hline Polar Basin Convergent & 1 to 2 & 0 to 200 & 30 & 50 & 20 & 0 \\
\hline Polar Basin Convergent & 1 to 2 & 200 to 500 & 20 & 50 & 30 & 0 \\
\hline Polar Basin Convergent & 1 to 2 & 500 to 800 & 10 & 40 & 50 & 0 \\
\hline Polar Basin Convergent & 1 to 2 & $>=800$ & 0 & 30 & 70 & 0 \\
\hline Polar Basin Convergent & 2 to 3 & $<0$ & 30 & 50 & 20 & 0 \\
\hline Polar Basin Convergent & 2 to 3 & 0 to 200 & 20 & 50 & 30 & 0 \\
\hline Polar Basin Convergent & 2 to 3 & 200 to 500 & 10 & 40 & 50 & 0 \\
\hline Polar Basin Convergent & 2 to 3 & 500 to 800 & 0 & 30 & 70 & 0 \\
\hline
\end{tabular}




\begin{tabular}{|c|c|c|c|c|c|c|}
\hline Ecoregion & $\begin{array}{l}\text { Forag. Sea } \\
\text { Ice }<50 \% \\
\text { Absence } \\
\text { Chng (mon.) }\end{array}$ & $\begin{array}{l}\text { Sea Ice Shelf } \\
\text { Distance } \\
\text { Chng (km) } \\
\end{array}$ & Improved & $\begin{array}{c}\text { Same as } \\
\text { Base }\end{array}$ & Reduced & $\begin{array}{c}\text { Greatly } \\
\text { reduced }\end{array}$ \\
\hline Polar Basin Convergent & 2 to 3 & $>=800$ & 0 & 20 & 80 & 0 \\
\hline Polar Basin Convergent & 3 to 5 & $<0$ & 0 & 50 & 40 & 10 \\
\hline Polar Basin Convergent & 3 to 5 & 0 to 200 & 0 & 40 & 40 & 20 \\
\hline Polar Basin Convergent & 3 to 5 & 200 to 500 & 0 & 20 & 50 & 30 \\
\hline Polar Basin Convergent & 3 to 5 & 500 to 800 & 0 & 10 & 50 & 40 \\
\hline Polar Basin Convergent & 3 to 5 & $>=800$ & 0 & 0 & 50 & 50 \\
\hline Polar Basin Convergent & $>=5$ & $<0$ & 0 & 20 & 80 & 0 \\
\hline Polar Basin Convergent & $>=5$ & 0 to 200 & 0 & 10 & 80 & 10 \\
\hline Polar Basin Convergent & $>=5$ & 200 to 500 & 0 & 0 & 75 & 25 \\
\hline Polar Basin Convergent & $>=5$ & 500 to 800 & 0 & 0 & 60 & 40 \\
\hline Polar Basin Convergent & $>=5$ & $>=800$ & 0 & 0 & 40 & 60 \\
\hline Polar Basin Divergent & $<0$ & $<0$ & 100 & 0 & 0 & 0 \\
\hline Polar Basin Divergent & $<0$ & 0 to 200 & 90 & 10 & 0 & 0 \\
\hline Polar Basin Divergent & $<0$ & 200 to 500 & 70 & 30 & 0 & 0 \\
\hline Polar Basin Divergent & $<0$ & 500 to 800 & 60 & 40 & 0 & 0 \\
\hline Polar Basin Divergent & $<0$ & $>=800$ & 50 & 50 & 0 & 0 \\
\hline Polar Basin Divergent & 0 to 1 & $<0$ & 50 & 45 & 5 & 0 \\
\hline Polar Basin Divergent & 0 to 1 & 0 to 200 & 10 & 70 & 20 & 0 \\
\hline Polar Basin Divergent & 0 to 1 & 200 to 500 & 0 & 60 & 40 & 0 \\
\hline Polar Basin Divergent & 0 to 1 & 500 to 800 & 0 & 50 & 45 & 5 \\
\hline Polar Basin Divergent & 0 to 1 & $>=800$ & 0 & 30 & 60 & 10 \\
\hline Polar Basin Divergent & 1 to 2 & $<0$ & 25 & 50 & 25 & 0 \\
\hline Polar Basin Divergent & 1 to 2 & 0 to 200 & 0 & 60 & 40 & 0 \\
\hline Polar Basin Divergent & 1 to 2 & 200 to 500 & 0 & 40 & 60 & 0 \\
\hline Polar Basin Divergent & 1 to 2 & 500 to 800 & 0 & 20 & 80 & 0 \\
\hline Polar Basin Divergent & 1 to 2 & $>=800$ & 0 & 10 & 85 & 5 \\
\hline Polar Basin Divergent & 2 to 3 & $<0$ & 10 & 50 & 40 & 0 \\
\hline Polar Basin Divergent & 2 to 3 & 0 to 200 & 0 & 10 & 80 & 10 \\
\hline Polar Basin Divergent & 2 to 3 & 200 to 500 & 0 & 0 & 85 & 15 \\
\hline Polar Basin Divergent & 2 to 3 & 500 to 800 & 0 & 0 & 70 & 30 \\
\hline Polar Basin Divergent & 2 to 3 & $>=800$ & 0 & 0 & 40 & 60 \\
\hline Polar Basin Divergent & 3 to 5 & $<0$ & 0 & 0 & 80 & 20 \\
\hline Polar Basin Divergent & 3 to 5 & 0 to 200 & 0 & 0 & 55 & 45 \\
\hline Polar Basin Divergent & 3 to 5 & 200 to 500 & 0 & 0 & 35 & 65 \\
\hline Polar Basin Divergent & 3 to 5 & 500 to 800 & 0 & 0 & 20 & 80 \\
\hline Polar Basin Divergent & 3 to 5 & $>=800$ & 0 & 0 & 0 & 100 \\
\hline Polar Basin Divergent & $>=5$ & $<0$ & 0 & 0 & 30 & 70 \\
\hline Polar Basin Divergent & $>=5$ & 0 to 200 & 0 & 0 & 20 & 80 \\
\hline
\end{tabular}




\begin{tabular}{|c|c|c|c|c|c|c|}
\hline Ecoregion & $\begin{array}{c}\text { Forag. Sea } \\
\text { Ice <50\% } \\
\text { Absence } \\
\text { Chng (mon.) }\end{array}$ & $\begin{array}{c}\text { Sea Ice Shelf } \\
\text { Distance } \\
\text { Chng (km) } \\
\end{array}$ & Improved & $\begin{array}{c}\text { Same as } \\
\text { Base }\end{array}$ & Reduced & $\begin{array}{c}\text { Greatly } \\
\text { reduced }\end{array}$ \\
\hline Polar Basin Divergent & $>=5$ & 200 to 500 & 0 & 0 & 10 & 90 \\
\hline Polar Basin Divergent & $>=5$ & 500 to 800 & 0 & 0 & 0 & 100 \\
\hline Polar Basin Divergent & $>=5$ & $>=800$ & 0 & 0 & 0 & 100 \\
\hline Seasonal Ice & $<0$ & $<0$ & 100 & 0 & 0 & 0 \\
\hline Seasonal Ice & $<0$ & 0 to 200 & 100 & 0 & 0 & 0 \\
\hline Seasonal Ice & $<0$ & 200 to 500 & 100 & 0 & 0 & 0 \\
\hline Seasonal Ice & $<0$ & 500 to 800 & 100 & 0 & 0 & 0 \\
\hline Seasonal Ice & $<0$ & $>=800$ & 100 & 0 & 0 & 0 \\
\hline Seasonal Ice & 0 to 1 & $<0$ & 0 & 50 & 50 & 0 \\
\hline Seasonal Ice & 0 to 1 & 0 to 200 & 0 & 50 & 50 & 0 \\
\hline Seasonal Ice & 0 to 1 & 200 to 500 & 0 & 50 & 50 & 0 \\
\hline Seasonal Ice & 0 to 1 & 500 to 800 & 0 & 50 & 50 & 0 \\
\hline Seasonal Ice & 0 to 1 & $>=800$ & 0 & 50 & 50 & 0 \\
\hline Seasonal Ice & 1 to 2 & $<0$ & 0 & 20 & 80 & 0 \\
\hline Seasonal Ice & 1 to 2 & 0 to 200 & 0 & 20 & 80 & 0 \\
\hline Seasonal Ice & 1 to 2 & 200 to 500 & 0 & 20 & 80 & 0 \\
\hline Seasonal Ice & 1 to 2 & 500 to 800 & 0 & 20 & 80 & 0 \\
\hline Seasonal Ice & 1 to 2 & $>=800$ & 0 & 20 & 80 & 0 \\
\hline Seasonal Ice & 2 to 3 & $<0$ & 0 & 0 & 80 & 20 \\
\hline Seasonal Ice & 2 to 3 & 0 to 200 & 0 & 0 & 80 & 20 \\
\hline Seasonal Ice & 2 to 3 & 200 to 500 & 0 & 0 & 80 & 20 \\
\hline Seasonal Ice & 2 to 3 & 500 to 800 & 0 & 0 & 80 & 20 \\
\hline Seasonal Ice & 2 to 3 & $>=800$ & 0 & 0 & 80 & 20 \\
\hline Seasonal Ice & 3 to 5 & $<0$ & 0 & 0 & 10 & 90 \\
\hline Seasonal Ice & 3 to 5 & 0 to 200 & 0 & 0 & 10 & 90 \\
\hline Seasonal Ice & 3 to 5 & 200 to 500 & 0 & 0 & 10 & 90 \\
\hline Seasonal Ice & 3 to 5 & 500 to 800 & 0 & 0 & 10 & 90 \\
\hline Seasonal Ice & 3 to 5 & $>=800$ & 0 & 0 & 10 & 90 \\
\hline Seasonal Ice & $>=5$ & $<0$ & 0 & 0 & 0 & 100 \\
\hline Seasonal Ice & $>=5$ & 0 to 200 & 0 & 0 & 0 & 100 \\
\hline Seasonal Ice & $>=5$ & 200 to 500 & 0 & 0 & 0 & 100 \\
\hline Seasonal Ice & $>=5$ & 500 to 800 & 0 & 0 & 0 & 100 \\
\hline Seasonal Ice & $>=5$ & $>=800$ & 0 & 0 & 0 & 100 \\
\hline
\end{tabular}


E5. Overall Terrestrial Prey/Food Abundance.

\begin{tabular}{|l|l|c|c|c|c|}
\hline $\begin{array}{c}\text { Terr. \& Marine } \\
\text { Prey/Food Access }\end{array}$ & $\begin{array}{c}\text { Human Provisioned } \\
\text { Food Abund. }\end{array}$ & Elevated & Same as Recent & Reduced & Absent \\
\hline elevated & elevated & 100 & 0 & 0 & 0 \\
\hline elevated & same as recent & 95 & 5 & 0 & 0 \\
\hline elevated & reduced & 85 & 10 & 5 & 0 \\
\hline elevated & absent & 75 & 15 & 10 & 0 \\
\hline same as recent & elevated & 5 & 95 & 0 & 0 \\
\hline same as recent & same as recent & 0 & 100 & 0 & 0 \\
\hline same as recent & reduced & 0 & 95 & 5 & 0 \\
\hline same as recent & absent & 0 & 90 & 10 & 0 \\
\hline reduced & elevated & 0 & 10 & 90 & 0 \\
\hline reduced & same as recent & 0 & 5 & 95 & 0 \\
\hline reduced & reduced & 0 & 0 & 100 & 0 \\
\hline reduced & absent & 0 & 0 & 95 & 5 \\
\hline absent & elevated & 0 & 10 & 15 & 75 \\
\hline absent & same as recent & 0 & 5 & 20 & 75 \\
\hline absent & reduced & 0 & 0 & 0 & 100 \\
\hline absent & absent & 0 & 0 & 0 & 100 \\
\hline
\end{tabular}


E6. Bears on Shore.

\begin{tabular}{|c|c|c|c|c|c|c|}
\hline $\begin{array}{l}\text { Overall Sea Ice } \\
\text { Conditions }\end{array}$ & Ecoregion & $\begin{array}{c}\text { Overall Terrestrial } \\
\text { Prey/Food } \\
\text { Availability }\end{array}$ & $\begin{array}{c}\text { Greatly } \\
\text { Increased }\end{array}$ & Increased & $\begin{array}{c}\text { Same as } \\
\text { Recent }\end{array}$ & $\begin{array}{c}\text { Less than } \\
\text { Recent }\end{array}$ \\
\hline improved & Archipelago & elevated & 0 & 0 & 20 & 80 \\
\hline improved & Archipelago & same as recent & 0 & 0 & 15 & 85 \\
\hline improved & Archipelago & reduced & 0 & 0 & 5 & 95 \\
\hline improved & Archipelago & absent & 0 & 0 & 0 & 100 \\
\hline improved & Polar Basin Convergent & elevated & 0 & 5 & 25 & 70 \\
\hline improved & Polar Basin Convergent & same as recent & 0 & 0 & 30 & 70 \\
\hline improved & Polar Basin Convergent & reduced & 0 & 0 & 20 & 80 \\
\hline improved & Polar Basin Convergent & absent & 0 & 0 & 10 & 90 \\
\hline improved & Polar Basin Divergent & elevated & 0 & 5 & 25 & 70 \\
\hline improved & Polar Basin Divergent & same as recent & 0 & 0 & 30 & 70 \\
\hline improved & Polar Basin Divergent & reduced & 0 & 0 & 20 & 80 \\
\hline improved & Polar Basin Divergent & absent & 0 & 0 & 10 & 90 \\
\hline improved & Seasonal Ice & elevated & 0 & 0 & 0 & 100 \\
\hline improved & Seasonal Ice & same as recent & 0 & 0 & 0 & 100 \\
\hline improved & Seasonal Ice & reduced & 0 & 0 & 0 & 100 \\
\hline improved & Seasonal Ice & absent & 0 & 0 & 0 & 100 \\
\hline same as recent & Archipelago & elevated & 0 & 15 & 80 & 5 \\
\hline same as recent & Archipelago & same as recent & 0 & 10 & 80 & 10 \\
\hline same as recent & Archipelago & reduced & 0 & 10 & 75 & 15 \\
\hline same as recent & Archipelago & absent & 0 & 5 & 70 & 25 \\
\hline same as recent & Polar Basin Convergent & elevated & 0 & 20 & 80 & 0 \\
\hline same as recent & Polar Basin Convergent & same as recent & 0 & 0 & 100 & 0 \\
\hline same as recent & Polar Basin Convergent & reduced & 0 & 0 & 40 & 60 \\
\hline same as recent & Polar Basin Convergent & absent & 0 & 0 & 20 & 80 \\
\hline same as recent & Polar Basin Divergent & elevated & 0 & 20 & 80 & 0 \\
\hline
\end{tabular}




\begin{tabular}{|c|c|c|c|c|c|c|}
\hline $\begin{array}{l}\text { Overall Sea Ice } \\
\text { Conditions }\end{array}$ & Ecoregion & $\begin{array}{c}\text { Overall Terrestrial } \\
\text { Prey/Food } \\
\text { Availability }\end{array}$ & $\begin{array}{c}\text { Greatly } \\
\text { Increased }\end{array}$ & Increased & $\begin{array}{c}\text { Same as } \\
\text { Recent }\end{array}$ & $\begin{array}{l}\text { Less than } \\
\text { Recent }\end{array}$ \\
\hline same as recent & Polar Basin Divergent & same as recent & 0 & 0 & 100 & 0 \\
\hline same as recent & Polar Basin Divergent & reduced & 0 & 0 & 40 & 60 \\
\hline same as recent & Polar Basin Divergent & absent & 0 & 0 & 20 & 80 \\
\hline same as recent & Seasonal Ice & elevated & 0 & 5 & 90 & 5 \\
\hline same as recent & Seasonal Ice & same as recent & 0 & 5 & 90 & 5 \\
\hline same as recent & Seasonal Ice & reduced & 0 & 5 & 90 & 5 \\
\hline same as recent & Seasonal Ice & absent & 0 & 5 & 90 & 5 \\
\hline reduced & Archipelago & elevated & 10 & 40 & 50 & 0 \\
\hline reduced & Archipelago & same as recent & 5 & 45 & 50 & 0 \\
\hline reduced & Archipelago & reduced & 5 & 50 & 45 & 0 \\
\hline reduced & Archipelago & absent & 5 & 55 & 40 & 0 \\
\hline reduced & Polar Basin Convergent & elevated & 30 & 60 & 10 & 0 \\
\hline reduced & Polar Basin Convergent & same as recent & 0 & 80 & 20 & 0 \\
\hline reduced & Polar Basin Convergent & reduced & 0 & 50 & 30 & 20 \\
\hline reduced & Polar Basin Convergent & absent & 0 & 40 & 30 & 30 \\
\hline reduced & Polar Basin Divergent & elevated & 30 & 60 & 10 & 0 \\
\hline reduced & Polar Basin Divergent & same as recent & 0 & 80 & 20 & 0 \\
\hline reduced & Polar Basin Divergent & reduced & 0 & 50 & 30 & 20 \\
\hline reduced & Polar Basin Divergent & absent & 0 & 40 & 30 & 30 \\
\hline reduced & Seasonal Ice & elevated & 5 & 90 & 5 & 0 \\
\hline reduced & Seasonal Ice & same as recent & 5 & 90 & 5 & 0 \\
\hline reduced & Seasonal Ice & reduced & 5 & 90 & 5 & 0 \\
\hline reduced & Seasonal Ice & absent & 5 & 90 & 5 & 0 \\
\hline greatly reduced & Archipelago & elevated & 55 & 45 & 0 & 0 \\
\hline greatly reduced & Archipelago & same as recent & 50 & 45 & 5 & 0 \\
\hline greatly reduced & Archipelago & reduced & 45 & 50 & 5 & 0 \\
\hline greatly reduced & Archipelago & absent & 40 & 55 & 5 & 0 \\
\hline greatly reduced & Polar Basin Convergent & elevated & 90 & 10 & 0 & 0 \\
\hline
\end{tabular}




\begin{tabular}{|l|l|l|c|c|c|c|}
\hline $\begin{array}{c}\text { Overall Sea Ice } \\
\text { Conditions }\end{array}$ & \multicolumn{1}{|c|}{ Ecoregion } & $\begin{array}{c}\text { Overall Terrestrial } \\
\text { Prey/Food } \\
\text { Availability }\end{array}$ & $\begin{array}{c}\text { Greatly } \\
\text { Increased }\end{array}$ & Increased & $\begin{array}{c}\text { Same as } \\
\text { Recent }\end{array}$ & $\begin{array}{c}\text { Less than } \\
\text { Recent }\end{array}$ \\
\hline greatly reduced & Polar Basin Convergent & same as recent & 80 & 20 & 0 & 0 \\
\hline greatly reduced & Polar Basin Convergent & reduced & 70 & 30 & 0 & 0 \\
\hline greatly reduced & Polar Basin Convergent & absent & 60 & 40 & 0 & 0 \\
\hline greatly reduced & Polar Basin Divergent & elevated & 90 & 10 & 0 & 0 \\
\hline greatly reduced & Polar Basin Divergent & same as recent & 80 & 20 & 0 & 0 \\
\hline greatly reduced & Polar Basin Divergent & reduced & 70 & 30 & 0 & 0 \\
\hline greatly reduced & Polar Basin Divergent & absent & 60 & 40 & 0 & 0 \\
\hline greatly reduced & Seasonal Ice & elevated & 95 & 5 & 0 & 0 \\
\hline greatly reduced & Seasonal Ice & same as recent & 95 & 5 & 0 & 0 \\
\hline greatly reduced & Seasonal Ice & reduced & 95 & 5 & 0 & 0 \\
\hline greatly reduced & Seasonal Ice & absent & 95 & 5 & 0 & 0 \\
\hline
\end{tabular}


E7. Overall Marine Conditions.

\begin{tabular}{|l|l|c|c|c|}
\hline \multicolumn{1}{|c|}{$\begin{array}{c}\text { Overall Sea Ice } \\
\text { Conditions }\end{array}$} & \multicolumn{1}{|c|}{ Marine Prey Base Quality } & Improved & Same as Recent & Degraded \\
\hline improved availability & elevated & 100 & 0 & 0 \\
\hline improved availability & same as recent & 60 & 40 & 0 \\
\hline improved availability & reduced & 10 & 30 & 60 \\
\hline same as recent & elevated & 70 & 30 & 0 \\
\hline same as recent & same as recent & 0 & 100 & 0 \\
\hline same as recent & reduced & 0 & 40 & 60 \\
\hline reduced avail & elevated & 10 & 40 & 50 \\
\hline reduced avail & same as recent & 0 & 40 & 60 \\
\hline reduced avail & reduced & 0 & 30 & 70 \\
\hline greatly reduced avail & elevated & 5 & 30 & 65 \\
\hline greatly reduced avail & same as recent & 0 & 10 & 90 \\
\hline greatly reduced avail & reduced & 0 & 100 \\
\hline
\end{tabular}

\section{E8. Overall Terrestrial Conditions.}

\begin{tabular}{|l|l|c|c|c|}
\hline \multicolumn{1}{|c|}{ Bears on Shore } & \multicolumn{1}{c|}{$\begin{array}{c}\text { Terrestrial Refugia } \\
\text { Quality }\end{array}$} & Improved & Same as Base & Degraded \\
\hline greatly increased & improved & 10 & 50 & 40 \\
\hline greatly increased & not degraded & 0 & 40 & 60 \\
\hline greatly increased & degraded & 0 & 5 & 95 \\
\hline increased & improved & 15 & 70 & 15 \\
\hline increased & not degraded & 0 & 50 & 50 \\
\hline increased & degraded & 0 & 25 & 75 \\
\hline same as recent & improved & 40 & 60 & 0 \\
\hline same as recent & not degraded & 0 & 100 & 0 \\
\hline same as recent & degraded & 0 & 60 & 40 \\
\hline less than recent & improved & 100 & 0 & 0 \\
\hline less than recent & not degraded & 75 & 25 & 0 \\
\hline less than recent & degraded & 25 & 50 & 25 \\
\hline
\end{tabular}


E9. Overall Habitat Suitability.

\begin{tabular}{|l|l|c|c|c|c|}
\hline $\begin{array}{c}\text { Overall Marine } \\
\text { Conditions }\end{array}$ & \multicolumn{1}{|c|}{$\begin{array}{c}\text { Overall Terrestrial } \\
\text { Conditions }\end{array}$} & Elevated & $\begin{array}{c}\text { Same as } \\
\text { Base }\end{array}$ & Reduced & $\begin{array}{c}\text { Greatly } \\
\text { Reduced }\end{array}$ \\
\hline improved & improved & 100 & 0 & 0 & 0 \\
\hline improved & same as recent & 95 & 5 & 0 & 0 \\
\hline improved & degraded & 90 & 5 & 5 & 0 \\
\hline same as recent & improved & 20 & 80 & 0 & 0 \\
\hline same as recent & same as recent & 0 & 100 & 0 & 0 \\
\hline same as recent & degraded & 0 & 60 & 40 & 0 \\
\hline degraded & improved & 0 & 0 & 100 & 0 \\
\hline degraded & same as recent & 0 & 0 & 80 & 20 \\
\hline degraded & degraded & 0 & 0 & 0 & 100 \\
\hline
\end{tabular}

E10. Event-Driven Mortality.

\begin{tabular}{|l|l|l|c|c|c|}
\hline $\begin{array}{c}\text { Human-Bear DLP } \\
\text { Lethal } \\
\text { Interactions }\end{array}$ & \multicolumn{1}{|c|}{$\begin{array}{c}\text { Hunting Mortality } \\
\text { (legal) }\end{array}$} & $\begin{array}{c}\text { Other Mortality or } \\
\text { Removal Events }\end{array}$ & Elevated & $\begin{array}{c}\text { Same as } \\
\text { Recent }\end{array}$ & Reduced \\
\hline elevated & elevated & elevated & 100 & 0 & 0 \\
\hline elevated & elevated & same as recent & 95 & 5 & 0 \\
\hline elevated & elevated & reduced & 90 & 5 & 5 \\
\hline elevated & same as recent & elevated & 30 & 70 & 0 \\
\hline elevated & same as recent & same as recent & 20 & 80 & 0 \\
\hline elevated & same as recent & reduced & 10 & 80 & 10 \\
\hline elevated & reduced & elevated & 10 & 40 & 50 \\
\hline elevated & reduced & same as recent & 5 & 30 & 65 \\
\hline elevated & reduced & reduced & 5 & 10 & 85 \\
\hline same as recent & elevated & elevated & 90 & 10 & 0 \\
\hline same as recent & elevated & same as recent & 80 & 20 & 0 \\
\hline same as recent & elevated & reduced & 60 & 30 & 10 \\
\hline same as recent & same as recent & elevated & 5 & 95 & 0 \\
\hline same as recent & same as recent & same as recent & 0 & 100 & 0 \\
\hline same as recent & same as recent & reduced & 0 & 90 & 10 \\
\hline same as recent & reduced & elevated & 5 & 20 & 75 \\
\hline same as recent & reduced & same as recent & 0 & 15 & 85 \\
\hline same as recent & reduced & reduced & 0 & 10 & 90 \\
\hline reduced & elevated & elevated & 70 & 25 & 5 \\
\hline reduced & elevated & same as recent & 60 & 30 & 10 \\
\hline reduced & elevated & reduced & 50 & 30 & 20 \\
\hline reduced & same as recent & elevated & 5 & 65 & 30 \\
\hline reduced & same as recent & same as recent & 0 & 85 & 15 \\
\hline reduced & same as recent & reduced & 0 & 75 & 25 \\
\hline
\end{tabular}




\begin{tabular}{|l|l|l|c|c|c|}
\hline $\begin{array}{c}\text { Human-Bear DLP } \\
\text { Lethal } \\
\text { Interactions }\end{array}$ & $\begin{array}{c}\text { Hunting Mortality } \\
\text { (legal) }\end{array}$ & $\begin{array}{c}\text { Other Mortality or } \\
\text { Removal Events }\end{array}$ & Elevated & $\begin{array}{c}\text { Same as } \\
\text { Recent }\end{array}$ & Reduced \\
\hline reduced & reduced & elevated & 0 & 10 & 90 \\
\hline reduced & reduced & same as recent & 0 & 5 & 95 \\
\hline reduced & reduced & reduced & 0 & 0 & 100 \\
\hline
\end{tabular}

\section{E11. Other Mortality or Removal Events.}

\begin{tabular}{|l|l|l|c|c|c|}
\hline \multicolumn{1}{|c|}{ Oil Spills, Small } & Oil Spills, Large & \multicolumn{1}{c|}{ Other Events } & Elevated & $\begin{array}{c}\text { Same as } \\
\text { Base }\end{array}$ & Reduced \\
\hline elevated & elevated & elevated & 100 & 0 & 0 \\
\hline elevated & elevated & same as recent & 100 & 0 & 0 \\
\hline elevated & elevated & reduced & 80 & 20 & 0 \\
\hline elevated & same as recent & elevated & 70 & 30 & 0 \\
\hline elevated & same as recent & same as recent & 60 & 40 & 0 \\
\hline elevated & same as recent & reduced & 40 & 50 & 10 \\
\hline elevated & reduced & elevated & 60 & 30 & 10 \\
\hline elevated & reduced & same as recent & 50 & 40 & 10 \\
\hline elevated & reduced & reduced & 30 & 30 & 40 \\
\hline same as recent & elevated & elevated & 70 & 30 & 0 \\
\hline same as base & elevated & same as recent & 60 & 40 & 0 \\
\hline same as recent & elevated & reduced & 40 & 50 & 10 \\
\hline same as recent & same as recent & elevated & 40 & 60 & 0 \\
\hline same as recent & same as recent & same as recent & 0 & 100 & 0 \\
\hline same as recent & same as recent & reduced & 0 & 80 & 20 \\
\hline same as recent & reduced & elevated & 10 & 80 & 10 \\
\hline same as recent & reduced & same as recent & 0 & 70 & 30 \\
\hline same as recent & reduced & reduced & 0 & 40 & 60 \\
\hline reduced & elevated & elevated & 70 & 30 & 0 \\
\hline reduced & elevated & same as recent & 50 & 25 & 25 \\
\hline reduced & sevated & reduced & 30 & 20 & 50 \\
\hline reduced & same as recent & elevated & 10 & 80 & 10 \\
\hline reduced & reduced & elevated & 0 & 60 & 40 \\
\hline reduced & same as recent & 0 & 10 & 80 \\
\hline reduced & reduced & 0 & 0 & 100 \\
\hline reduced & & 0 & 20 & 70 \\
\hline reduced & reduced & 30 & 90 \\
\hline
\end{tabular}


E12. Adult Survival.

\begin{tabular}{|c|c|c|c|c|c|}
\hline $\begin{array}{l}\text { Event-driven } \\
\text { Mortality }\end{array}$ & $\begin{array}{c}\text { Overall Habitat } \\
\text { Suitability }\end{array}$ & $\begin{array}{l}\text { Parasites and } \\
\text { Disease }\end{array}$ & Increased & $\begin{array}{l}\text { Same as } \\
\text { Base }\end{array}$ & Decreased \\
\hline elevated & elevated & elevated & 75 & 15 & 10 \\
\hline elevated & elevated & same as recent & 80 & 20 & 0 \\
\hline elevated & elevated & reduced & 90 & 10 & 0 \\
\hline elevated & same as recent & elevated & 0 & 40 & 60 \\
\hline elevated & same as recent & same as recent & 0 & 60 & 40 \\
\hline elevated & same as recent & reduced & 10 & 60 & 30 \\
\hline elevated & reduced & elevated & 0 & 0 & 100 \\
\hline elevated & reduced & same as recent & 0 & 10 & 90 \\
\hline elevated & reduced & reduced & 0 & 15 & 85 \\
\hline elevated & greatly reduced & elevated & 0 & 0 & 100 \\
\hline elevated & greatly reduced & same as recent & 0 & 0 & 100 \\
\hline elevated & greatly reduced & reduced & 0 & 0 & 100 \\
\hline same as recent & elevated & elevated & 80 & 20 & 0 \\
\hline same as recent & elevated & same as recent & 90 & 10 & 0 \\
\hline same as recent & elevated & reduced & 100 & 0 & 0 \\
\hline same as recent & same as recent & elevated & 0 & 60 & 40 \\
\hline same as recent & same as recent & same as recent & 0 & 100 & 0 \\
\hline same as recent & same as recent & reduced & 30 & 70 & 0 \\
\hline same as recent & reduced & elevated & 0 & 10 & 90 \\
\hline same as recent & reduced & same as recent & 0 & 20 & 80 \\
\hline same as recent & reduced & reduced & 0 & 25 & 75 \\
\hline same as recent & greatly reduced & elevated & 0 & 0 & 100 \\
\hline same as recent & greatly reduced & same as recent & 0 & 0 & 100 \\
\hline same as recent & greatly reduced & reduced & 0 & 0 & 100 \\
\hline reduced & elevated & elevated & 90 & 10 & 0 \\
\hline reduced & elevated & same as recent & 100 & 0 & 0 \\
\hline reduced & elevated & reduced & 100 & 0 & 0 \\
\hline reduced & same as recent & elevated & 10 & 60 & 30 \\
\hline reduced & same as recent & same as recent & 30 & 70 & 0 \\
\hline reduced & same as recent & reduced & 40 & 60 & 0 \\
\hline reduced & reduced & elevated & 0 & 15 & 85 \\
\hline reduced & reduced & same as recent & 0 & 25 & 75 \\
\hline reduced & reduced & reduced & 0 & 35 & 65 \\
\hline reduced & greatly reduced & elevated & 0 & 0 & 100 \\
\hline reduced & greatly reduced & same as recent & 0 & 0 & 100 \\
\hline reduced & greatly reduced & reduced & 0 & 0 & 100 \\
\hline
\end{tabular}


E13. Subadult Survival.

\begin{tabular}{|c|c|c|c|c|c|}
\hline $\begin{array}{c}\text { Event-driven } \\
\text { Mortality }\end{array}$ & $\begin{array}{l}\text { Overall Habitat } \\
\text { Suitability }\end{array}$ & $\begin{array}{l}\text { Other Biotic } \\
\text { Stressors }\end{array}$ & Increased & $\begin{array}{c}\text { Same as } \\
\text { Recent }\end{array}$ & Decreased \\
\hline elevated & elevated & elevated & 70 & 20 & 10 \\
\hline elevated & elevated & same as recent & 80 & 15 & 5 \\
\hline elevated & elevated & reduced & 90 & 10 & 0 \\
\hline elevated & same as recent & elevated & 0 & 40 & 60 \\
\hline elevated & same as recent & same as recent & 0 & 60 & 40 \\
\hline elevated & same as recent & reduced & 15 & 60 & 25 \\
\hline elevated & reduced & elevated & 0 & 0 & 100 \\
\hline elevated & reduced & same as recent & 0 & 10 & 90 \\
\hline elevated & reduced & reduced & 0 & 20 & 80 \\
\hline elevated & greatly reduced & elevated & 0 & 0 & 100 \\
\hline elevated & greatly reduced & same as recent & 0 & 0 & 100 \\
\hline elevated & greatly reduced & reduced & 0 & 0 & 100 \\
\hline same as recent & elevated & elevated & 80 & 20 & 0 \\
\hline same as recent & elevated & same as recent & 90 & 10 & 0 \\
\hline same as recent & elevated & reduced & 100 & 0 & 0 \\
\hline same as recent & same as recent & elevated & 0 & 70 & 30 \\
\hline same as recent & same as recent & same as recent & 0 & 100 & 0 \\
\hline same as recent & same as recent & reduced & 30 & 70 & 0 \\
\hline same as recent & reduced & elevated & 0 & 10 & 90 \\
\hline same as recent & reduced & same as recent & 0 & 20 & 80 \\
\hline same as recent & reduced & reduced & 0 & 25 & 75 \\
\hline same as recent & greatly reduced & elevated & 0 & 0 & 100 \\
\hline same as recent & greatly reduced & same as recent & 0 & 0 & 100 \\
\hline same as recent & greatly reduced & reduced & 0 & 0 & 100 \\
\hline reduced & elevated & elevated & 90 & 10 & 0 \\
\hline reduced & elevated & same as recent & 100 & 0 & 0 \\
\hline reduced & elevated & reduced & 100 & 0 & 0 \\
\hline reduced & same as recent & elevated & 5 & 70 & 25 \\
\hline reduced & same as recent & same as recent & 20 & 80 & 0 \\
\hline reduced & same as recent & reduced & 40 & 60 & 0 \\
\hline reduced & reduced & elevated & 0 & 15 & 85 \\
\hline reduced & reduced & same as recent & 0 & 25 & 75 \\
\hline reduced & reduced & reduced & 0 & 35 & 65 \\
\hline reduced & greatly reduced & elevated & 0 & 0 & 100 \\
\hline reduced & greatly reduced & same as recent & 0 & 0 & 100 \\
\hline reduced & greatly reduced & reduced & 0 & 0 & 100 \\
\hline
\end{tabular}




\section{E14. Adult Female Body Condition.}

\begin{tabular}{|c|c|c|c|c|c|c|}
\hline $\begin{array}{l}\text { Overall Habitat } \\
\text { Suitability }\end{array}$ & $\begin{array}{c}\text { Parasites and } \\
\text { Disease }\end{array}$ & $\begin{array}{c}\text { Anthropogenic } \\
\text { Stressors }\end{array}$ & Increased & $\begin{array}{c}\text { Same as } \\
\text { Recent }\end{array}$ & Decreased & $\begin{array}{c}\text { Greatly } \\
\text { decreased }\end{array}$ \\
\hline elevated & elevated & elevated & 60 & 20 & 15 & 5 \\
\hline elevated & elevated & same as recent & 70 & 20 & 10 & 0 \\
\hline elevated & elevated & reduced & 80 & 15 & 5 & 0 \\
\hline elevated & same as recent & elevated & 70 & 20 & 10 & 0 \\
\hline elevated & same as recent & same as recent & 95 & 5 & 0 & 0 \\
\hline elevated & same as recent & reduced & 100 & 0 & 0 & 0 \\
\hline elevated & reduced & elevated & 80 & 15 & 5 & 0 \\
\hline elevated & reduced & same as recent & 100 & 0 & 0 & 0 \\
\hline elevated & reduced & reduced & 100 & 0 & 0 & 0 \\
\hline same as recent & elevated & elevated & 0 & 80 & 20 & 0 \\
\hline same as recent & elevated & same as recent & 0 & 90 & 10 & 0 \\
\hline same as recent & elevated & reduced & 10 & 80 & 10 & 0 \\
\hline same as recent & same as recent & elevated & 0 & 90 & 10 & 0 \\
\hline same as recent & same as recent & same as recent & 0 & 100 & 0 & 0 \\
\hline same as recent & same as recent & reduced & 20 & 80 & 0 & 0 \\
\hline same as recent & reduced & elevated & 10 & 80 & 10 & 0 \\
\hline same as recent & reduced & same as recent & 20 & 80 & 0 & 0 \\
\hline same as recent & reduced & reduced & 30 & 70 & 0 & 0 \\
\hline reduced & elevated & elevated & 0 & 0 & 80 & 20 \\
\hline reduced & elevated & same as recent & 0 & 10 & 80 & 10 \\
\hline reduced & elevated & reduced & 0 & 20 & 80 & 0 \\
\hline reduced & same as recent & elevated & 0 & 10 & 80 & 10 \\
\hline reduced & same as recent & same as recent & 0 & 30 & 70 & 0 \\
\hline reduced & same as recent & reduced & 0 & 40 & 60 & 0 \\
\hline reduced & reduced & elevated & 0 & 20 & 80 & 0 \\
\hline
\end{tabular}




\begin{tabular}{|l|l|l|c|c|c|c|}
\hline $\begin{array}{c}\text { Overall Habitat } \\
\text { Suitability }\end{array}$ & $\begin{array}{c}\text { Parasites and } \\
\text { Disease }\end{array}$ & $\begin{array}{c}\text { Anthropogenic } \\
\text { Stressors }\end{array}$ & Increased & $\begin{array}{c}\text { Same as } \\
\text { Recent }\end{array}$ & Decreased & $\begin{array}{c}\text { Greatly } \\
\text { decreased }\end{array}$ \\
\hline reduced & reduced & same as recent & 0 & 40 & 60 & 0 \\
\hline reduced & reduced & reduced & 0 & 50 & 50 & 0 \\
\hline greatly reduced & elevated & elevated & 0 & 0 & 0 & 100 \\
\hline greatly reduced & elevated & same as recent & 0 & 0 & 0 & 100 \\
\hline greatly reduced & elevated & reduced & 0 & 0 & 5 & 95 \\
\hline greatly reduced & same as recent & elevated & 0 & 0 & 0 & 100 \\
\hline greatly reduced & same as recent & same as recent & 0 & 0 & 40 & 60 \\
\hline greatly reduced & same as recent & reduced & 0 & 15 & 35 & 50 \\
\hline greatly reduced & reduced & elevated & 0 & 10 & 40 & 50 \\
\hline greatly reduced & reduced & same as recent & 0 & 15 & 35 & 50 \\
\hline greatly reduced & reduced & reduced & 0 & 20 & 30 & 50 \\
\hline
\end{tabular}


E15. Terrestrial Maternal Den Access.

\begin{tabular}{|l|l|c|c|c|}
\hline \multicolumn{1}{|c|}{ Ecoregion } & $\begin{array}{c}\text { Forag. Sea Ice } \\
\text { <5\% Absence } \\
\text { Chng (mon.) }\end{array}$ & Increased & $\begin{array}{c}\text { Same as } \\
\text { Recent }\end{array}$ & Decreased \\
\hline Archipelago & $<0$ & 0 & 100 & 0 \\
\hline Archipelago & 0 to 1 & 0 & 100 & 0 \\
\hline Archipelago & 1 to 2 & 0 & 100 & 0 \\
\hline Archipelago & 2 to 3 & 0 & 100 & 0 \\
\hline Archipelago & 3 to 5 & 0 & 100 & 0 \\
\hline Archipelago & $>=5$ & 0 & 100 & 0 \\
\hline Polar Basin Convergent & $<0$ & 0 & 100 & 0 \\
\hline Polar Basin Convergent & 0 to 1 & 0 & 100 & 0 \\
\hline Polar Basin Convergent & 1 to 2 & 0 & 100 & 0 \\
\hline Polar Basin Convergent & 2 to 3 & 0 & 100 & 0 \\
\hline Polar Basin Convergent & 3 to 5 & 0 & 100 & 0 \\
\hline Polar Basin Convergent & $>=5$ & 0 & 100 & 0 \\
\hline Polar Basin Divergent & $<0$ & 70 & 30 & 0 \\
\hline Polar Basin Divergent & 0 to 1 & 50 & 50 & 0 \\
\hline Polar Basin Divergent & 1 to 2 & 0 & 60 & 40 \\
\hline Polar Basin Divergent & 2 to 3 & 0 & 40 & 60 \\
\hline Polar Basin Divergent & 3 to 5 & 0 & 30 & 70 \\
\hline Polar Basin Divergent & $>=5$ & 0 & 0 & 100 \\
\hline Seasonal Ice & $<0$ & 0 & 100 & 0 \\
\hline Seasonal Ice & 0 to 1 & 0 & 100 & 0 \\
\hline Seasonal Ice & 1 to 2 & 100 & 0 \\
\hline Seasonal Ice & 2 to 3 & 100 & 0 \\
\hline Seasonal Ice & 3 to 5 & 0 & 100 & 0 \\
\hline Seasonal Ice & $>=5$ & 0 & 0 \\
\hline & & 0 & 0 & 0 \\
\hline
\end{tabular}


E16. Sub-lethal Human Disturbance.

\begin{tabular}{|c|c|c|c|c|c|c|}
\hline Shipping & $\begin{array}{l}\text { Human-Bear } \\
\text { Sub-Lethal } \\
\text { Interactions }\end{array}$ & $\begin{array}{c}\text { Oil, Gas, \& } \\
\text { Mining Activity }\end{array}$ & Tourism & Reduced & $\begin{array}{c}\text { Same as } \\
\text { Base }\end{array}$ & Elevated \\
\hline elevated & elevated & elevated & elevated & 0 & 0 & 100 \\
\hline elevated & elevated & elevated & same as recent & 0 & 25 & 75 \\
\hline elevated & elevated & elevated & reduced & 5 & 25 & 70 \\
\hline elevated & elevated & same as recent & elevated & 0 & 25 & 75 \\
\hline elevated & elevated & same as recent & same as recent & 0 & 50 & 50 \\
\hline elevated & elevated & same as recent & reduced & 25 & 25 & 50 \\
\hline elevated & elevated & reduced & elevated & 5 & 25 & 70 \\
\hline elevated & elevated & reduced & same as recent & 25 & 25 & 50 \\
\hline elevated & elevated & reduced & reduced & 33 & 33 & 33 \\
\hline elevated & same as recent & elevated & elevated & 0 & 25 & 75 \\
\hline elevated & same as recent & elevated & same as recent & 0 & 50 & 50 \\
\hline elevated & same as recent & elevated & reduced & 25 & 25 & 50 \\
\hline elevated & same as recent & same as recent & elevated & 0 & 50 & 50 \\
\hline elevated & same as recent & same as recent & same as recent & 0 & 75 & 25 \\
\hline elevated & same as recent & same as recent & reduced & 25 & 50 & 25 \\
\hline elevated & same as recent & reduced & elevated & 25 & 25 & 50 \\
\hline elevated & same as recent & reduced & same as recent & 25 & 50 & 25 \\
\hline elevated & same as recent & reduced & reduced & 50 & 25 & 25 \\
\hline elevated & reduced & elevated & elevated & 5 & 25 & 70 \\
\hline elevated & reduced & elevated & same as recent & 25 & 25 & 50 \\
\hline elevated & reduced & elevated & reduced & 33 & 33 & 33 \\
\hline elevated & reduced & same as recent & elevated & 25 & 25 & 50 \\
\hline elevated & reduced & same as recent & same as recent & 25 & 50 & 25 \\
\hline elevated & reduced & same as recent & reduced & 50 & 25 & 25 \\
\hline elevated & reduced & reduced & elevated & 33 & 33 & 33 \\
\hline elevated & reduced & reduced & same as recent & 50 & 25 & 25 \\
\hline elevated & reduced & reduced & reduced & 70 & 25 & 5 \\
\hline same as recent & elevated & elevated & elevated & 0 & 25 & 75 \\
\hline same as recent & elevated & elevated & same as recent & 0 & 50 & 50 \\
\hline same as recent & elevated & elevated & reduced & 25 & 25 & 50 \\
\hline same as recent & elevated & same as recent & elevated & 0 & 50 & 50 \\
\hline same as recent & elevated & same as recent & same as recent & 0 & 75 & 25 \\
\hline same as recent & elevated & same as recent & reduced & 25 & 50 & 25 \\
\hline same as recent & elevated & reduced & elevated & 25 & 25 & 50 \\
\hline same as recent & elevated & reduced & same as recent & 25 & 50 & 25 \\
\hline same as recent & elevated & reduced & reduced & 50 & 25 & 25 \\
\hline same as recent & same as recent & elevated & elevated & 0 & 50 & 50 \\
\hline
\end{tabular}




\begin{tabular}{|c|c|c|c|c|c|c|}
\hline Shipping & $\begin{array}{l}\text { Human-Bear } \\
\text { Sub-Lethal } \\
\text { Interactions }\end{array}$ & $\begin{array}{c}\text { Oil, Gas, \& } \\
\text { Mining Activity }\end{array}$ & Tourism & Reduced & $\begin{array}{c}\text { Same as } \\
\text { Base }\end{array}$ & Elevated \\
\hline same as recent & same as recent & elevated & same as recent & 0 & 75 & 25 \\
\hline same as recent & same as recent & elevated & reduced & 25 & 50 & 25 \\
\hline same as recent & same as recent & same as recent & elevated & 0 & 75 & 25 \\
\hline same as recent & same as recent & same as recent & same as recent & 0 & 100 & 0 \\
\hline same as recent & same as recent & same as recent & reduced & 25 & 75 & 0 \\
\hline same as recent & same as recent & reduced & elevated & 25 & 50 & 25 \\
\hline same as recent & same as recent & reduced & same as recent & 25 & 75 & 0 \\
\hline same as recent & same as recent & reduced & reduced & 50 & 50 & 0 \\
\hline same as recent & reduced & elevated & elevated & 25 & 25 & 50 \\
\hline same as recent & reduced & elevated & same as recent & 25 & 50 & 25 \\
\hline same as recent & reduced & elevated & reduced & 50 & 25 & 25 \\
\hline same as recent & reduced & same as recent & elevated & 25 & 50 & 25 \\
\hline same as recent & reduced & same as recent & same as recent & 25 & 75 & 0 \\
\hline same as recent & reduced & same as recent & reduced & 50 & 50 & 0 \\
\hline same as recent & reduced & reduced & elevated & 50 & 25 & 25 \\
\hline same as recent & reduced & reduced & same as recent & 50 & 50 & 0 \\
\hline same as recent & reduced & reduced & reduced & 75 & 25 & 0 \\
\hline reduced & elevated & elevated & elevated & 5 & 25 & 70 \\
\hline reduced & elevated & elevated & same as recent & 25 & 25 & 50 \\
\hline reduced & elevated & elevated & reduced & 33 & 33 & 33 \\
\hline reduced & elevated & same as recent & elevated & 25 & 25 & 50 \\
\hline reduced & elevated & same as recent & same as recent & 25 & 50 & 25 \\
\hline reduced & elevated & same as recent & reduced & 50 & 25 & 25 \\
\hline reduced & elevated & reduced & elevated & 33 & 33 & 33 \\
\hline reduced & elevated & reduced & same as recent & 50 & 25 & 25 \\
\hline reduced & elevated & reduced & reduced & 70 & 25 & 5 \\
\hline reduced & same as recent & elevated & elevated & 25 & 25 & 50 \\
\hline reduced & same as recent & elevated & same as recent & 25 & 50 & 25 \\
\hline reduced & same as recent & elevated & reduced & 50 & 25 & 25 \\
\hline reduced & same as recent & same as recent & elevated & 25 & 50 & 25 \\
\hline reduced & same as recent & same as recent & same as recent & 25 & 75 & 0 \\
\hline reduced & same as recent & same as recent & reduced & 50 & 50 & 0 \\
\hline reduced & same as recent & reduced & elevated & 50 & 25 & 25 \\
\hline reduced & same as recent & reduced & same as recent & 50 & 50 & 0 \\
\hline reduced & same as recent & reduced & reduced & 75 & 25 & 0 \\
\hline reduced & reduced & elevated & elevated & 33 & 33 & 33 \\
\hline reduced & reduced & elevated & same as recent & 50 & 25 & 25 \\
\hline reduced & reduced & elevated & reduced & 70 & 25 & 5 \\
\hline reduced & reduced & same as recent & elevated & 50 & 25 & 25 \\
\hline
\end{tabular}




\begin{tabular}{|l|l|l|l|l|c|c|}
\hline \multicolumn{1}{|c|}{ Shipping } & $\begin{array}{c}\text { Human-Bear } \\
\text { Sub-Lethal } \\
\text { Interactions }\end{array}$ & $\begin{array}{c}\text { Oil, Gas, \& } \\
\text { Mining Activity }\end{array}$ & \multicolumn{1}{|c|}{ Tourism } & Reduced & $\begin{array}{c}\text { Same as } \\
\text { Base }\end{array}$ & Elevated \\
\hline reduced & reduced & same as recent & same as recent & 50 & 50 & 0 \\
\hline reduced & reduced & same as recent & reduced & 75 & 25 & 0 \\
\hline reduced & reduced & reduced & elevated & 70 & 25 & 5 \\
\hline reduced & reduced & reduced & same as recent & 75 & 25 & 0 \\
\hline reduced & reduced & reduced & reduced & 100 & 0 & 0 \\
\hline
\end{tabular}

\section{E17. Recruitment.}

\begin{tabular}{|l|l|c|c|c|c|}
\hline \multicolumn{1}{|c|}{ Body Condition } & \multicolumn{1}{|c|}{ Den Access } & Increased & $\begin{array}{c}\text { Same as } \\
\text { Recent }\end{array}$ & $\begin{array}{c}\text { Greatly } \\
\text { Decreased } \\
\text { decreased }\end{array}$ \\
\hline increased & elevated & 100 & 0 & 0 & 0 \\
\hline increased & same as recent & 100 & 0 & 0 & 0 \\
\hline increased & reduced & 60 & 40 & 0 & 0 \\
\hline same as recent & elevated & 20 & 80 & 0 & 0 \\
\hline same as recent & same as recent & 0 & 100 & 0 & 0 \\
\hline same as recent & reduced & 0 & 80 & 20 & 0 \\
\hline decreased & elevated & 0 & 30 & 70 & 0 \\
\hline decreased & same as recent & 0 & 10 & 90 & 0 \\
\hline decreased & reduced & 0 & 0 & 50 & 50 \\
\hline greatly decreased & elevated & 0 & 0 & 0 & 100 \\
\hline greatly decreased & same as recent & 0 & 0 & 0 & 100 \\
\hline greatly decreased & reduced & 0 & 0 & 0 & 100 \\
\hline
\end{tabular}

\section{E18. Other Biotic Stressors.}

\begin{tabular}{|l|l|c|c|c|}
\hline \multicolumn{1}{|c|}{ Parasites and Disease } & \multicolumn{1}{c|}{ Predation } & Elevated & $\begin{array}{c}\text { Same as } \\
\text { Recent }\end{array}$ & Reduced \\
\hline elevated & elevated & 100 & 0 & 0 \\
\hline elevated & same as recent & 50 & 50 & 0 \\
\hline elevated & reduced & 33 & 34 & 33 \\
\hline same as recent & elevated & 50 & 50 & 0 \\
\hline same as recent & same as recent & 0 & 100 & 0 \\
\hline same as recent & reduced & 0 & 50 & 50 \\
\hline reduced & elevated & 33 & 34 & 33 \\
\hline reduced & same as recent & 0 & 50 & 50 \\
\hline reduced & reduced & 0 & 0 & 100 \\
\hline
\end{tabular}


E19. Pollution.

\begin{tabular}{|l|l|c|c|c|}
\hline \multicolumn{1}{|c|}{ Hydrocarbons/Oil Spill } & Contaminants & Reduced & $\begin{array}{c}\text { Same as } \\
\text { Recent }\end{array}$ & Elevated \\
\hline elevated & elevated & 0 & 0 & 100 \\
\hline elevated & same as recent & 0 & 50 & 50 \\
\hline elevated & reduced & 33 & 33 & 34 \\
\hline same as recent & elevated & 0 & 50 & 50 \\
\hline same as recent & same as recent & 0 & 100 & 0 \\
\hline same as recent & reduced & 50 & 50 & 0 \\
\hline reduced & elevated & 33 & 33 & 34 \\
\hline reduced & same as recent & 50 & 50 & 0 \\
\hline reduced & reduced & 100 & 0 & 0 \\
\hline
\end{tabular}

E20. Anthropogenic Stressors (sub-lethal).

\begin{tabular}{|l|l|c|c|c|}
\hline $\begin{array}{c}\text { Sub-lethal Human } \\
\text { Disturbance }\end{array}$ & \multicolumn{1}{|c|}{ Pollution (sub-lethal) } & Elevated & $\begin{array}{c}\text { Same as } \\
\text { Recent }\end{array}$ & Reduced \\
\hline reduced & reduced & 0 & 0 & 100 \\
\hline reduced & same as recent & 0 & 50 & 50 \\
\hline reduced & elevated & 33 & 33 & 34 \\
\hline same as recent & reduced & 0 & 50 & 50 \\
\hline same as recent & same as recent & 0 & 100 & 0 \\
\hline same as recent & elevated & 50 & 50 & 0 \\
\hline elevated & reduced & 33 & 33 & 34 \\
\hline elevated & same as recent & 50 & 50 & 0 \\
\hline elevated & elevated & 100 & 0 & 0 \\
\hline
\end{tabular}




\section{Appendix F. Influence Run Results for RCP 4.5 and 8.5 by Ecoregion}

Influence runs were used to examine the potential for changes in the strength of select stressors to cause measurable changes in relative population trend, and to rank stressors in order of importance to population outcomes.
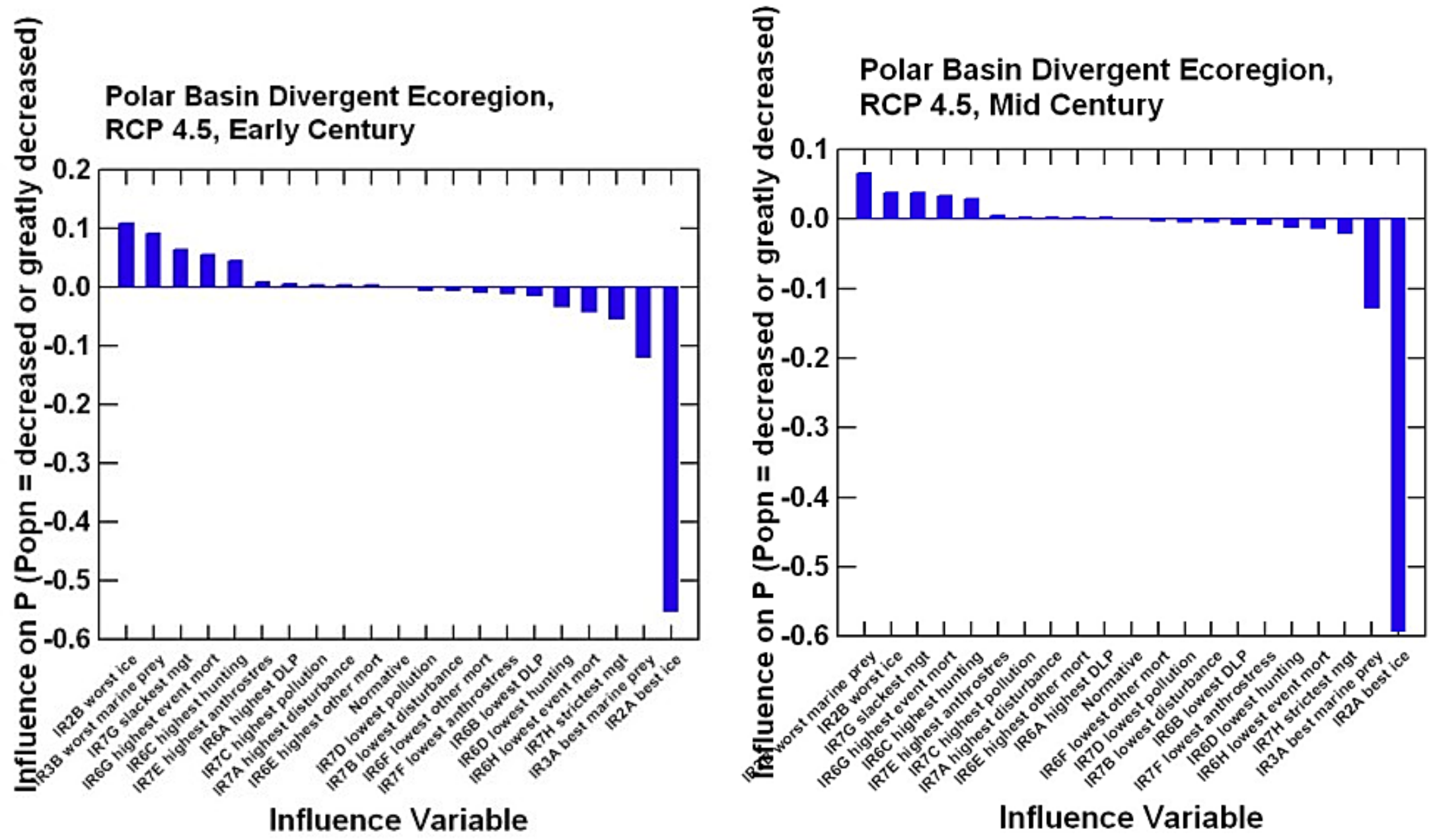

Figure F.1a. Polar Basin Divergent Ecoregion, RCP 4.5. 

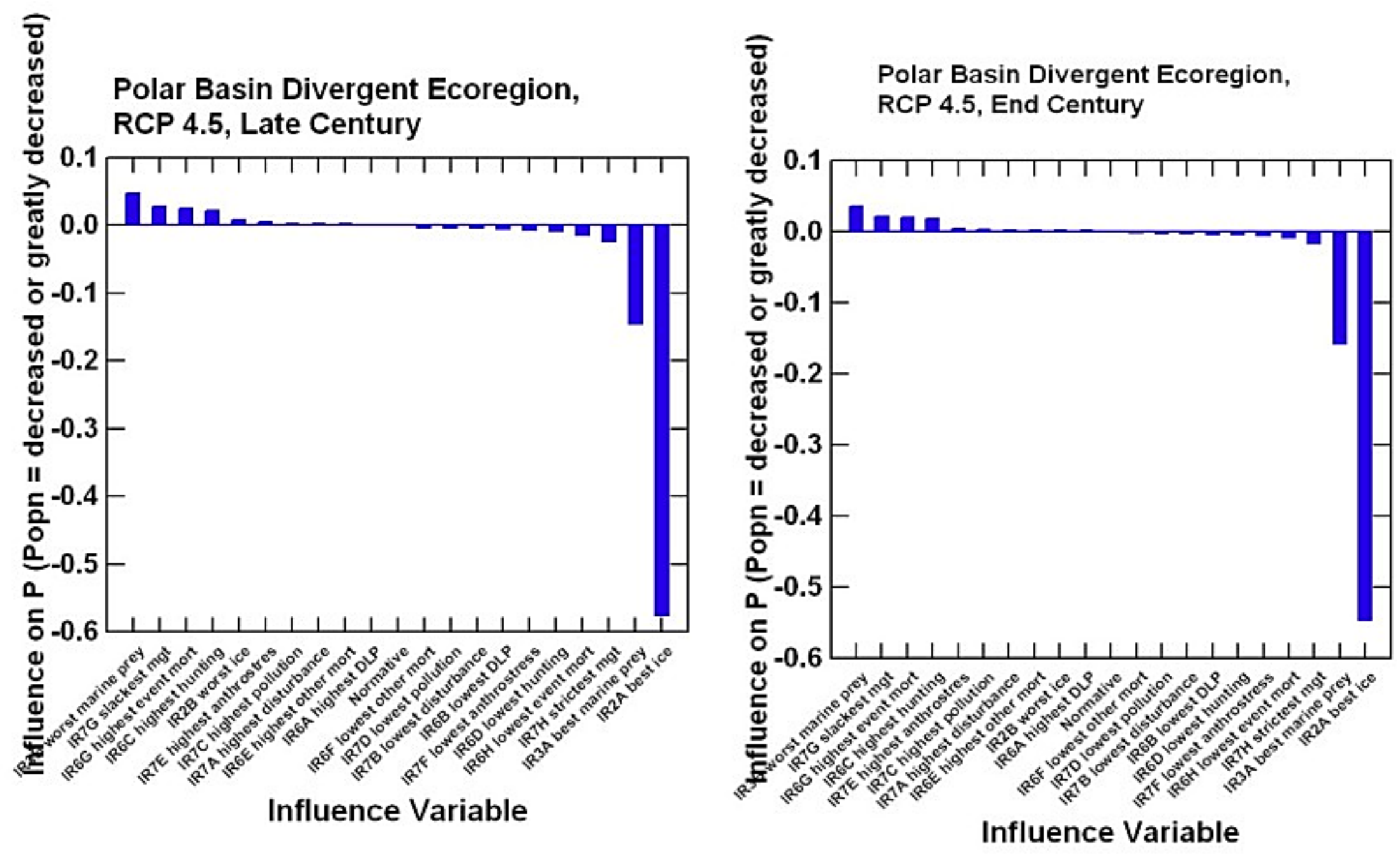

Figure F.1a. Polar Basin Divergent Ecoregion, RCP 4.5.-Continued 

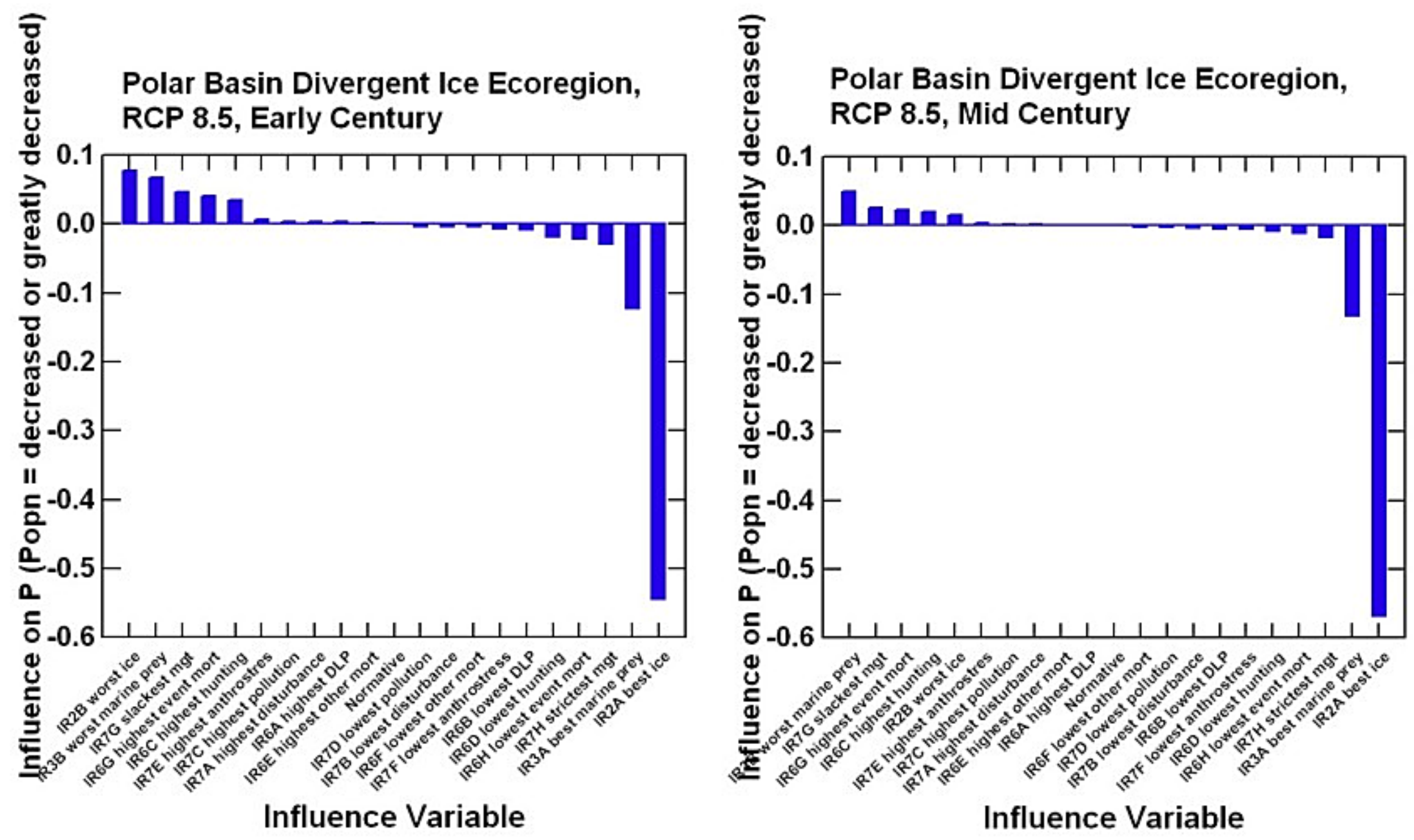

Figure F.1b. Polar Basin Divergent Ecoregion, RCP 8.5. 

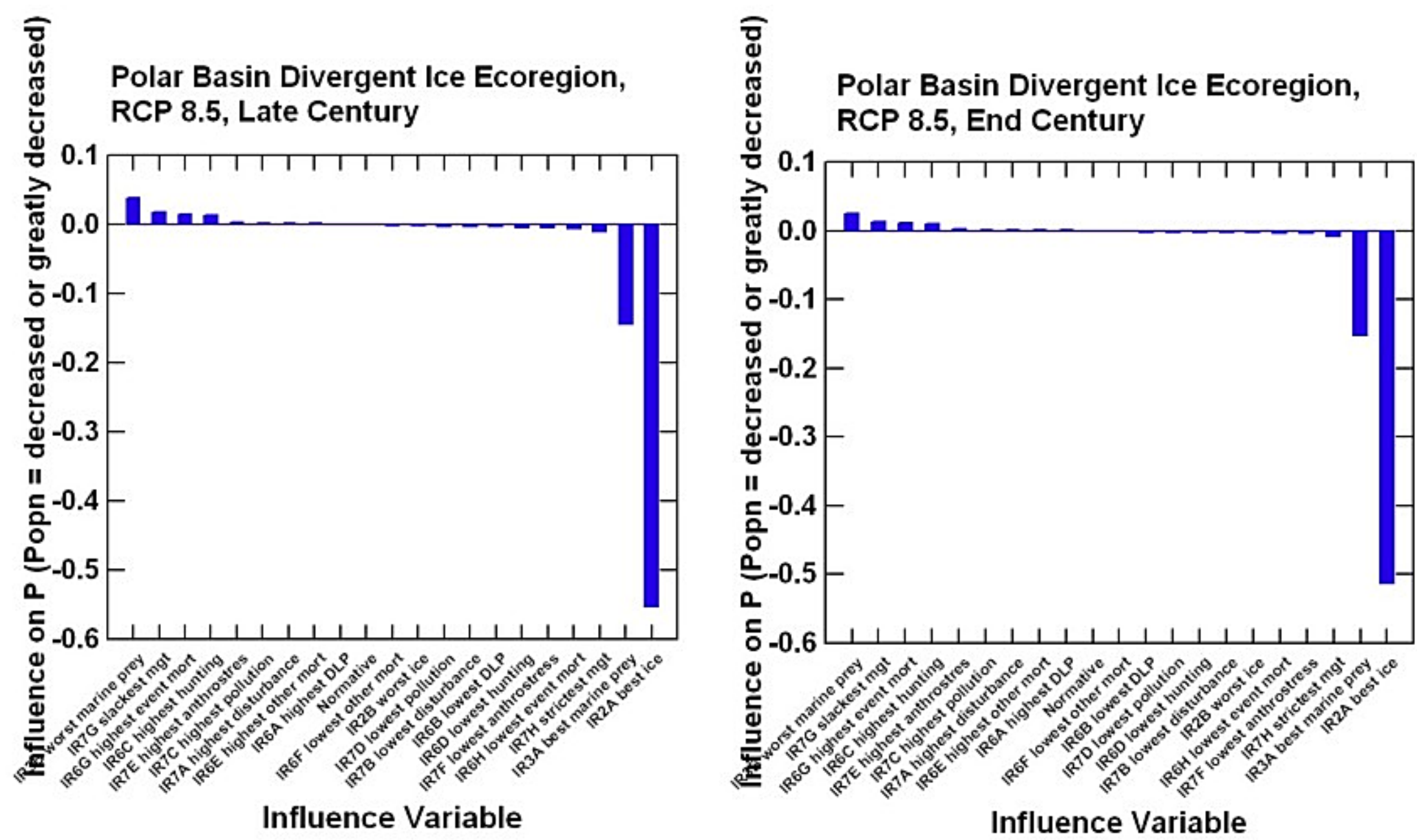

Figure F.1b. Polar Basin Divergent Ecoregion, RCP 8.5.-Continued 

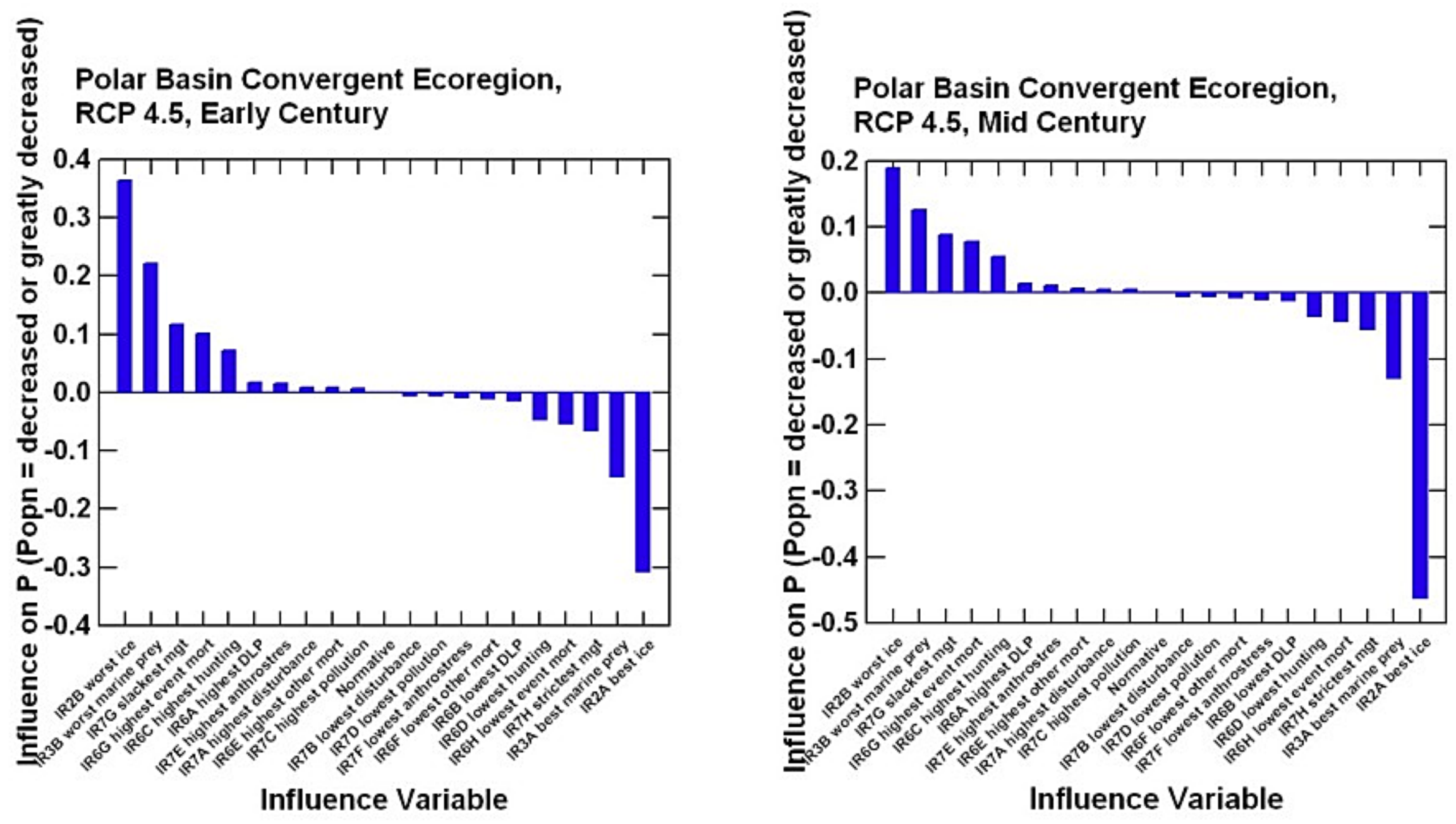

Figure F.2b. Polar Basin Convergent Ecoregion, RCP 4.5. 

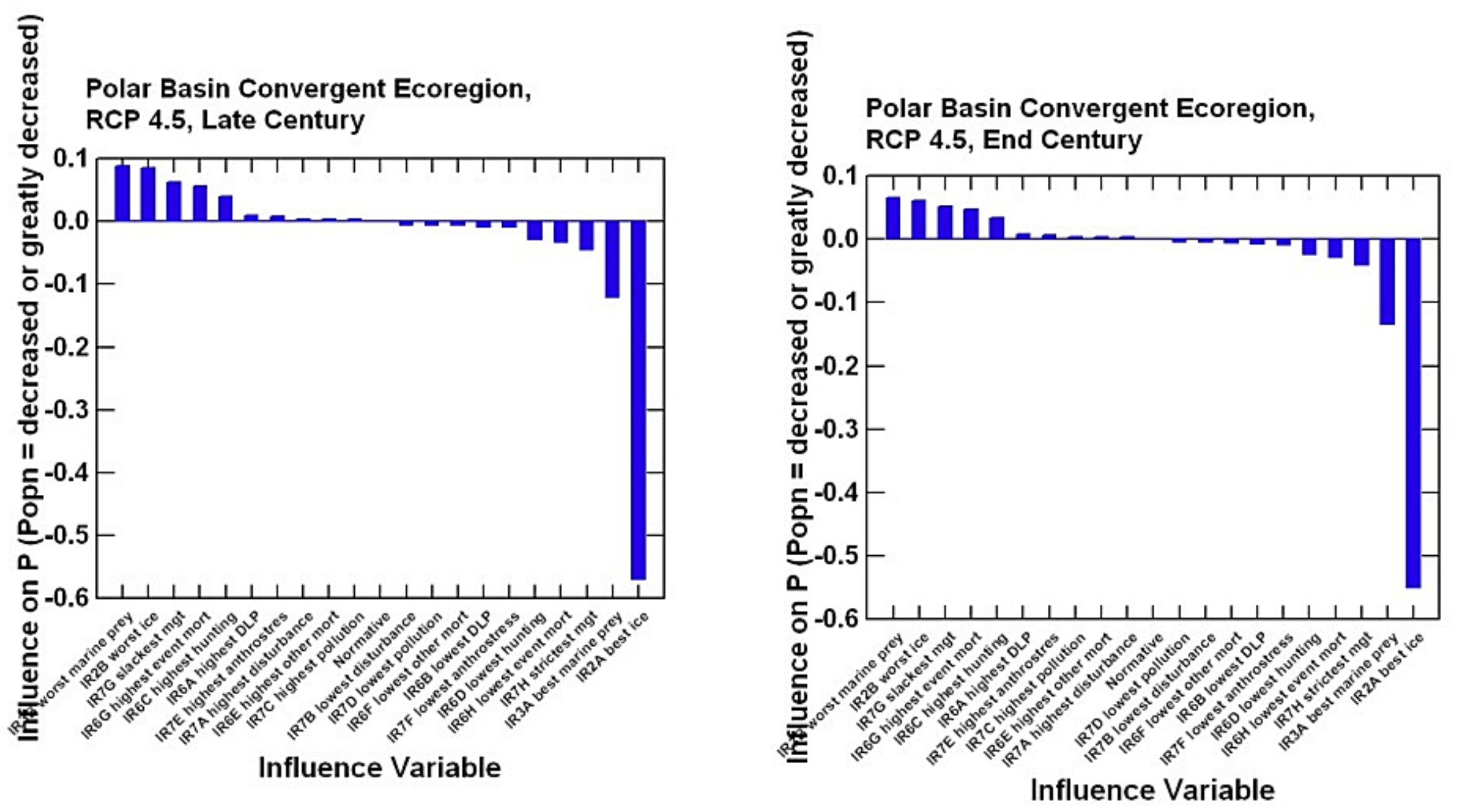

Figure F.2b. Polar Basin Convergent Ecoregion, RCP 4.5.-Continued 

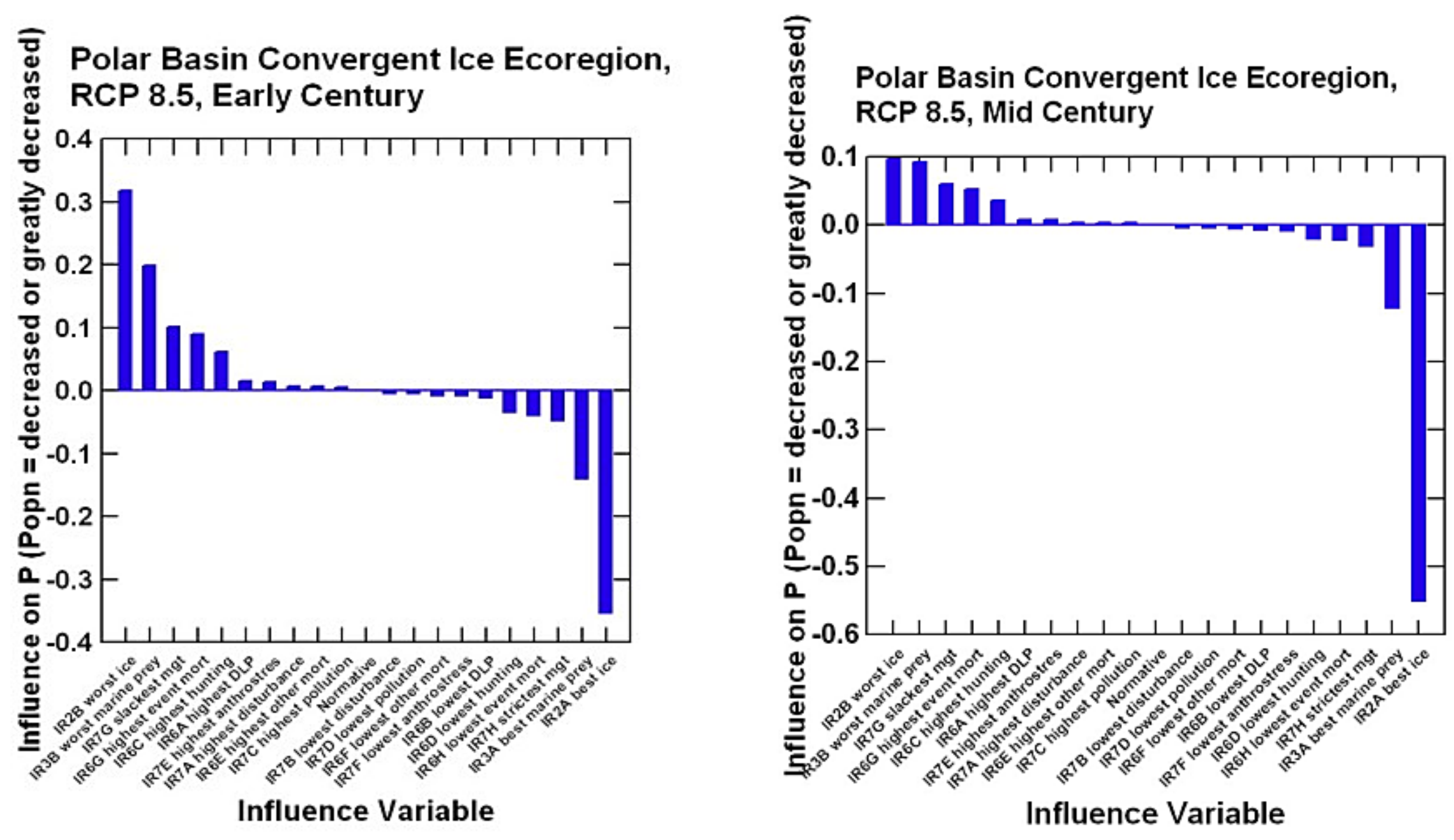

Figure F.2b. Polar Basin Convergent Ecoregion, RCP 8.5. 

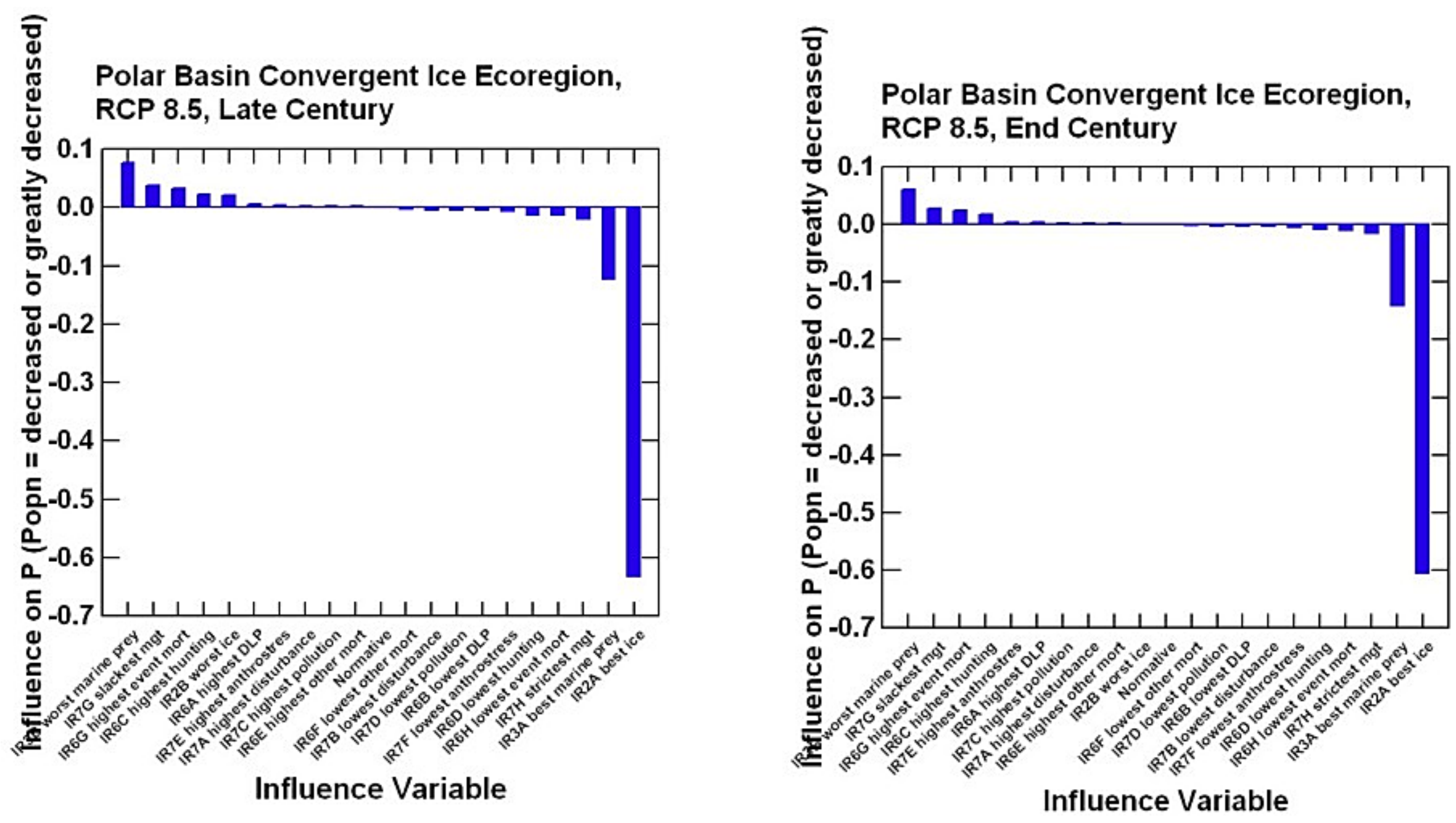

Figure F.2b. Polar Basin Convergent Ecoregion, RCP 8.5.-Continued 

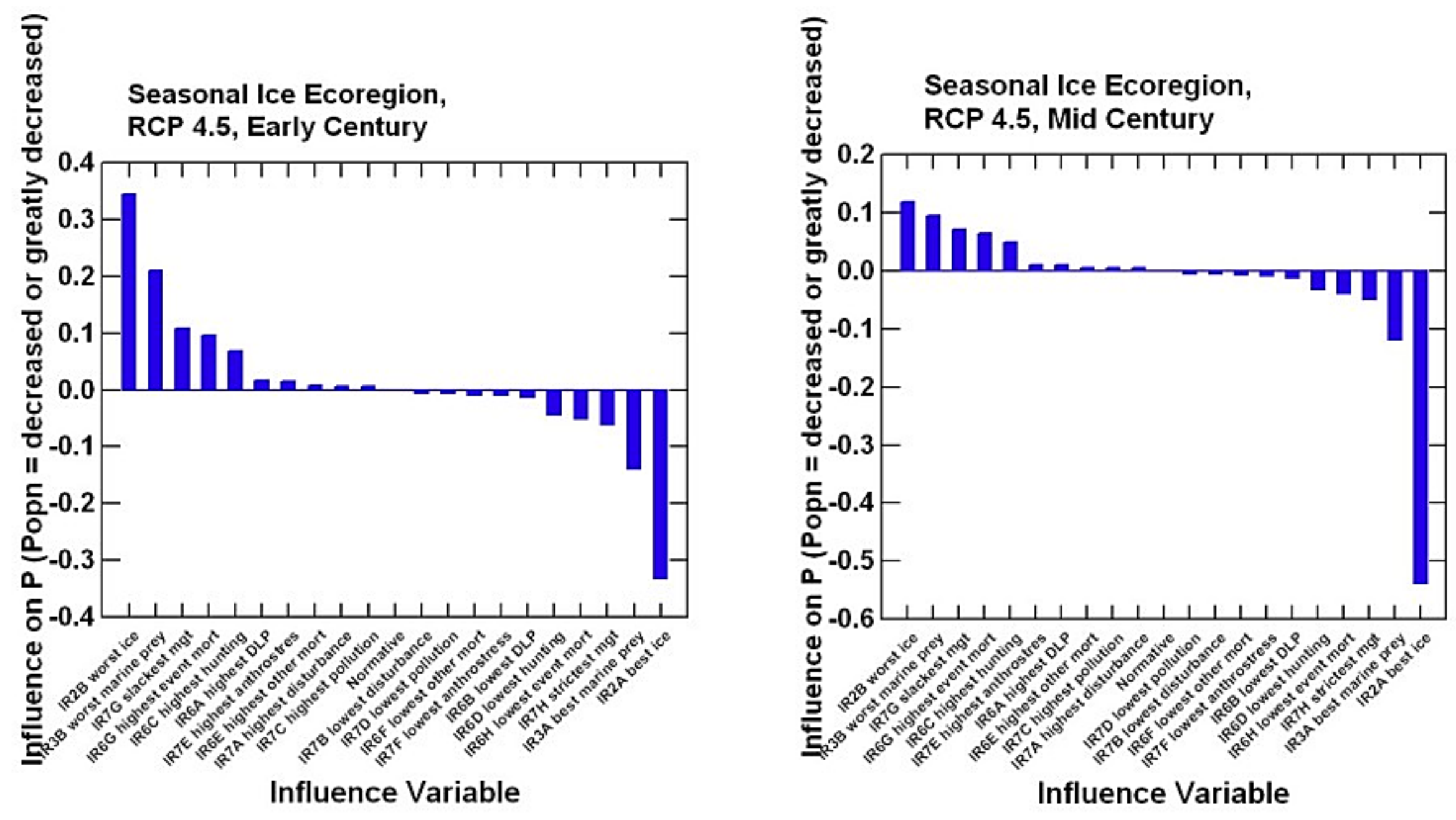

Figure F.3a. Seasonal Ice Ecoregion 4.5. 

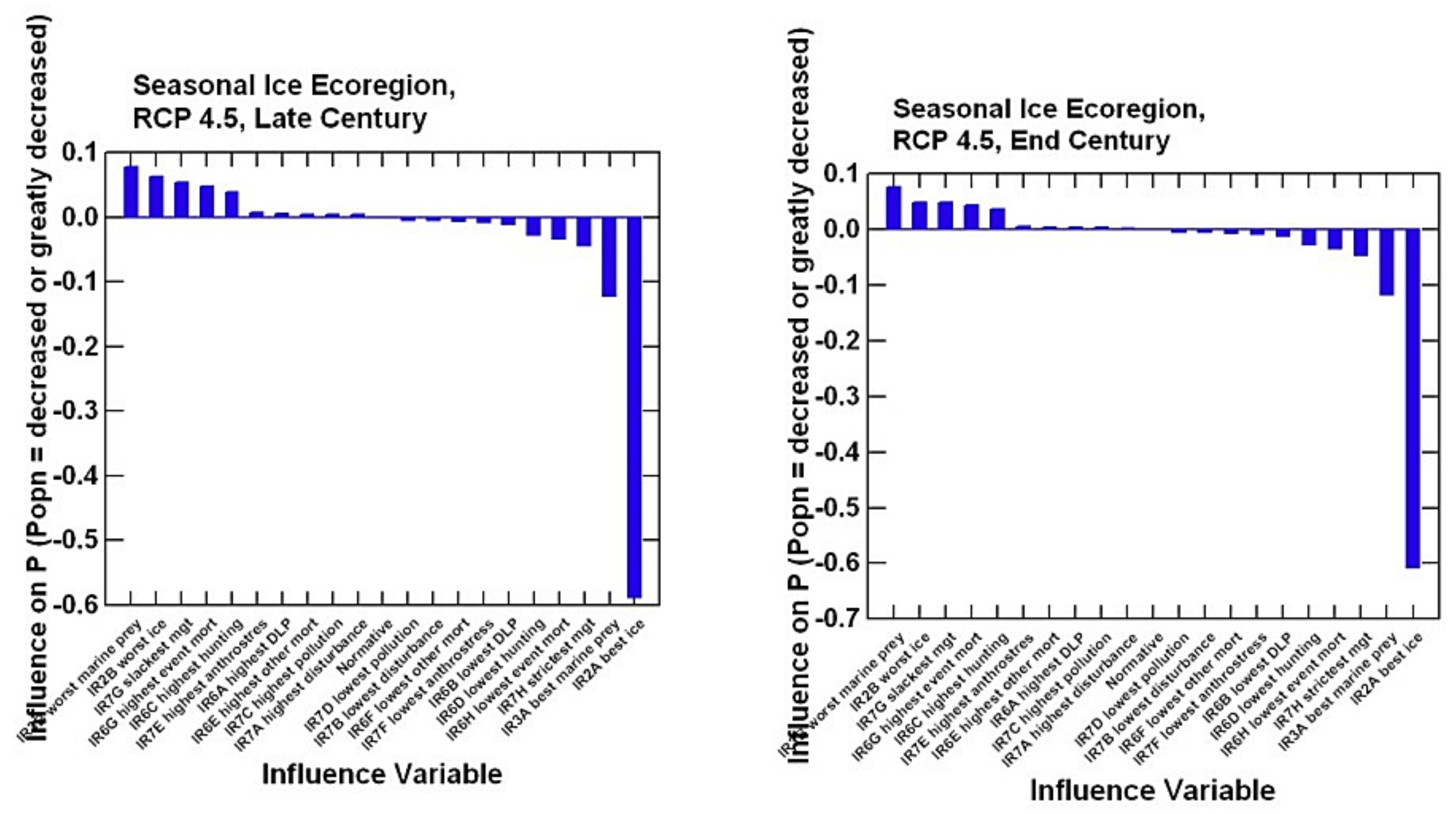

Figure F.3a. Seasonal Ice Ecoregion 4.5.-Continued 

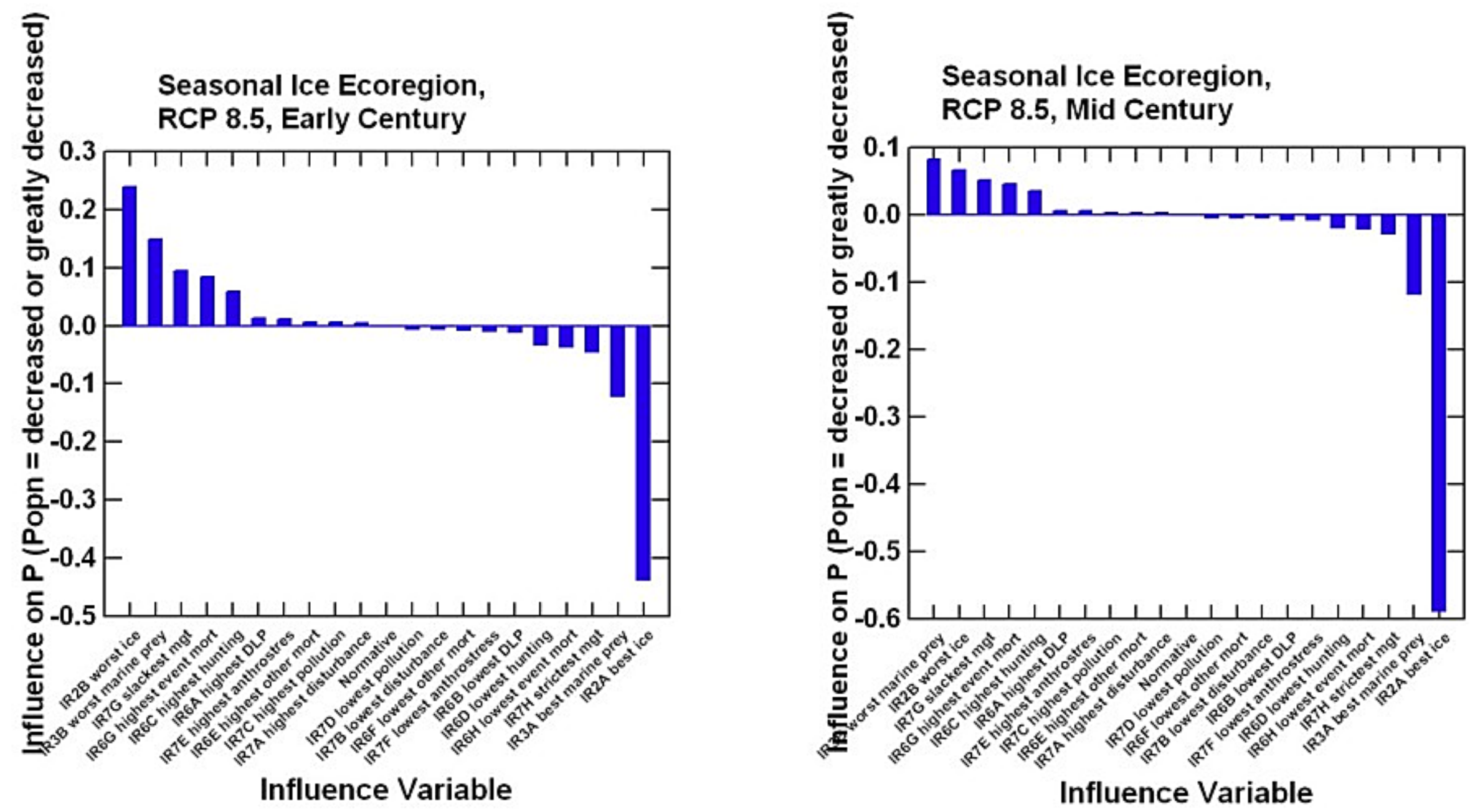

Figure F.3b. Seasonal Ice Ecoregion 8.5. 

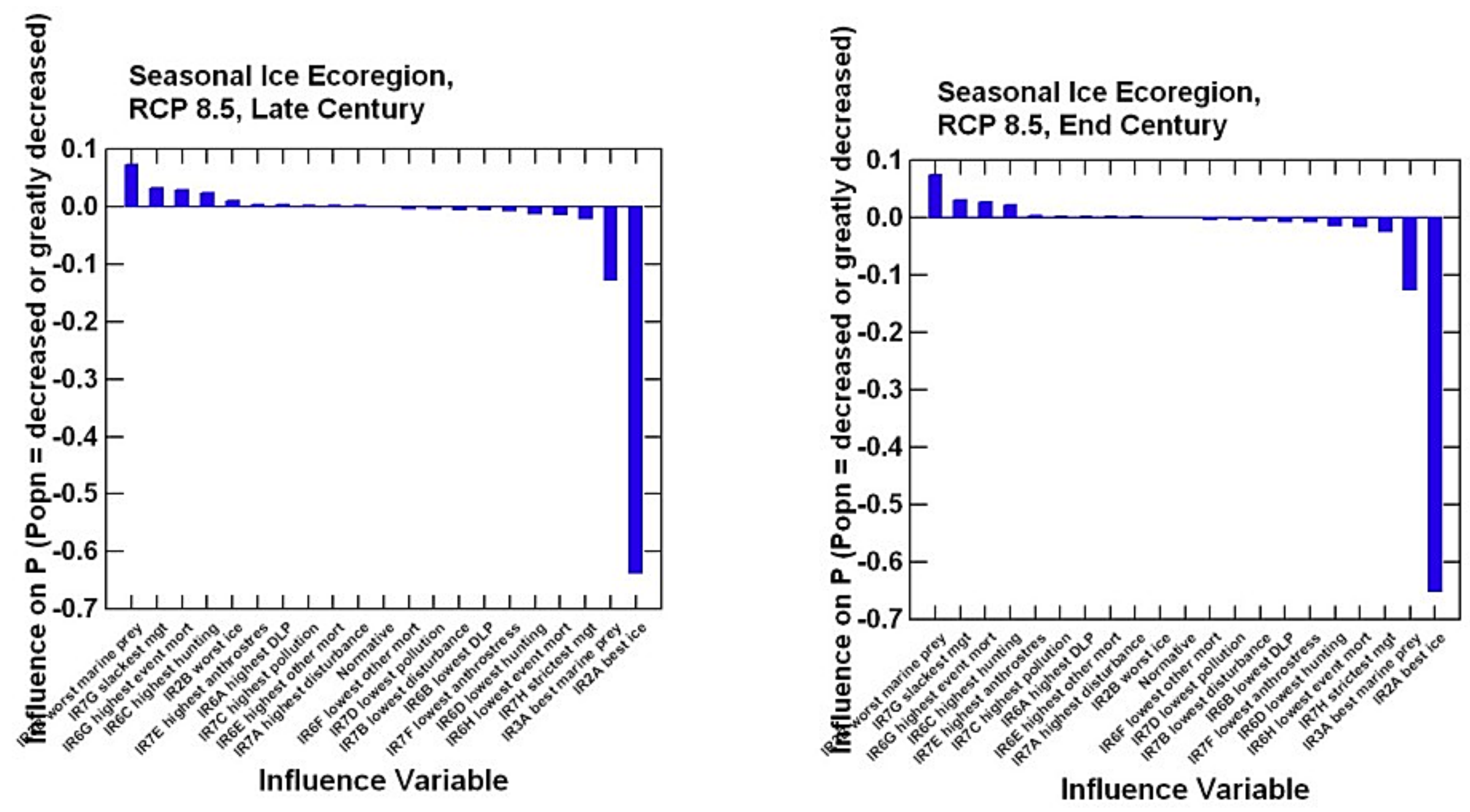

Figure F.3b. Seasonal Ice Ecoregion 8.5.-Continued 


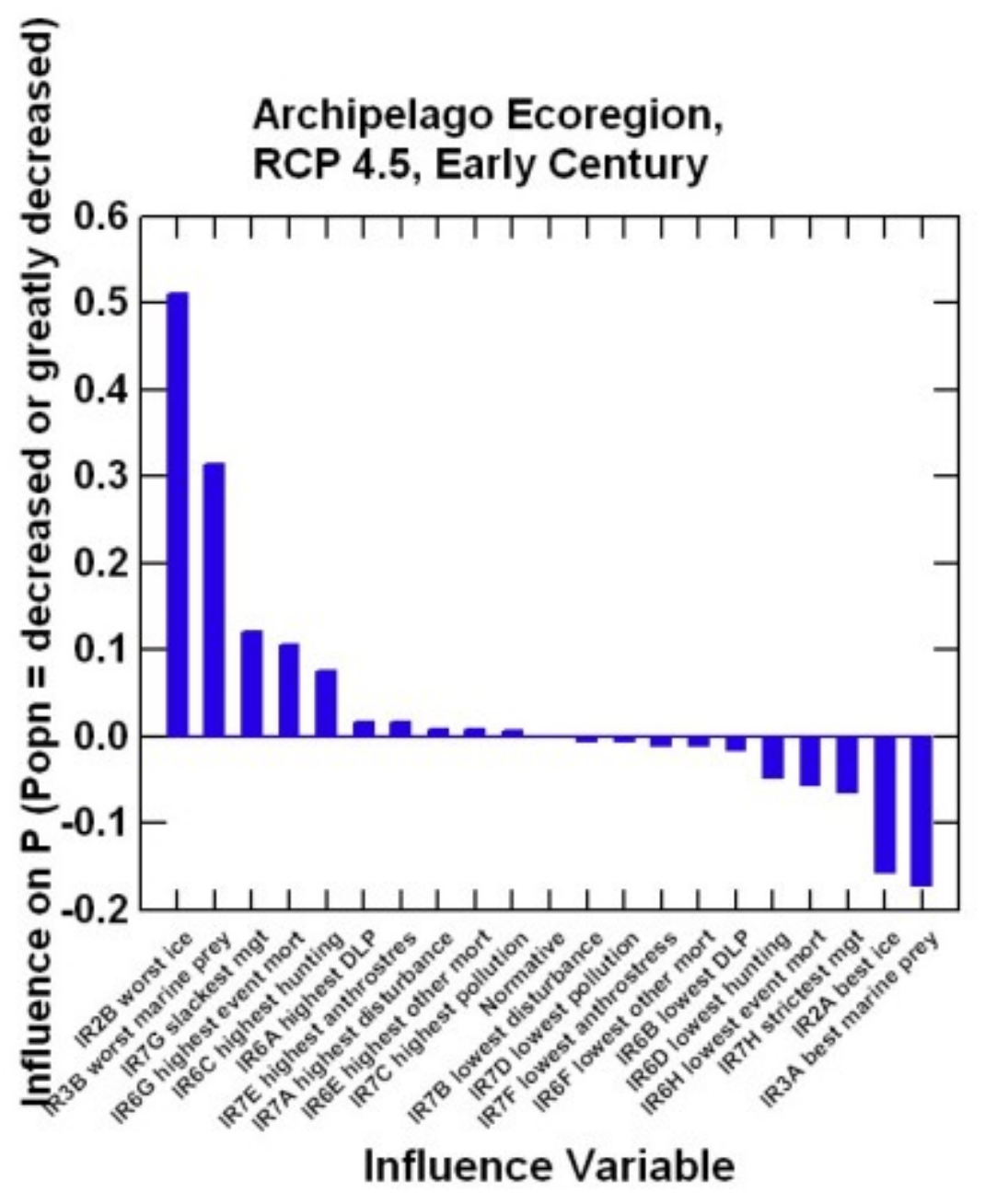

Figure F.4a. Archipelago Ecoregion, RCP 4.5.

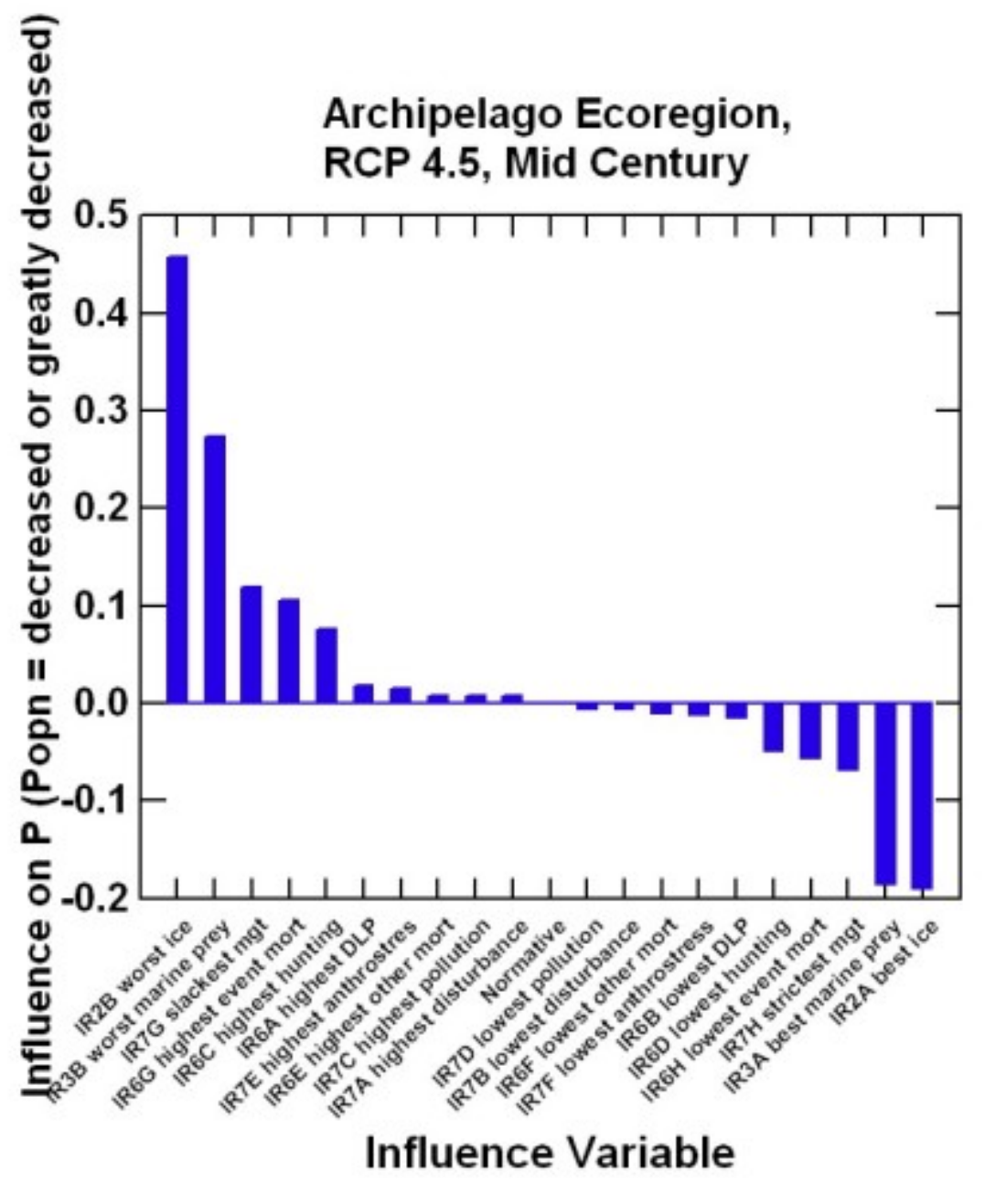



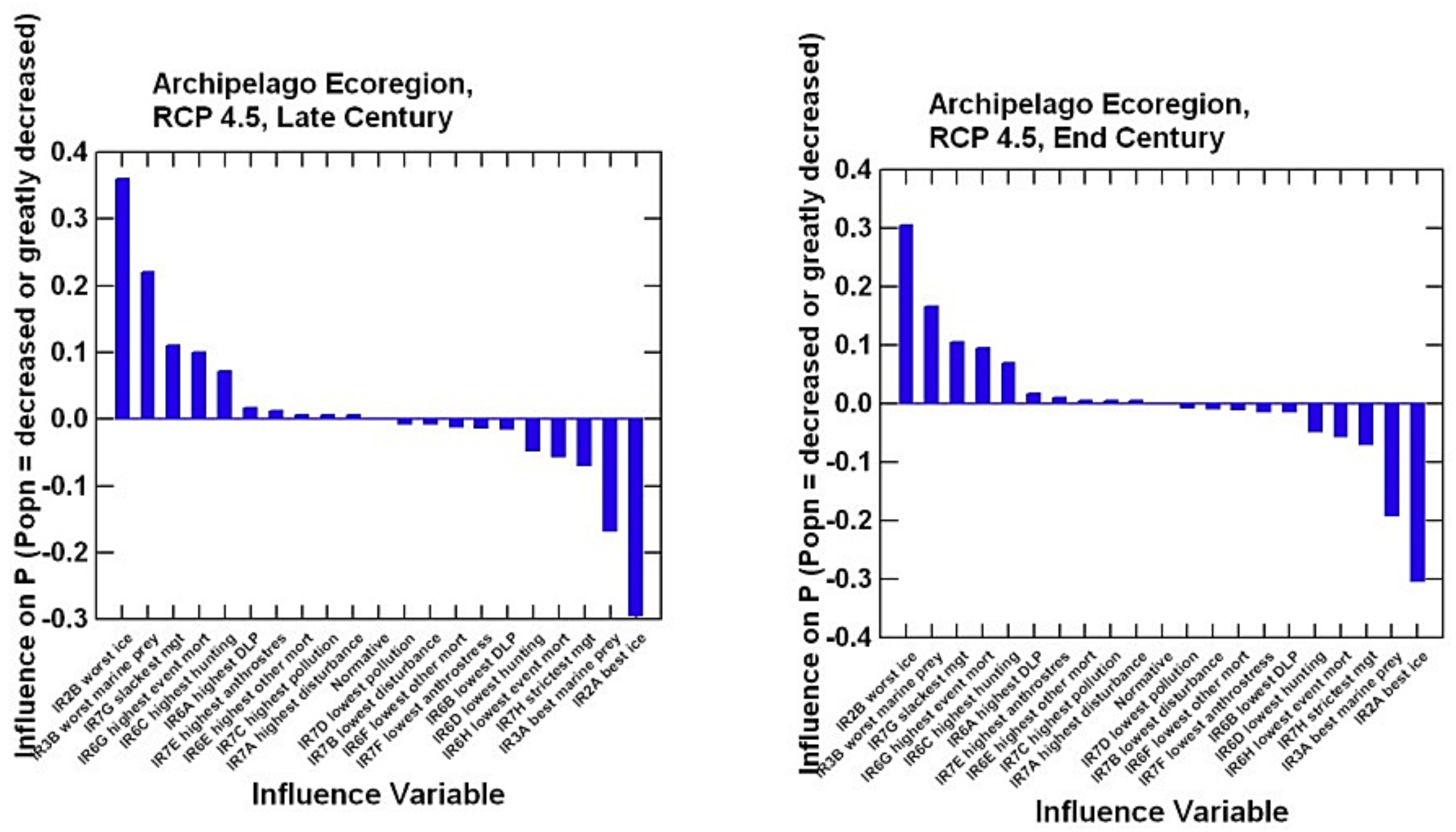

Figure F.4a. Archipelago Ecoregion, RCP 4.5.-Continued 

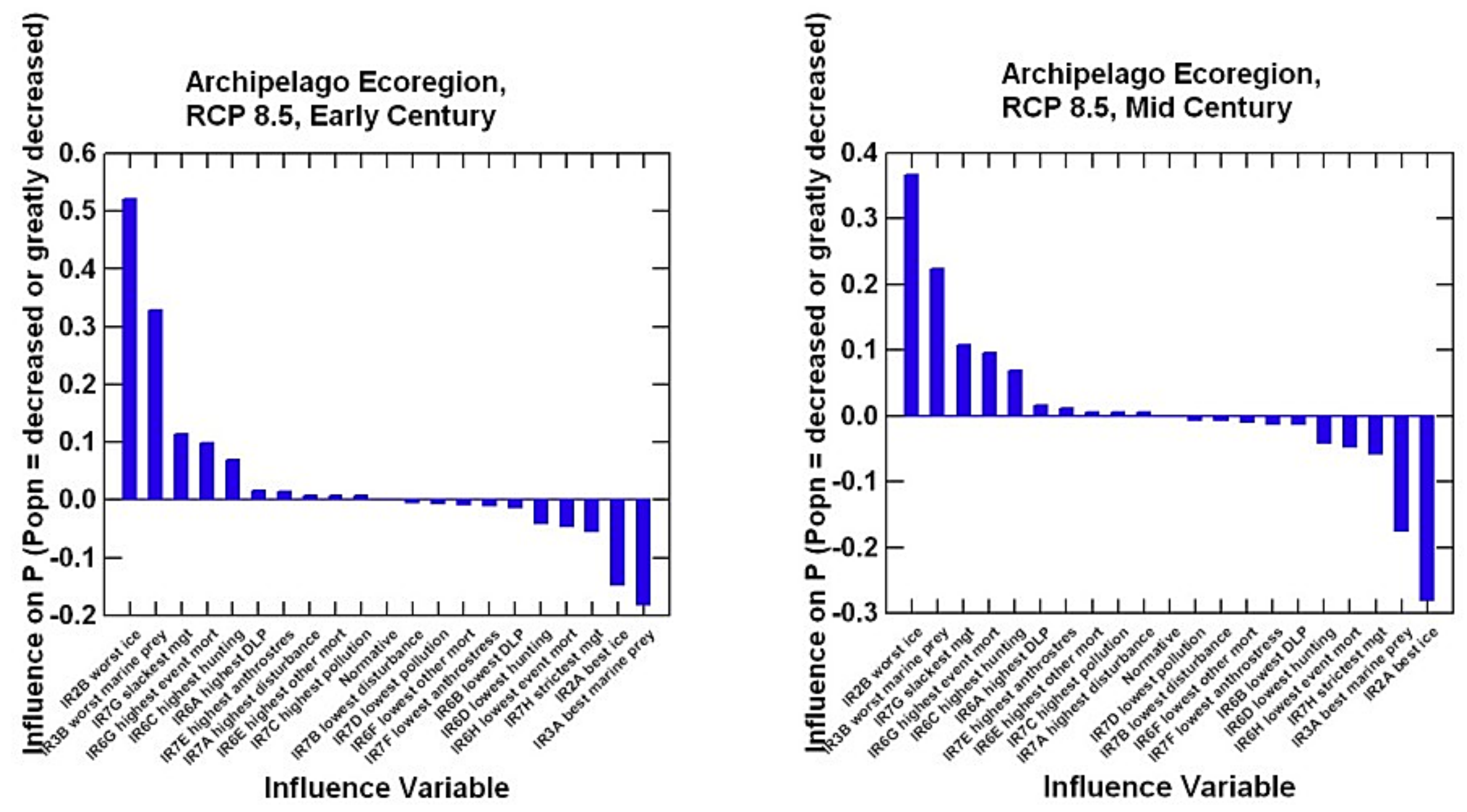

Figure F.4b. Archipelago Ecoregion, RCP 8.5. 

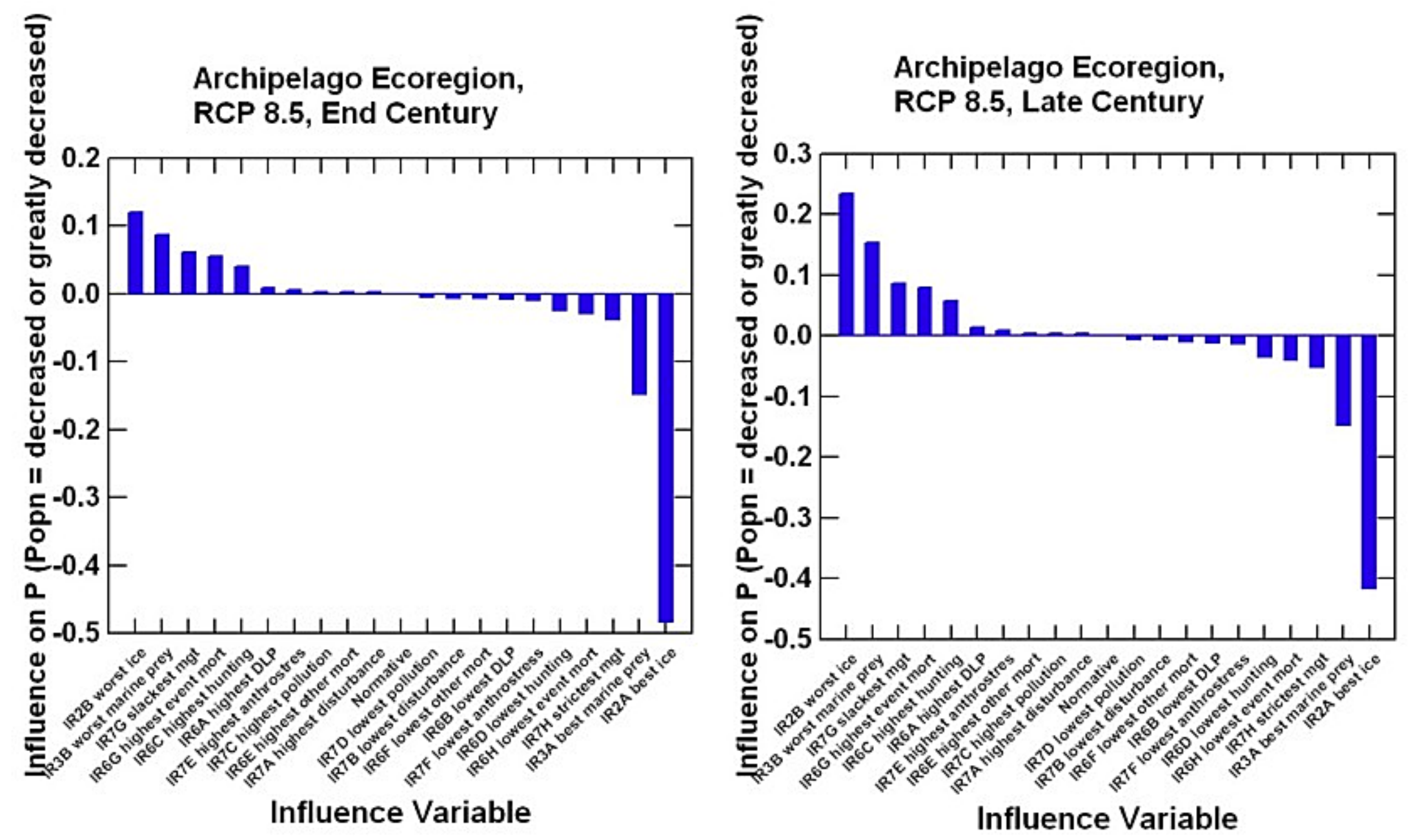

Figure F.4b. Archipelago Ecoregion, RCP 8.5.-Continued 
Publishing support provided by the U.S. Geological Survey Publishing Network, Tacoma Publishing Service Center

For more information concerning the research in this report, contact the Director, Alaska Science Center

U.S. Geological Survey

4210 University $\mathrm{Dr}$

Anchorage, Alaska 99508-4560

http://alaska.usgs.gov 


\section{尊}

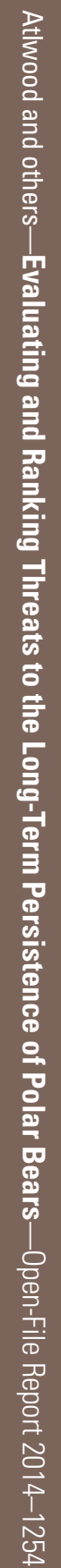

